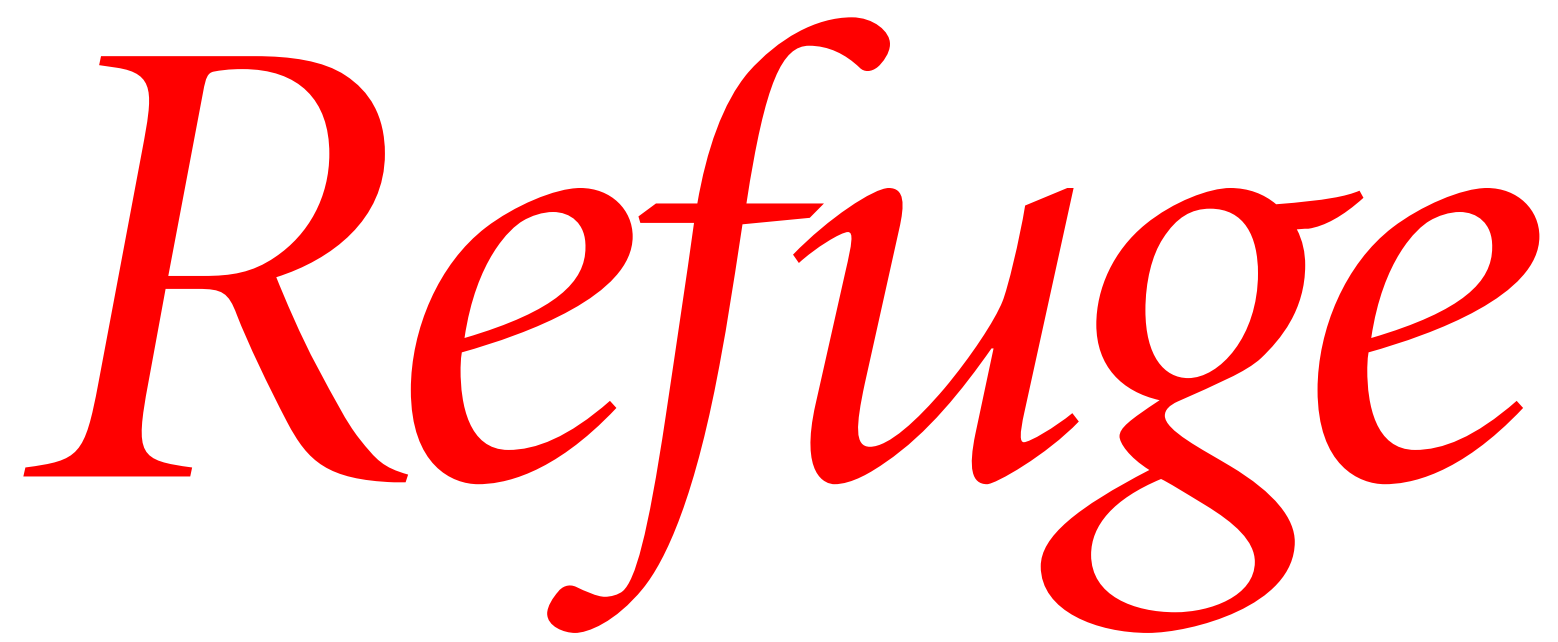

VOL 31 - NO 2 REVUE CANADIENNE SUR LES RÉFUGIÉS

Recognizing and Confronting State Subjectivity in Asylum Adjudications

EMILY C. BARRY-MURPHY AND MAX O. STEPHENSON JR.

"We Are in the Middle of Two Great Powers":

Refugees, Activists, and Government during the Plattsburgh Border Crisis of 1987

JOHN ROSINBUM

The Psycho-Social Conditions of Asylum-Seekers from Darfur in Israel

VERED SLONIM-NEVO, SHIRLEY REGEV, AND YIFTACH MILLO

Forced Displacement and the Crisis of Citizenship in Africa's Great Lakes Region:

Rethinking Refugee Protection and Durable Solutions

LUCY HOVIL AND ZACHARY A. LOMO

Fear and (In)Security: The Canadian Government's Response to the Chilean Refugees

SUHA DIAB

Invisible Lives and Hidden Realities of Undocumented Youth

FARIA KAMAL AND KYLE D. KILLIAN

Navigating Civil War through Youth Migration, Education, and Family Separation

ADRIAN A. KHAN AND JENNIFER HYNDMAN

Leaving Care: Unaccompanied Asylum-Seeking Young Afghans Facing Return

KIM ROBINSON AND LUCY WILLIAMS 


\section{Refuge}

\section{Canada's Journal on Refugees \\ Revue canadienne sur les réfugiés}

Vol. 31, No. 2

Centre for Refugee Studies, Room 844, Kaneff Tower, York University 4700 Keele Street, Toronto, Ontario, Canada M3J 1P3

E-mail: refuge@yorku.ca

Website: http://www.yorku.ca/refuge

\section{Editor-in-Chief}

Christina Clark-Kazak

Managing Editor Nausheen Quayyum

Book Review Editor Dianna Shandy

Editorial Advisory Board

Sharryn Aiken, Queen's University

Laura Bisaillon, University of Toronto Scarborough

Megan Bradley, McGill University

François Crépeau, McGill University

Jeff Crisp, Refugees International

Judith Kumin, University of New Hampshire, Manchester

Susan McGrath, York University

Volker Türk, UNHCR

Madine Vanderplaat, Saint Mary's University

Founded in 1981, Refuge is an interdisciplinary journal published by the Centre for Refugee Studies, York University. The journal aims to provide a forum for discussion and critical reflection on refugee and forced migration issues.

Refuge invites contributions from researchers, practitioners, and policy makers with national, international, or comparative perspectives. Special, thematic issues address the broad scope of the journal's mandate, featuring articles and reports, shorter commentaries, and book reviews. All submissions to Refuge are subject to double-blinded peer review. Articles are accepted in either English or French.

Refuge is a non-profit, independent periodical funded by the Social Sciences and Humanities Research Council of Canada and supported by the membership of the Canadian Association for Refugee Studies (CARFMS). The views expressed in Refuge do not necessarily reflect those of its funders or editors.

Refuge is indexed and abstracted in the Index to Canadian Legal Literature, Pais International, Sociological Abstracts, the International Bibliography of the Social Sciences, and Canadian Business and Current Affairs. In accordance with the journal's open access policy, the full text of articles published in Refuge is also available online through our website, www.yorku.ca/refuge.

ISSN (online): 1920-7336

(C) Author(s), 2015. This open-access work is licensed under a

Creative Commons Attribution-NonCommercial 4.0 International license.
Cette oeuvre en libre accès fait l'object d'une licence Creative Commons Attribution-NonCommercial 4.0 International. 


\section{Contents}

\section{Articles}

Recognizing and Confronting State Subjectivity in

Asylum Adjudications

EMILY C. BARRY-MURPHY

MAX O. STEPHENSON JR.

"We Are in the Middle of Two Great Powers":

Refugees, Activists, and Government during the

Plattsburgh Border Crisis of 1987

JOHN ROSINBUM .......................... 15

The Psycho-Social Conditions of Asylum-Seekers

from Darfur in Israel

VERED SLONIM-NEVO

SHIRLEY REGEV

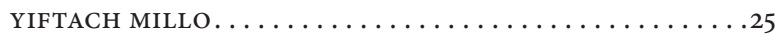

Forced Displacement and the

Crisis of Citizenship in Africa's Great Lakes Region:

Rethinking Refugee Protection and Durable Solutions LUCY HOVIL

ZACHARY A. LOMO $\ldots \ldots \ldots \ldots \ldots \ldots \ldots \ldots \ldots \ldots, \ldots \ldots$

Fear and (In)Security: The Canadian Government's

Response to the Chilean Refugees

SUHA DIAB............................

Invisible Lives and Hidden Realities of

Undocumented Youth

FARIA KAMAL

KYLE D. KILLIAN

Navigating Civil War through Youth Migration,

Education, and Family Separation

ADRIAN A. KHAN

JENNIFER HYNDMAN

Leaving Care: Unaccompanied Asylum-Seeking

Young Afghans Facing Return

KIM ROBINSON

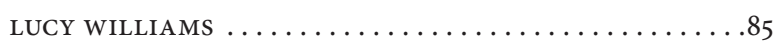

\section{BOOK REVIEWS}

Adjudicating Refugee and Asylum Status:

The Role of Witness, Expertise and Testimony

edited by Benjamin N. Lawrance and Galya Ruffer

GRAEME RODGERS ........................ 95

Migrant Women of Johannesburg:

Life in an In-Between City

by Caroline Wanjiku Kihato

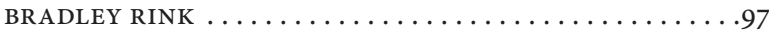

Belonging: The Social Dynamics of Fitting In

as Experienced by Hmong Refugees,

in Germany and Texas

by Faith G. Nibbs

KATHLEEN A. CULHANE-PERA $\ldots \ldots \ldots \ldots \ldots \ldots 98$

The Law of Refugee Status, 2nd edition

by James C. Hathaway and Michelle Foster

DOUGLAS CANNON ..........................

Survival Migration: Failed Governance

and the Crisis of Displacement

by Alexander Betts

Humanitarian Crises and Migration:

Causes, Consequences and Responses

edited by Susan F. Martin, Sanjula Weerasinghe,

and Abbie Taylor

Crisis and Migration: Critical Perspectives

edited by Anna Lindley

JAMES MILNER. . . . . . . . . . . . . . . . . . . . . . . 101
(C) Author(s), 2015. This open-access work is licensed under a

Creative Commons Attribution-NonCommercial 4.0 International license.
Cette oeuvre en libre accès fait l'object d'une licence Creative Commons Attribution-NonCommercial 4.0 International. 
(C) Author(s), 2015. This open-access work is licensed under a Creative Commons Attribution-NonCommercial 4.0 International license.
Cette oeuvre en libre accès fait l'object d'une licence Creative Commons Attribution-NonCommercial 4.0 International. 


\title{
Recognizing and Confronting State Subjectivity in Asylum Adjudications
}

\author{
EMILY C. BARRY-MURPHY AND MAX O. STEPHENSON JR.
}

\begin{abstract}
United States law charges America's asylum officers with providing humanitarian protection for refugees while simultaneously securing the nation from external threats. This mandate requires that asylum officers balance potentially conflicting claims as they seek to ensure just treatment of claimants. This article explores how officers charged with that responsibility can develop a regime-centred subjectivity that often conditions them to view applicants with fraud and security concerns foremost in mind. This analysis also examines the potential efficacy of practical strategies linked to aesthetic, cognitive, affective, and moral imagination that may allow officials to become more aware of their statecentred subjectivity and how it influences their perceptions of threats to national security and to fraud. This analysis encourages adjudication officers to strive for a more nuanced understanding of what constitutes fraud and national security concerns and what are instead presuppositions created by the United States population-protection agenda.
\end{abstract}

\section{Résumé}

La loi aux États-Unis investit les agents préposés aux demandes d'asile avec la responsabilité d'accorder la protection humanitaire aux réfugiés et en même temps de protéger le pays des dangers venant de l'extérieur. Un tel mandat nécessite que les agents réconcilient des exigences potentiellement conflictuelles tout en assurant un traitement équitable des demandeurs. Cet article étudie le processus selon lequel les agents chargés de cette responsabilité peuvent développer une subjectivité axée sur le régime qui les conditionne souvent à voir les demandeurs dans une perspective privilégiant la sécurité et la fraude. Également, cette analyse examine l'efficacité potentielle de stratégies pratiques liées à l'imagination esthétique, cognitive, affective, et morale qui pourraient rendre les agents plus conscients de leur subjectivité axée sur l'état et comment elle influe sur leurs perceptions de ce qui constitue un danger pour la sécurité nationale et un risque de fraude.

\section{Introduction}

T Thited States law mandates that America's asylum officers provide humanitarian protection for refugees and secure the nation from external threats. This charge requires these individuals, including the lead author of this article, who work for the United States Citizenship and Immigration Services (UsCis), to balance potentially conflicting claims as they seek to ensure just treatment of claimants, many of whom have fled terrible conditions, while also protecting the United States from fraud and security threats. Asylum officers determine whether the facts of applicants' cases justify classifying them as refugees under United States law. United States asylum law is derived in part from international accords that include the 1951 Refugee Convention Relating to the Status of Refugees and the 1967 Protocol that extended both the temporal and geographic understanding of "refugee" among nations. ${ }^{1}$ The U.S. Immigration and Nationality Act (INA) defines a refugee as an individual who has experienced persecution or has a well-founded fear of ill-treatment on account of a protected ground of political opinion, race, religion, nationality, or membership in a particular social group. The INA also provides the Department of Homeland Security authority to determine whether alien individuals meet this definition.

uscis has many systems to ensure that officials accurately classify applicants and perform legally sufficient refugee
(C) Author(s), 2015. This open-access work is licensed under a

Creative Commons Attribution-NonCommercial 4.0 International license.
Cette oeuvre en libre accès fait l'object d'une licence Creative Commons Attribution-NonCommercial 4.0 International. 
determinations. For example, asylum officers complete several weeks of residential training and four hours per week of continuing education on how to interpret relevant U.S. law. Administrators learn how to conduct thorough national security and fraud checks, who can be considered a refugee as well as how to process applications for so-called affirmative and defensive asylum applicants. In addition, a supervisor reviews every adjudication decision reached by an asylum official, and, in many cases, quality assurance specialists and/or second, third, and fourth reviewers may evaluate a decision as well. Asylum officers undergo extensive training in legal standards of interpretation, psychological understanding of trauma victims, and sociological sensitivity to gender and culture. The goal of all these efforts is to guarantee that those qualifying are granted protection, while those pressing fraudulent claims or who constitute a threat to national security are denied that standing. Uscis officials are government employees, and their adjudication of refugee narratives occurs under the aegis of the regime. In consequence, how these individuals conceptualize their relationship with the state often remains hidden, despite the fact that "power and politics are inseparable from the process of social construction that creates refugee systems."2 As such, it is important to explore how refugee officials exercise state power and, in particular, to investigate how political forces may condition asylum determinations. As a result, it is useful to examine practices that asylum officers could employ to recognize and counter their state subjectivity.

\section{State Sovereignty in Asylum Adjudication}

A national approach to refugee protection through asylum makes the state invisible in that decision. That is, the government's role in deciding the criteria on which asylum will be predicated is rarely questioned thereafter by those involved in refugee protection. As Beck has argued, "Methodological nationalism assumes that nation, state and society are 'natural' social and political forms of the modern world. It assumes a 'natural' division of humanity into a limited number of nations that organize themselves from within and demarcate themselves externally by drawing boundaries between themselves and other nations."3

He has contended that this assumption affects the ways in which individuals collect, interpret, and generate concepts and has challenged analysts to work outside this perspective to remain mindful that all regime processes are political and socially constructed. Viewing the individual asylum officer within the context of his or her position as state agent allows scholars to consider how these individuals are enmeshed in regime politics and "regain sovereignty and the ability to shape events through the nation state system."4
Weber's work concerning "simulating sovereignty" is useful when examining how asylum decision-makers regain/gain sovereignty in this sense. 5 Weber has employed Foucault to contend "that some foundational truth underwrites a particular organization of knowledge and that truth is not opposed to but is an effect of power." She questions how "a search for meaning diverts attention from the production of meaning ... in other words, [Weber raises the question of whether] interpretive communities [are] effects of discourses of truth and the workings of power."7 Foucault posited that individuals enact certain discourses to represent state interests. ${ }^{8}$ Likewise, as asylum officers focus on the facts of cases to determine whether an individual fits the statutory definition of a refugee, their attention can be diverted from the state-centred power dynamics that influence how that understanding was produced.

Weber turned to Baudrillard to explore embedded, simulated constructions of the state. ${ }^{9}$ She argued that the referent to which Foucault pointed is itself a constructed subject and that the state, the authoritative or represented power, is therefore simulated, because it cannot be a referent of itself. That is, Weber has contended the state and state boundaries constitute ideologies. Following this argument, one may suggest that as United States asylum officers listen to narratives and decide who qualifies as a refugee, they represent not just state power, but also a process of simulation of the self as state, and the petitioner as an "other" outside the regime.

Legitimation is key to Weber's theory of simulating sovereignty. She has suggested that individuals normalize their understanding of the state by first determining who is outside the nation's confines. ${ }^{10}$ For the refugee, this occurs through discursive legitimation through simulation. Weber has argued that a domestic community must be differentiated from "other" groups and that disenfranchised individuals, including refugees, are constantly crossing the boundary of who is considered a member of such social constructs. ${ }^{11}$ In this sense, state boundaries, like the distinction one draws between citizens and non-citizens, can be seen as ideological structures. If one accepts Weber's view that nation and state borders are created via regime arbiters who simulate and legitimate the state, one may also ask how this scenario shapes asylum narrative adjudication decisions. As Weber has observed, "Only by maintaining control over the depiction of its people can the state authoritatively claim to be the agent of its people. Without the ability to make credible its claims to both political and symbolic representation, the state risks forfeiting its presumed ability of representation and ultimately its sovereignty." ${ }^{\prime 2}$

The analyst must examine the practices through which asylum officers gain and give power to the state when
(C) Author(s), 2015. This open-access work is licensed under a

Creative Commons Attribution-NonCommercial 4.0 International license.
Cette oeuvre en libre accès fait l'object d'une licence Creative Commons Attribution-NonCommercial 4.0 International. 
applying Weber's logic to adjudications. This in turn involves investigating how these officials make decisions and how they legitimate themselves by allying their choices with representations of the state ideal and how that inclination affects their evaluations of asylum applications and narratives.

\section{The Ethos, Pathos, and Logos of "Simulating" the State}

Since asylum represents a metaphoric and legal unification with the state, identifying the avenues through which officials embody and perpetuate the regime when making this decision is important. For the same reason, it is helpful to illuminate steps that officers can take to dignify and respect applicants in that process. The uscis officer constructs and simulates the state and the refugee by deciding which individuals attain protection, and by making decisions that shape policy implementation and influence law. However, asylumseekers are not the only actors discursively constructed in determination. The same is true of those interacting with them. Indeed, the refugee is "produced through a complex process of social construction involving ourselves."13 To influence systems that define asylum recipients depends on "having access to formal authority, control over key resources, or the ability to discursively manage legitimacy." 14 As asylum officers determine the status of refugees, they solidify their own standing as symbolic referents of the state.

An Aristotelian approach to examining how officers claim their standing as state representatives allows the analyst to view that process in terms of ethos, pathos, and logos-based appeals. In a classical Aristotelian argument, the audience is extremely important. A request may fail if spectators do not accept the legitimacy of the individual making a claim (ethos), if the contention is contrary to the beliefs of the audience (pathos), and/or if the onlookers do not accept the reasoning on offer (logos). Viewed this way, asylum officers simulate sovereignty through professionalization (state ethos), morality conditioning (governmental pathos), and legal interpretations (public logos).

The asylum officer simulates herself as the state and is legitimized as a regime arbiter by representing the government ethos. In the process of professionalization as state worker, the official creates a boundary between herself and applicants, even as she represents herself as a sovereign United States decision-maker. Put differently, by professionalizing and following established and purportedly institutionalized and routinized decision criteria, asylum officers "become" the state.

Professionalization begins even before the officer is offered a position, when she prepares herself with a graduate or law degree, fine-tunes social skills and organizational ability, and learns how to work within a bureaucratic structure. To attain a government post, individuals must fit the mould of a successful asylum officer. By obtaining a position as such, an official becomes a market success, as revealed by financial compensation, stable work, benefits, and opportunities for career progression. Officers adopt additional symbols of professionalization to adhere to state ethos, such as wearing a badge that signals authority and security clearance.

In addition to these physical manifestations of professionalization, asylum officials learn to navigate the U.S. government's linguistic environment. For example, they master the language of the acronym: "PSG cases" (particular social group-a specific category of individuals that can be protected under United States law), "RAIO” (refugee, asylum, and international operations - the home of the Asylum Division within USCIS), and "CAT claims" (Convention against Torture-referring to a specific type of applicant assertion). Officers must also become familiar with the agency's governance structure. Professionalization legitimizes the individual as a power-holding government official. All of these capacities are simulations of state power that separate asylum-seekers and officers.

Asylum officers also simulate sovereignty and legitimize themselves as government arbiters by representing regime pathos. In doing so, they adopt a moral stance matching their employer's (the nation's) definition of refugee protection and of state authority within such decision-making. Officials learn to view themselves as insurers of refugee protection and of Americans' safety. In some cases, this role may lead officers to define themselves as patriots, demarcating what is moral and immoral in international relations. In one nowinfamous historical incident, the MS St. Louis, a German ocean liner whose captain was seeking refuge for his 937 Jewish passengers, was turned away from the United States in 1939 and sent back to Europe, where more than a quarter of the ship's travellers perished in Nazi concentration camps. Today, that choice seems outrageous, but in 1939, officials made the decision in the name of American state sovereignty. ${ }^{15}$ Often, however, such distinctions and judgments receive little public attention, and yet they are routinely drawn. President Lyndon Johnson, for example, explicitly welcomed asylum seekers from Cuba because U.S. policy-makers then perceived it as a threat to American security. The larger point is that United States leaders have always distinguished among groups when making asylum policy decisions. ${ }^{16}$ And like all policy, these choices are often informed as much by prejudice and prevailing norms as by explicitly articulated criteria. They therefore change as popular sentiments and imaginaries shift.

During training, officers learn from torture survivors and also learn instances of national security and fraud breaches by unscrupulous applicants. Examples of both
(C) Author(s), 2015. This open-access work is licensed under a

Creative Commons Attribution-NonCommercial 4.0 International license.
Cette oeuvre en libre accès fait l'object d'une licence Creative Commons Attribution-NonCommercial 4.0 International. 
helpless refugees and U.S. citizens harmed by terrorists play on officers' compassion as well as hubris, and together these experiences work to justify their official role as protectors. Assuming the role of guardians of national sovereignty and security in turn "provides [officials] further justification of the determination process" and reinforces a fixed notion of what defines a refugee. ${ }^{17}$

Similarly, asylum officers adhere to state pathos by presupposing the U.S. approach to international politics. USCIS asylum officers use and uphold the United States' causebased approach to refugees. Instead of a cosmopolitan human rights-based method that views fundamental rights as grounds for asylum, the United States upholds a causebased conceptual frame for protection. ${ }^{18}$ This focus can steer asylum officers toward a stance of prosecutors and government guarantors rather than seeking to ensure human rights and dignity for all applicants. So, for example, instead of seeing a fearful unaccompanied minor refugee from Central America as deserving basic human rights and potentially able to benefit from asylum, United States law and practice classify this person, using statist rhetoric, as a potential asylee, but also a possible national security threat. Put differently, national security rhetoric on border protection and transgressors effectively criminalizes defensive-filing applicants, which de facto erodes their basic human rights. ${ }^{19}$

Shemak has explored this tension in U.S. asylum law, and in the asylum officer role, thoughtfully and poignantly. As she has observed, "Asylum speaker testimonies rest upon their perceived truth-value. These testimonies reflect the confrontation between the nation-state and testimonial articulations as they are under constant scrutiny for their credibility, or lack thereof."2o

Even the resources that asylum officers employ as country-condition evidence reflect the government's political agenda. ${ }^{21}$ Asylum decision-makers rely on reports produced by the Department of State and Western organizations to help them make "legally sufficient" decisions, but these analyses are designed foremost to protect the political and economic interests of America and its allies. For example, the United States 2013 country report on human rights regarding its United Kingdom ally noted, "Unsuccessful applicants for asylum and stateless persons are detained [in Britain] pending deportation," without highlighting the fact that those individuals are often held as well before they are given a hearing, suggesting a U.S. effort to avoid censuring its partner as well as an effort to avoid revealing its own practices, which are identical. ${ }^{22}$

Also, rape and domestic violence alone have not historically been grounds for asylum in the United States. They have been viewed instead as types of harm that could befall a group that could be categorized as sufficient for protection.
However, the identity of that group must be particular, immutable, and socially distinct. ${ }^{23}$ In consequence, "Persecution that more closely resembles western discrimination against women, such as rape or domestic violence, is less readily regarded as political." 24 As such, instead of considering acts of rape or wartime rape as political violence, asylum officers have often historically defined this scenario as not linked to a protected status outlined in legislation and international agreements. While this practice is changing with a recent landmark decision by the Board of Immigration Appeals finding that women who had been victims of domestic violence could be considered members of protected social groups, this fact highlights the centrality of state-centred criteria in officer discretionary decisionmaking. ${ }^{25}$ Moreover, in day-to-day adjudication of specific cases, there is no space or place for asylum officials to consider United States actions that could have contributed to the creation of refugees in the first place. Relevant law also does not ask whether the conditions confronting potential asylum-seekers constitute "an inevitable if unintended consequence of the international state system." 26

Asylum officers also simulate themselves as state arbiters and legitimize their roles by representing state logos concerning legal understandings of what qualifies an individual as an asylee. They are guided by requirements that "ensure that decisions are based on appropriate factors and correct application of the law." 27 USCIS officials translate refugee petition narratives into case facts and concentrate on determining whether an applicant's story fits protection definitions as outlined in the Immigration and Nationality Act, the Code of Federal Regulations, and relevant case law. These analyses employ country-of-origin information and "facts" to simplify complex narratives by sorting their elements into categories of supposed legal truths. In effect, asylum officers are "fix[ing] immigrant identities within networks of coded writing [to] perform instrumentalized readings of them. ${ }^{28}$ Ramji-Nogales, Schoenholtz, and Schrag have offered several hypotheses concerning why there are wide differences among judicial asylum decision-makers in their decisions and contend that the statutory definitions are actually difficult to implement. For this reason, in their view, immigration judges, like asylum officers, depend inescapably, and in considerable measure, on disposition and judgment. ${ }^{29}$ They have argued, therefore, that individual decision-makers can and do play distinctive, determinative roles in the asylum program's implementation and consequently its outcomes..$^{30}$

\section{Recognizing State Subjectivity and Breaking Down Binaries}

The United States employs asylum officers, and these individuals serve the sovereign's fraud-prevention and
(C) Author(s), 2015. This open-access work is licensed under a Creative Commons Attribution-NonCommercial 4.0 International license.
Cette oeuvre en libre accès fait l'object d'une licence Creative Commons Attribution-NonCommercial 4.0 International. 
security-assurance roles. Indeed, the regime delegates power to them to address those functions. However, a lack of awareness of the processes and implications of this manifestation of power through the officer's state simulation may lead to an over-emphasis or an overly broad approach to fraud prevention and security prevention. If officials are able to understand their representations of state logos, ethos, and pathos, then on an analytic level at least, they can identify the constructs and boundaries that are created by the government and simulated in their day-to-day work and adjust their frame of understanding accordingly. If officers become more aware of their state-centred subjectivity and how it influences their perceptions of threats to national security and to fraud, they can better ensure that they are not casting too wide a net, or unnecessarily inflating supposed risks. Instead, they can strive for a more nuanced understanding of what constitutes fraud and national security concerns and what are instead presuppositions created by the United States population protection agenda.

Dawson has observed that the refugee claims "process necessarily overlooks the fact that all stories-regardless of whether or not they were designed to tell the truth-are imaginative constructs shaped by the words that are available (or not) to the teller, and by the context in which they are told, heard, or read." 31

Similarly, Powell has suggested that as displaced applicants seeking asylum move across geographical space and time, the identities and realities of their narratives are rendered more complex..$^{22}$ As such, navigating the complicated reality of an applicant's story and claim for asylum within discourses of state power may prove difficult. As asylum officials exercise their authority through simulations of professionalization and state morality and legality, they routinely define refugee identity, perhaps unconsciously, as outside of the regime and a potential threat not only to national sovereignty, but also to the state-centred, state-protector identity that officers simulate.

In interpreting refugee applicant stories, "we [asylum officers] 'think like a state." 33 Perhaps such officials are "hungering for the 'coherent wholeness' that will allow us, in effect, to process his [the applicant's] claims, and to do so in a manner that demonstrates our altruism as the beneficent gatekeepers of a benign and manifestly multicultural nation." 34 Although asylum administrators may view themselves as part of a humanitarian regime, their construction of themselves as state through simulations of professionalization, governmental morality, and legality instead creates boundaries between them and their petitioners and makes it more difficult for them to perceive and address the tension implicit in their roles as protectors of human rights and of security and sovereignty.
As Powell has noted, "Naming individuals as [refugees] is a way to mark them as other, and discursively binds them with narrative expectations of displacement ... marking the displaced as other is a way of categorizing fears ... so that the other remains at a distance from ourselves."35

Indeed, the United States Asylum Division is charged with ensuring that there are no breaches to national security via fraud deterrence and detection. These aims are central to officers' roles as state agents. This point was well made in a 2013 report on assessing applicant credibility in European Union asylum systems: "Societal and political context is concerned with preventing irregular immigration and ensuring that the asylum system is not abused by persons fabricating evidence. Some determining authorities are located in government departments that have the objective to prevent irregular immigration. This may influence the mind-set of decision-makers and make it more challenging to implement an institutional culture in asylum procedures that is adequately human rights and protection-oriented." 36

Asylum officers' actions and decisions as adjudicators are tied to their state-centred subjectivity and they may therefore, presumably unconsciously, "other" applicants, perhaps even dehumanize them in their decision-making.

It seems reasonable to separate legitimate fraud concerns and the burnout among officers that may result from too often encountering individuals seeking to defraud the United States to gain entry, from our broader contention that asylum officials routinely enact state-centred criteria in their choices. While we recognize the problem of high levels of fraudulent claims, we want here to contend that that situation makes it all the more important that asylum officers be self-consciously aware of the in-principle claim for compassionate consideration of all petitioners notwithstanding. As the old saying goes, it is imperative not to throw the baby out with the bathwater if broader claims for due process and justice are to be served in the asylum adjudication process.

That is, responsible officials must be reflective and selfaware so as to avoid falling into "thinking like a state" in binaries that categorize themselves as gatekeeper (whether of the burned out or newly minted variety) and asylum applicants as simply national security threats. ${ }^{37}$ As Bhandar and Dawson have observed, "Because of the extent to which the new normal involves construing migrants as a security threat, any attempt to think critically about citizenship must begin 'by taking the position that citizenship should be viewed from the position of the immigrant, migrant, or refugee." 38

Taking this injunction seriously suggests a need for holistic adjudications that humanize the individuals seeking refuge and a new construction of the "normal" of asylum officer representations of state ethos, pathos, and logos.
(C) Author(s), 2015. This open-access work is licensed under a

Creative Commons Attribution-NonCommercial 4.0 International license.
Cette oeuvre en libre accès fait l'object d'une licence Creative Commons Attribution-NonCommercial 4.0 International. 
This involves breaking down nation-centred dichotomies and fixed categories of identity and truth grounded only in regime-grounded, structuralist understandings.

Moving from existing binaries requires that asylum officers employ creative conceptualizations. Many officers may do this subconsciously, but in order to draw conscious attention to state subjectivity, we can conceive creative conceptualizations in the form of what Stephenson and others have described as imaginaries. ${ }^{39}$ Stephenson has argued that leaders must "understand the imaginaries or ways in which others are viewing the world," and that they can do this by employing different "facets of imagination."40 Stephenson quoted Green, who has observed that practising imagination "is to become able to break with what is supposedly fixed and finished, objectively and independently real. It is to see beyond what the imaginer has called normal or 'common sensible' and to carve out new orders in experience."41 Although officers may already enact imaginaries without consciously calling their processes "imaginaries," Stephenson has identified four analytical facets of imagination-aesthetic, cognitive, affective, and moral - that can be employed to recognize, understand, rethink, and reframe asylum officer state-centred subjectivity.

\section{Challenging State Subjectivity: Aesthetic Imagination}

First, the form of imagination Stephenson dubbed "aesthetic" can be employed to "capture in a few words or a brief narrative or symbol a complex reality in order to obtain a connection and shared aspiration with those with whom they [leaders] are engaged." 42 This type of imagination can help officers avoid the trap of focusing foremost on fraud and national security concerns. Employing aesthetic practices offers an opportunity for decision-makers to recognize intricacies and complex symbols and metaphors present in petitioner stories and to use them to broaden narrow, engrained representational practices arising from the language of state security and protection. 43 This can help USCIS officials look beyond the state discourse to engage applicant narratives more fully instead of fitting them into predefined legal categories. In employing aesthetic imagination, officers can consciously recognize key points of meaning or components of the applicant's story and the complexities or different ways of knowing outside of official public discourse those narratives may convey.

For example, if an asylum officer is interviewing an applicant who claims to be a victim of domestic violence and rape, but who could not give an accurate account of the number of times she had been raped, or why she did not leave her spouse, or why she had returned to that partner previously reporting the situation, an officer may come to the conclusion that her narrative was not sufficiently detailed and/or contradictory, and might consequently perceive the story as fraudulent, as it did not fit easily within the confines of what is generally regarded as credible testimony.

However, if one uses the lens of aesthetic imagination, one can imagine the complex realities and meanings that underlie the concept of rape, instead of classifying it simply as a type of harm that can rise to the level of persecution in certain situations. Rape is not just one harmful act; it is a violation of external and internal freedoms, an imposition of power, an act of shaming, a loss of freedom, and a psychological penetration, among other complexities. When an applicant testifies about a rape, officers can conceptualize the harm that the individual has experienced as involving multifaceted realities of power and consider that their interplay may influence the manner in which an asylum-seeker testifies. In effect, aesthetic imagination can help uscis officials address complexities and intricate realities that do not otherwise accord neatly with established law and practice.

In addition to building more nuanced understandings of complex realities, aesthetic imagination can help officers identify symbols or metaphors in applicant narratives. Asylum officials can analyze artwork, photography, poetry, or literature regarding refugee flight in order to problematize and render visible symbols of state politics/power. This may allow decision-makers to identify instances where supposed scientific thinking could overshadow important symbols in asylum applicant realities. For example, if a Congolese woman testifies that men in uniforms came to her house and raped her, but she is not able to offer more information, an asylum officer might find identifying the particular motivations behind the harm she experienced challenging and may consider the applicant insufficiently credible and/or not able to access a protected legal justification for asylum. However, if this same official had previously analyzed symbolism in a creative work relating to an experience of a Tutsi Congolese woman who was raped by Mai Mai militiamen, for example, he or she might be able to consider that the individual applying for asylum could have been a representation of purity to those fighters, and that by raping her, they were making a political statement. This understanding of what befell the woman might offer the officer expanded opportunities for questioning that could generate testimony involving a protected ground for asylum. Analysts have developed an extensive literature concerning the implications of trauma for asylum-seekers and particularly how such events may shape their presentation of self and demeanour during the application process. For present purposes, the analytic question is one of seeking to ensure officer sensitivity to these complex realities during consideration of individual narratives and cases. 44
(C) Author(s), 2015. This open-access work is licensed under a Creative Commons Attribution-NonCommercial 4.0 International license.
Cette oeuvre en libre accès fait l'object d'une licence Creative Commons Attribution-NonCommercial 4.0 International. 


\section{Challenging State Subjectivity: Cognitive Imagination}

Officers can also employ cognitive imagination in their decision processes, which Stephenson has suggested involves "[sorting] through complex concerns, [understanding] them, and [suggesting] mechanisms by which they might reasonably be addressed" or "offering alternative conceptions of shared purpose and processes." 45 This form of thinking requires expanding one's frame to broaden collective "capacity to understand the basic assumptions and claims that underpin the arguments and worldview of others pressing alternate claims and a companion ability to develop new analytic frames that transcend those." 46

For example, "The REAL ID Act," which amended section 208 of the Immigration and Nationality Act, allowed officers to assess petitioners' demeanour, candour, and responsiveness when determining the credibility of their claims. ${ }^{47}$ This charge raised the importance to case outcomes of officials' perceptions of refugee physical and verbal cues. ${ }^{8}$ However, even though officers now have the legal right to deny a case on the basis of physical behaviour or verbal cues, they could nonetheless consider self-consciously their understanding of "expected" body language and human reactions and be sensitive to the fact that their perceptions do not necessarily translate to the "normal" understandings of those from different countries. ${ }^{49}$ In addition, individuals who have suffered trauma may be more likely to be nervous and act in "non-normal" ways during an asylum interview.

That is, uscis administrators could incorporate alternative possibilities so as to see applicant body language during interviews as states along a range of contextually appropriate behaviours, rather than dichotomized alternatives. Thereafter, instead of viewing a fidgeting applicant, or an individual who is not looking an interviewer in the eye, and concluding the person might be a threat to state sovereignty, officials can humanize the asylum-seeker's behaviours along a spectrum of normal. This opening up of conceptual space diminishes the psychological distance between the asylumseeker and the officer while granting a measure of deference to the petitioner. A similar example of this expansion of "normal" interpretations involves Western perspectives of gay identities. If asylum officials are able to conceive of sexual identity along a band of possibilities, then instead of pursuing lines of questioning common to Western notions, such as "coming out stories," that may not be applicable to individuals living in societies that are extremely oppressive to gay individuals, officials could pursue alternate areas of concern without assuming that the lack of a "coming out" story signals fraud..$^{\circ}$

\section{Challenging State Subjectivity: Affective Imagination}

The third facet of imagination that Stephenson has described, "affective imagination," involves a self-awareness that allows individuals to discipline themselves as they relate to other "different" individuals while practising empathy, or "[perceiving] the needs of those with whom they interact." officer with profound self-knowledge can confront how he or she constructs state subjectivities and can thereafter act on that knowledge and assist other decision-makers to develop such affective awareness and self-knowledge.

To exercise affective imagination, officers must recognize that the state and the refugee are discursively constructed and then acknowledge how uscis officials help to create and perpetuate that boundary by constituting themselves as state. Doty has recognized the silent presence of the self in research and practice and contended that there is "a power inherent in this absence, a power that enables [officers] to present their work as authoritative, objective and neutral." ${ }^{52}$ There is an unobtrusive state subjectivity in the adjudication decision, through the officer's re-authoring of the refugee story to accord with the state legal framework. While asylum decision-makers may pride themselves on their analytical reasoning abilities and their capacity to consider sociological, psychological, legal, and other perspectives in their analyses of cases, their role as protectors of state sovereignty suggests that they are neither objective nor neutral in their adjudications. As Hardy, Phillips, and Clegg have argued, one cannot just recognize "the situatedness of knowledge." Instead, "We need to develop new representational practices ... that reflect on the system."53 Ideally, this stance could lead to officers recognizing their state-oriented subjectivity, finding ways to mitigate it, and assisting asylum-seekers in understanding better how officers view them and why.

In short, using affective imagination could help asylum officials help themselves, but it could also assist other decision-makers to understand how their choices are shaped by state subjectivity. Officers can encourage each other to take advantage of opportunities for critical reflection and ask questions about the different influences, including the state's authority, that guide them as they make their decisions. As Stephenson has observed, "The significance of latent and rarely articulated ideas shape how engaged actors view their world or make sense of their environments. They do so, often unconsciously, on the basis of shared narratives, assumptions and claims. Likely, many would never express those unless brought to realize self-consciously their existence and contour." 54

Officers can and should undertake the effort to become conscious of their state-based dichotomizations and
(C) Author(s), 2015. This open-access work is licensed under a Creative Commons Attribution-NonCommercial 4.0 International license.
Cette oeuvre en libre accès fait l'object d'une licence Creative Commons Attribution-NonCommercial 4.0 International. 
assumptions. Gannon has suggested that taking time to ponder one's partiality through reflective writing, perhaps in the spirit of autoethnography, can be useful in revealing the power discourses that influence one's work: "Autoethnographic writing within a poststructuralist frame leans toward the ancient imperative to care for the self in a constant practice of reflective attention to the past, present, and future moments of subjectification within complex and contradictory discursive arenas." 55 uscis officers might well benefit from experimenting with just such practices.

In addition to educating themselves and other decisionmakers concerning broadening critical and reflective thinking in asylum adjudications, decision-makers can practise empathy in order to recognize applicants' perspectives and to acknowledge the fact that petitioners are unlikely to understand how officers create state subjectivity. This implies that asylum administrators must make an effort to educate applicants concerning the constructed character of the decision criteria they follow. This use of affective imagination demands empathy and it can start with assisting petitioners in understanding officers' logos, i.e., making a personal effort to ensure "plain language" explanations of different legal terms that guide decisions, but that refugees may not understand. For example, with certain types of asylum filings, uscis officers are required to provide a decision to applicants after their interview. If the official does not find the petitioner to have a credible fear of persecution or torture, she must inform the individual of her decision. This may result in applicants protesting that they do not understand why the administrator did not believe them. However, at the beginning of the interview, officers could instead help the refugee appreciate that they are truly listening to their stories and recognize that they may have suffered great trauma, but that what they are specifically adjudicating is whether their claim fits within state-specific definitions. If such were undertaken, petitioners could understand better that officers are not seeking to invalidate their stories as their primary aim. Instead, they are constrained by law concerning how to interpret the narrative they hear.

Practising empathy could also include making a personal effort to ensure the petitioner understands the ethos of asylum officers. In effect, uscis officials could help applicants grasp Western morality and how this shapes decisionmaking concerning their cases. For example, when officers ask petitioners many detailed questions about fraud and national security, they can inform petitioners that these are routine questions they ask all applicants, that they do consider fraud and national security issues, but that these concerns are just one part of the interview and that they are not singling them out. Additionally, administrators can explain that they recognize that structural violence or a complex array of interrelated factors, including economic concerns, could contribute to why the applicant experienced or might encounter harm in his country. Nonetheless, they are tasked with determining whether petitioner claims represent protected concerns as specified in United States law.

\section{Challenging State Subjectivity: Moral Imagination}

Finally, Stephenson has suggested that "moral imagination" is "inevitably linked to commons-related claims demanding that its practitioner act on behalf of a collectivity beyond self." ${ }^{6} 6$ usCis officers may enact moral imagination by making a conscious effort to practise cosmopolitan thinking in adjudications and employing techniques that do not "replace the nation state [ideology] but instead integrate it." 57 Instead of conceiving of themselves as simply U.S. Department of Homeland Security officials, officers could view themselves as wearers of multiple hats with responsibility for keeping the nation secure from external threats, but also as working in partnership with asylum decisionmakers around the world to ensure that eligible refugees are granted safe haven. That is, officials can avoid regarding petitioners solely within a United States-centred view and instead think of why/how refugees are created in the first place and why America subscribes to international law regarding this population. They could consider how their individual decisions affect an interconnected web of people and legitimize the refugee protection system as a whole. From this perspective, officials could consider applicants not just as individuals from another nation who represent a potential threat to the United States, but instead as people like themselves who have families, hopes, and dreams, who have allegedly undergone trauma, and who may in fact be a future neighbour or friend.

Multivocality may be used as a tool to realize this form of cosmopolitan thinking. Within the context of researcher (asylum officer, in this case) and research subject (refugee[s]) interaction, "multivocality can (a) highlight power differences in a research scenario between the researcher and participants, (b) encourage the researcher to consider how competing aspects of her or his identity shape relationships, and (c) expose underlying research vulnerabilities or tensions." 58 If officers employed multivocality during asylum adjudications, it could allow them to consider a case from multiple perspectives, including their personal identities as well as those of fellow neighbours or family members and so on, in addition to the state's stipulations. So, for example, in lieu of an administrator opening a file from a country known to have a high incidence of terrorist activity and automatically supposing that the person before them represents a potential threat to national security, or instead of picking up case documents from a nation belonging to a
(C) Author(s), 2015. This open-access work is licensed under a

Creative Commons Attribution-NonCommercial 4.0 International license.
Cette oeuvre en libre accès fait l'object d'une licence Creative Commons Attribution-NonCommercial 4.0 International. 
visa category that has a high incidence of fraud and assuming that this new application will also be fraudulent, the official can begin review of the file by asking, how can I best ensure protection of this applicant from individuals in his country who may be persecuting him, and how can I effectively ensure protection of this individual? This orientation integrates the nation-state system as a tool through which to dignify, humanize, and value individual applicants, while at the same time recognizing the officer's need to conduct thorough security checks.

Employing moral imagination through cosmopolitan thinking and multivocality can start with something as simple as sharing and drinking water with the applicant, or chatting before the interview about love for family, to create a human-level connection, instead of countenancing a formal and de facto adversarial relationship. As Doty has contended, asylum officials need to connect to the human beings and not just the objects of the state.59 This idea of connectedness "goes against the grain of traditional empiricism, which assumes that the knower and the known inhabit disconnected worlds."6o Instead, this notion of relatedness requires greater depth of understanding and feeling about those about whom decision-makers write. ${ }^{61}$ It involves recognizing one's own vulnerability, and feeling the horror and sadness in the applicant stories, and not viewing petitioners as just another case to process. This orientation also demands imagining claimants as a potential U.S. citizen. Similarly, it requires increased engagement with applicants and understanding of the asylum officer as an individual witness to refugee experiences. It requires official cognizance that all applicants deserve compassion. This stance involves not simply seeking to see the petitioner's story from the perspective of the asylum seeker, or trying as an officer to put herself in the applicant's shoes, but a willingness to be vulnerable to feelings during exchanges with petitioners.

\section{Conclusion}

Examining how asylum officials define refugee identities at the micro-level can supplement high-level policy analysis regarding the role and function of the state in humanitarian protection for refugees. U.S. asylum officers decide whether applicants should receive protection. The refugee officials' understanding of who qualifies as an asylee is enmeshed with their regime's power to determine who belongs within the sovereign realm and who does not. The Uscis officer simulates this state power through professionalization, or representing national ethos, through morality conditioning, or regime pathos, and also through formal legal interpretations, or exemplifying state logos.

Since protecting the sovereign realm is central to the duties of an asylum officer, fraud and national security concerns cannot and should not be ignored in status decisions. Nonetheless, state power creates "refugees." Asylum officers are often conditioned only to recognize their role as according legal recognition from the state in the form of asylum. As a result, de-centring to reflect critically on the role of the government in the categorization and subsequent adjudication of refugees is necessary. ${ }^{62}$ If officials do not consciously recognize, consider, and counter regime subjectivities, asylum applicants are likely to be seen as fact patterns and threats to state sovereignty. None of this is to suggest that other stakeholders in the process do not question regime criteria concerning asylum and otherwise work to ensure due process for claimants. Rather, it is to suggest only that asylum officers are positioned to accept and apply state law and assumptions rather than daily to inquire searchingly into them. What is at stake in this process for the state is the assurance of due process and a "fair hearing" for asylum seekers, even as against delimited criteria, and a clear role for the asylum officer that can at once help to secure that result and to allow these state actors space for considered understanding of their complex roles.

As officials listen to individual stories of displacement, they can protect national borders and simultaneously dignify refugees by employing forms of imagination to confront their own state-centred subjectivity and bias. Individual officers can and should be trained and encouraged to recognize their partiality through practices of aesthetic imagination, cognitive imagination, affective imagination, and moral imagination. They can extend their focus to envisioning complex realities and symbols in applicant narratives, broadening frames through reflective and critical thinking, practising empathy, and sensitizing other officers and applicants to their state-constructed subjectivity. These practices can help officers recognize and uncover their biases and help them identify fraud and national security threats while also upholding the United States government's ideals of human rights and freedom from oppression. Employing these forms of imagination can decrease the distance between asylum interviewers and applicants and allow refugees a genuine opportunity to receive a full hearing of their stories. ${ }^{63}$

Emily C. Barry-Murphy is an affiliate of the Virginia Tech Institute for Policy and Governance and she focuses her research on refugee regime democratization; she is interested in finding novel ways for refugees to have a greater voice in the structures that govern and define them. Although Dr. Barry-Murphy is program manager for one of the nine United States Asylum Offices and is a former Department of Homeland Security asylum officer, the views represented in
(C) Author(s), 2015. This open-access work is licensed under a Creative Commons Attribution-NonCommercial 4.0 International license.
Cette oeuvre en libre accès fait l'object d'une licence Creative Commons Attribution-NonCommercial 4.0 International. 
this article are her own and do not represent the views of the United States Government. The author may be contacted at emily.c.barry@gmail.com.

Max Stephenson Jr. serves as a professor of public and international affairs and the director of the Institute for Policy and Governance at Virginia Tech. His research and teaching interests include refugees and human rights, NGOs and international development, and peacebuilding and humanitarian relief. The author may be contacted at mstephen@vt.edu.

\section{Notes}

1 For more on the historical evolution of U.S. immigration and asylum law, see April Shemak, Asylum Speakers: Caribbean Refugees and Testimonial Discourse (New York: Fordham University Press, 2011): 5-8.

2 Cynthia Hardy, Nelson Phillips, and Stewart Clegg, "Reflexivity in Organization and Management Theory: A Study of the Production of the Research 'Subject," Human Relations 54 (2001): 541.

3 Ulrich Beck, Twenty Observations on a World in Turmoil (Cambridge, MA: Polity, 2012), 135.

4 Ibid., 137.

5 Cynthia Weber, Simulating Sovereignty: Intervention, the State and Symbolic Exchange (New York: Press Syndicate of the University of Cambridge, 2005).

6 Michel Foucault, Power/Knowledge: Selected Interviews and Other Writings, 1972-1977, ed. Colin Gordon, trans. Colin Gordon, Leo Marshal, John Mepham, and Kate Sober (New York: Pantheon, 1980). In Weber, Simulating Sovereignty, 33.

7 Weber, Simulating Sovereignty, 34.

8 Ibid.

9 Jean Baudrillard, Simulacra and Simulation, trans. Sheila Glaser (Ann Arbor: University of Michigan Press, 1995). In Cynthia Weber, Simulating Sovereignty.

10 Weber, Simulating Sovereignty, 6.

11 Ibid.

12 Ibid., 28.

13 Hardy, Phillips, and Clegg, "Reflexivity in Organization and Management Theory," 532.

14 Ibid.

15 Carol Bohmer and Amy Shuman, Rejecting Refugees: Political Asylum in the 21st Century (New York: Routledge, 2008), 1.

16 Philip Schrag, A Well-Founded Fear: The Congressional Battle to Save Political Asylum in America (New York: Routledge Publishers, 200o).

17 Hardy, Phillips and Clegg, "Reflexivity in Organization and Management Theory," 542.

18 Alexander Betts, Survival Migration: Failed Governance and the Crisis of Displacement (Ithaca, NY: Cornell University Press, 2013).

19 Juliet Stumpf, "Introduction," in Social Control and Justice Crimmigration in the Age of Fear, ed., Maartje van der Woude, and Joanne van der Leun, 7-16 (The Hague: Eleven International Publishing, 2013); César Cuauhtémoc Garcia Hernández, "Creating Crimmigration," Brigham University Law Review 6 (2013): 1457-1515.

20 April Shemak, Asylum Speakers: Caribbean Refugees and Testimonial Discourse (New York: Fordham University Press, 2011).

21 Bohmer and Shuman, Rejecting Refugees, 16.

22 United States Department of State, Country Reports on Human Rights Practices for 2013: United Kingdom 2013 Human Rights Report (Washington, DC: Bureau of Democracy, Human Rights and Labor, 2013), 6.

23 Matter of $M-E-V-G-, 26$ I\&N Dec. 227 (BIA 2014); Matter of $W-G-R-, 26$ I\&N Dec. 208 (BIA 2014).

24 Bohmer and Shuman, Rejecting Refugees, 6.

25 Amy Grenier, "Landmark Decision on Asylum Claims Recognizes Domestic Violence Victims," Immigration Impact, 2 September 2014, http://immigrationimpact. com/2014/o9/o2/landmark-decision-on-asylum-claimsrecognizes-domestic-violence-victims/.

26 Emma Haddad, The Refugee in International Society: Between Sovereigns (Cambridge, uk: Cambridge University Press, 2013), 2.

27 United States Citizenship and Immigration Services, Asylum Officer Basic Training-Decision Writing Part II: Legal Analysis (Washington, DC: Refugee, Asylum and International Operations Asylum Division, 2006), 4.

28 Carrie Dawson, "On Thinking Like a State and Reading (about) Refugees," Journal of Canadian Studies 45, no. 2 (2011): 61.

29 Andrew Schoenholtz, Philip Schrag, and Jaya RamjiNogales, Lives in the Balance: Asylum Adjudication by the Department of Homeland Security (New York: New York University Press, 2014), 208-11.

30 Jaya Ramji-Nogales, Andrew Schoenholtz, and Philip Scrag, Refugee Roulette: Disparities in Asylum Adjudication and Proposals for Reform (New York: New York University Press, 2011).

31 Dawson, "On Thinking Like a State and Reading (about) Refugees," 62.

32 Katrina Powell, "Rhetorics of Displacement: Constructing Identities in Forced Relocations," College English 74 (2012): 302.

33 Nandita Sharma, "Canadian Nationalism and the Making of a Global Apartheid," Women and Environment 68-9 (2005): 9. In Dawson, "On Thinking Like a State and Reading (about) Refugees," 69

34 Dawson, "On Thinking Like a State and Reading (about) Refugees," 69.

35 Powell, "Rhetorics of Displacement," 318.

36 The United Nations Refugee Agency and the European Refugee Fund of the European Commission, Beyond Proof: Credibility Assessment in EU Asylum Systems (Brussels: United Nations High Commissioner for Refugees, 2013), 39 .
(C) Author(s), 2015. This open-access work is licensed under a Creative Commons Attribution-NonCommercial 4.0 International license.
Cette oeuvre en libre accès fait l'object d'une licence Creative Commons Attribution-NonCommercial 4.0 International. 
37 Dawson, "On Thinking Like a State and Reading (about) Refugees," 64-70.

38 Davina Bhandar, "Renormalizing Citizenship and Life in Fortress North America," Citizenship Studies 8, no. 3 (2004): 275. In Dawson, "On Thinking Like a State and Reading (about) Refugees," 64.

39 Max Stephenson, Jr., "Exploring the Connections among Adaptive Leadership, Facets of Imagination and Social Imaginaries," Public Policy and Administration 24, no. 4 (2009): 417-35.

40 Ibid., 424.

41 Maxine Greene, Releasing the Imagination: Essays on Education, the Arts, and Social Change (San Francisco: JosseyBass Publishers, 1995), 19. In Stephenson, "Exploring the Connections among Adaptive Leadership," 424.

42 Stephenson, "Exploring the Connections among Adaptive Leadership," 426.

43 Roland Bleiker, Aesthetics and World Politics (Rethinking Peace and Conflict Studies) (New York: Palgrave Macmillan, 2009).

44 John Wilson and Boris Drozdek, eds., Broken Spirits: The Treatment of Traumatized Asylum Seekers, Refugees, War and Torture Victims (New York: Brunner-Routledge Publishers, 2004); Claudia Tazreiter, Asylum Seekers and the State: The Politics of Protection in a Security Conscious World (Aldershot, UK: Ashgate Publishing, 2004), especially 189-210.

45 Bleiker, Aesthetics and World Politics, 427.

46 Ibid.

47 REAL ID Act of 2005, Pub.L. No. 109-13, 119 Stat. $231 \$ 101(\mathrm{a})$ (3), amending new INA $\$ 208(\mathrm{~b})(1)(\mathrm{B})$ (iii), codified at 8 USC $\$ 1158(\mathrm{~b})(1)(\mathrm{B})(\mathrm{iii})$ (2012).

48 Audrey Macklin, "Truth and Consequences: Credibility Determination in the Refugee Context," in International Association of Refugee Law Judges Conference, 134-40 (Ottawa: International Association of Refugee Law Judges, 1998).

49 Cécile Rousseau, François Crépeau, Patricia Foxen, and France Houle, "The Complexity of Determining Refugeehood: A Multidisciplinary Analysis of the Decision-making Process of the Canadian Immigration and Refugee Board," Journal of Refugee Studies 15, no. 4 (2002): 43-70.
50 Rachel Lewis, "Lesbians under Surveillance: Same-Sex Immigration Reform, Gay Rights, and the Problem of Queer Liberalism," Social Justice: A Journal of Crime, Conflict, and World Order 37, no. 1 (2010): 90-106.

51 Stephenson, "Exploring the Connections among Adaptive Leadership," 428.

52 Roxanne Doty, "Autoethnography: Making Human Connections," Review of International Studies 36 (2010): 1048.

53 Hardy, Phillips, and Clegg, "Reflexivity in Organization and Management Theory," 555.

54 Stephenson, "Exploring the Connections among Adaptive Leadership," 423.

55 Susanne Gannon, "The (Im)Possibilities of Writing the Self-Writing: French Poststructural Theory and Autoethnography," Cultural Studies, Critical Methodologies 6 (2006): 480.

56 Stephenson, "Exploring the Connections among Adaptive Leadership," 429.

57 Beck, Twenty Observation on a World in Turmoil, 137.

58 Robert Mizzi, "Unraveling Researcher Subjectivity through Multivocality in Autoethnography," Journal of Research Practice 6 (2010): 7.

59 Doty, "Autoethnography," 1048.

6o Michael Jackson, Paths toward a Clearing: Radical Empiricism and Ethnographic Inquiry (Bloomington: Indiana University Press, 1989), cited in Caroline Ellis, "Emotional and Ethical Quagmires in Returning to the Field," Journal of Contemporary Ethnography 24 (1995): 94.

61 Ruth Behar, The Vulnerable Observer: Anthropology That Breaks your Heart (Boston: Beacon, 1997), 165.

62 Michel Agier, Managing the Undesirables: Refugee Camps and Humanitarian Government, trans. David Fernbach (Malden, MA: Polity, 2011).

63 The lead author of this article has designed and successfully offered a training program for fifty asylum officers at a DHS-USCIS regional office based on the argument offered here. Division leaders have expressed interest in providing the workshop to additional asylum decision-makers at other offices.
(C) Author(s), 2015. This open-access work is licensed under a Creative Commons Attribution-NonCommercial 4.0 International license.
Cette oeuvre en libre accès fait l'object d'une licence Creative Commons Attribution-NonCommercial 4.0 International. 
(C) Author(s), 2015. This open-access work is licensed under a Creative Commons Attribution-NonCommercial 4.0 International license.
Cette oeuvre en libre accès fait l'object d'une licence Creative Commons Attribution-NonCommercial 4.0 International. 


\title{
"We Are in the Middle of Two Great Powers": Refugees, Activists, and Government during the Plattsburgh Border Crisis of 1987
}

\author{
JOHN ROSINBUM
}

\begin{abstract}
In early 1987 the Canadian government closed its border to hundreds of would-be refugees streaming north from the United States. Forced to flee the newly passed Immigration Reform and Control Act, refugees from Central America, Southeast Asia, and eastern Africa found themselves trapped between the two countries. This article examines the reasons for the Canadian government's policy shift, the temporary refugee camp it created in upstate New York, and the camp's effect on the border town of Plattsburgh, NY.
\end{abstract}

\section{Résumé}

En début 1987, le gouvernement canadien décida de fermer sa frontière, précédemment ouverte, à des centaines de réfugiés potentiels en provenance des États-Unis, obligés de fuir vers le nord en raison de l'adoption récente d'une loi sur la réforme et le contrôle de l'immigration (Immigration Reform and Control Act). Des réfugiés de l'Amérique centrale, de l'Asie du Sud-Est, et de l'Afrique orientale se sont ainsi trouvés pris dans une position incertaine entre ces deux pays. Cet article étudie les raisons pour ce changement de politique de la part du gouvernement canadien, le camp de réfugiés temporaire qui en résulta dans le nord de l'État de New York et l'impact du camp sur la ville frontalière de Plattsburgh, NY.

\begin{abstract}
We are in the middle of two great powers, the U.S. and Canada. The U.S. doesn't want us here. Canada doesn't want us - now anyway. I can't go back to Salvador. So we wait here.
\end{abstract}

—“Carlos,” March 1, $1987^{1}$

I truly believe that was Plattsburgh's finest hour.

-Rose M. Pandozy,

Clinton County Social Services Commissioner,

August 3, 2012 ${ }^{2}$

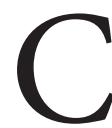
onfused and often penniless, hundreds of would-be refugees like Carlos found themselves unexpectedly trapped between Canada and the United States. On February 20, 1987, Canadian immigration officials barred hundreds of prospective refugees from entering Canada until after their asylum applications had been processed, effectively stranding them in small communities just south of the U.S.-Canada border. This refusal took most refugee claimants from the sixteen war-torn countries on Canada's B-1 list by surprise. Prior to February 20, nationals from countries on the B-1 list who applied for asylum at a Canadian port of entry were automatically accepted into Canada while immigration reviewed their asylum applications. The list reflected the Canadian government's belief that most of those nationals had deserving claims for asylum.

Canada's suddenly closed gates shocked refugees and activists who knew of Canada's previous reputation as a welcoming country for refugees. Just a few months prior to Canada's revocation of the B-1 list, the United Nations High Commissioner for Refugees awarded the Canadian people the Fridjof Nansen Medal for outstanding service
(C) Author(s), 2015. This open-access work is licensed under a Creative Commons Attribution-NonCommercial 4.0 International license.
Cette oeuvre en libre accès fait l'object d'une licence Creative Commons Attribution-NonCommercial 4.0 International. 
to refugees, marking the first time the award was given to a people or government. 3 This article examines why, with such a sterling record in refugee rights, the Canadian government reversed course, what happened to the refugees it rejected, and how the arrival of hundreds of refugees transformed the communities they were stranded in.

Canada's change in policy stemmed from a shifting refugee and immigration climate in Canada brought on by shifts in global refugee flows, administrative inefficiencies in Canada's immigration office, and a public fearful of an "overwhelming" tide of refugees. One of the most notable consequences of this policy was the creation of refugee shelters along the U.S.-Canada border. Particularly interesting is what I call the "Plattsburgh Border Crisis" in Plattsburgh, NY. This small town of fewer than 30,000 people suddenly found itself, in the spring of 1987, hosting hundreds of refugees trapped between a border newly sealed by the Canadian government, and a U.S. Immigration and Naturalization Service (INs) threatening to deport them. During the course of four months, refugees, activists, and local government officials built and maintained a temporary refugee camp, caring for up to 200 refugees while also providing legal and educational services. I argue that though the Plattsburgh Border Crisis grew out of transnational changes in immigration and refugee policy, the local response demonstrates the ways that refugees, public services, private charities, and citizens can cooperate to provide temporary refuge in spite of state disregard and active national hostility. In Plattsburgh, this experience transformed both the participants and the region.

A few scholars have examined the ways that U.S. and Canadian refugee policy shaped each other during the 1980 . Most notable among them is María Cristina García’s Seeking Refuge: Central American Migration to Mexico, the United States, and Canada. Some studies of U.S. and Canadian asylum policy briefly mention Canada's closing of the border in February 1987. In Transnational Ruptures, Catherine Nolin discusses how changes in U.S. immigration legislation in 1986 created "asylum demand" across the U.S.-Canada border. Julie Young's "Seeking Sanctuary in a Border City: Sanctuary Movement(s) across the Canada-us Border" pays particular attention to the collaboration between Sanctuary Movement groups in Detroit and Windsor during the 1980 s and early 1990s, briefly discussing the Canadian government's decision to close the border to asylum-seekers in 1987. None of these examinations detail the effects of that decision on border communities, like Plattsburgh. The only book written specifically on Plattsburgh's experience is a self-published memoir by Fran Ford, a local activist highly involved in refugee care. 4
This article draws on newspaper reports, oral histories taken during two trips to the region, government archives, and secondary literature. The interviews cited here, as well as off-the-record conversations with activists and government officials, added extra context to my research. Collectively, they demonstrate how a series of legislative and policy decisions in Canada and the United States created the crisis, how a small community banded together with its resident refugees to meet a rapidly developing humanitarian crisis, and how the experience had lasting effects on its participants and the community.

The Canadian government's decision to close its border in February 1987 emanated from changes in the ways that the country and its citizens perceived and interacted with refugees from around the world. During the 1970 s and 1980 o Canada resettled a significant number of refugees from countries like Chile and Uganda, most of whom were screened and selected by Canadian officials at their respective embassies. Seemingly geographically isolated from refugee-generating countries, policy-makers did not expect significant numbers of refugees to arrive on Canada's shores or ports of entry. The few refugees who entered Canada unbidden were mostly welcomed, and deportation was relatively scarce. Throughout most of the 1980s, Canada deserved its reputation as a refugee-welcoming country, making its 1987 change in policy so surprising to many refugees. ${ }^{5}$

In reality, the Canadian government's decision had been building throughout the decade. In their sweeping history of Canadian immigration policy, Ninette Kelley and Michael Trebilcock argue, “The Immigration Department's inability to handle the inland-refugee claim backlog is the dominant theme in Canada's immigration history in the 1980s." 6 The backlog they refer to came from pending asylum applications by prospective refugees in Canada. Many applications remained in limbo for months, if not years, waiting for the claim to be adjudicated. This led, in large part, to the closing of the border in 1987. Three factors exacerbated the backlog in late 1986 and made it into a domestic crisis that required action: an ineffective and time-consuming adjudication system, well-publicized perceived "abuses" of the system, and the passage of the Immigration Reform and Control Act (IRCA) by the United States.

The first factor, administrative inefficiencies, came from an overwhelmed refugee determination system that was never prepared for the high volume of claimants who arrived during the 1980 os. In 1976 the Canadian government modernized its immigration system in an attempt to meet its changing workforce needs and humanitarian obligations. The government included a refugee measure that created a highly detailed and arduous two-step adjudication. A 1985
(C) Author(s), 2015. This open-access work is licensed under a Creative Commons Attribution-NonCommercial 4.0 International license.
Cette oeuvre en libre accès fait l'object d'une licence Creative Commons Attribution-NonCommercial 4.0 International. 
Canadian Supreme Court ruling, Singh v Canada, added another step by granting each prospective refugee the right to oral hearings. This quickly overwhelmed the system, creating an extensive backlog that granted any immigrant who claimed refugee status de facto landed status for the months, if not years, it took to adjudicate the claim.

In 1985 the backlog was at 3,710 applications. ${ }^{7}$ In spite of a partial amnesty granted to over 20,000 applicants in May 1986, the backlog remained at over 3,500 applications at the end of 1986. Canadian government officials and the media worried about the development and persistence of the backlog, as it reinforced the image of an overwhelmed and incompetent immigration system. Most importantly, in the minds of many policy-makers, the backlog prompted what many in the Canadian press and government called an abuse of the system. ${ }^{8}$

This concern was the second factor in the closing of the border. In 1986, nearly 2,000 Turkish immigrants arrived in Canada, claiming refugee status due to economic persecution. Over the period of six months, 1,00o Portuguese Jehovah's Witnesses asked for protection in Canada from religious persecution. ${ }^{9}$ The press, in conjunction with the Canadian government, labelled these refugees as "abusers" of the system, contrasting claimants fleeing peaceful but "under-developed" European countries with refugees from war-torn nations in Central America and Africa. ${ }^{10}$ The majority of these immigrants arrived in Canada by air. In response, the Canadian government started warning airline carriers that they bore the burden of carrying unaccepted asylum applicants back to their countries of birth. The arrival of 155 Tamils from war-torn Sri Lanka on August 11, 1986, proved to be the most publicized "abuse" of the system. A number of fishermen found the Tamils off the coast of Newfoundland in the lifeboats that they had been forced into by freighter captain Wolfgang Blindel.

The government gave "minister permits" to the Sri Lankans to stay in the country for one year to wait for the violence to settle in Sri Lanka. ${ }^{11}$ This ignited a media firestorm with charges of "queue jumping" over other immigrants and worries that others would imitate the Tamil refugees. This intensified after the papers learned that the Sri Lankans had unsuccessfully claimed refugee status in West Germany before proceeding to Canada. For the rest of the year the press obsessed over the story, first focusing on the dramatic rescue of 155 people huddled in lifeboats by picturesque fishermen and then whether the Tamils should be allowed to stay in the country or not. Finally, the media closely followed the government's attempt to prosecute Blindel. ${ }^{12}$ The arrival of refugees continued to loom large in the public eye for most of 1986 and into 1987. While many Canadians remained concerned about refugees slowly arriving by sea and by air, these could be construed as isolated events that improved airline policies and the Canadian Coast Guard could control. It took one final event to prompt the Canadian government to close its land border with the United States to incoming refugees.

The third factor in the Canadian government's closure of its border came from U.S. legislation. The Immigration Reform and Control Act of 1986 was the first major overhaul to the U.S. immigration system since the 1965 Immigration and Nationality Act. The product of a growing anti-immigrant groundswell within the country, the IRCA outlined strict penalties to those who employed undocumented immigrants and a road to amnesty to those who entered the country illegally but could prove to the government that they had maintained a continuous residence in the United States since 1982. ${ }^{13}$ In 1986 most undocumented immigrants did not believe that they met the criteria for amnesty, particularly those who had fled from the horrific civil wars in Guatemala and El Salvador but were unable to obtain refugee status from the United States. Their employers, fearing the new employment penalties, fired many of the potential refugees. As a result, undocumented refugees in the United States faced a vexing issue. Unwilling and unable to return to their countries of birth, they still needed to support themselves and their families. Thousands turned to Canada as a potential safe haven after hearing of Canada's more liberal asylum policies. Between December 1986, one month after the passage of the IRCA, and February 1987, when Canada closed its borders, over 10,000 would-be refugees crossed the border into Canada. ${ }^{14}$

For refugees the three main routes from the United States to Canada were Seattle to Vancouver, Detroit or Buffalo to Toronto, and New York, via Plattsburgh, to Montreal. Montreal acutely felt the influx of refugees. Its airport was already a primary destination for Turkish and Portuguese refugee applicants. Local and national newspapers ran headlines such as "Central Americans Pour into Canada Seeking New Homes," and "Quebec Feels Budget Pinch as Refugees Keep Arriving." 15 The Globe and Mail cited a government estimate that over 1,100 new refugees had arrived during a ten-day span in late December and early January. ${ }^{16}$ The Toronto Star added another government estimate: over 600 of the year's recent arrivals were Central Americans who had crossed the border by bus from the United States to Quebec. ${ }^{17}$ This only added to the widespread fears of an overwhelmed refugee-determination system already established by the Tamil, Turkish, and Portuguese controversies.

The government listened. On January 15, Benoit Bouchard, the minister for employment and immigration, told reporters, "The law allows the minister, while waiting to find the personnel necessary to deal with these cases quickly, to
(C) Author(s), 2015. This open-access work is licensed under a Creative Commons Attribution-NonCommercial 4.0 International license.
Cette oeuvre en libre accès fait l'object d'une licence Creative Commons Attribution-NonCommercial 4.0 International. 
leave those people on the other side of the border. Are we going to use this method? It is too soon to say." 18 A month later Gerry Weiner, the minister of state for immigration, promised changes to immigration policy that would guarantee "the orderly control of refugee claimants through the country." 19 On February 20 the government released its changes in refugee policy. The government established new visa transit requirements, ended the "minister's permits" system and abolished the B-1 list. ${ }^{20}$

A combination of an overwhelmed refugee-determination system, media coverage of "foreign refugees" arriving on Canadian shores, and a sudden influx of refugees brought on by U.S. immigration policy ended Canada's B-1 policy of allowing Guatemalans, Salvadorans, Sri Lankans, and nationals from thirteen other countries immediate entrance into Canada. Instead, the hundreds of refugees streaming weekly from the United States to Canada found themselves halted at the line between the two countries. At crossing stations along the border, Canadian officials interviewed, processed, and then sent prospective refugees back to the United States to wait for a hearing date four to six weeks in the future. For those living in the United States without legal permission, this meant being sent back into the arms of the U.S. Border Patrol that was legally bound to deport them. Plattsburgh, twenty miles south of the main border crossing to Montreal, was on the verge of transforming from a sleepy community near the border to a makeshift refugee camp.

In late February 1987, at the Champlain border crossing, just twenty miles north of Plattsburgh and thirty-eight miles south of Montreal, Greg Ledges, supervisor and immigration inspector for the United States Immigration and Naturalization Service, heard Canada was about to close the border. He was unsure of the consequences. Multiple Greyhound buses that passed through the border checkpoint every day on their way to Montreal were carrying prospective refugees to apply for asylum in Canada. Going north, the buses never concerned him or his colleagues, who monitored those who entered the United States, not those leaving. Most people crossing the Champlain border passed through quickly, as they were either Canadian or U.S. citizens. ${ }^{21}$

Following Minister Bouchard's announcement on Friday, February 20, Canadian immigration officials began to process and send potential refugees back across the border. Though the exact number of refugees turned away by Canadian officials at the Champlain border crossing over the weekend is unknown, one refugee relief activist in Plattsburgh (where most of those turned away at the Champlain border crossing went) estimated it at over 200.22 At the border, refugees met with U.S. immigration officers. If refugees still had documents such as a visa or temporary permit authorizing them to remain in the United States, INS officers immediately released them. Those without legal status were processed for deportation and were assigned either voluntary or involuntary departure. Migrants usually received involuntary departure if they had a criminal record or an outstanding deportation order.

Canadian activists charged that refugees forced to wait in the United States by Canada's policy change were in danger of deportation back to their home country. When first announcing the change in policy, Bouchard told the press and members of the opposition party that migrants were safe from deportation, but a few days later, after newspapers published a letter from the head of the INs contradicting Bouchard's claim, he retracted his comments. ${ }^{23}$

The U.S. Border Patrol sent involuntary deportees to prison to await transit back to their home countries, while those eligible for voluntary deportation received papers and were told to leave the United States by a certain date. As Mr. Ledges remembered it, the entire process from crossing the border into Canada through Canadian processing and U.S. processing, to either release or imprisonment, could take longer than ten hours. ${ }^{24}$ Following processing, churches, non-profits, and government agencies could legally assist migrants. For a variety of organizations in Plattsburgh who offered prospective refugees protection, this was an important distinction. IRCA, which most of the refugees were fleeing, made it a penalty to "conceal, harbor, or shield from protection" undocumented and unprocessed immigrants. ${ }^{25}$ Processing by the Border Patrol legally shielded Plattsburgh organizations.

The village of Champlain, a small cluster of houses and businesses just south of the Canadian/U.S. border, had no place for rejected refugees to stay, so those who did not go to jail received a bus ride back to Plattsburgh, the nearest U.S. town. ${ }^{26}$ Though larger than Champlain, Plattsburgh claimed fewer than 30,000 residents. Its economic mainstays came from a U.S. Air Force base and a branch of the State University of New York (suny Plattsburgh). In addition, it remains the closest U.S. city of any size to Montreal. Canadians in search of U.S. goods or services often shopped in Plattsburgh. In turn, Plattsburgh residents often took trips north to Montreal to watch Major League Baseball's Montreal Expos. Plattsburgh was, in many ways, a quintessential border town. Yet, because traffic across the border was relatively unrestricted, the border did not loom large in the city's imagination. The residents prided themselves in their community's hospitality, a virtue that the border crisis tested tremendously in early 1987.

For the first few months following IRCA's passage, a growing stream of immigrants and refugees passed through Plattsburgh, but the numbers remained small and their stay
(C) Author(s), 2015. This open-access work is licensed under a Creative Commons Attribution-NonCommercial 4.0 International license.
Cette oeuvre en libre accès fait l'object d'une licence Creative Commons Attribution-NonCommercial 4.0 International. 
short. On February 21, refugees turned back at the U.S. Canada border began to arrive in Plattsburgh in numbers the town had never seen before. The Plattsburgh Border Crisis had begun.

The Plattsburgh Community Crisis Center (PCCC) responded first. Founded in 1970, the PCCC, headed by Brian Smith, offered assistance to homeless, impoverished, and mentally ill Plattsburgh residents. It proved to be a crucial part of Plattsburgh's refugee relief effort. During first few days of the crisis, the PCCC took the lead. After learning that refugees were stranded at the local bus station, Brian Smith and the centre swung into action, housing refugees at local motel rooms and providing them with food. On Monday, February 23, the local Plattsburgh Press-Republican printed a front-page story about the refugees' arrival, announcing the onset of the crisis and the actions taken up to that point. It was quickly becoming clear that the centre did not have the resources for the emerging crisis. Most importantly, it did not have the space to house, nor the money to support, incoming refugees. As the border crisis evolved, other involved organizations included the Salvation Army, the Red Cross, Clinton County Social Services, Catholic Charities, and the Ecumenical Food Shelf. Within the first week Rose Pandozy, the Clinton County social services commis sioner, formed a committee with the department heads of the various services. As Pandozy remembers it, the cooperation between local service organizations was seamless. Throughout the refugee relief effort, "If we knew we needed another agency, we just called them up and they came."27 Plattsburgh community leaders decided to set up an emergency shelter at the Salvation Army to provide more space for refugees and to conserve fast-dwindling resources. ${ }^{28}$

The new shelter at the Salvation Army had the capacity to house approximately 100 refugees. While enough for the first few days of the crisis, it soon reached capacity. Brian Smith, Rose Pandozy, and other leaders of the refugee relief effort began looking for other options. On February 27 they found a temporary solution at a local building called "The Office" that housed 90 more. While the building provided a place for people to sleep, it lacked beds, showers, and a kitchen. Thus, volunteers had to transport sheltered refugees back and forth for showers and bring food. Clearly, this was not a permanent solution. Smith and Pandozy kept looking. ${ }^{29}$

Volunteers and local government officials began to publicly express anger over the lack of state and federal support. One unnamed charity head complained in the local newspaper, "It's a sad thing. The government created this problem, but they're dumping all the responsibility on the poor people of a small community."3o That very day a local National Guard unit offered to temporarily house refugees in its armoury. Refugees could stay in the armoury only while the unit could guarantee the site's security. Therefore, when the unit left for military manoeuvres in two weeks, the community had to find alternative housing. Though grateful for help from the state, the refugee relief leaders were desperate to secure permanent assistance. To make matters worse, the leaders had no way of ascertaining the scope of the crisis. As William Donnell, the coordinator of Plattsburgh's Office of Emergency Preparedness, explained, "Weeks from now we could have 200 or even 300 [refugees]. We have to stay prepared." 31

Three days later the National Guard at Saranac Lake, a village over fifty miles away in Franklin County, extended an invitation for refugees to stay at its armoury. After long deliberation, the relief leaders rejected its offer. Upon investigating the location, they found its facilities and location unsuitable. Too far away from social services and without sufficient facilities to safely house refugees, the armoury would be a logistical nightmare. ${ }^{32}$

On March 4 leaders finally secured a solution that lasted through May. The Association for Retarded Children (ARC) offered its new building just west of the city. The 30,000-square-foot building could house over 150 refugees and had facilities for showers and cooking. Yet it was little more than an empty shell. The cavernous main room offered little privacy for families. Activists set up "privacy cubicles" throughout the main room. Three walls with a sheet in the front, they offered a measure of seclusion. In addition, the refugee relief effort needed to build showers and provide additional toilets, washers, and dryers. While imperfect, the ARC meant an end to the shuttling of refugees back and forth. The improvements came to approximately $\$ 60,000$. Rose Pandozy, who by this time had taken the lead in the refugee relief effort, believed that she could secure assistance from the state. 33

Pandozy travelled to Albany on March 5 to meet with New York's Department of Social Services and ask for help. The commissioner told her there was no assistance available. Pandozy asked for the decision in writing so she could share it with the local, state, and international reporters who were already starting to come to Plattsburgh. Though Pandozy never released a statement to the media, this threat had the desired effect. On March 6 New York Governor Mario Cuomo released $\$ 177,000$ in emergency funds to Clinton County to help provide for the refugees. 34

Two days later the refugees moved into the ARC shelter. For the next three months the ARC building served as the sole shelter for refugees in Plattsburgh awaiting their hearing. On June 10 the housing situation for the refugee relief effort went full circle. The ARC moved into its new building, and most refugees returned to local motels. A few
(C) Author(s), 2015. This open-access work is licensed under a Creative Commons Attribution-NonCommercial 4.0 International license.
Cette oeuvre en libre accès fait l'object d'une licence Creative Commons Attribution-NonCommercial 4.0 International. 
temporarily moved in with host families who housed the refugees while awaiting their hearing.

During the three months in the ARC, local government officials, refugees, and volunteers interacted in fascinating ways. Each of the three groups had varying, though overlapping, views of how the community should respond to the Plattsburgh Border Crisis. The three leading government/ semi-government officials, Pandozy, Brian Smith, and Captain Jack Holcomb of the Salvation Army, saw the shelter as the answer to a humanitarian crisis that needed support. Largely bereft of assistance from state or federal authorities, Pandozy and Smith took the lead in determining how to pay for shelter, food, and medical assistance for an unknown number of refugees. It was not an easy task, as the number of refugees fluctuated wildly over the first few months, as did their medical needs. At one point Holcomb predicted over 500 refugees. ${ }^{35}$ Nonetheless, Smith and Pandozy found the funds through a skilful use of political persuasion (see Pandozy's trip to Albany) and cooperation with local charities and fundraising.

As the leader of the local Salvation Army chapter, Holcomb took charge of the day-to-day operations of the shelter. One of the most quoted figures in the media reports on the relief effort, some volunteers expressed unhappiness with Holcomb's brusque demeanour and perceived tendency to spend more time with reporters than at the shelter. ${ }^{36}$ Holcomb was, without a doubt, a formidable presence. A number of interviewees recalled an incident at the shelter in late May when Holcomb called the entire building for a meeting. He sternly excoriated unnamed individuals for keeping alcohol in the shelter, general rowdiness, and invasions of privacy. The most memorable part came when he halted his address to search a young man's cubicle. Holcomb found a quart of liquor. In stony silence he marched across the main room into the men's bathroom and poured the alcohol down the drain, then re-emerged to hurl the empty bottle into the trash. ${ }^{37}$ Following the closure of the shelter in June 1987, Holcomb's role in the refugee relief effort shrank, as he was no longer responsible for the day-to-day care of the refugees.

While government and closely allied officials oversaw the setup and overall operation of the shelter, its residents made it work. ${ }^{38}$ During the shelter's three months, the plurality of refugees came from Central America. Individuals from around the globe joined them. Refugees arrived in varying socio-economic circumstances, some able to provide for themselves, while others came with little more than the clothes on their backs. ${ }^{39}$ Language skills varied widely. While many of the refugees were fluent in English, others only spoke Spanish, French, Arabic, Tamil, Amharic, or other languages. Similarly, many refugees entered the shelter in desperate need of medical attention. ${ }^{40}$
The one thing in common for refugees arriving in the first few weeks was that they did not expect to be in Plattsburgh. An invisible line, manned by Canadian immigration officials, kept them in the United States. Waiting at the shelter for their applications to be adjudicated, they negotiated and created a safe space on a shoestring budget. Frustrated, confused, and desperate, refugees worked with volunteers and government officials at the shelter to create a space that provided temporary routines in their new lives.

These new routines included volunteering around the shelter. Some refugees offered to cook. Though it presented a unique challenge due to varying dietary restrictions and preferences, cooking provided a diversion from the monotony of waiting for adjudication. Others cleaned, babysat, helped with paperwork, and volunteered to conduct security patrols. As the shelter population grew to over 150, security became a concern. Initially, volunteers from the Salvation Army and local community conducted patrols through the shelter, but the refugees quickly took control themselves. ${ }^{41}$ One Salvadoran, "Oscar," led in the organization of security patrols. Well respected by the other refugees, Oscar came from a middle-class background and had extensive business experience, as well as a master's from Michigan State. For the month that he lived in the shelter Oscar drafted the lists for the work crews and helped set up security patrols. ${ }^{42}$

Refugees also organized special events and classes, which included talent shows, picnics, and a Mother's Day celebration. At the conclusion of a talent show on March 19 the refugees sang "God Bless America," an interesting choice, given that most were fleeing U.S. immigration laws. ${ }^{43}$ Though most of the refugees in Plattsburgh wanted to settle in francophone Quebec, few knew how to speak French. Walid Houri, a Lebanese refugee, conducted free introductory French classes to all who needed them. ${ }^{4}$

In addition to doing volunteer work, many refugees gave individual and group interviews to the press. Newspaper reporters and television crews from across the United States, Canada, and the rest of the world discovered Plattsburgh's charm and found themselves fascinated by its residents and the refugees who were forced to temporarily call it home. Immediately after the crisis began, the Montreal Gazette published a front-page story called "Dreams of New Life Shattered at Border," with a picture of two young Salvadorans and the caption "My life is in danger and I can't go back." 45 The Gazette continued its coverage and was joined by other national and international outlets including the Globe and Mail, Toronto Star, New York Times, and Philadelphia Inquirer, as well as distributors like the Associated Press and United Press International. Refugees used these interviews as opportunities to make a political statement, highlighting the reasons for their flight and the injustices
(C) Author(s), 2015. This open-access work is licensed under a Creative Commons Attribution-NonCommercial 4.0 International license.
Cette oeuvre en libre accès fait l'object d'une licence Creative Commons Attribution-NonCommercial 4.0 International. 
of the U.S. and Canadian refugee systems. Through chores, talent shows, and interviews, refugees transformed the shelter from a space born out of necessity into a sanctuary and site of political action.

While refugees provided stirring images and heartbreaking quotes, reporters also took interest in the plainspeaking volunteers who staffed the refugee relief effort. They had good reason to. One of the most fascinating parts of the Plattsburgh Border Crisis was the way that members of a relatively conservative rural community responded to an unforeseen, and, for many, unwelcome, emergency. At first, the unknown aspects of the crisis intimidated many Plattsburgh and Clinton County residents, even those who agreed to volunteer. Fran Ford, who went on to become one of the shelter's most prolific volunteers, remembers taking two refugees to the doctor's office on her first day: "I took a seat across the room, the farthest chair I could find. Why? Was I embarrassed to be seen with these women that were different in language and appearance? Yes I was!"46 Within a few weeks Mrs. Ford went from answering phones to serving as a jack of all trades, running errands with refugees, counselling deeply scarred women, inviting refugees over for dinner, and serving as a go-between for volunteers and government officials. 47

Margot Zeglis, who went on to become the relief effort's volunteer coordinator, moved to Plattsburgh into the midst of the crisis. She recalls that she and her husband "drove into town in a big snowstorm, stayed in a hotel and I heard about the need for volunteers and that's how I got involved." A veteran of a variety of non-profits, Zeglis used her experience to organize the effort's volunteers. She describes recruiting, training and placing volunteers as a series of questions: "Well, start with their names: what do you like to do? And then ... putting out a range of what are the immediate needs, and trying to fit people who want to do those. A volunteer is a pretty valuable asset, and you only asked of them what they want to do." The range of volunteers surprised her: "All ages, financial backgrounds. Religions. I was amazed by how many men there were. Usually you don't get a lot of men but we had a lot of men as volunteers. And husbands and wives." ${ }^{38}$ Local Plattsburgh businesses answered the call as well. The owner of a muffler shop donated his time and money, while other local businesses donated food and clothing. 49

The academic community got involved as well. Professors from SUNY Plattsburgh offered translation and paralegal services. A variety of Plattsburgh undergraduates, members of the Alpha Phi Omega fraternity, as well as high school Model un students raised money for the refugees. For some Plattsburgh undergraduates this represented a unique opportunity, as they were participating in a Model
Organization of the American States (OAS) and had just been chosen to represent El Salvador. The faculty leader of the Model OAs, Stuart Voss, worked as a paralegal for many refugees. At the shelter, students met and interacted with refugees to supplement their learning..$^{\circ}$

In addition, volunteers from outside the immediate community responded. During the first weekend of the crisis, residents of Hemmingford, a village less than five miles north of the border, drove a Volkswagen bus stuffed with food and clothing down to the Crisis Center. Disagreeing with their government's policy, they returned the following weekend, providing entertainment and religious services. ${ }^{51}$ The interviews and media coverage of the refugees and volunteers and Plattsburgh touched concerned citizens across the United States, who took to the media, writing letters to the editor and publishing articles in an attempt to raise money and awareness for the Plattsburgh volunteer groups. Nancy Murray, president of the Syracuse Interreligious Council, issued an explicitly religious appeal for financial support, asserting that, like the Israelites wandering in the desert after fleeing Egypt, "today's strangers in a foreign land need our manna to survive." 52 Donations began streaming in, first from around the region and then the country.

Of course not everyone in the community responded positively to the crisis. There were concerns similar to those in Canada that had led to the closing of the border. Some Plattsburgh residents questioned the wisdom of expending so many resources on refugees while Plattsburgh residents went hungry and homeless. One letter to the editor claimed, "The refugee problem could easily be solved by taking the money for one day's maintenance and buying each refugee who can't afford one a one-way ticket to Albany along with a map [to the] State Campus and the South Mall."'53 Other letters echoed the sentiment. Nonetheless, future events proved that. though the refugee relief effort came with some initial costs, it generated several unexpected benefits.

The most tangible benefit came a little more than seven months after the letter to the editor quoted above. Tiny Clinton County secured a \$1 million grant from New York State's Homeless and Housing Assistance Program. It was the third-largest grant for the program, only behind the much more populated regions of New York City and Westchester County. Brian Smith and Rose Pandozy, the authors of the grant proposal, credited Plattsburgh's response to the refugee crisis to their luck with the proposal.54 Three years later Smith, Pandozy and other community leaders dedicated the Evergreen Townhouse Community, an innovative grant-funded low-income housing complex. The grant increased by $\$ 700,000$ to $\$ 1.7$ million to make, in the words of State Social Services Commissioner Cesar A. Perales, "a little community of its own." 55 The Evergreen Townhouse
(C) Author(s), 2015. This open-access work is licensed under a Creative Commons Attribution-NonCommercial 4.0 International license.
Cette oeuvre en libre accès fait l'object d'une licence Creative Commons Attribution-NonCommercial 4.0 International. 
Community remains a crucial part of Clinton County's and Plattsburgh's social services.

Other, less tangible effects on the community included a broadening of horizons by area churches and residents who had raised funds, clothing, and food during the relief effort. Prior to the border crisis, people of the community thought of themselves as friendly and neighbourly, but the refugee relief effort was demonstrable proof of those virtues to themselves and the world. Today the First Presbyterian Church in Plattsburgh has extensive outreach programs at home and abroad. Mission of Hope, a charity centred in Plattsburgh, makes yearly visits to Nicaragua for humanitarian and missionary work..$^{56}$

In this article's second opening quotation, Rose Pandozy calls the response to the Plattsburgh Border Crisis the community's "finest hour." Various members of the community, when interviewed, echoed her sentiment. They believed that the willingness of the town's and county's social service organizations to band together to meet a crisis proved the area's hospitality. Volunteer coordinator Margot Zeglis lauded Plattsburgh's response, "Plattsburgh has a lot to be very proud of. They really, really rose above it all."57

The crisis also formed lasting friendships among Plattsburgh residents while spending long hours at the shelter, grieving the fate of family members, laughing over the inanities of everyday life, and inviting refugees over for dinner. While conducting interviews in Plattsburgh, many of the activists referred me to their fellow volunteers, indicating that nearly thirty years after the crisis, they remained in touch. They mentioned recent dinners or coffee meetings between fellow activists who are now old friends. ${ }^{58}$

A little over a year after the shelter's closing, many of the refugees, volunteers, and local government officials reunited in Montreal for a picnic. Organized by Fran Ford, Margot Zeglis, and the Kiwanis Clubs of Plattsburgh and Montreal, the August 21, 1988, picnic was, for many refugees and volunteers, the first they had seen of each other after refugees left the shelter. Refugees, activists, and government officials filled the day with song, laughter, good food, and a special visit from Santa Claus. Even though it was in the middle of the summer, Ron Wood, a Plattsburgh volunteer, reprised his role as St. Nicholas, which he had played at a party for the refugees last Christmas. ${ }^{59}$

That picnic in August of 1988 did not end Plattsburgh's interactions with refugees. To this day, Plattsburgh remains a way station for prospective refugees intent on applying for asylum in Canada. Yet the picnic is a powerful reminder that the crisis was, in many ways, overcome by the generosity of and cooperation between refugees, volunteers, and local government officials. While they did not end the refugee flow or change Canadian policy, these three groups found a way to transform a desperate situation into a negotiable one. None of the refugees who came knocking at Plattsburgh's door starved or went homeless. The "tide of refugees" never overwhelmed Plattsburgh's social services. Rather, it led to the construction of top-of-the-line low-income housing. And while some citizens expressed discomfort over the aid given to refugees, in the end the experience became one of civic pride that the community still remembers fondly.

The Plattsburgh Border Crisis also temporarily transformed Plattsburgh, as a space, into a hub of global networks. Civil wars in Central America, Southeast Asia, Afghanistan, and Africa pushed refugees out of local camps and into Western countries. Policy and legislation in Canada and the United States forced refugees from their homes across the United States and into a collection of border zones in Seattle, Detroit, Buffalo, and Plattsburgh, where they waited for the Canadian government to decide their fate. As these border zones struggled to deal with the ramifications of these changes brought on by an ineffective refugee adjudication system, a panicked Canadian media, and the IRCA, the Canadian government tabled its new proposal for refugee adjudication, C-55, supplemented by an anti-smuggling bill (C-84) in early summer of 1987.

Noteworthy among Bill C-55's statutes was the "safe third country" provision, which denied asylum applicants if they had already passed through what was deemed a safe third country. Refugee advocates feared that for foreign policy reasons the government would deem the United States a "safe country," thereby making the vast majority of Central American applicants ineligible. Though Bills C-55 and C-84 passed in July 1988, the Canadian government never compiled the safe third country list, sparing Canadian officials the embarrassment of excluding the United States. ${ }^{60}$ This further proved that Canada's government needed to take a global, rather than domestic approach to its immigration, refugee, and asylum policy. The local and international forces that caused the Plattsburgh Border Crisis continued, just like the friendships and goodwill that it created.

John Rosinbum teaches North American and world history at Arizona State University and BASIS Tucson North. His research into immigration examines the interactions among refugees, activists, and government officials during the Central American refugee crisis. As an educator, he is engaged in research on the ways that history education has changed in response to shifts in the education marketplace and how digital tools can advance teaching and learning. The author may be contacted at john.rosinbum@gmail.com.
(C) Author(s), 2015. This open-access work is licensed under a Creative Commons Attribution-NonCommercial 4.0 International license.
Cette oeuvre en libre accès fait l'object d'une licence Creative Commons Attribution-NonCommercial 4.0 International. 


\section{NOTES}

1 "Carlos," quoted in Howard Witt, "Canada Shutting Door to Waves of Aliens," Chicago Tribune, March 1, 1987.

2 Rose Pandozy, interview with author, Plattsburgh, NY, August 3, 2012.

3 Maria Christina Garcia, Seeking Refuge: Central American Migration to Mexico, the United States and Canada (Berkeley: University of California Press, 2006), 122.

4 Ibid.; Catherine Nolin, Transnational Ruptures: Gender and Forced Migration (New York: Ashgate Publishing, 2006), 100-7; Julie Young, "Seeking Sanctuary in a Border City: Sanctuary Movement(s) across the Canada-us Border," in Sanctuary Practices in International Perspectives: Migration, Citizenship and Social Movements, ed. Randy Lippert and Sean Rehaag (New York: Routledge, 2012), 236-9; and Fran Ford, I Will Remember You: A Testament to Both Tenderness of the Human Heart and the Strength of the Human Soul (Interlaken, NY: Windswept, 1994).

5 For a more complete overview of the Canadian government's approach to refugees during the 1980s, see Gerald E. Dirks, Controversy and Complexity: Canadian Immigration Policy during the 1980 s (Montreal: McGill University Press, 1995), 77-97.

6 Ninette Kelley and Michael Trebilcock, Making of the Mosaic: A History of Canadian Immigration Policy (Toronto: University of Toronto Press, 1998), 412.

7 Employment and Immigration Canada, Annual Report (Ottawa, 1984-5), 69.

8 Dirks, Controversy and Complexity, 85 .

9 Kelley and Trebilcock, Making of the Mosaic, 414-15.

10 Alfred Holden, "Canada Will Keep Doors Open to Refugees, Minister Declares," Toronto Star (hereafter TS), December 31, 1986; Francois Shalom, "Canadians Fear Asian Influx, Minister Says," Globe and Mail (hereafter GM), December 31, 1986.

11 Alexandra Mann, "Refugees Who Arrive by Boat and Canada's Commitment to the Refugee Convention: A Discursive Analysis," Refuge 26, no. 2 (2009): 195-6.

12 Patricia Orwen, Ts, October 8, December 30, 1986.

13 Daniel J. Tichenor, Dividing Lines: The Politics of Immigration Control in America (Princeton, NJ: Princeton University Press, 2002), 262-4.

14 Garcia, Seeking Refuge, 131.

15 "Central Americans Pour into Canada Seeking New Homes," TS, January 14, 1987; Canadian Press, "Quebec Feels Budget Pinch as Refugees Keep Arriving," GM, December 22, 1986.

16 Victor Malarek, "Flood of Arrivals Strains Province's Programs," GM, January 6, 1987.

17 Arch MacKenzie, "U.S. Refugee Crackdown Boosts Exodus to Canada," TS, January 15, 1987.

18 Quoted in "Bouchard Considering Change to Make Refgees Wait in U.S.," GM January 16, 1987.
19 Quoted in Alexandra Radkewycz, "Weiner Decries Attitude of Many toward Refugee Status," GM, February 16, 1987; "Claimants," GM, February 16, 1987.

20 Victor Malarek, "Ottawa Acts to Stop Torrent of Refugees," GM, February 20, 1987.

21 Greg Ledges, telephone interview with author, September 5, 2012.

22 Jack Downs, "Refused by Canada, Aliens Seek Shelter," Plattsburgh Press Republican (hereafter PPR), February 23, 1987.

23 Victor Malarek, "Refugee Claimants May Face Deportation," GM, February 24, 1987.

24 Greg Ledges, telephone interview with author, September 5, 2012.

25 See Immigration Reform and Control Act, section 112 (c).

26 For the purposes of this article, I treat the town of Plattsburgh and the city of Plattsburgh as one entity. While separate governing bodies, they collaborated together and with Clinton County to provide the services discussed here.

27 Pandozy, August 3, 2012.

28 Jack Downs, "Refused by Canada," PPR, February 23, 1987.

29 Mitch Rosenquist, "Second Refugee Shelter Opens," $P P R$, February 27, 1987.

30 Tom Bergin, “Anger Reigns over Fugitive Aid," PPR, February $27,1987$.

31 Jack Downs, "National Guard Armory to House More Refugees," PPR, March 2, 1987.

32 Tom Bergis, "Saranac Lake Eyed for Refugees," $P P R$, March 3, 1987 .

33 Bruce Rowland, "Aliens to Go to ARC Building," $P P R$, March 5, 1987.

34 Tom Bergin, "\$177,00o in State Aid for Refugee Effort," $P P R$, March 5, 1987; Rose Pandozy, interview with author, August 3, 2012.

35 Tom Bergin, "Flow of Refugees Eases; Shelter at Capacity," PPR, February 26, 1987.

36 Ford, I Will Remember, 64.

37 Ibid., 70-1.

38 Joe LoTempio, "Refugees Find Comfort in Shared Situations," PPR, February 23, 1987.

39 Ford, I Will Remember, 12. Darlene Pavone, the relief effort's lead nurse for much of the spring of 1987, recalls that one woman arrived with intense internal bleeding due to a botched medical operation that prevented her from menstruating. Darlene Pavone, telephone interview with author, August, 8, 2012.

40 Mitch Rosenquist, "Refugees Fear Persecution," $P P R$, March 3, 1987.

41 Ford, I Will Remember, 34.

42 Ibid., 52. "Oscar" made a strong impression on most of the Plattsburgh volunteers I interviewed.

43 Tom Foster, "Waiting Refugees Kept Busy with Activities, Learning," Syracuse Post-Standard, March 26, 1987.
(C) Author(s), 2015. This open-access work is licensed under a Creative Commons Attribution-NonCommercial 4.0 International license.
Cette oeuvre en libre accès fait l'object d'une licence Creative Commons Attribution-NonCommercial 4.0 International. 
44 James Goodman, "In an Emergency Refugee shelter," USA Today, April 20, 1987.

45 Karen Seidman, "Dreams of New Life Shattered at Border," Montreal Gazette, February 23, 1987.

46 Ford, I Will Remember, 15.

47 Helen G. McLeod, “'I Will Remember You:' Refugee Book Now in Print," PPR, August 21, 1994. Every Plattsburgh volunteer and government official I interviewed spoke highly of Mrs. Ford and her contributions to the refugee relief effort.

48 Margo Zeglis, interview with author, tape recording, Plattsburgh, NY, August 3, 2012.

49 Rick Lyman, "Stranded, Fearful of U.S. Law, Refugees Pin Hopes on Entering Canada," Philadelphia Inquirer, March 7, 1987; Fran Ford, interview with author, Plattsburgh, NY, August 2, 2012.

50 Stuart Voss, telephone interview with author, August 24, 2012; Steve Manor, "Model U.N. Students Collect for Refugees," $P P R$, March 6, 1987.

51 Joe LoTemplio, "State to Pay for Refugee Care," PPR, February $25,1987$.
52 Nancy S. Murray, "Strangers in a Strange Land," Syracuse Post-Standard, March 17, 1987.

53 "Speak Out: Aliens," PPR, March 6, 1987.

54 Tom Bergin, "\$1 Million Grant to Build Welfare Housing," $P P R$, October 23, 1987; Rose Pandozy, author interview, Plattsburgh, NY, August 2, 2012.

55 Quoted in Joe LoTemplio, "Evergreen Townhouse Community Dedicated," PPR, June 5, 1990.

56 Stuart Voss, telephone interview with author, August 24, 2012.

57 Zeglis, interview with author, August 3, 2012.

58 Pandozy, interview with author, August 2, 2012; Fran Ford, interview with author, August 2, 2012; Stuart Voss, telephone interview with author, August 24, 2012; Zeglis, interview with author, August 3, 2012.

59 Ford, I Will Remember, 139-40; Cathy Supple, "Reunion Held for Former Refugees and Volunteers," North Country Catholic, September 7, 1988.

60 Dirks, Controversy and Complexity, 89-94.
(C) Author(s), 2015. This open-access work is licensed under a

Creative Commons Attribution-NonCommercial 4.0 International license.
Cette oeuvre en libre accès fait l'object d'une licence Creative Commons Attribution-NonCommercial 4.0 International. 


\title{
The Psycho-Social Conditions of Asylum-Seekers from Darfur in Israel
}

\author{
VERED SLONIM-NEVO, SHIRLEY REGEV, AND YIFTACH MILLO
}

\begin{abstract}
OBJECTIVE

The study appraises the prevalence of pre-migration trauma exposure, the ability to secure basic living needs, and psychological functioning among Darfuri asylumseekers and refugees living in Israel.
\end{abstract}

\section{METHOD}

The sample included 340 adults from Darfur. Standardized measures assessing socio-psychological functioning were utilized.

\section{RESULTS}

The participants demonstrated high rates of pre-migration exposure to traumatic experiences. Thirty per cent of the participants met DSM-IV criteria PTSD, with a higher proportion for women than for men. Post-migration stressors were mentioned by the majority of the participants.

\section{CONCLUSIONS}

The State of Israel should recognize past atrocities and traumas of Darfuris who arrived in Israel. Such recognition should be offered as acceptance of their rightful access to refugee status determination. Moreover, the State of Israel needs to modify government policies and legalization facilities so that Darfuri refugees and asylum-seekers will have access to basic human needs and support services.

\section{Résumé}

\section{OBJECTIF}

Cette étude évalue la prépondérance de traumatisme prémigratoire auquel sont exposés les demandeurs d'asile et réfugiés du Darfour vivant en Israël, ainsi que leur fonctionnement psychologique, et leur capacité de se procurer les besoins vitaux de base.

MÉTHODE

L'échantillon pour l'étude était constitué de 340 adultes du Darfour. Divers aspects de leur fonctionnement sociopsychologique étaient évalués à l'aide de mesures normalisées. RÉSULTATS

Les participants ont fait preuve de niveaux élevés d'exposition prémigratoire aux expériences traumatiques: $30 \%$ des participants ont satisfait aux critères du DSM-IV pour l'ESPT, avec une proportion plus élevée chez les femmes que chez les hommes. Des facteurs de stress postmigratoire ont été évoqués par la majorité des participants.

CONCLUSIONS

L'État d'Israël devrait reconnaître les atrocités et les traumatismes antérieurs subis par les Darfouriens arrivant en Israël. Cette reconnaissance devrait se manifester par une acceptation de leur droit d'accès légitime à la Détermination du statut de réfugié. Par ailleurs, il incombe à l'État d'Israël de modifier les politiques gouvernementales ainsi que les dispositifs de légalisation afin que les réfugiés et les demandeurs d'asile du Darfour puissent accéder aux services humanitaires de base et de soutien.

S ince 2003, the war in Darfur has led to more than 300,000 Darfuris' deaths, internal displacement of two million citizens, and led 350,000 refugees to cross borders seeking protection against genocide committed by the Sudanese government and paramilitary groups, including killings, rape, and burning of villages. ${ }^{1}$ Many have fled to Egypt. However, violent acts by Egyptian police led many
(C) Author(s), 2015. This open-access work is licensed under a Creative Commons Attribution-NonCommercial 4.0 International license.
Cette oeuvre en libre accès fait l'object d'une licence Creative Commons Attribution-NonCommercial 4.0 International. 
to cross the border to Israel, hoping that Israel would provide them with protection. ${ }^{2}$

The initial few hundreds of Sudanese who crossed the Egyptian border were placed under administrative detention in line with the "Entry into Israel Law."3 In 2006, their custody was prolonged under the Anti-Infiltration Lawlegislation allowing the indefinite detention of those crossing the Israeli border illegally. After a petition to Israel's Supreme Court, asylum-seekers were released. They were provided with a temporary group protection, defending them from deportation, but denying them access to refugee status determination (RSD) and the rights associated with legal residency. In 2008, the government of Israel granted 490 temporary residence visas ( $\left.A_{5}\right)$ to Darfuri asylum-seekers. This group is identified in this study as "refugees" (or as "with visa") and is entitled to public services. The other group is identified here as "asylum-seekers" (or as "without visa") and is holding a temporary protection visa (A2-5 A), which grants them only protection from deportation.

The Darfuri community in Israel consists mostly of men. They encompass the majority of the 12,825 Sudanese asylumseekers registered by the Israeli Population, Immigration and Borders Authority. ${ }^{4}$ Many initially settled in the southern city of Eilat, where employment in the hotel industry was accessible. With the saturation of available work in Eilat, many moved to Tel Aviv, establishing their lives in the southern neighbourhoods around the central bus station, where accommodation was cheaper and humanitarian assistance was available by Israeli NGOs. Regrettably, the Israeli government refuses to develop an asylum policy, while it continues to impose punitive measures intended to deter further asylum-seekers from arriving in Israel. 5 These measures included geographical restrictions, blocked access for asylum-seekers to RSD; prohibited employment; forced return of asylum-seekers from the border into Egypt; and adoption of the anti-infiltration law in 2013. The law allows the Israeli authorities to hold individuals whom they regard as "infiltrators" in detention centres without charge or trial. ${ }^{6}$ Many Darfuris were transferred to the new centre of Hollot in the Negev Desert, built for this purpose. This act was followed by an opposition of the detainees and by a protest of human-rights NGos.7 The consistent pressures, insecurity, and increasing xenophobia led many to return to Sudan. Some have since disappeared or have been imprisoned. ${ }^{8}$ In September 2014, the Israeli High Court of Justice invalidated the anti-infiltration legislation and ordered the state to shut down Hollot and re-examine the cases of all those detained within ninety days. ${ }^{9}$ This decision was ignored by the Knesset, which in turn approved an amended law, reducing detention at Hollot to twenty months. ${ }^{10}$ Apparently, new attempts by the Israeli government to keep asylum-seekers in detention centres are expected, as well as struggle to release these persons and provide them with basic human rights. In addition, Israel's Immigration Authority has been promoting a policy of "voluntary" return/deportation, which provides an alternative to detention, offering $\$ 3,500$ and a one-way ticket to Sudan, Eritrea, Uganda, or Rwanda.

In this article, we describe the refugees' experiences in Israel, their psychosocial functioning, and their quality of life in order to shed light on their plight. The study was conducted prior to the decision to detain asylum seekers in Hollot. Thus, our findings do not reflect the current experience of the Darfuris who are afraid of incarceration or have already been transferred to Hollot.

\section{Four Stages in the Refugee Experience}

Four stages in the lives of refugees are often described in the literature. Our study relates to them.

First stage, the pre-migration period: an extended period characterized by economic difficulties, social problems, political oppression, extreme physical and emotional suffering, and long periods of hiding and escaping from armed forces. The main motivation to escape is the fear of being attacked, rape, torture, and ethnic cleansing. ${ }^{11}$

Second stage, the escape: the experience of leaving home, family, and friends; refugees experience dangers on their escape route, including torture; women report sexual attacks. ${ }^{12}$

Third stage, temporary settlement or request for asylum: extended stay in refugee camps, detention centres, or urban centres in host countries. Although the refugees feel physically protected, the processes of obtaining legal recognition and of securing reunification with their families often lead to extreme anxiety; fears of deportation lead to even greater anxiety and social marginalization. ${ }^{13}$

Fourth stage, resettlement, local integration, or return to country of origin. Refugees often struggle with uncertainty and find it difficult to reorganize themselves at all levels. Some manage to become official refugees in their new countries with a right to permanent settlement. Settlement, however, often creates a need to struggle with xenophobia, racialism, unemployment, and cultural conflicts. The challenges of securing basic needs spill over to a struggle for self-identity. ${ }^{14}$

\section{Theoretical Perspective}

Forced migrants go through a process of adapting to the new environment. In Bronfenbrenner's ecological systems theory, ${ }^{15}$ the outcomes of this developmental process depend on the interaction between the individual and his or her environment. Thus, in order to understand how asylum seekers adjust, we ought to examine both individual
(C) Author(s), 2015. This open-access work is licensed under a Creative Commons Attribution-NonCommercial 4.0 International license.
Cette oeuvre en libre accès fait l'object d'une licence Creative Commons Attribution-NonCommercial 4.0 International. 
and environmental characteristics. The theory presents 4 systems that affect individuals' development: (1) the microsystem-immediate contexts in which the individual participates directly (e.g., interactions among asylum-seekers' family members); (2) the meso-system-interconnections among the micro-systems (e.g., interactions between asylum-seekers and local institutions such as hospitals, and immigration authorities); (3) the exo-system-contexts that are not experienced directly by an individual but may influence his or her development (e.g., problems in the workplace); and (4) the macro-system-contexts that reflect the broad social, political, and ideological norms of the culture in which the individual lives (e.g., the political situation in the host country).

The variables in this study cover all 4 systems that affect participants' psychosocial well-being. For example, language proficiency, family relations, and psychological well-being are all part of the micro-system; perceived discrimination and interaction with health services may be considered part of the meso-system; employment and living difficulties may be part of the exo-system; and legal status and past traumatic events are part of the macro-system, both in the home country and in the host country.

\section{Methods}

Design

The study used a cross-sectional survey design. The data were collected during January-December 2012.

\section{Sample}

The sample consists of 340 participants, 64 females and 276 males, aged 18 or older, who were born in Darfur. At the time of recruiting, they lived either in the centre of the country or in the south of Israel. Participants were recruited through a contact list of Darfuri refugees who are members in an organization called "The Sons of Darfur." The list served as an initial sampling frame from which names were drawn randomly. However, much of the contact information was out of date, as many of the Darfuris had changed their addresses without notification. Therefore, we recruited the participants by using snowball sampling methods, and by approaching potential participants in social gathering places. Thus, response rates cannot be established.

The majority of the respondents were males $(81 \%)$, Muslims (99\%), about 30 years of age, had not yet gained legal status (83\%), came from rural areas (59\%), had completed about 10 years of education, left Sudan about 4 years earlier, were about 2.5 years in Israel, and had spent time in an Israeli detention centre ( $85 \%$ ) (see table 1$)$.
Table 1. The socio-demographic characteristics of the sample

\begin{tabular}{|c|c|c|c|c|c|}
\hline & $\begin{array}{l}\text { Male } \\
(N= \\
276)\end{array}$ & $\begin{array}{l}\text { Female } \\
(N=64)\end{array}$ & $\begin{array}{l}\text { Has a visa } \\
(N=58)\end{array}$ & $\begin{array}{l}\text { No visa } \\
(N= \\
282)\end{array}$ & $\begin{array}{l}\text { Total } \\
(N= \\
340)\end{array}$ \\
\hline Age $(M, S D)$ & $\begin{array}{l}31.2 \\
(6.2)^{* *}\end{array}$ & $\begin{array}{l}27.2 \\
(5.8)^{* *}\end{array}$ & $32.1(5.6)$ & $30.2(6.5)$ & $\begin{array}{l}30.6 \\
(6.4)\end{array}$ \\
\hline \multicolumn{6}{|l|}{ Residency in } \\
\hline \multicolumn{6}{|l|}{ Sudan } \\
\hline Urban & $43 \%$ & $34 \%$ & $46 \%$ & $40 \%$ & $41 \%$ \\
\hline Rural & $57 \%$ & $66 \%$ & $54 \%$ & $60 \%$ & $59 \%$ \\
\hline \multicolumn{6}{|l|}{ Marital status } \\
\hline Married & $30 \% * *$ & $92 \% * *$ & $43 \%$ & $42 \%$ & $42 \%$ \\
\hline Unmarried & $70 \% * *$ & $8 \% * *$ & $57 \%$ & $58 \%$ & $58 \%$ \\
\hline \multicolumn{6}{|l|}{ Has off- } \\
\hline $\begin{array}{l}\text { spring } \\
\text { No off- }\end{array}$ & \multicolumn{5}{|c|}{ No off- } \\
\hline spring & $74 \% * *$ & $31 \% * *$ & $64 \%$ & $66 \%$ & $66 \%$ \\
\hline $\begin{array}{l}\text { Level of } \\
\text { religiosity }\end{array}$ & & & & & 3.3 \\
\hline$(M, S D)^{\mathrm{a}}$ & $3.3(1.2)$ & $3.6(1.4)$ & $3.0(1.3)^{*}$ & $3.4(1.2)^{*}$ & $(1.2)$ \\
\hline $\begin{array}{l}\text { Years of } \\
\text { education }\end{array}$ & \multicolumn{4}{|c|}{ Years of } & 9.8 \\
\hline$(M, S D)$ & $(3.9)^{*}$ & $8.5(5.6)^{*}$ & $9.4(4.5)$ & $9.9(4.2)$ & (4.3) \\
\hline \multicolumn{6}{|l|}{ Time since } \\
\hline from Sudan & & & & 3.6 & 4.2 \\
\hline (in years, $M, S D$ ) & $4.4(3.5)$ & $3.7(2.8)$ & $7.4(2.8)^{* *}$ & $(3.2)^{* *}$ & $(3.4)$ \\
\hline \multicolumn{6}{|l|}{ Length of stay } \\
\hline $\begin{array}{l}\text { in Israel (in } \\
\text { years, } M, S D \text { ) }\end{array}$ & $2.8(1.7)$ & $2.6(1.6)$ & $4.4(1.3)^{* *}$ & $\begin{array}{l}2.4 \\
(1.5)^{* *}\end{array}$ & $\begin{array}{l}2.8 \\
(1.7)\end{array}$ \\
\hline $\begin{array}{l}\text { Locations } \\
\text { before arriv- } \\
\text { ing in Israel }\end{array}$ & & & & & \\
\hline Egypt & $74 \%$ & $72 \%$ & $85 \% *$ & $71 \% *$ & $73 \%$ \\
\hline Libya & NA & NA & $7 \%$ & $6 \%$ & $6 \%$ \\
\hline \multicolumn{6}{|l|}{$\begin{array}{l}\text { Stayed in } \\
\text { detention } \\
\text { centre in } \\
\text { Israel }\end{array}$} \\
\hline Yes & $88 \% * *$ & $72 \%{ }^{* *}$ & $62 \% * *$ & $90 \% * *$ & $85 \%$ \\
\hline No & $12 \%^{* *}$ & $28 \% * *$ & $38 \% * *$ & $10 \% * *$ & $15 \%$ \\
\hline $\begin{array}{l}\text { Stayed in } \\
\text { detention or } \\
\text { refugee } \\
\text { centre in }\end{array}$ & & & & & \\
\hline \multicolumn{6}{|l|}{ Egypt } \\
\hline Yes & $18 \% *$ & $6 \% *$ & $45 \% * *$ & $10 \% * *$ & $16 \%$ \\
\hline No & $82 \% *$ & $94 \% *$ & $55 \% * *$ & $90 \% * *$ & $84 \%$ \\
\hline
\end{tabular}

$\mathrm{a}_{1}$ to 5 higher scores indicating higher levels of religiosity

${ }^{*} p<.05 ;{ }^{* *} p<.01$
(C) Author(s), 2015. This open-access work is licensed under a Creative Commons Attribution-NonCommercial 4.0 International license.
Cette oeuvre en libre accès fait l'object d'une licence Creative Commons Attribution-NonCommercial 4.0 International. 


\section{Data Collection}

Nine interviewers, who were themselves from Darfur, collected the data. They conducted face-to-face interviews, usually at participants' residences.

\section{Ethical Considerations}

Ethical approval for the project was provided by the research ethics committee in Ben-Gurion University and a consent form was obtained. All data collected were confidential and anonymous. The participants received a gift card worth 100 Israeli shekels as compensation for their time.

\section{Measures}

\section{Stages 1 and 2}

\section{Pre-Immigration Traumatic Events}

A modified version of the Harvard Trauma Questionnaire (HTQ) was used. ${ }^{16}$ It includes 21 traumatic events and it ranges from 1-21, with higher scores indicating more events. The internal consistency and stability correlations in this study were good (Cronbach's $\alpha=.84 ; r=.94, p<.001$ ).

\section{Stage 3}

\section{Daily Lives in Israel}

Language proficiency in Hebrew. We used a self-report 4-item questionnaire regarding the level of understanding, speaking, reading, and writing in Hebrew. The scale ranges from 1 to 4 , with higher scores indicating greater proficiency. The internal consistency and stability correlations in this study were good (Cronbach's $\alpha=.88 ; r=.69, p<.001$ ).

Living conditions. Difficulties in living conditions were measured via a 24 -item scale adapted from the Post-Migration Living Difficulty Questionnaire (PMLD). ${ }^{17}$ PMLD ranges from 1 to 24 , with higher scores indicating more problems. The internal consistency of this scale in this study was high $(\alpha=.91)$ but it was not stable across time $(r=.35, n s)$.

Perceived discrimination. The scale consists of 5 items asking whether the respondent had experienced being disadvantaged, compared to native Israelis, at work, in the neighbourhood, when shopping, in government offices, and in bars or restaurants. The scale ranges from 1 to 4 , with higher scores reflecting a higher level of discrimination. The internal reliability of the scale in this study was high $(\alpha=.91)$ and the consistency across time was acceptable $(r=.58, p<.01)$.

\section{Psychological Functioning}

Quality of Life The World Health Organization Quality of Life: Brief Version (WHOQOL-BREF) ${ }^{18}$ is a 26 -item self-report scale that measures 4 domains of quality of life in the last 2 weeks:
(1) physical health (e.g., energy and fatigue), (2) psychological health (e.g., self-esteem), (3) social relationships (e.g., social support), and (4) environment (e.g., transportation). Participants answered on a 5 -point scale, ranging from 1 to 5 . The score for each domain is calculated as the mean score of items within each domain multiplied by 4 , to make domain scores comparable with the full version of the questionnaire (i.e., WHOQOL-10o). Hence, domain scores range from 4 to 20. In this study, internal consistency and stability across time were: physical health $(\alpha=.84 ; r=.73, p<.001)$, psychological health $(\alpha=.74 ; r=.46, p<.05)$, social relationships $(\alpha=.68 ; r=.77$, $p<.001)$, and environment $(\alpha=.71 ; r=.26, n s)$.

PTSD. The PTSD Checklist-Civilian version (PCL-C $)^{19}$ assesses the occurrence and severity of $D S M-I V$ symptoms of PTSD in civilian populations. Respondents are asked to rate the degree to which 17 problems had bothered them in the previous month on a scale from o to 5 (a rating of 3 or more indicated endorsement of that symptom). Individuals received a PTSD diagnosis if they endorsed one or more items from Cluster B (re-experiencing), three or more items from Cluster C (avoidance and numbing), and two or more items from Cluster D (increased arousal). In this study, the scale attained high internal reliability and for the total score $(\alpha=.94)$ and for items in Cluster B $(\alpha=.89)$, Cluster C $(\alpha=.87)$ and Cluster D $(\alpha=.86)$.

Psychological distress. The Brief Symptom Inventory (BSI ${ }^{20}$ is a distress measure containing 53 items. Respondents rate how much discomfort they had experienced with certain problems in the past month. The scale produces scores on 9 symptom dimensions as well as 3 global indices. Of the global indices, the General Severity Index (GSI) was used here, indicating the current perceived distress level. The scale ranges from o to 4 , with higher scores indicating a higher level of distress. In this study, the GSI attained very good internal reliability $(\alpha=.96)$ and stability across time $(r=.87, p<.001)$.

Hostile emotions. In order to measure the behavioural manifestation of hostile emotions, we used the Anger Idioms Scale (AIS). ${ }^{21}$ This scale has 11 items, and it ranges from o to 40, higher scores indicating more hostile emotions. In this study, the alpha of the scale increased from 0.65 to 0.75 when item 11 was removed, and test-retest stability was acceptable $(r=.52, p<.01)$. Therefore, a sum score was calculated on the basis of the first 10 items of the AIs.

Culture shock. The Culture Shock Questionnaire (CSQ)22 was used in this study. It consists of 12 items ranging from 1 to 4 , with higher scores indicating a higher level of cultural shock.
(C) Author(s), 2015. This open-access work is licensed under a Creative Commons Attribution-NonCommercial 4.0 International license.
Cette oeuvre en libre accès fait l'object d'une licence Creative Commons Attribution-NonCommercial 4.0 International. 
The internal consistency of CSQ found in our study was satisfactory $(\alpha=.77)$.

\section{Sources of Support}

Family functioning. The McMaster Family Assessment Device (FAD $)^{23}$ is a 60 -item questionnaire reflecting 6 dimensions of family functioning. In addition, this tool includes 12 items that can assess the family's general functioning with no need to use all items. ${ }^{24}$ The scale ranges from 1 to 4 , with higher scores representing lower family functioning. In our sample, this scale had a Cronbach's alpha $=.60$, and testretest correlation $r=.06(n s)$.

Perceived social support. We used the 12-item Multidimensional Scale of Perceived Social Support (MSPSS) 25 to measure the degree of support from family, friends, and a significant other. The scale ranges from 1 to 7 , with higher scores indicating more support. In the current study, Cronbach's a coefficients and stability correlations for significant others, family, and friends subscales were $.86(r=.63, p<.001), .80(r=.88$, $p<.001)$ and $.82(r=.79, p<.001)$, respectively. The overall score also obtained high internal consistency $(\alpha=.90)$ and test-retest reliability $(r=.84, p<.001)$.

\section{Statistical Analysis}

Descriptive statistics were used using sPss 17.0 software. Scores for each questionnaire were calculated, provided the participant answered at least $75 \%$ of items. Regression analyses were conducted to determine factors predicting quality of life.

\section{Results}

\section{Stages 1 and 2}

\section{Pre-Migration Traumatic Events}

Table 2 presents traumatic events that had been encountered by the respondents themselves before arriving to Israel. The majority of the respondents had suffered severe traumatic events including torture, forced labour, forced separation from family, lack of food or water, lack of shelter, and burning of houses. Women reported significantly fewer traumatic events than men; however, they were significantly more likely to experience rape ( $14 \%$ of female respondents were raped and $20 \%$ sexually harassed, compared with $2 \%$ of male respondents detailing experiences of rape and $3 \%$ experiencing sexual harassment). No significant difference was found, in the number of events, between those with and without refugee status, but asylum-seekers holding a temporary A2(5)A visa were less likely to experience forced hiding, physical injury due to violence, and kidnapping. It may be that the first waves of Darfuris arriving in Israel came from Egypt after escaping violence in Sudan and Egypt,
Table 2. Pre-migration traumatic events

\begin{tabular}{|c|c|c|c|c|c|}
\hline & $\begin{array}{l}\text { Male } \\
(N= \\
276)\end{array}$ & $\begin{array}{l}\text { Female } \\
(N=64)\end{array}$ & $\begin{array}{l}\text { Has a } \\
\text { visa } \\
(\mathrm{N}= \\
58)\end{array}$ & $\begin{array}{l}\text { No visa } \\
(N= \\
282)\end{array}$ & $\begin{array}{l}\text { Total } \\
(N= \\
340)\end{array}$ \\
\hline Torture & $66 \% * *$ & $46 \% * *$ & $72 \%$ & $60 \%$ & $62 \%$ \\
\hline Imprisonment & $60 \%$ & $55 \%$ & $68 \%$ & $56 \%$ & $58 \%$ \\
\hline $\begin{array}{l}\text { Lack of food and } \\
\quad \text { water }\end{array}$ & $65 \%$ & $67 \%$ & $70 \%$ & $64 \%$ & $65 \%$ \\
\hline Forced to hide & $55 \% *$ & $38 \% *$ & $72 \% * *$ & $48 \% * *$ & $52 \%$ \\
\hline Physical assault & $72 \% * *$ & $29 \% * *$ & $70 \%$ & $64 \%$ & $65 \%$ \\
\hline $\begin{array}{l}\text { Assault with a } \\
\text { weapon }\end{array}$ & $62 \% * *$ & $41 \% * *$ & $59 \%$ & $59 \%$ & $59 \%$ \\
\hline $\begin{array}{l}\text { Forced separation } \\
\text { from family }\end{array}$ & $67 \% *$ & $50 \% *$ & $75 \%$ & $61 \%$ & $64 \%$ \\
\hline $\begin{array}{l}\text { Confiscation or } \\
\text { destruction } \\
\text { of personal } \\
\text { property }\end{array}$ & $86 \% * *$ & $66 \% * *$ & $75 \%$ & $84 \%$ & $83 \%$ \\
\hline $\begin{array}{l}\text { Combat situation/ } \\
\text { exposure to } \\
\text { war zone }\end{array}$ & $72 \%$ & $65 \%$ & $64 \%$ & $73 \%$ & $71 \%$ \\
\hline Lack of shelter & $78 \%$ & $73 \%$ & $72 \%$ & $79 \%$ & $78 \%$ \\
\hline $\begin{array}{l}\text { Serious physical } \\
\text { injury due to } \\
\text { violence }\end{array}$ & $20 \%$ & $22 \%$ & $33 \% *$ & $18 \% *$ & $20 \%$ \\
\hline $\begin{array}{l}\text { Serious illness } \\
\text { without access } \\
\text { to medical } \\
\text { care }\end{array}$ & $12 \% a$ & $2 \%^{a}$ & $11 \%^{a}$ & $10 \%{ }^{a}$ & $10 \%$ \\
\hline $\begin{array}{c}\text { Disappearance/ } \\
\text { kidnapping }\end{array}$ & $18 \%$ & $16 \%$ & $31 \% * *$ & $14 \%^{* *}$ & $17 \%$ \\
\hline $\begin{array}{l}\text { Slavery or forced } \\
\text { labour }\end{array}$ & $62 \% *$ & $45 \% *$ & $60 \%$ & $59 \%$ & $59 \%$ \\
\hline Raped & $2 \%^{a}$ & $14 \%^{a}$ & $10 \%{ }^{a}$ & $3 \%^{a}$ & $4 \%$ \\
\hline $\begin{array}{l}\text { Sexual harass- } \\
\text { ment }\end{array}$ & $3 \% a$ & $20 \%{ }^{a}$ & $11 \%{ }^{a}$ & $5 \%^{a}$ & $6 \%$ \\
\hline $\begin{array}{c}\text { Thrown from } \\
\text { a moving } \\
\text { vehicle }\end{array}$ & $15 \%$ & $8 \%$ & $10 \%$ & $14 \%$ & $13 \%$ \\
\hline $\begin{array}{l}\text { Shot by soldiers/ } \\
\text { security } \\
\text { guards/ } \\
\text { janjaweed }\end{array}$ & $68 \%$ & $57 \%$ & $63 \%$ & $67 \%$ & $66 \%$ \\
\hline House burned & $74 \%$ & $65 \%$ & $69 \%$ & $73 \%$ & $72 \%$ \\
\hline $\begin{array}{l}\text { Serious injury, } \\
\text { harm, or death } \\
\text { you caused to } \\
\text { someone else }\end{array}$ & $4 \%^{a}$ & $10 \%^{\mathrm{a}}$ & $9 \%^{a}$ & $3 \%^{a}$ & $5 \%$ \\
\hline Mean \& SD ${ }^{\mathrm{b}}$ & $8.8(4.5)^{* *}$ & $\begin{array}{l}6.4 \\
(5.2)^{* *}\end{array}$ & $\begin{array}{l}9.2 \\
(5.5)\end{array}$ & $8.1(4.5)$ & $8.3(4.7)$ \\
\hline
\end{tabular}

(C) Author(s), 2015. This open-access work is licensed under a Creative Commons Attribution-NonCommercial 4.0 International license.
Cette oeuvre en libre accès fait l'object d'une licence Creative Commons Attribution-NonCommercial 4.0 International. 
while the later waves came straight to Israel, using Egypt as a transit route, spending insignificant periods of time in that country, and thus experienced less violence.

\section{Stage 3}

\section{Living Conditions in Israel}

The majority of the respondents (98\%) lived in an urban area in Israel, either in Tel Aviv (69\%) or in Eilat (19\%), were never arrested by the police (96\%), never consumed beer (65\%), and were members of a civil organization (85\%) (not shown in the table due to small variance). In other words, although the refugees are often viewed in the public eye as likely to be engaged in criminal activities and the abuse of alcohol, the data show that they live normative lives and are socially active (see table 3).

The living conditions in Israel were not easy: the majority had relatively low economic status (mean 1.9, on a scale for 1-6). Women (mostly married and living in families supported by two salaries) and those with refugee status were significantly more likely to have a higher sEs. The majority (61\%) had no health insurance, as they can only access private health insurance. Recognized refugees were significantly more likely to hold health insurance $(82 \%)$ as they are entitled to National Security insurance and access to public health. Thus, not surprisingly, $41 \%$ of the respondents turn to a voluntary organization (Physicians for Human Rights clinic) in order to receive medical care. Of the respondents, $56 \%$ had a full-time job, and those with refugee status were more likely (66\%) to hold such a job. Men were significantly more likely than women to work in hotels and construction, and women were more likely to work in housekeeping. The majority (53\%) sent money to relatives overseas.

Most respondents had refugee friends but no Israeli friends, with men more likely to have friends than women. They tended not to be satisfied with their decision to leave Sudan (mean $=2$, on a scale of 1 to 5 ), but women and those with refugee status reported a higher level of satisfaction. However, the respondents tended to be satisfied in coming to Israel (mean $=3.5$, on a scale of $1-5)$. The respondents were not likely to master Hebrew (mean $=1.6$, on a scale from 1 to 4 ), and to present a medium level of perceived discrimination (mean $=2.3$ on a scale 1 to 4 ), with women presenting a higher level of discrimination.

\section{Living Difficulties in Israel}

Respondents had experienced many difficulties in Israel in almost all areas: worries about family members at home, access to medical care, fears of deportation, work conditions and discrimination (mean $=13.8$ difficulties on a scale from 1 to 24 ) (see table 4 ).
Women were significantly more likely to experience difficulties, including discrimination, no permission to work, not finding jobs, conflict with immigration authorities, poor access to medical care, poverty, loneliness, and separation (mean $=17.6$ difficulties among women and 13 among men). Similarly, asylum-seekers were also more likely to report difficulties as compared to their recognized refugee counterparts, including no permission to work, fears of being sent home, and poor access to medical care (mean $=14.2$ difficulties with no visa, and 12.2 with a visa).

\section{Psychological, Familial, and Social State}

The participants reported a low level of psychological symptoms, as measured by the BsI scale (mean $=0.7$, on a scale for $0-4$ ) (see table 5). Women tended to present more psychological symptoms. With respect to PTSD, $30 \%$ of the respondents suffered from this syndrome, with women significantly more likely to have a diagnosis of PTSD $(55 \%$ of women, as compared with $26 \%$ of men). This is interesting, because women suffered less traumatic events at preimmigration stage. However, they were more likely to have experienced rape and sexual harassment-dreadful events that might lead to PTSD. In addition, refugees were also more likely to have a diagnosis of PTSD than asylum-seekers ( $48 \%$ of refugees, compared with $27 \%$ of asylum-seekers). This figure corresponds to their greater exposure to traumatic events. It may also be that refugees, who are already settled down and have gained means of survival, have begun confronting their traumas while asylum-seekers were still struggling to survive.

In terms of familial relationships, applicable to those who have family members in Israel, the respondents presented an average level of family functioning (mean $=2.4$ on a scale for 1 to 4), with women showing slightly lower level of family functioning. With respect to social support, the participants presented a moderate level of support (mean $=4.6$ on a scale from 1 to 7 ), with women having significantly higher level of support (mean $=5.2$, as compared with 4.4); and asylum-seekers reporting a slightly higher support (mean $=4.7$, as compared with 4.1). In terms of cultural culture shock, respondents presented a low to moderate level of shock (mean $=2.5$ on a scale from 1 to 4 ), with women presenting a higher level of shock. In addition, the refugees tended to present low to moderate level of anger, with women presenting a slightly higher level of anger.

Finally, the respondents reported a moderate to high level of quality of life with respect to their physical health, psychological health, and social relations (means around 14 on a scale from 4 to 20). However, with respect to the environment, the score was lower $($ mean $=11.1)$, reflecting the hard living conditions of the participants in Israel in
(C) Author(s), 2015. This open-access work is licensed under a Creative Commons Attribution-NonCommercial 4.0 International license.
Cette oeuvre en libre accès fait l'object d'une licence Creative Commons Attribution-NonCommercial 4.0 International. 
Table 3. Living conditions in Israel (Mean, SD, \%)

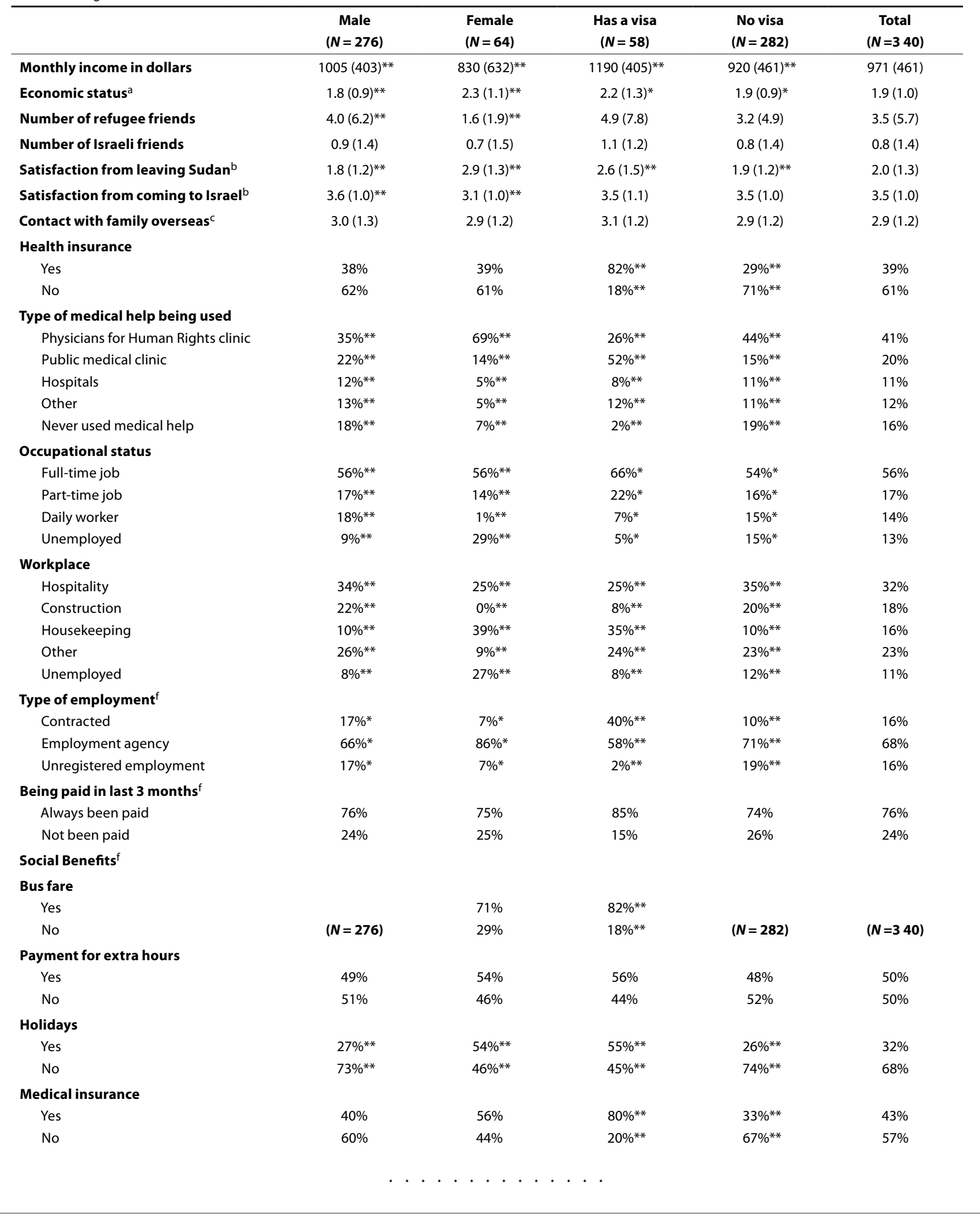

(C) Author(s), 2015. This open-access work is licensed under a

Creative Commons Attribution-NonCommercial 4.0 International license.
Cette oeuvre en libre accès fait l'object d'une licence Creative Commons Attribution-NonCommercial 4.0 International. 
Table 3 (continued)

\begin{tabular}{|c|c|c|c|c|c|}
\hline & $\begin{array}{c}\text { Male } \\
(N=276)\end{array}$ & $\begin{array}{l}\text { Female } \\
(N=64)\end{array}$ & $\begin{array}{c}\text { Has a visa } \\
(N=58)\end{array}$ & $\begin{array}{c}\text { No visa } \\
(N=282)\end{array}$ & $\begin{array}{c}\text { Total } \\
(N=340)\end{array}$ \\
\hline \multicolumn{6}{|l|}{ Compensation ${ }^{g}$} \\
\hline Yes & $9 \%$ & $9 \%$ & $27 \%$ & $5 \%$ & $9 \%$ \\
\hline No & $91 \%$ & $91 \%$ & $73 \%$ & $95 \%$ & $91 \%$ \\
\hline \multicolumn{6}{|l|}{ Pensiong } \\
\hline Yes & $7 \%$ & $3 \%$ & $29 \%$ & $1 \%$ & $6 \%$ \\
\hline No & $93 \%$ & $97 \%$ & $71 \%$ & $99 \%$ & $94 \%$ \\
\hline \multicolumn{6}{|l|}{ Social security ${ }^{g}$} \\
\hline Yes & $12 \%$ & $21 \%$ & $49 \% * *$ & $5 \% * *$ & $14 \%$ \\
\hline No & $88 \%$ & $79 \%$ & $51 \% * *$ & $95 \% * *$ & $86 \%$ \\
\hline \multicolumn{6}{|l|}{ Send money overseas } \\
\hline Yes & $60 \% * *$ & $19 \% * *$ & $48 \%$ & $53 \%$ & $53 \%$ \\
\hline No & $40 \% * *$ & $81 \% * *$ & $52 \%$ & $47 \%$ & $47 \%$ \\
\hline Proficiency in Hebrew ${ }^{d}$ & $1.7(0.6)$ & $1.6(0.5)$ & $1.9(0.7)^{* *}$ & $1.6(0.6)^{* *}$ & $1.6(0.6)$ \\
\hline Perceived Discrimination ${ }^{\mathrm{e}}$ & $2.2(1.0)^{* * *}$ & $2.9(0.9)^{* *}$ & $2.4(1.0)$ & $2.3(1.0)$ & $2.3(1.0)$ \\
\hline \multicolumn{6}{|c|}{ Where see oneself settled in 5 years ${ }^{g}$} \\
\hline In Israel & $5 \%$ & $9 \%$ & $12 \%$ & $4 \%$ & $6 \%$ \\
\hline In Darfur, only if there is peace & $59 \%$ & $66 \%$ & $57 \%$ & $61 \%$ & $60 \%$ \\
\hline In Darfur, anyway & $4 \%$ & $8 \%$ & $4 \%$ & $5 \%$ & $5 \%$ \\
\hline Resettled in another country & $15 \%$ & $11 \%$ & $18 \%$ & $14 \%$ & $14 \%$ \\
\hline Don't know & $17 \%$ & $6 \%$ & $9 \%$ & $16 \%$ & $15 \%$ \\
\hline
\end{tabular}

a1 to 6, higher scores indicating better economic status

b1 to 5 , higher scores indicating greater satisfaction

' 1 to 7 , higher scores indicating higher frequency

$d_{1}$ to 4 , higher scores indicating better Hebrew proficiency

e 1 to 4 , higher scores indicating worse perceived discrimination

${ }^{f}$ For those who are employed

gIn some cells, expected frequencies were too low to compute chi-squared test

${ }^{*} p<.05 .{ }^{* *} p<.01$

terms of financial resources, housing, and health. Women reported a lower level of physical and psychological quality of life, a finding that is in accordance with their overall lower level of socio-psychological state. Also, recognized refugees were more likely to report a lower level of physical health and social relations.

\section{Predictors of Quality of Life}

To model the predictors of quality of life, we conducted a series of hierarchical regressions. These analyses examined the relative contributions of gender, legal status, perceived discrimination, PTSD diagnosis, and post-migration living difficulties on the 4 domains of quality of life described above. For each domain outcome: gender and legal status were entered at step 1; post-migration living difficulties, PTSD diagnosis, and perceived discrimination were entered at step 2 (see table 6). The predictors were chosen on the basis of previous bi-variant analyses suggesting that they are related to the dependent variable. In addition, these predictors come from the 4 domains of the ecological systems theory: gender and PTSD's diagnosis belong to the micro-system, perceived discrimination belongs to the meso-system, and living difficulties and legal status belong to the exo-system as well as to the macro-system.

Physical health. At step 1, a model containing gender and legal status significantly predicted physical health: $F(2,251)$ $=8.43, p<0.001$, accounting for $6.3 \%$ of the variance. Both gender and legal status were important factors, with males and visa holders reporting better quality of life with regard to physical health. When PTSD diagnosis, perceived discrimination, and living difficulties were added at step 2, a further $31.6 \%$ of the variance was accounted for: $F_{c h}(3,248)=42.01$, $p<0.001$, with PTSD diagnosis and perceived discrimination making a significant and unique contribution. Participants who did not meet the criteria for PTSD and those who had lower levels of perceived discrimination also reported better quality of physical health. Gender was no longer significant,
(C) Author(s), 2015. This open-access work is licensed under a Creative Commons Attribution-NonCommercial 4.0 International license.
Cette oeuvre en libre accès fait l'object d'une licence Creative Commons Attribution-NonCommercial 4.0 International. 
Table 4. Post-migration living difficulties (serious/very serious problems)

\begin{tabular}{|c|c|c|c|c|c|}
\hline & $\begin{array}{l}\text { Male } \\
(N= \\
276)\end{array}$ & $\begin{array}{l}\text { Fe- } \\
\text { male } \\
(N= \\
64)\end{array}$ & $\begin{array}{l}\text { Has a } \\
\text { visa } \\
(N= \\
58)\end{array}$ & $\begin{array}{l}\text { No } \\
\text { visa } \\
(N= \\
282)\end{array}$ & $\begin{array}{l}\text { Total } \\
(N= \\
340)\end{array}$ \\
\hline \multicolumn{6}{|l|}{ Communication } \\
\hline difficulties & $15 \% * *$ & $49 \% * *$ & $20 \%$ & $22 \%$ & $21 \%$ \\
\hline Discrimination & $62 \% * *$ & $85 \% * *$ & $66 \%$ & $66 \%$ & $66 \%$ \\
\hline Separation from family & $75 \%$ & $82 \%$ & $73 \%$ & $77 \%$ & $76 \%$ \\
\hline \multicolumn{6}{|l|}{ Worries about family } \\
\hline back at home & $91 \%$ & $97 \%$ & $89 \%$ & $93 \%$ & $92 \%$ \\
\hline \multicolumn{6}{|l|}{ Unable to return home } \\
\hline in emergency & $85 \%$ & $92 \%$ & $80 \%$ & $87 \%$ & $86 \%$ \\
\hline No permission to work & $55 \% * *$ & $78 \% * *$ & $40 \% * *$ & $63 \% * *$ & $59 \%$ \\
\hline Not able to find work & $49 \% * *$ & $79 \% * *$ & $42 \%$ & $56 \%$ & $54 \%$ \\
\hline Bad job conditions & $53 \% * *$ & $82 \% * *$ & $54 \%$ & $60 \%$ & $59 \%$ \\
\hline Being in detention & $29 \% * *$ & $74 \% * *$ & $40 \%$ & $37 \%$ & $37 \%$ \\
\hline \multicolumn{6}{|l|}{ Interviews by } \\
\hline immigration & $16 \% * *$ & $58 \% * *$ & $31 \%$ & $22 \%$ & $24 \%$ \\
\hline \multicolumn{6}{|l|}{ Delays in processing } \\
\hline visa application & $27 \% * *$ & $61 \% * *$ & $38 \%$ & $32 \%$ & $34 \%$ \\
\hline \multicolumn{6}{|l|}{ Conflict with immigra- } \\
\hline \multicolumn{6}{|l|}{ Fears of being sent } \\
\hline home & $81 \%$ & $80 \%$ & $67 \% * *$ & $84 \% * *$ & $81 \%$ \\
\hline $\begin{array}{l}\text { Worries about not get- } \\
\text { ting medical care }\end{array}$ & $64 \% *$ & $77 \% *$ & $46 \% * *$ & $71 \% * *$ & $67 \%$ \\
\hline $\begin{array}{l}\text { Poor access to emer- } \\
\text { gency medical care }\end{array}$ & $58 \% * *$ & $80 \% * *$ & $52 \%$ & $64 \%$ & $62 \%$ \\
\hline \multicolumn{6}{|l|}{ Poor access to long- } \\
\hline \multicolumn{6}{|l|}{ Poor access to dentistry } \\
\hline care & $59 \% *$ & $64 \% *$ & $54 \%$ & $63 \%$ & $62 \%$ \\
\hline \multicolumn{6}{|l|}{ Poor access to counsel- } \\
\hline ling services & $60 \%$ & $65 \%$ & $33 \% * *$ & $67 \% * *$ & $61 \%$ \\
\hline \multicolumn{6}{|l|}{ Little government help } \\
\hline with welfare & $58 \%$ & $70 \%$ & $46 \% *$ & $63 \% *$ & $60 \%$ \\
\hline \multicolumn{6}{|l|}{ Little help with welfare } \\
\hline from charities & $58 \%$ & $71 \%$ & $51 \% *$ & $63 \%$ & $61 \%$ \\
\hline Poverty & $75 \% *$ & $87 \% *$ & $71 \%$ & $79 \%$ & $77 \%$ \\
\hline \multicolumn{6}{|l|}{ Loneliness and } \\
\hline boredom & $63 \% * *$ & $85 \% \%^{* *}$ & $71 \%$ & $67 \%$ & $68 \%$ \\
\hline Isolation & $60 \% * *$ & $82 \% * *$ & $74 \%$ & $62 \%$ & $64 \%$ \\
\hline \multicolumn{5}{|l|}{ Poor access to the } & $39 \%$ \\
\hline Mean \& $S D^{b}$ & $\begin{array}{l}13.0 \\
(5.3)^{* *}\end{array}$ & $\begin{array}{l}17.6 \\
(5.7)^{* *}\end{array}$ & $\begin{array}{l}12.2 \\
(6.2)^{*}\end{array}$ & $\begin{array}{l}14.2 \\
(5.5)^{*}\end{array}$ & $\begin{array}{l}13.8 \\
(5.7)\end{array}$ \\
\hline
\end{tabular}

axpected cell frequencies too low

$b_{1}$ to 24 , higher scores indicating more problems

${ }^{*} p<.05 .{ }^{* *} p<.01$
Table 5. Psychological, familial, and social state (Mean, SD, \%)

\begin{tabular}{|c|c|c|c|c|c|}
\hline & $\begin{array}{l}\text { Male } \\
(N= \\
276)\end{array}$ & $\begin{array}{l}\text { Female } \\
(N=64)\end{array}$ & $\begin{array}{l}\text { Has a } \\
\text { visa } \\
(N=58)\end{array}$ & $\begin{array}{l}\text { No visa } \\
(N= \\
282)\end{array}$ & $\begin{array}{l}\text { Total } \\
(N= \\
340)\end{array}$ \\
\hline BSI ${ }^{a}$ & & & & & 0.7 \\
\hline Somatization & & & & & $(0.7)$ \\
\hline Obsessive- & & & & & 0.4 \\
\hline compulsive & & & & & (0.6) \\
\hline Interpersonal & & & & & 0.8 \\
\hline sensitivity & & & & & $(0.9)$ \\
\hline Depression & & & & & 0.9 \\
\hline Anxiety & & & & & $(1.0)$ \\
\hline Hostility & $0.7(0.7)^{*}$ & & & & 1.0 \\
\hline Phobic anxiety & $0.3(0.6)^{*}$ & & & & (0.9) \\
\hline Paranoid & $0.8(0.9)$ & $0.9(0.6)^{*}$ & $0.8(0.7)$ & $0.7(0.7)$ & 0.7 \\
\hline ideation & $0.9(1.0)$ & $0.5(0.7)^{*}$ & $0.4(0.6)$ & $0.4(0.6)$ & $(0.8)$ \\
\hline \multirow[t]{8}{*}{ Psychoticism } & $1.0(0.9)$ & $1.0(0.8)$ & $1.0(1.0)$ & $0.8(1.0)$ & 0.4 \\
\hline & 0.6 & $1.1(1.0)$ & $1.1(1.0)$ & $0.9(1.0)$ & $(0.7)$ \\
\hline & $(0.8)^{* * *}$ & $1.1(0.9)$ & $1.1(0.9)$ & $1.0(0.9)$ & 0.6 \\
\hline & $0.4(0.7)$ & $1.0(0.8)^{* *}$ & $0.8(0.8)$ & $0.7(0.8)$ & $(0.7)$ \\
\hline & 0.5 & $0.6(0.7)$ & $0.6(0.8)^{*}$ & $0.4(0.6)^{*}$ & 1.1 \\
\hline & $(0.7)^{* *}$ & $0.8(0.7)^{* *}$ & $0.6(0.7)$ & $0.6(0.7)$ & $(0.8)$ \\
\hline & $1.1(0.8)$ & $1.1(0.8)$ & $1.2(0.8)$ & $1.0(0.8)$ & 0.6 \\
\hline & $0.5(0.7)$ & $0.7(0.7)$ & $0.8(0.8)^{*}$ & $0.5(0.7)^{*}$ & $(0.7)$ \\
\hline WHOQOL- & & & 13.8 & 15.1 & 14.9 \\
\hline BREF $^{\mathrm{b}}$ & & & $(3.5)^{*}$ & $(3.0)^{*}$ & (3.1) \\
\hline Physical health & 15.1 & 13.9 & 14.3 & 14.5 & 14.5 \\
\hline Psychological & $(3.2)^{* *}$ & $(2.6)^{* *}$ & (3.3) & $(2.8)$ & (2.8) \\
\hline health & 14.9 & 12.6 & 13.4 & 14.3 & 14.2 \\
\hline Social & $(2.5)^{* * *}$ & $(3.4)^{* * *}$ & $(3.4)^{*}$ & $(2.8)^{*}$ & (3.0) \\
\hline relationships & $14.2(3.0)$ & $14.3(2.7)$ & 11.3 & 11.1 & 11.1 \\
\hline Environment & $11.1(2.3)$ & $11.3(8.2)$ & $(3.1)$ & (4.3) & $(4.1)$ \\
\hline \multicolumn{6}{|l|}{ PTSD diagnosis } \\
\hline No & $74 \% \%^{* *}$ & $45 \% * *$ & $52 \% * *$ & $73 \% \%^{* * *}$ & $70 \%$ \\
\hline Yes & $26 \% * *$ & $55 \% * *$ & $48 \% * *$ & $27 \% * *$ & $30 \%$ \\
\hline \multirow[t]{2}{*}{ FAD $^{C}$} & 2.4 & & & & 2.4 \\
\hline & $(0.1)^{* *}$ & $2.5(0.2)^{* *}$ & $2.4(0.1)$ & $2.4(0.1)$ & $(0.1)$ \\
\hline \multirow[t]{2}{*}{ MSPSS $^{d}$} & 4.4 & & 4.1 & 4.7 & 4.6 \\
\hline & $(1.1)^{* *}$ & $5.2(1.0)^{* *}$ & $(1.3)^{* *}$ & $(1.1)^{* *}$ & $(1.2)$ \\
\hline \multirow[t]{2}{*}{ Culture Shock $^{\mathrm{e}}$} & 2.4 & & & & 2.5 \\
\hline & $(0.4)^{* *}$ & $2.7(0.4)^{* *}$ & $2.5(0.4)$ & $2.5(0.5)$ & $(0.4)$ \\
\hline Anger Idioms & 20.0 & 22.0 & 20.3 & 20.4 & 20.4 \\
\hline Scale $^{f}$ & $(4.2)^{* *}$ & $(4.4)^{* * *}$ & $(4.4)$ & (4.3) & $(4.3)$ \\
\hline \multicolumn{6}{|c|}{$\begin{array}{l}\text { aBrief Symptom Inventory, o to } 4 \text {, higher scores indicat } \\
\text { logical distress }\end{array}$} \\
\hline \multicolumn{6}{|c|}{$\mathrm{b}_{4}$ to 20 , higher scores indicating better quality of life } \\
\hline \multicolumn{6}{|c|}{$\begin{array}{l}\text { 'Family Assessment Device, } 1 \text { to } 4 \text {, higher scores indicating worse family } \\
\text { functioning }\end{array}$} \\
\hline \multicolumn{6}{|c|}{${ }^{\mathrm{d}}$ Multidimensional Scale of Perceived Social Support, 1 to 7, higher scores } \\
\hline \multicolumn{6}{|c|}{ indicating better perceived social support } \\
\hline \multicolumn{6}{|c|}{$e_{1}$ to 4 , higher scores indicating a higher level of culture shock } \\
\hline $\begin{array}{l}\text { fo to } 40, \text { higher sco } \\
{ }^{*} p<.05 .{ }^{* *} p<.01\end{array}$ & es indicatir & g more host & ile emotion & & \\
\hline
\end{tabular}

(C) Author(s), 2015. This open-access work is licensed under a

Creative Commons Attribution-NonCommercial 4.0 International license.
Cette oeuvre en libre accès fait l'object d'une licence Creative Commons Attribution-NonCommercial 4.0 International. 
Table 6. Hierarchical multiple linear regressions predicting physical health, psychological health, social relationship, and environment

\begin{tabular}{|c|c|c|c|c|}
\hline & \multicolumn{4}{|c|}{ Domains of quality of life } \\
\hline & Physical health & Psychological health & Social relationship & Environment \\
\hline \multicolumn{5}{|l|}{ Predictor } \\
\hline Step 1 & $\beta$ & $\beta$ & $\beta$ & $\beta$ \\
\hline Gender & $-.14^{*}$ & $-.23^{* * *}$ & .03 & -.08 \\
\hline Legal status & $.21^{* *}$ & .05 & .07 & -.07 \\
\hline$R^{2}$ & $.063^{* * *}$ & $.056^{* *}$ & .006 & .012 \\
\hline \multicolumn{5}{|l|}{ Step 2} \\
\hline Gender & -.01 & -.10 & 11 & .05 \\
\hline Legal status & $.14^{* *}$ & -.00 & .02 & -.05 \\
\hline PTSD diagnosis & $-.40^{* * *}$ & $-.29 * * *$ & $-.27^{* * *}$ & .03 \\
\hline Perceived discrimination & $-.30 * * *$ & $-.38^{* * *}$ & $-.15^{*}$ & $-.24^{* * *}$ \\
\hline Post-migration living difficulties & -.02 & -.05 & -.00 & $-.38^{* * *}$ \\
\hline$\Delta R^{2}$ & $.316^{* * *}$ & $.308^{* * *}$ & $.117^{* * *}$ & $.252^{* * *}$ \\
\hline$N$ & 254 & 251 & 254 & 254 \\
\hline
\end{tabular}

Gender: 0 = male, $1=$ female; Legal status: 0 = asylum seeker, 1 = refugee; PTSD: 0 = no PTSD, 1 = has PTSD; Perceived discrimination: higher scores indicating higher levels of perceived discrimination; Post-migration living difficulties: higher scores indicating more problems; Quality of life: higher scores indicating better quality of life.

${ }^{*} p<.05 ;{ }^{* *} p<.01 ;{ }^{* * *} p<.001$

but legal status was still important. The overall model was significant: $F(5,248)=30.23, p<0.001$, accounting for $37.9 \%$ of the variance in physical health scores.

Psychological health. At step 1, a model containing both gender and legal status significantly predicted psychological health: $F(2,248)=7.30, p<0.01$, accounting for $5.6 \%$ of the variance. Gender was the only significant variable, as males in this sample reported better quality of psychological health, compared with females. Inclusion of PTSD diagnosis, perceived discrimination, and living difficulties at step 2 produced a significant $30.8 \%$ increment in variance accounted for: $F_{\mathrm{ch}}(3,245)=39.61, p<0.001$, with PTSD diagnosis and perceived discrimination making a significant and unique contribution. Participants who did not meet the criteria for PTSD and those who had lower levels of perceived discrimination also reported better quality of psychological health. Gender made a unique contribution only at $p=0.07$. The overall model was significant: $F(5,245)=28.05, p<0.001$, accounting for $36.4 \%$ of the variance in psychological health scores.

Social relationships. At Step 1, a model containing gender and age did not account for significant variance in predicting social relationships: $F(2,251)<1.00, F(2,251)<1.00$, explaining only $0.6 \%$ of the variance. At step 2, PTSD diagnosis, perceived discrimination and living difficulties were entered and the model accounted for an additional $11.7 \%$ of the variance:
$F_{\mathrm{ch}}(3,248)=11.04, p<0.001$, with PTSD diagnosis and perceived discrimination making a significant and unique contribution. Participants who did not meet the criteria for PTSD and those who had lower levels of perceived discrimination reported better quality of social relationships. Gender also made a unique contribution at $p=0.07$. The overall model was significant: $F(5,248)=6.98, p<0.001$, accounting for $12.3 \%$ of the variance in social relationships scores.

Environmental factors. At step 1, a model containing gender and legal status did not account for significant variance in predicting environmental scores: $F(2,251)=1.6,(n s)$, explaining only $1.2 \%$ of the variance. At step 2, PTSD diagnosis, perceived discrimination, and post-migration living difficulties were entered and the model accounted for an additional $25.2 \%$ of the variance: $F_{\mathrm{ch}}(3,248)=28.27, p<0.001$. Perceived discrimination and living difficulties emerged as the only significant predictors. Participants with lower levels of perceived discrimination and fewer living difficulties reported better quality quality life in the domain of environment. The overall model was significant: $F(5,248)=17.78, p<0.001$, accounting for $26.4 \%$ of the variance in environment scores.

\section{Discussion}

In this study, we present a profile of Darfuri refugees and asylum-seekers in Israel according to 4 stages in the participants' journey and we analyze their quality of life according to 4 domains: physical health, psychological health, social
(C) Author(s), 2015. This open-access work is licensed under a Creative Commons Attribution-NonCommercial 4.0 International license.
Cette oeuvre en libre accès fait l'object d'une licence Creative Commons Attribution-NonCommercial 4.0 International. 
relationship, and environmental factors, and tried to predict these domains using individual and social factors.

The first and second stages consider the period before and during the war and displacement, respectively. The vast majority of the participants experienced a high rate of severe pre-migration traumas in stages 1 and 2, including lack of shelter and food, being in combat, separation from family, exposure to slavery, imprisonment, and torture.

The high rates of trauma exposure found here are greater than those shown in a study among Sudanese and Eritrean refugees in Israel. ${ }^{26}$ This difference may be attributed to different migration periods: the report by Nakash et al. focused on traumatic events during transit to Israel via the Sinai desert, whereas our research referred to traumas experienced mostly before migration, presumably, in the war zone or in Khartoum. Indeed, the extant of war-related traumatic exposure in our study is consistent with that previously reported among Darfuri refugees ${ }^{27}$ and among other populations of displaced refugees. ${ }^{28}$

Women demonstrated fewer overall traumatic events but were at greater risk of experiencing sexual violence. This pattern is consistent with prior research of gender differences in reports of traumatic events. ${ }^{29}$ The overall levels of trauma reported by holders of temporary visas and those without it were similar, although the former group who arrived earlier did report more personal experiences of physical injury, disappearance, and being forced to hide.

The third stage examined living conditions and mental state throughout post-migration period. Despite the trauma, participants were able to manage regular daily life, as apparent from their high employment rates (87\%), which are above that reported among Darfuri refugees living in camps $(21.9 \%),{ }^{30}$ and higher than the prevalence of $23.8 \%^{31}$ and $39.0 \%{ }^{32}$ for Sudanese refugees resettled in Australia and Canada, respectively.

There were no significant differences between refugees and asylum-seekers in age, marital status, levels of education, and residency in Sudan. The two groups also exhibited similar levels of culture shock and psychological distress. As expected, asylum-seekers had stayed in Israel for shorter lengths of time, but also reported shorter periods since departure, meaning that they had not been displaced in other countries for any significant periods, while those recognized as refugees did spend a significant period in Egypt before deciding to move across the border into Israel.

Recognized refugees had higher rates of PTSD than asylum-seekers. This finding is interesting, as the two groups did not differ in the number of pre-migration traumatic events that were experienced. The finding is also inconsistent with previous reports that show that individuals with less protective residency status are more vulnerable to PTSD. 33
This discrepancy may result from the fact that the studies of Steel and colleagues compared temporary and permanent visas holders. In contrast, in our study all participants suffered from insecure residency, as Israeli asylum policy keeps changing and thus did not provide long-term security, even for those recognized as refugees. In addition, recognized refugees are less likely to struggle with daily financial survival in Israel, as compared with asylum-seekers. It may be that when the struggle to survive is lessened, psychological symptoms and PTSD are more likely to surface. Another explanation may be related to the period of residency in Egypt for the group of refugees, where they might have faced significant stressors that had not been reported in the pre-migration traumatic events. ${ }^{34}$ Another explanation involves variables that may serve as protective factors against PTSD: high levels of religiosity 35 and perceived social support,${ }^{36}$ which were more pronounced in the group of asylum-seekers than among the refugees.

Women were significantly younger than men, mostly married with children, and had lower levels of education. Compared to men, women had more negative outcomes on most psychological measures: higher levels of perceived discrimination, greater psychological distress, increased prevalence of PTSD, poorer family functioning, higher levels of culture shock, and elevated hostile emotions. The finding that women display greater levels of PTSD compared with men is consistent with previous research suggesting sex differences in vulnerability to PTSD. ${ }^{37}$

The study also examined predictors of quality of life. The results revealed that perceived discrimination played a significant role in perceived quality of life, as participants with high levels of perceived discrimination reported reduced quality of life. PTSD diagnosis was also a strong predictor of quality of life: participants who met the criteria for PTSD were at greater risk for poor quality of life, even after taking gender and living difficulties into account. Gender made a unique contribution to the prediction of quality of life: women were more likely than men to suffer from poor quality of life. However, when PTSD diagnosis, perceived discrimination, and living difficulties were added to the model, gender was not longer a significant predictor of life quality measures. This suggests that gender differences in quality of life might be due to women's higher scores on PTSD, perceived discrimination, and living difficulties. Similarly, legal status also had a significant effect on quality of life, which was also reduced after statistically controlling for PTSD, perceived discrimination, and living difficulties. Finally, difficulties in post-migration living were the strongest predictor of quality of life in the environmental domain: fewer difficulties increased the quality of life with regard to the environment.
(C) Author(s), 2015. This open-access work is licensed under a Creative Commons Attribution-NonCommercial 4.0 International license.
Cette oeuvre en libre accès fait l'object d'une licence Creative Commons Attribution-NonCommercial 4.0 International. 
The study has a number of limitations. The use of snowball sampling methods may have induced a selection bias and hindered our ability to generalize these findings. However, we believe that our sample is representative of the generality of Darfuris in Israel, based on the heterogeneity found in respondents' demographic characteristics and our use of several geographic locations and ethnic variety. Another limitation is the use of retrospective reports to assess exposure to traumatic events. Such measures are susceptible to recall bias due to memory deficiencies and retrospective interpretation and may hinder the reliability of our findings. Also, the participants may have tended to exaggerate when reporting on their conditions to rationalize a claim for refugee status. Finally, our study focused on a single refugee population, which limits the ability to generalize our findings to other groups of asylum-seekers living in Israel. ${ }^{38}$

In sum, the Darfuris in this study demonstrated high frequencies of pre-migration traumatic exposure and serious post-migration living difficulties. These stressors were accompanied by high prevalence of PTSD. Thus, these findings have important implications for governmental immigration policies and for social practitioners. For the Israeli government, temporary protected groups like the Sudanese asylum seekers should have access to RSD. Moreover, those matching the requirements set by the Refugee Convention 1951 should gain all its entitlements, including access to employment and health care. Counselling services need to be provided to women and men who are survivors of sexual and gender-based violence and those suffering from PTSD. A clear policy and a suitable legislation have to be developed by the Israeli government that is based on rights and entitlements rather than deterrence and exclusion. The constantly changing policies contribute to the levels of stress and insecurity of asylum-seekers and eventually lead to increased levels of vulnerability in a population with few rights but many needs. Many of the respondents are still in detention at the Hollot detention centre and are unable to continue with normal lives. It is the duty of the Israeli government to provide these survivors with psychological help and dignified life in security.

Vered Slonim-Nevo is a professor of social work at the Spitzer Department of Social Work, Ben Gurion University of the Negev. Her research areas include immigration, refugees and asylum-seekers, clinical counselling, families, and child welfare. The author may be contacted at slonim@bgu.ac.il.

Shirley Regev is a PhD graduate from the Department of Psychology at Ben-Gurion University. She is a research fellow at the School of Psychology, Queen's University Belfast. The author may be contacted at S.Dorchin-Regev@qub.ac.uk.
Yiftach Millo is an international consultant on refugee protection serving as field coordinator for HIAS SGBV affecting atrisk refugee populations in Chad, Kenya, South Africa, and Uganda. The author may be contacted atymillo@gmail.com.

\section{Notes}

1 Susan M. Meffert and Charles R. Marmar, "Darfur Refugees in Cairo Mental Health and Interpersonal Conflict in the Aftermath of Genocide," Journal of Interpersonal Violence 2, no. 2 (2009): 1835-48; Kathrin Stoll and Phyllis Johnson, "Determinants of the Psychosocial Adjustment of Southern Sudanese Men," Journal of Refugee Studies 20, no. 4 (2007): 621-40.

2 Martin Timothy Rowe, The Experience of Protest: Masculinity and Agency among Sudanese Refugees in Cairo (Cairo: American University in Cairo Press, 2009).

3 "Israeli Law No. 5712-1952, Entry into Israel Law," 1952, http://www.refworld.org/docid/3ae6b4eco.html.

4 Population, Immigration and Borders Authority (PIBA), "Data on Foreigners in Israel: Summary for 2013," 2014, http://www.piba.gov.il/PublicationAndTender/ForeignWorkersStat/Documents/563343n8o.pdf.

5 Yaron Hadas, Nurit Hashimshony-Yaffe, and John Campbell, “'Infiltrators' or Refugees? An Analysis of Israel's Policy towards African Asylum-Seekers.” International Migration 51, no. 4 (2013): 144-57.

6 Shira Lawrence, "Anti-Infiltration Bill Passes into Law," African Refugee Development Center (ARDC), 2014, http:// ardc-israel.org/en/article/anti-infiltration-bill-passes-law.

7 Ilan Lior, "The End of the Strike of the Refugees from Africa: More than 1000 Were Incarcerated," Haaretz, 1 December 2014, http://www.haaretz.co.il/news/education/1.2215381; Lior, "The Supreme Court Declared That Hollot Should Be Closed in 9o Days," Haaretz, 12 September 2014, http://www.haaretz.co.il/news/law/1.2438172; Lior, "The Government Ignores the Supreme Court Decision and Continues to Call Asylum Seekers to Hollot," Haaretz, 29 September 2014, http://www.haaretz.co.il/ news/education/.premium-1.2445354.

8 Yuval Goren, "Humanitarian Organization: More than 22 Refugees That Were Deported to Sudan Died This Year," 6 May 2013, http://www.nrg.co.il/online/1/ART2/477/197 .html.

9 Barak Ravid and Ilan Lior, "Court Invalidates Legislation Allowing Israel to Detain Migrants without Trial," Haaretz, 16 September 2014, http://www.haaretz.com/ news/diplomacy-defense/.premium-1.547311.

10 "In the Nick of Time, Knesset Passes Amended AntiInfiltration Law," i24 News, 9 December 2014, http:// www.i24news.tv/app.php/en/news/israel/politics/53858141209-israel-parliament-passes-new-law-against-illegalmigrants.
(C) Author(s), 2015. This open-access work is licensed under a Creative Commons Attribution-NonCommercial 4.0 International license.
Cette oeuvre en libre accès fait l'object d'une licence Creative Commons Attribution-NonCommercial 4.0 International. 
11 Alastair Ager, "Video Lecture and Transcript: Responding to the Psychosocial Needs of Refuge," 2007, http://www. forcedmigration.org/rfgexp/pdfs/1_2.pdf.

12 Lord Clinton-Davis and Yohannes Fassil, "Health and Social Problems of Refugees," Social Science \& Medicine 35, no. 4 (1992): 507-13; Ora Nakash, Benjamin Langer, Maayan Nagar, Shahar Shoham, Ido Lurie, and Nadav Davidovitch, "Exposure to Traumatic Experiences among Asylum Seekers from Eritrea and Sudan during Migration to Israel," Journal of Immigrant and Minority Health 17, no. 4 (2014): 1280-6.

13 Ibid., 11.

14 Ibid., 12; Paul Cambridge and Lucy Williams, "Approaches to Advocacy for Refugees and Asylum Seekers: A Development Case Study for a Local Support and Advice Service," Journal of Refugee Studies 17, no. 1 (2004): 97-113; and Katrine Fangen, "Humiliation Experienced by Somali Refugees in Norway," Journal of Refugee Studies 19, no. 1 (2006): 69-93.

15 Urie Bronfenbrenner, "Ecology of the Family as a Context for Human Development: Research Perspectives," Developmental Psychology 22, no. 6 (1986): 723.

16 Richard F. Mollica, Yael Caspi-Yavin, Paola Bollini, Toan Truong, Svang Tor, and James Lavelle, "The Harvard Trauma Questionnaire: Validating a Cross-Cultural Instrument for Measuring Torture, Trauma, and Posttraumatic Stress Disorder in Indochinese Refugees," Journal of Nervous and Mental Disease 180, no. 2 (1992): 111-16.

17 Derrick Silove, Z. Steel, P. McGorry, and P. Mohan, "Trauma Exposure, Post-Migration Stressors, and Symptoms of Anxiety, Depression and Post-traumatic Stress in Tamil Asylum-Seekers: Comparison with Refugees and Immigrants," Acta Psychiatrica Scandinavica 97, no. 3 (1998): 175-181; and Zachary Steel, Derrick Silove, Kevin Bird, Patrick McGorry, and P. Mohan, "Pathways from War Trauma to Posttraumatic Stress Symptoms among Tamil Asylum Seekers, Refugees, and Immigrants," Journal of Traumatic Stress 12, no. 3 (1999): 421-35.

18 WHOQOL Group, "Development of the World Health Organization WHOQOL-BREF Quality of Life Assessment," Psychological Medicine 28, no. 3 (1998): 551-8.

19 F. W. Weathers, B.T. Litz, D. Herman, J. Huska, and T. Keane, "The PTSD Checklist-Civilian Version (PCL-C)" (Boston, MA: National Center for PTSD, 1994).

20 Leonard R. Derogatis and Nick Melisaratos, "The Brief Symptom Inventory: An Introductory Report," Psychological Medicine 13, no. 03 (1983): 595-605.

21 Robert G. Malgady, Lloyd H. Rogler, and Dharma E. Cortés, "Cultural Expression of Psychiatric Symptoms: Idioms of Anger among Puerto Ricans," Psychological Assessment 8, no. 3 (1996): 265-8.

22 D.B. Mumford, "The Measurement of Culture Shock," Social Psychiatry and Psychiatric Epidemiology 33, no. 4 (1998): 149-54.
23 Nathan B. Epstein, Lawrence M. Baldwin, and Duane S. Bishop, "The McMaster Family Assessment Device," Journal of Marital and Family Therapy 9, no. 2 (1983): 171-80.

24 Ty A. Ridenour, James Daley, and Wendy Reich, "Factor Analyses of the Family Assessment Device," Family Process 38, no. 4 (1999): 497-510.

25 Gregory D. Zimet, Nancy W. Dahlem, Sara G. Zimet, and Gordon K. Farley, "The Multidimensional Scale of Perceived Social Support," Journal of Personality Assessment 52, no. 1 (1988): 30-41.

26 Robert G. Malgady, Lloyd H. Rogler, and Dharma E. Cortés, "Cultural Expression of Psychiatric Symptoms: Idioms of Anger among Puerto Ricans," Psychological Assessment 8, no. 3 (1996): 265-8.

27 Alia Badri, Rik Crutzen, and H. W. Van den Borne, "Exposures to War-Related Traumatic Events and Post-traumatic Stress Disorder Symptoms among Displaced Darfuri Female University Students: An Exploratory Study," BMC Public Health 12, no. 1 (2012): 603.

28 Kamaldeep Bhui, Abdisalama Abdi, Mahad Abdi, Stephen Pereira, Mohammed Dualeh, David Robertson, Ganesh Sathyamoorthy, and Hellena Ismail, "Traumatic Events, Migration Characteristics and Psychiatric Symptoms among Somali Refugees," Social Psychiatry and Psychiatric Epidemiology 38, no. 1 (2003): 35-43; and Sharon S. Tang and Steven H. Fox, "Traumatic Experiences and the Mental Health of Senegalese Refugees," Journal of Nervous and Mental Disease 189, no. 8 (2001): 507-12.

29 David F. Tolin and Edna B. Foa. "Sex Differences in Trauma and Posttraumatic Stress Disorder: A Quantitative Review of 25 Years of Research," Psychological Bulletin 132, no. 6 (2006): 959.

30 Andrew Rasmussen, Leanh Nguyen, John Wilkinson, Sikhumbuzo Vundla, Sumithra Raghavan, Kenneth E. Miller, and Allen S. Keller, "Rates and Impact of Trauma and Current Stressors among Darfuri Refugees in Eastern Chad," American Journal of Orthopsychiatry 80, no. 2 (2010): 227-36.

31 Robert Schweitzer, Fritha Melville, Zachary Steel, and Philippe Lacherez, "Trauma, Post-Migration Living Difficulties, and Social Support as Predictors of Psychological Adjustment in Resettled Sudanese Refugees," Australian and New Zealand Journal of Psychiatry 40, no. 2 (2006): 179-88.

32 Laura Simich, Hayley Hamilton, and B. Khamisa Baya, "Mental Distress, Economic Hardship and Expectations of Life in Canada among Sudanese Newcomers," Transcultural Psychiatry 43, no. 3 (2006): 418-44.

33 Angela Nickerson, Zachary Steel, Richard Bryant, Robert Brooks, and Derrick Silove, "Change in Visa Status amongst Mandaean Refugees: Relationship to Psychological Symptoms and Living Difficulties," Psychiatry Research 187, no. 1 (2011): 267-74; and Zachary Steel, Derrick Silove, Robert Brooks, Shakeh Momartin, Bushra Alzuhairi, and I. N. A.
(C) Author(s), 2015. This open-access work is licensed under a Creative Commons Attribution-NonCommercial 4.0 International license.
Cette oeuvre en libre accès fait l'object d'une licence Creative Commons Attribution-NonCommercial 4.0 International. 
Susljik, "Impact of Immigration Detention and Temporary Protection on the Mental Health of Refugees," British Journal of Psychiatry 188, no. 1 (2006): 58-64.

34 Ibid., 30.

35 Jacob Bentley, Zeba Ahmad, and John Thoburn, "Religiosity and Posttraumatic Stress in a Sample of East African
Refugees," Mental Health, Religion \& Culture 17, no. 2 (2014): 185-95.

36 Ibid., 31 .

37 Ibid., 29.

38 Ibid., 12. 


\title{
Forced Displacement and the Crisis of Citizenship in Africa's Great Lakes Region: Rethinking Refugee Protection and Durable Solutions
}

\author{
LUCY HOVIL AND ZACHARY A. LOMO
}

\section{Abstract}

This article explores refugee protection and durable solutions in Africa's Great Lakes region by examining conflict, displacement, and refugees in the light of the crisis of citizenship. Drawing on empirical data from nine studies across the region, we scrutinize the causes of conflict and displacement and refugee policies and practice in the region through the lens of citizenship. First, we argue that the continued plight of many refugees in the region without durable solutions results, at least in part, from an endemic and systemic inability of many people in the region to realize citizenship in a meaningful way. This inability, we argue, is a significant contributor to the continued forced displacement of millions of people, with many still refugees, even after living in the host states for over three decades. Second, we argue that solutions are failing because discussions about the root causes of refugee influxes and movements often fail to capture the intricately connected historical, political, social, economic, religious, and legal factors that engender displacement. We submit that full and equal enjoyment of the rights and benefits of citizenship by all, including access to citizenship for refugees, is one means of resolving displacement and providing durable solutions to refugees.

\section{Résumé}

Cet article s'engage à explorer la question de la protection des réfugiés et les solutions durables dans la région des
Grands Lacs en Afrique en étudiant le problème du conflit, du déplacement, et des réfugiés à la lumière de la crise de citoyenneté. En nous basant sur des données empiriques provenant de neuf études à travers la région, nous examinons de près les causes du conflit et du déplacement, ainsi que les politiques et les pratiques portant sur les réfugiés, en utilisant l'optique de la citoyenneté. Nous postulons deux arguments principaux: premièrement, que le sort tragique continu de nombreux réfugiés dans la région dépourvus de solutions durables provient, du moins en partie, d'une incapacité systémique et enracinée d'un nombre important de personnes dans les pays concernés d'actualiser la citoyenneté d'une manière significative; cette incapacité, nous avançons, contribue considérablement au déplacement forcé continu de plusieurs millions d'individus, avec de nombreuses personnes vivant toujours dans leurs pays d'accueil comme réfugiés même après plus de trois décennies. Deuxièmement, nous soutenons que l'échec des solutions vient du fait que souvent les discussions sur les causes profondes de l'influx et des déplacements des réfugiés ne prennent pas en compte l'enchevêtrement complexe de facteurs historiques, politiques, sociaux, économiques, religieux, et juridiques à plusieurs niveaux qui engendre le déplacement. Nous proposons qu'une pleine et égale jouissance des droits et avantages de la citoyenneté de la part de tous, y compris l'ouverture de l'accès à la citoyenneté pour les réfugiés, serait un moyen possible de résoudre le problème du déplacement, et d’offrir aux réfugiés des solutions durables.
(C) Author(s), 2015. This open-access work is licensed under a Creative Commons Attribution-NonCommercial 4.0 International license.
Cette oeuvre en libre accès fait l'object d'une licence Creative Commons Attribution-NonCommercial 4.0 International. 


\section{Introduction}

This article explores the intersection between citizenship and belonging and displacement and refugees in Africa's Great Lakes region. Africa's Great Lakes region, ${ }^{1}$ which witnessed genocide, displacement, and the massive production of refugees at the turn of the century leaves many questions unanswered. ${ }^{2}$ Why did the region implode? Why have thousands in the region remained refugees for over four decades with no solution in sight? And why have thousands more found a formal end to displacement only to be re-displaced? Without claiming to offer answers, this article seeks to widen debate 3 by analyzing forced displacement and the search for durable solutions to the plight of refugees through the lens of citizenship. While not denying the role played by other factors, the article's central thesis is that the continued plight of many refugees in the region without durable solutions results, at least in part, from an endemic and systemic inability of many people in the region to realize citizenship in a meaningful way. This inability, the article contends, is a significant contributor to the continued forced displacement of millions of people. Furthermore, just as the failure by many to realize the benefits of citizenship is one major cause of displacement, ensuring parity in the enjoyment of its benefits is also one means to resolve it.

\section{Theory and Method}

We do not situate our analyses in any particular theoretical approach to citizenship. ${ }^{4}$ We theorize citizenship as a status, legal or otherwise, that designates full membership in a state or community with concomitant rights or entitlements and duties, including the right and duty to challenge inequality in that state or community. This provides the starting point for our analysis. Citizenship differs from nationality. Nationality is a status acquired by birth in a given country. A person is a national of a given country by birth, while a person is a citizen of a given country either by birth or registration or naturalization. Nationality as used in international law is concerned with the "belonging of a person to a state,"5 or the legal bond between an individual and a sovereign state, which entitles that state to espouse claims on behalf of that national under international law. ${ }^{6}$ People may have multiple citizenships, although at international law a particular state's responsibilities or rights may take precedence in a particular encounter. The citizens of a given state may consist of a multiplicity of identities and nationalities that share a sense of belonging and common values and convictions associated with that state. Having full membership in a state or community brings with it benefits and costs, rights, and responsibilities.
However, while nationality is often the gateway to citizenship and therefore an important first step to ensure the legitimacy to belong, we argue that inclusion within a community or society needs to be about far more: inclusion has to take account of local and regional factors, in particular the arbitrariness and fluidity of colonial borders, increasing forced displacement, migration and mobility, and the ability of citizens to exercise citizenship rights and duties beyond the state of origin. Therefore, citizenship is also seen as a broader concept capable of absorbing new members beyond the nationality status of belonging to a group having the same culture, traditions, and history. While possessing citizenship as a legal status conferred by national citizenship law plays a crucial part, it does not automatically ensure access to and exercising rights as a citizen. Exclusionary tendencies continue to resist and deny membership to those considered "alien" or "foreign" to the locality defined by a particular nationality or ethnicity.

The research demonstrated how some groups and individuals negotiated their interests within the rigidly defined frameworks of belonging-as national citizens, ethnicities, or refugees-and found acceptance. These groups and individuals exercised what we describe as "empirical citizenship." Some were legally citizens but not indigenous to the locality, while others were refugees who legally were not citizens, and locally they did not belong there, and yet they found a way of being able to negotiate the social, economic, and political terrain in which they sojourned and found acceptance and exercised a level of mobility and participation in everyday citizenship activities beyond the national borders. We theorize "empirical citizenship" as a status of being accepted into a given community as a member, even if not originally from there, and being able to exercise citizenship rights such as social and economic rights and fulfil civic duties, including paying local taxes. The research demonstrates that "empirical citizenship" includes the ability to belong in the community in which people are living; and it often includes the realities of forms of belonging that cross borders. For refugees in particular, this involved some exercise of autonomy in making decisions about return, and those decisions often contradicted those of the officials who frame and determine when return is possible within a formal repatriation paradigm to be triggered by officialdom.

We observed that "empirical citizenship" challenges, within the context of the region, and Africa as a whole, a rigid notion of citizenship that is tied to the nation state. Refugees interviewed seem to opt for a form of flexible citizenship 7 that allows them to manoeuvre the treacherous terrain of survival in order to optimize their resources for the good of themselves and their families. From this perspective, we wondered whether citizenship, in its traditional
(C) Author(s), 2015. This open-access work is licensed under a Creative Commons Attribution-NonCommercial 4.0 International license.
Cette oeuvre en libre accès fait l'object d'une licence Creative Commons Attribution-NonCommercial 4.0 International. 
formulation, adequately interrogates the problems of belonging, identity, peace, and stability in the region. ${ }^{8}$

The main question throughout the research, therefore, was how citizenship and exclusion affect the creation of, experience of, and resolution to displacement. We theorized that the inability of many people in the region to realize citizenship in a meaningful way is a root cause of both conflict and displacement in the region and the ongoing failure to find solutions to exile.

To interrogate how citizenship and exclusion affect the resolution of displacement in the Great Lakes Region of Africa, we adopted a theoretical approach that allowed us to ground the inquiry within the social, economic, political, and legal contexts in which forced displacement and exclusion happens. Thus, a socio-legal, theoretical framework was adopted. It posits that any study, social or legal, should be grounded in its social, economic, political, and legal contexts and that analysis of any problem, legal or social, should be informed by data collected from the field. Qualitative methods of data collection were employed: open-ended questions were used in conducting one-on-one interviews with refugees, internally displaced persons, returnees, and civil society, and relevant officials in each of the seven countries where fieldwork was conducted; policy documents and articles on refugees, displacement, repatriation, and citizenship were also reviewed ${ }^{9}$

As with any empirical study, some caveats are in order. First, as we used qualitative methods of data collection, some limitations are unavoidable. For example, although we interviewed a wide range of people, our interviewees represent only a small sample of whole populations, and therefore any generalizations we make must be read in context. In addition, interviews took place in their natural settings, and our study may therefore not be replicated. ${ }^{10}$ Second, the quality of our data depends, to some extent, on our individual research skills and may be prone to personal world views.

These limitations notwithstanding, however, we believe collecting data using qualitative methods provided us, first, with a more useful way of exploring the complexity of social, economic, and political dynamics of displacement in the region. Second, it provided us a better understanding and descriptions of the personal experiences of the people we interviewed about displacement, exclusion, and citizenship in the region. Third, we were better able to grasp local situations, conditions, and stakeholder interests and needs than would, for example, quantitative approaches, such as asking respondents to complete a questionnaire with "yes" or "no" answers to complex set of problems.

\section{Causes of Conflict and Displacement in the Great Lakes Region}

With the exception of Tanzania, all the countries in the region have generated refugees and IDPs in large numbers since independence, and all have hosted refugees. Hundreds of thousands remain exiled outside or within their country with no solutions in sight. Numerous theories have been advanced to explain why endemic refugee flows and internal displacement have occurred in the region and Africa as a whole. Dominant in the literature is the extent to which the impact and legacy of colonialism is a cause of conflict and displacement. The history and evolution of "citizenship" in the region, intertwined with the history of the emergence of the modern African state, is a turbulent one, reflecting many of the wider issues dominating the post-colonial discourse. Notions of belonging were irrevocably changed with the advent of colonialism, which clearly defined the jurisdiction of the state, redefined the parameters of power, ${ }^{11}$ and regulated the movement of people. ${ }^{12}$

Mamdani, for instance, argues that crises in Africa are manifestations of the crisis of the post-colonial state. ${ }^{13}$ His central thesis is that the fault lines of current political instabilities and conflicts on the continent lie in the processes of the formation of the colonial state, which, he contends, resulted in a bifurcated state based on political identities of race and ethnicity. The colonial regime crafted "institutionally entrenched discrimination" into the colonial state by a plurality of laws-one for master and subject races and another set of legal regimes for ethnic groups. ${ }^{14}$

The creation by the colonial regime of a bifurcated state with institutionally embedded political identities, discrimination, and prejudices is certainly crucial to our understanding of the current political crises in the region. However, it does not fully explain why most post-independence leaders, who were presumably aware of the flaws of the colonial state and the risks it portended, chose to perpetuate aspects of a system fashioned to exploit resources and protect colonial interests, instead of carrying out reforms that could have addressed past inequalities and captured the diversity of nationalities that made up the mosaic of the new states.

The failure by post-independence leaders to build democratic states with viable institutions that not only allowed free entry and exit to political power but also provided effective checks and balances to the abuse of power, alongside inclusive citizenship policies and laws, is a key factor in understanding post-independence political instability and conflict in the region. Many post-independence leaders in the region, and Africa as a whole (possibly with the exception of Julius Kambarage Nyerere of Tanzania), lacked
(C) Author(s), 2015. This open-access work is licensed under a Creative Commons Attribution-NonCommercial 4.0 International license.
Cette oeuvre en libre accès fait l'object d'une licence Creative Commons Attribution-NonCommercial 4.0 International. 
a clear and encompassing vision for their new nations that sought to unite rather than divide; to build rather than destroy; to be inclusive rather than exclusive; and to be confident rather than insecure. ${ }^{15}$ Although there was much rhetoric about national unity by many African heads of state-such as post-independence leaders Jomo Kenyatta of Kenya, Idi Amin of Uganda, self-styled Emperor Bokasa of Central Africa, Mobutu Sese Seko of the former Zaire, and Robert Mugabe of Zimbabwe-in practice the domineering and coercive machinery of the colonial state was often replicated, with little tolerance for alternative views and dissent. Their politics and policies perpetuated inequalities and marginalization, in particular the polarization of citizens or communities along ethnic lines, which became a means of holding onto power.

Within this context, autochtone conceptions of belonging have thrived and become key determinants of citizenship. In autochthone understandings of citizenship the question of belonging is implicated by the question of who arrived and occupied a given territory first; and the question of who settled first is linked to the assertion of indigenousness of a particular group or society to the territory in question. ${ }^{16}$

Assertions or claims of indigenity in relation to a territory mean that other groups that are seen as immigrants or newcomers to the territory do not "belong": instead, they belong to their own "native" place to which they can return. In practice, however, this is not possible, given that many of the "newcomers," or "immigrants," or "settlers" have lived in the contested area for decades, if not centuries. And, as the research demonstrates, the turmoil and movement of people created by refugee flows in the region has intensified this debate.

In addition, the tendency by many commentators to attribute the causes of civil wars and political crises in Africa to cultural differences-and, in particular, to point to ethnicity as the scapegoat for most conflicts in Africais both flawed and misleading. It also risks imposing onto African realities solutions that not only treat the symptoms rather than the cause, but also assume that the causes of the problems are internal, thereby ignoring the role of external interests.

Therefore, in addition to the legacy of colonialism and the failure of the post-colonial state to address the inadequacies that it inherited, has been the inability of the postcolonial state to accommodate multiple forms of allegiance and belonging that would mitigate, rather than cause, conflict. Ekeh, in a 1975 seminal article, argues that there are two public realms in Africa that determine the "structure of modern post-colonial politics in Africa."17 One is based on "primordial groupings, ties, and sentiments," which "influence and determine the individual's public behaviour."18
This aspect of the public realm is ethnically based and driven by moral imperatives, similar to the function of the private realm in Western states. ${ }^{19}$ The other public realm "is historically associated with the colonial administration and ... has become identified with popular politics in postcolonial Africa." It is defined in terms of "military, civil service, the police, etc." Ekeh contends that this aspect of the public realm "has no moral linkages with the private realm" and calls it "the civic public." He concludes, "The civic public in Africa is amoral and lacks the generalised moral imperatives operative in the private realm and primordial public," and political actors in the post-colonial state operate simultaneously in both public realms, namely the civic and primordial publics. ${ }^{20}$ The dialectical relationship between these two realms, in Ekeh's view, explains the political crises afflicting some states in Africa, ${ }^{21}$ with clear implications for the realization of citizenship.

Thus, we argue that many of the causes of conflict and forced displacement, such as human rights violations, the struggle over control of political and economic power, ethnic conflict and civil war, are symptoms of deeper and interconnected problems. In particular, the failure by most postcolonial leaders to reform the colonial state and reorganize power by creating viable institutions that allow free entry and exit to political power and socio-economic opportunities and resources, and therefore the failure to address citizenship in a way that allows it to accommodate multiple identities lies at the root of recurrent political instability and conflicts in the region.

The question, however, is how to reconcile or reverse the logic of exclusion and avoid conflicts and civil war. Would drafting new national constitutions help to reconcile these competing issues and interests in ways that would allow those in exile to either have the option of taking new citizenship in their country of exile, or create the conditions of "acceptance" necessary to return to their former country of habitual residence? And would it allow those at "home" to feel a sense of belonging that secures their interests and those of their children, thereby diffusing future conflict? And, importantly for the purpose of this article, does refugee policy reflect the realities outlined above?

\section{Current Refugee Protection Policy Response and Practice}

Refugee law and policy, though well established, fail to resolve the problem of forced displacement both in addressing the root causes of violence, and ensuring an end to exile. The conventional policy instruments on refugees are crafted with a mindset that conceives refugees as a problem that imposes a burden on their hosts and calls for burden-sharing amongst states. The three "durable solutions"-repatriation,
(C) Author(s), 2015. This open-access work is licensed under a Creative Commons Attribution-NonCommercial 4.0 International license.
Cette oeuvre en libre accès fait l'object d'une licence Creative Commons Attribution-NonCommercial 4.0 International. 
local integration, and resettlement-reflect this problemcentric image of the refugee. The research focused primarily on the first two of these solutions, both of which are now discussed in turn.

\section{Repatriation and Citizenship}

Repatriation returns refugees to their country of origin or habitual residence. The 1951 Refugee Convention is silent on repatriation; ${ }^{22}$ it says nothing about its nature-voluntary or otherwise. Hathaway has argued that because the 1951 convention has not provided for voluntary repatriation, it is "wishful legal thinking to suggest that a voluntariness requirement can be superimposed on the text of the Refugee Convention." 23 The requirement of voluntariness is found only in the statute establishing the Office of the UNHCR, which requires the high commissioner to facilitate voluntary repatriation. ${ }^{24}$ In addition, the Executive Committee (ExCom) of the Office of the UNHCR has adopted conclusions emphasizing the voluntary character of repatriation. ${ }^{25}$ From a legal positivist perspective, the statute of the Office of the UNHCR and ExCom conclusions are not treaties and therefore not positive law. ${ }^{26}$

By contrast, the 1969 AU Convention explicitly states that repatriation should be voluntary. ${ }^{27}$ And while there is disagreement on whether there is any legal basis at international law for the voluntary character of repatriation, ${ }^{28}$ we submit that in the context of Africa, the legal basis for the international and voluntary character of repatriation is article 5 of the 1969 AU Convention, which emphasizes the voluntary character of repatriation.

Repatriation in the literature is often discussed in relation to "safe return" and the right of return. ${ }^{29}$ It is never discussed explicitly in the context of citizenship, with emphasis on the status of the person being a refugee. We treat repatriation as part of the exercise of the right of citizenship and not merely the desired solution to the refugee as a problem. Repatriation has typically been touted by national and international policy-makers as the best solution. This focus on repatriation not only has implications for the role that the other solutions (resettlement and integration) play in dealing with problems faced by refugees and finding permanent solutions, but also ignores the realities experienced by refugees, especially when return is coerced under the dubious concept of "safe return." 30 Increasingly, refugees have little choice in matters of repatriation. For instance, Rwandan refugees in Uganda, who were pressed to return to Rwanda, talked about their fear that return would not be voluntary, referring to previous repatriation experiences in which people have been forcibly repatriated. For some, it was the experience of being forced out of Tanzania in the late 1990s; for others it was coming under attack from the Rwandan army in the camps in eastern DRC; others had been forced out of Uganda in 2006. As one man said, "They told us that before the 31 July 2009, we had to return to Rwanda. People were afraid. We remembered Kabahinde and Kibati. And we remembered the forceful repatriation from Tanzania when a lot of people were hurt-some were decapitated and others were killed in road accidents." ${ }^{11}$ The current initiative was seen as a continuation of similar exercises: "I think this repatriation is forced. I remember what happened in Tanzania, Congo, Burundi. I remember what happened in Kibati in 2006. Those who want to go back, they can. You don't need a UNHCR convoy for that."32

New leadership in the countries of origin and the end of open conflict are often assumed to constitute an end to the circumstances that forced refugees into exile, and refugees are put under varying types of pressure to return, from the threat of withdrawal of assistance to actual withdrawal or forcible return. For example, in 2011 the government of Tanzania forced Burundian refugees through a new screening process and more rigorously enforced regulations forbidding them from travelling more than four kilometres outside the refugee camp. 33 When these measures proved ineffective in pressuring refugees to leave, cessation (withdrawal of refugee status) was formally invoked, and a forced return operation was undertaken.

A number of key findings on repatriation emerged from the research. The first focuses on the question of when repatriation is appropriate and how that can be determined. In exploring the views of Rwandan refugees living in Uganda in late 2009, at a time when the potential declaration of cessation was hanging over them, the research found that refugees were frightened about the prospect of returning to Rwanda, as indicated in the quotations above. The fears of the refugees highlighted the pitfalls in relying primarily on the absence of open conflict as a benchmark against which to promote return. Although many refugees will seek to return at the first sign of abating conflict, there will inevitably be huge variation within any group of refugees, and for many a lack of open conflict will not be enough. The assumption that all can return at once may lead to a lack of safety for those who are not ready to return voluntarily. Instead, the assessment of whether or not return is timely should be considered in terms of refugees' voluntary choices as citizens who can determine when it is risky for them flee and seek safety in exile, and when conditions are favourable for them to return home and they are able to renegotiate access to effective citizenship on return. Making this assessment will focus on political openness and factors such as good governance and effective systems of justice. It will also recognize variations within the refugee community: there may be situations in which the majority of refugees
(C) Author(s), 2015. This open-access work is licensed under a

Creative Commons Attribution-NonCommercial 4.0 International license.
Cette oeuvre en libre accès fait l'object d'une licence Creative Commons Attribution-NonCommercial 4.0 International. 
are able to recreate these bonds, but others are not able, as a result, for instance, of their political, ethnic, or religious profile. Consideration of these factors and a more individual approach to repatriation will more reliably predict when it is not only safe to return home, but when return will be a genuinely permanent solution.

Yet the findings showed that the governments of Rwanda and Uganda and the UNHCR in 2009 were ignoring these criteria. The government of Rwanda's arguments in favour of repatriation focused on the genocide and its immediate aftermath (particularly armed conflict up to 1998) as the main cause of exile. However, the findings showed that ongoing political repression in Rwanda was not only preventing many refugees from returning, it was generating new refugees: almost a quarter of all those interviewed had arrived in Uganda since 2001, indicating that the promotion of voluntary repatriation, much less invocation of the cessation clause, should be approached with caution.

The absence of armed conflict was also a key factor in motivating UNHCR and the government of Uganda to consider cessation (although at the level of the government of Uganda it is worth noting that it was never implemented). This approach failed to recognize that war and violence may profoundly reshape a polity and can create new threats to individuals who may continue to require protection as refugees. In fact, Rwandan refugees in Uganda described themselves as victims of a "war on individuals" by a repressive government, highlighting their desire to show the precariousness of their situation, but also its individualized nature.

Ultimately, successful repatriation genuinely reasserts the bond of citizenship between citizen and state, permitting the latter to protect the former and the former to engage in dialogue on the nature of the protection required. In this context, assessment of the appropriateness of return should focus on those elements that are most likely to determine the success of this renegotiation. Critical to this assessment are questions about governmental and societal discrimination, restrictions on freedom of movement, denial of property rights, access to justice, and exclusion from governance. Without the opportunity to re-establish the state and citizen bond and the realization of their full rights as citizens, therefore, refugees are likely to continue to resist return-and others who face similar exclusion will continue to flee. And critical to this assessment is the fact that it is the refugees themselves who will usually be in the best position to make the assessment of whether this bond can be re-established.

A second finding was the way in which citizenship provides a lens for negotiating how repatriation, when appropriate, takes place. Policy-makers and implementers often construct the repatriation of a refugee in a linear progression; it is typically understood as a single course of action in one direction: a refugee leaves exile, crosses a border, returns home, and reaches a basic level of reintegration. As they cross the border, refugees shed their refugee status, thereby becoming persons no longer of "concern" to the international community. Within this official process, repatriation looks like a primarily humanitarian enterprise. However, while this essentially humanitarian boxing of people and processes may be helpful inasmuch as refugees and returnees leverage the assistance it provides, the process is not only fundamentally at odds with the wider political and economic context and does not make sense of people's survival strategies, it also robs them of the autonomy to decide for themselves what is right. At worst, it undermines people's coping mechanisms: in trying to promote protection, narrow approaches to repatriation effectively limit or compromise it.

If viewed through the lens of citizenship, however, successful repatriation does not entail just stepping over a border: it is a long-term process of negotiated access to human rights protection and is strengthened by addressing threats to post-conflict recovery and reconstruction. It is highly complex and intimately connected with the political and economic context. From this perspective, the refugee is a citizen with autonomy to decide when and how to return home, which might involve several journeys between the country of exile and the home country and also establishing long-term relationships across the border long after the experiences of exile.

Our research with South Sudanese refugees in Uganda in 2010, in the midst of official repatriation, showed that refugees went to great lengths to take flexible approaches to repatriation. Some families spread themselves geographically, with a number of family members repatriating while others waited in Uganda, either to see whether stability would continue or to allow children to continue their education. Such coping strategies were found to have been crucial during South Sudan's escalating conflict. Taking a gradual approach was also seen as important, as it allowed some family members to rebuild and lay the groundwork for others to return.

This experience highlights the importance of flexible repatriation processes and, in particular, the importance of allowing refugees and returnees mobility in order to make the most appropriate decisions for themselves. To the extent that citizenship entails reforming links with communities, refugees and returnees need to be able to move within and between states as they renegotiate linkages and access to resources. As Long asserts, during repatriation and post-conflict reconstruction, "mobility offers a possible means to offset many of the weaknesses of physical return
(C) Author(s), 2015. This open-access work is licensed under a Creative Commons Attribution-NonCommercial 4.0 International license.
Cette oeuvre en libre accès fait l'object d'une licence Creative Commons Attribution-NonCommercial 4.0 International. 
programmes by providing access to alternative social, economic and cultural resources outside of the state of origin that may benefit refugees, their families and communities, and their home state." 34 From this perspective, repatriation policies should not undermine citizenship and the opportunities it offers to refugees when they choose to end their displacement.

Third, the findings demonstrated that the relationship between repatriation and citizenship may further be complicated by the local politics of belonging. While, at the national level, citizenship and belonging may be defined by citizenship legislation, at the local level citizenship may be defined differently. In some cases local structures may be more open. For example, self-settled (South) Sudanese refugees in Uganda paid local taxes in order to leverage greater acceptance at the local level.35 In other cases, it can be more restrictive, with local communities insisting on criteria of "indigenousness" as the basis of belonging. In this context, repatriation is caught between civic understandings of belonging, localized ethnic forms of belonging and citizenship, and notions of indigeneity, as illustrated by a group of Kinyarwanda-speaking (Tutsi) Congolese refugees living in a camp in Rwanda in 2011. The right of this group to belong is particularly contested, with many Congolese insisting that the refugees are actually Rwandan. The official repatriation process that was being considered included a mechanism by which returnees would be formally vetted by local authorities to determine whether or not they belonged in the areas to which they were to return. This mechanism, while essentially problematic, represents a unique formalization of processes that usually take place in informal and poorly documented ways. The process proposed was an interesting model but cannot be assessed, because in practice it was never deployed.

In the absence of an actual process, those who were considering a return to DRC recognized that in order for return to be viable, they would need to negotiate their legitimacy to belong nationally and locally. Refugees talked about the need to return as recognized Congolese citizens and not as Tutsis or Kinyarwanda speakers. They saw that their group identity had become a major source of instability and that the ability to genuinely (re)engage with the state as a citizen would be a key factor in determining the safety and durability of their return. However, they recognized that national acceptance had limited salience if they were not also accepted in the local areas from which they came, where they had land and property. The interaction between local and national belonging, therefore, was seen as a key factor in determining the ability to return and re-access livelihoods.

Fourth, the research demonstrated that land is a vital link between repatriation and citizenship: citizenship and belonging are intricately intertwined with land ownership; and land ownership is rooted in local belonging. These connections were illustrated by the research carried out with Burundian returnees from Tanzania in 2009, while Burundi was going through long and painful reconstruction after decades of violence, political turmoil, and displacement. In this context, the research showed that land was fundamental in creating an authentic reinstatement of the bond between citizen and state that had been violently broken: its equitable and just distribution was key to the reconstruction, reconciliation, and peace-building then taking place in Burundi.

The government of Burundi's policy of encouraging returnees to share "their" land with those they found living on it at the point of return (land that may have been wrongly appropriated, but on which many had been living for over three decades) was creating tension between returnees and those who had not fled. In these areas, the government of Burundi faced an unwinnable challenge with land claimants building strong legal cases and not enough land to go around. Solutions needed to focus on relieving pressure by creating alternative ways providing what the population was seeking through land-livelihoods and belonging. In this way, access to land could be addressed through a process that would rebuild civic trust and ensure the genuine reintegration of these former refugees.

Repatriation, therefore, when viewed through a citizenship lens, opens discussion on a broad range of dynamics and issues, all of which are critical to the creation of longterm stability. Ultimately, the way in which repatriation takes place can either destabilize a fragile situation or contribute to breaking cycles of violence and displacement. In the case of the latter, the genuine rebuilding of the bond of citizenship and belonging at both a national and local level are key.

\section{Local Integration and Citizenship}

Although article 34 of the 1951 convention stipulates that "contracting States shall as far as possible facilitate the assimilation and naturalisation of refugees," local integration through obtaining citizenship of host states has not been a priority in the Great Lakes region. The UNHCR defines local integration as including legal, economic, and social elements. The legal element is defined as "the establishment of a legal framework in which refugees gradually attain a wider range of rights in the host State-possibly, but not necessarily, leading to full citizenship and naturalisation."36 While recognition of the multiple elements of integration is positive, the fact that citizenship is not seen as a requirement is evidence of how hard it is to obtain in many parts of the world. It also raises questions about the durability of that integration without full citizenship.
(C) Author(s), 2015. This open-access work is licensed under a

Creative Commons Attribution-NonCommercial 4.0 International license.
Cette oeuvre en libre accès fait l'object d'une licence Creative Commons Attribution-NonCommercial 4.0 International. 
In the Great Lakes region, the prospects of refugees acquiring citizenship are limited. Citizenship is generally accessible by birth, registration, or naturalization, but in many cases, there are legal obstacles. In most of the Great Lakes region, citizenship by birth is accessible only on the basis of inheritance (jus sanguinis) and not on the basis of birth in the country (jus soli), so citizenship cannot be extended automatically to the children of refugees, even if several generations are born in exile. While this situation does leave open the possibility of accessing citizenship through either registration or naturalization, in practice this rarely happens. In Uganda, for instance, even after refugees have lived in the country for over three decades, their children and grandchildren born in Uganda are explicitly excluded from citizenship by registration. ${ }^{37}$ And while a person who has lived in Uganda for at least ten years can, in theory, apply for Ugandan citizenship by registration, he or she must have come to Uganda legally and voluntarily; ${ }^{38}$ this requirement automatically disqualifies refugees who came to Uganda involuntarily in response to war or fear of persecution in their countries more than thirty years ago. Refugees who have lived in Uganda for more than twenty years could explore the possibility to naturalize.39 The Uganda Citizenship and Immigration Control Act defines the criteria for acquisition of citizenship by naturalization and does not exclude refugees..$^{\circ}$ And crucially, the Refugee Act, 2006, also provides for refugees to acquire citizenship by registration, but only for "recognized" refugees. ${ }^{41}$

In most countries in the region it is theoretically possible for a refugee to naturalize, although there are many legal obstacles to doing so. In the DRC, for instance, naturalization requires approval by the National Assembly and the applicant must have performed "major services" to the country-criteria that few, let alone refugees, are likely to meet. In Rwanda, applicants for nationality must be free of "genocide ideology," a vague legal construct that has been used to persecute opponents. Other obstacles include requirements for very long periods of residency to apply for naturalization and filing fees that place the process out of reach of most refugees, even when they would otherwise qualify.

In other cases, political considerations become an obstacle, as was seen in the research from 2008 and 2013 on Burundi refugees who had been living in Tanzania since the 1970s. The government of Tanzania was offering citizenship to these refugees through naturalization, with the UNHCR covering the cost of filing, in order to ensure that refugees were able to access the process. Yet refugees were contesting the nature and quality of citizenship they had been offered. It came with a catch: to obtain their citizenship certificate, refugees were being asked to relocate to other areas of the country - a requirement with no justification under the law. They were being asked to leave their homes of the past three or four decades (a lifetime for most) and start again with people they did not know. The potential within national belonging, in this instance, was jeopardized by a rupture in local forms of belonging. Without their community structures around them, built through decades of exile, their coping mechanisms were going to be severely eroded and, for many, the inflexibility of the process undermined its potential.

Refugees were apprehensive about the extent to which citizenship on the basis of forced relocation would allow for full access to rights and, most crucially, the ability to secure their livelihoods. For the majority of those interviewed, therefore, the possibility of staying in Tanzania as legitimate citizens but retaining the potential to return to Burundi was the optimal outcome-and one that did seemed reasonable for a group of refugees who have spent almost four decades living in exile and uncertainty.

For the government and policy-makers, the ambivalence of refugees who were refusing the unique opportunity to gain Tanzanian citizenship on the basis of having to move from the settlement, or who were talking about the possibility of returning to Burundi in the future, was seen as unacceptable and difficult to understand. Policy-makers premise Tanzanian citizenship as both a permanent and exclusive national identity, and a "solution" that should end concerns about the availability of protection. From the perspective of the refugees, however, there was little evidence that either would be a panacea, fully addressing all rights, security, and livelihoods issues.

Although the issue has recently been resolved, inasmuch as the government of Tanzania is no longer making citizenship contingent upon relocation, the discussion that led to this decision reveals the tension between the refugees' understanding of citizenship and that of the Tanzanian authorities, and raises fundamental policy questions about the nature of citizenship in the context of a multiplicity of identities and ties. In particular, it demonstrates that while policy-makers generally see naturalization as the end point of integration, refugees see it as distinct from their "empirical citizenship," which is just beginning to be established and is influenced by, but distinct from, the offer of national citizenship.

One issue that came through as critically important in establishing empirical citizenship was the need for freedom of movement and residence. Not only are such freedoms critical in allowing refugees to seek out the place or places where they have greatest possibility to ensure their local belonging, it is also a gateway to other rights. For instance, refugees who are able to move freely are more likely to be able
(C) Author(s), 2015. This open-access work is licensed under a Creative Commons Attribution-NonCommercial 4.0 International license.
Cette oeuvre en libre accès fait l'object d'une licence Creative Commons Attribution-NonCommercial 4.0 International. 
to access livelihoods. These principles are well reinforced by international law.

\section{Rethinking Durable Solutions in the Context of Citizenship}

Two main conclusions are drawn from this review of underlying causes of conflict-induced displacement in the Great Lakes and the status quo on policy instruments on durable solutions to the plight of refugees in the region and the role that citizenship could play in providing such a solution. First, post-independence leaders failed to reform the colonial state and reorganize political power to address discrimination, inequality, and politicized identities that were legally embedded within the colonial state. As a result, the default position-at least at a political level-appears to be the exclusion of those considered outsiders, rather than to make efforts to encourage their integration. A key consequence is failure to adopt citizenship policies and criteria that are inclusive, and that, in turn, explains why hundreds of thousands of refugees, despite living in exile for decades, are still unable to access citizenship. And even in exceptional cases such as Tanzania where refugees were offered citizenship-either as a result of pan-Africanist idealism or as a solution to ending refugee status and integrating them into Tanzanian society-it has been construed in inflexible terms, giving refugees limited space to organize their lives as citizens with multiple identities and sense of belonging.

Second, the way in which refugee policies have been implemented has paid inadequate attention to the dynamics of inclusion and exclusion that are a common feature in any context, not least where resources are limited. Instead of refugees being seen as an asset, their presence has consistently been constructed as a threat, ensuring that their status as outsiders is embedded in the humanitarian response (as opposed to a political response) to refugees.

Problems in both citizenship policy and the way in which the refugee regime is constructed and implemented within this context, conspire to reinforce these problems rather than resolve them, creating the cycles of violence and conflict that we continue to see in the Great Lakes. Instead, policies have exacerbated the trend of exclusion by isolating refugees in camps, restricting their movement, and offering limited resettlement places. This isolationist approach is reminiscent of the way in which colonial and post-independence rulers excluded "outsider" communities from the benefits of citizenship and established a patronage system that allowed those in power to manipulate and control political power to their advantage. Refugee policies have continued to see refugees as outsiders, as being not ethnically and/or historically connected to the countries in which they have sought refuge.
Indeed, the status of refugees as outsiders has been exacerbated by the humanitarian response to refugee issues. This bedrock of exclusion has had two negative consequences for refugees and their host communities. First, refugees, as objects of charity, are treated as passive victims who must be cared for and maintained by an elaborate international bureaucracy assisted by local actors. ${ }^{42}$ Second, many refugee groups have lived for decades without solutions to their plight, unable to integrate into the community. These "protracted refugee situations" have been blamed on the conditions in their country of origin rather than the inability for the host state and other interests to allow their inclusion. 43 As a result, for decades refugee policies in the region and Africa as a whole have not only failed to provide the majority of refugees with solutions to their plight or address their aspirations, but have failed to benefit host communities in a meaningful way. As a result, refugee policy has failed for the same reasons that citizenship policies and laws in postindependence Africa have failed to avert the political crises that engulfed the region and Africa as a whole.

\section{A New Approach to Refugee Policy}

The way forward, we suggest, is a realignment of refugee policies in the region in a way that makes them inclusive, focusing on the dignity and resourcefulness of refugees. Refugee policies need to view refugees as citizens and rational actors, notwithstanding their displacement, who are best placed, either as individuals or in communion with others, to determine what their interests are and how to protect them. This would translate into a policy that promotes an organic interaction between refugees and host communities that starts at the onset of a refugee influx and allows both to mutually benefit from each other; that identifies potential areas of tension and encourages collaboration between both communities to identify ways of removing the cause of that tension; and that allows local actors to benefit from the economic and business opportunities that result from the presence of the refugees and thereby minimizes xenophobia.

Ultimately, however, both refugee and citizenship law and policy need to be realigned: refugee policy, as with citizenship policy, needs to shed its emphasis on fear, exclusion, manipulation, ethnicity, and historical ties to territory, and instead be rooted in values such as community, protection of strangers, equality, fairness, and justice that transcend the current preoccupation with refugees as a problem. Indeed, on the basis of these values, refugee hosting communities are often the first "humanitarian actors" to protect refugees: progressive refugee policy could tap into this goodwill instead of undermining it.

In addition to community value systems, international law, its weaknesses and inherent biases notwithstanding, 44
(C) Author(s), 2015. This open-access work is licensed under a Creative Commons Attribution-NonCommercial 4.0 International license.
Cette oeuvre en libre accès fait l'object d'une licence Creative Commons Attribution-NonCommercial 4.0 International. 
in particular human rights law could provide some basis for realigning refugee policy. Article 26 of the 1951 convention, for example, stipulates that "each Contracting State shall accord refugees lawfully in its territory the right to choose the place of their residence and to move freely within its territory." This right is subject only to "any regulations applicable to aliens generally in the same circumstances." A general limitation to this right might be article 9 of the convention, which allows a contracting state, "in time of war or other grave and exceptional circumstances" to take "provisionally measures which it considers to be essential to the national security." But this provision does not give contracting states a free ride; it must relate to a particular refugee, "pending a determination by the Contracting State that the person is in fact a refugee and that continuance of such measure is in the interest of national security." Thus, refugee policy premised on the right to freedom of movement and choice of residence will give refugees agency and allow them to integrate in the communities in ways that benefit them and their host communities.

Related to the right to freedom of movement and choice of residence as a key aspect of a progressive refugee policy is the non-discrimination obligation imposed on states by some international human rights instruments. As stated above, current refugee policy is premised on a care and maintenance paradigm that requires refugees to be encamped with most of their rights restricted. Encampment on the basis of refugee status is a form of discrimination and offends the provisions of most international human rights instruments. Article 2 of the African Charter on Human and Peoples Rights, for example, stipulates, "Every individual shall be entitled to the enjoyment of the rights and freedoms recognized and guaranteed in the present Charter without distinction of any kind such as race, ethnic group, colour, sex, language, religion, political or any other opinion, national and social origin, fortune, birth or other status." Article 2 (1) of the International Covenant on Civil and Political Rights (ICCPR) categorically enjoins contracting states to "ensure to all individuals within its territory and subject to its jurisdiction the rights recognized in the present Covenant, without distinction of any kind, such race, colour, sex, language, religion, political or other opinion, national or social origin, property, birth or other status."

Thus, refugee and citizenship policies have much in common and can be reformed by adopting inclusive criteria already in existence within the repository of community value systems or international law and international human rights instruments.

\section{Conclusion}

The problem of conflict, displacement, and refugees in the region is, to a large extent, intertwined with the crisis of citizenship. There are theories advanced to explain the causes of the problem, including ethnicity, the legacy of colonial rule, the failure to reform the colonial state by post-colonial leaders, violations of human rights, and the logic of "sovereignty and state." While all these ideas shed some light on the causes of the problem, at the core of these factors is the logic of inclusion and exclusion. Seen from this perspective, the dialectic between civic public and primordial public, or civic citizenship and ethnic citizenship, or the logic of sovereignty and state, are simply manifestations of a predisposition to include or exclude others-a phenomenon that is by no means unique to Africa.

Access to and control of finite resources such as land and the mineral wealth in the region drive exclusion or inclusion. In particular, ethnicity and historical ties to territory are commonly used to either legitimatize an indigenous group's or de-legitimatize the newcomer's claim to access and control over these resources. This struggle for access to and control of these resources has forced ethnic identities to take on hardened and aggressive boundaries, which has inevitably resulted in conflict and its attendant ramifications.

The presence of refugees intersects with many of these dynamics. Yet policy instruments fail to address these issues, in particular through the ongoing emphasis on repatriation and encampment of refugees that ignores the relationship between return and the versatility of citizenship. Inextricably linked to this lack of success is the fact that de jure local integration is not considered a solution for refugees, even those who have lived in exile for extended periods of time, many for generations: most states in the region restrict access to their citizenship for refugees. The international processes initiated for the region, such as the International Conference on the Great Lakes Region, while resulting in broad policy instruments that addressed discrimination, racism, ethnicism, exclusion, and national unity, never tackled citizenship as an explicit problem and its connections with racism, ethnicism, exclusion, and national unity.

Current approaches to refugee protection and embedded structures are profoundly harmful in their outcome and continue to fail to adequately provide solutions to their plight. A radical reform of governance structures-locally, regionally, nationally, and internationally_that repeatedly fail the citizenry they claim to represent is urgently needed.
(C) Author(s), 2015. This open-access work is licensed under a Creative Commons Attribution-NonCommercial 4.0 International license.
Cette oeuvre en libre accès fait l'object d'une licence Creative Commons Attribution-NonCommercial 4.0 International. 
Lucy Hovil is the senior researcher at the International Refugee Rights Initiative, where she has co-ordinated a research project on the linkages between citizenship, displacement, and conflict for the past seven years. She is also managing editor of the International Journal of Transitional Justice. She founded and ran the Research and Advocacy Department of the Refugee Law Project (Faculty of Law, Makerere University, Kampala) for eight years. The author may be contacted atlucy@hovil.co.uk.

Zachary A. Lomo is a graduate of Harvard Law School, Makerere University, and Law Development Centre, and is acting dean of School of Law, St. Augustine International University, Kampala, Uganda and a CIGI research student at Osgoode Hall Law School, York University. He is former director, Refugee Law Project (School of Law, Makerere University), 20012006. The author may be contacted at zac.lomo@gmail.com.

\section{Notes}

1 The region consists of the territory covering twelve states that are members of the International Conference on the Great Lakes Region (ICGLR): Angola, Burundi, Central African Republic, Republic of Congo, Democratic Republic of Congo, Kenya, Uganda, Rwanda, Sudan, South Sudan, Tanzania, and Zambia.

2 This is even after a whole international conference, the International Conference on the Great Lakes Region (ICGLR), was jointly called and institutionalized by the United Nations and the African Union to seek answers and permanent solutions. On the ICGLR, see its official website at http://www.icglr.org/index.php/en/. For a comparative analysis of the ICGLR, see, e.g., Charlotte Heyl, "The International Conference on the Great Lakes Region (ICGLR): An African CSCE?," Konrad Adenauer Stiftung International Reports 12 (2010): 87-105. On the work of the ICGLR Secretariat, see, e.g., Morten Boas, Randi Lotsberg, and Jean-Nuc Ndizeye, "The International Conference on the Great Lakes Region (ICGLR): Review of Norwegian Support to the ICGLR Secretariat" (2009), http:// www.norad.no/om-bistand/publikasjon/2009/the-international-conference-on-the-great-lakes-region-icglr--review-of-norwegian-support-to-the-icglr-secretariat/.

3 While there are numerous studies on forced displacement and the crises engulfing the region, fewer approach it explicitly from a citizenship perspective; see, e.g., World Bank, Forced Displacement in the Great Lakes Region: A Development Approach (Washington DC: World Bank, 2015); Tom Ogwang, "Armed Conflict and Forced Migration in the Great Lakes Region of Africa: Causes and Consequences," International Journal of Research in Social Sciences 4, no. 2 (2014): 147-61; Won Kidane, "Managing Forced Displacement by Law in Africa: The Role of the
New African Union IDPs Convention," Vanderbilt Journal of Transnational Law 44, no. 1 (2011): 1-85; Chris Huggins, Herman Mushara, Prisca Mbura Kamungi, Johnstone Summit Oketch, and Koen Vlassenroot, "Conflict in the Great Lakes Region: How Is It Linked with Land and Migration?," Natural Resource Perspectives 96 (2005): 1-4; Bonaventure Rutinwa, "Forced Displacement and Refugee Rights in the Great Lakes Region," African Journal of International Affairs 1, no. 2 (1998): 11-43. Our study flows from the first "Citizenship and Forced Migration in the Great Lakes Region" consultative meeting on co-organized by the Social Sciences Research Council and the International Refugee Rights Initiative, Kampala, Uganda, 2005.

4 A detailed discussion of the major theoretical approaches to citizenship is beyond the scope of this article. Generally, see, e.g., Thomas Humphrey Marshall, Citizenship and Social Class (Cambridge: Cambridge University Press, 1950); Michael Mann, "Ruling Class Strategies and Citizenship," Sociology 21, no. 3 (1987): 339-54; Bryan S. Turner, "Outline of a Theory of Citizenship," Sociology 24 , no. 2 (1990): 189-217. For a collection of essays by leading theorists on citizenship, see, e.g., Ronald S. Beiner, ed., Theorizing Citizenship (Albany: State University of New York Press, 1994). For an economics approach to citizenship, see, e.g., Graziella Bertocchi and Chiara Strozzi, "The Evolution of Citizenship: Economic and Institutional Determinants," Journal of Law and Economics 53, no. 1 (2010): 95-136.

5 See, e.g., The Hague Convention on Certain Questions Relating to the Conflict of Nationality Laws, 12 April 1930 in 179 LNTS 89 and 24 AJIL (Supplement) (1930).

6 See, e.g., Nottebohm Case (Second Phase), Judgment of April 6th, 1955: ICJ Reports, p. 4; for a discussion of this case, see, e.g., Joseph L. Kunz, "The Nottebohm Judgment (Second Phase)," American Journal of International Law 54 (1960): 536-71.

7 See, e.g., Aihwa Ong, Flexible Citizenship: The Cultural Logics of Transnationality, 2nd ed. (Durham, NC: Duke University Press, 1999).

8 See, e.g., Saskia Sassen, Territory, Authority, Rights: From Medieval to Global Assemblages, 2nd ed. (Princeton, NJ: Princeton University Press, 2008).

9 Instead of having separate sections present and discuss the findings, we decided to present them in a thematic way, allowing the voices of the people we interviewed to speak to the issues addressed in this article.

10 See, e.g., W. Wiersma, Research Methods in Education: An Introduction (Boston: Allyn \& Bacon, 200o).

11 A. Kraler, "The State and Population Mobility in the Great Lakes," Working Paper no. 4, Sussex Migration (2004): 10. 12 J. Herbst, States and Power in Africa: Comparative Lesson in Authority and Control (Princeton, NJ: Princeton University Press, 2000), 227.
(C) Author(s), 2015. This open-access work is licensed under a Creative Commons Attribution-NonCommercial 4.0 International license.
Cette oeuvre en libre accès fait l'object d'une licence Creative Commons Attribution-NonCommercial 4.0 International. 
13 M. Mamdani, When Victims Become Killers: Colonialism, Nativism, and the Genocide in Rwanda (Princeton, NJ: Princeton University Press, 2001).

14 Ibid., 29.

15 See Zachary A. Lomo, "Regional or National Protection for Great Lakes IDps?," special issue, Forced Migration Review (December 2006): 25.

16 S. Jackson, "Sons of Which Soil? The Language and Politics of Autochthony in Eastern D.R. Congo," African Studies Review 49, no. 2 (2006): 95-123.

17 P.P. Ekeh, "Colonialism and the Two Publics in Africa: A Theoretical Statement," Journal of Comparative Studies in Society and History 17, no. 1 (1975): 92, 106.

18 Ibid., 92.

19 Ibid.

20 Ibid., 92, 93. Emphasis in the original.

21 Ibid., 93.

22 But article 33 of the convention prohibits the forcible expulsion or return (non-refoulement) of refugees to frontiers of territories where their rights and freedoms will be violated, see, 1951 Refugee Convention, 189 UnTs 137, 176.

23 James C. Hathaway, "The Meaning of Repatriation," International Journal of Refugee Law 9, no. 4 (1997): 551. Also see same arguments in Hathaway, The Rights of Refugees under International Law (Cambridge: Cambridge University Press, 2005), 917-53. For a criticism of this perspective, see, e.g., B.S. Chimni, "From Resettlement to Involuntary Repatriation: Towards a Critical History of Durable Solutions to Refugee Problems," Refugee Survey Quarterly 23, no. 3 (2004): 61.

24 See article 1, Statute of Office of the United Nations High Commissioner for Refugees.

25 See, e.g., Ехсом Conclusion No. 18 (1980); Excom Conclusion 40 (1985); and ЕХсом Conclusion No. 101 (2004): Legal Issues in the context of voluntary repatriation of refugees.

26 See, Hathaway, Rights of Refugees, 917-20.

27 See article 5 (1) of the 1969 OAU Convention Governing Specific Aspects of Refugee Problems in Africa.

28 See, e.g., Hathaway, "Meaning of Repatriation"; Guy S. Goodwin-Gill, "Voluntary Repatriation: Legal and Policy Issues," in Refugees in International Relations, ed. Gil Loescher and L. Monahan (Oxford: Oxford University Press, 1989), 255; Guy S. Goodwin-Gill and Jane McAdam, The Refugee in International Law, 3rd ed. (Oxford: Oxford University Press, 2007), 492-7; Chimni, "From Resettlement to Voluntary Repatriation."

29 See, e.g., UNHCR, "Discussion Note on Protection Aspects of Voluntary Repatriation," 1 April 1992, EC/1992/sCP/CRP.3; also see, e.g., UNHCR, Handbook on Voluntary Repatriation: International Protection (Geneva: UNHCR, 1996).

30 See, e.g., Chimni, "From Resettlement to Voluntary Repatriation," 60-3.
31 Interview with refugee man, Nakivale refugee settlement, Uganda, 17 November 2009.

32 Interview with refugee man, Nakivale refugee settlement, Uganda, 18 November 2009.

33 International Refugee Rights Initiative and Rema Ministries, "An Urgent Briefing on the Situation of Burundian Refugees in Mtabila Camp in Tanzania," 10 August 2012, http://www.refugee-rights.org/Assets/PDFs/2012/ Mtabila\%2OFInAL.pdf.

34 Katy Long, "Home Alone? A Review of the Relationship between Repatriation, Mobility and Durable Solutions for Refugees," UNHCR Evaluation and Policy Development Services (2010). See also Oliver Bakewell, "Repatriation and Self-Settled Refugees in Zambia: Bringing Solutions to the Wrong Problems," Journal of Refugee Studies 13, no. 4 (2000): 356-73; and Lucy Hovil and Moses Chrispus Okello, "The Right to Freedom of Movement for Refugees in Uganda," in Refugee Rights: Ethics, Advocacy and Africa, ed. David Hollenbach (Washington DC: Georgetown University Press, 2008).

35 Lucy Hovil, "Self-Settled Refugees in Uganda: An Alternative Approach to Displacement?" Journal of Refugee Studies 20 (2007): 599-620.

36 UNHCR, "The Benefits of Belonging: Local Integration ptions and Opportunities for Host Countries, Communities and Refugees," http://www.unhcr.org/4e3276e26.html.

37 See article 12(1)(a)(ii), Constitution of Uganda.

38 See article 12(2)(b), Constitution of Uganda.

39 See article 13, Constitution of Uganda.

40 See section 16(5), Uganda Citizenship and Immigration Control Act, 1997 as amended.

41 See section 45 of the Refugee Act, 2006.

42 On this aspect, see, e.g., Michel Agier, Managing the Undesirables: Refugee Camps and Humanitarian Government (Cambridge: Polity, 2011), 199-210; Guglielmo Verdirame and Barbara Harrell-Bond, Rights in Exile: JanusFaced Humanitarianism (New York: Berghahn Books, 2005), 271-325.

43 See, e.g., Nathaniel H. Goetz, "Lessons from Protracted Refugee Situations," Working Paper No. 74, Centre for Comparative Immigration Studies, University of California, San Diego, April 2003; Executive Committee of the High Commissioner's Programme, "Protracted Refugee Situations," UN Doc No. EC/54/sC.CRP.14, 10 June 2004, para. 15.

44 See, e.g., Antony Anghie, Imperialism, Sovereignty, and the Making of International Law (Cambridge: Cambridge University Press, 2005); Jack L. Goldsmith and Eric A. Posner, The Limits of International Law (Oxford: Oxford University Press, 2007).
(C) Author(s), 2015. This open-access work is licensed under a Creative Commons Attribution-NonCommercial 4.0 International license.
Cette oeuvre en libre accès fait l'object d'une licence Creative Commons Attribution-NonCommercial 4.0 International. 


\title{
Fear and (In)Security: The Canadian Government's Response to the Chilean Refugees
}

\author{
SUHA DIAB
}

\begin{abstract}
This article examines Canada's response to the Chilean refugee crisis in 1973. It explores the conditions that made the resettlement of Chilean refugees possible, despite the reluctance of the Canadian government to provide protection for them. The article focuses on the relation between the Canadian government's regulatory discourses and practices on the one hand, and the Canadian public's contestation of, and challenges to, such discourses and practices on the other.

The Chilean refugee crisis revealed that the Canadian refugee protection regime was subject to political ideology, with very little consideration given to the suffering of refugees constructed as a threat to Canadian social, political, and economic well-being. However, civil society played a pivotal role in compelling the government to take a stance toward the refugees, though the government was able to control refugee reception by being deliberately selective about which lives it would save. The visibility and the success of the Canadian public in advocating on behalf of the Chilean refugees demonstrated the potential of this emerging civil power to affect refugee policies and practices while also revealing its limitations.
\end{abstract}

\section{Résumé}

Cet article examine la réponse du Canada à la crise des réfugiés chiliens de 1973. Il explore les conditions sous lesquelles la réinstallation des réfugiés chiliens était rendue possible malgré la réticence de la part du gouvernement canadien à offrir une protection pour ces réfugiés. L'article se concentre en particulier sur le lien entre les discours et pratiques règlementaires du gouvernement canadien d'un côté, et de l'autre la contestation ainsi que l'opposition envers ces discours et pratiques de la part de la société civile canadienne.

La crise des réfugiés chiliens avait démontré que le système canadien de protection des réfugiés était sous l'emprise de l'idéologie politique, donnant très peu de considération à la souffrance humaine des réfugiés, qui étaient présentés comme une menace au bien-être social, politique et économique du Canada. Néanmoins, la société civile avait joué un rôle déterminant en incitant le gouvernement à adopter une position envers les réfugiés, bien que celui-ci avait pu maintenir son emprise sur l'accueil des réfugiés en sélectionnant d'une façon délibérée lesquels il voulait sauver. La visibilité ainsi que le succès de la société civile canadienne dans son intervention en faveur des réfugiés chiliens avait mis en évidence le potentiel de cette force civile émergente, mais en même temps avait aussi souligné ses limitations.

\section{Introduction and Review of the Literature}

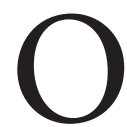
n 11 September 1973, General Augusto Pinochet, supported by the American administration and the Central Intelligence Agency (CIA), led a successful coup d'état against the democratically elected communist government of Salvador Allende in Chile. The first few months following the coup were the most critical, because Pinochet's military and security forces used the
(C) Author(s), 2015. This open-access work is licensed under a Creative Commons Attribution-NonCommercial 4.0 International license.
Cette oeuvre en libre accès fait l'object d'une licence Creative Commons Attribution-NonCommercial 4.0 International. 
most lethal forms of violence in order to eliminate "the cancerous tumor" of opposition. ${ }^{1}$ Thousands were killed or tortured by virtue of their political affiliation with Allende.

With Amnesty International's revelation of these atrocities to the international community in late 1973, Pinochet's governing style was put under scrutiny, leading him to adopt a more calculated and controlled display of violence. While there is no credible figure on the number of civilians killed during this period, Amnesty International estimated that between 11 September and the end of December 1973, 5,000 to 30,000 people lost their lives in detention centres, or were simply killed in the open streets.

Chileans and other nationals whose lives were in immediate danger sought sanctuary in foreign embassies in Santiago, since they were considered safer than the camps established by the United Nations High Commissioner for Refugees (UNHCR). ${ }^{2}$ Unlike the many embassies in Santiago that granted diplomatic asylum to refugees, the Canadian embassy was very selective and reluctant to allow people in. This response reflected the Canadian government's general attitude toward the Chilean refugees, which was characterized by apprehension and suspicion.

With the exception of providing protection to fifty young and educated individuals in its embassy, the Canadian government avoided any meaningful action to save the lives of people in danger in the first four months following the coup. The unique treatment of Chilean refugees brings to the fore the contradictions inherent in Canada's perceived humanitarian tradition of refugee protection, especially considering the swift Canadian response to the Ugandan-Asian refugee crisis the year before. In less than three months after the expulsion order imposed by Amin in August 1972, the Canadian government resettled more than 6,00o Asians.

Studies have examined the Canadian response to the Chilean refugees. For instance, Dirks (1979), Troper (1993), and Whitaker (1987) contend that anti-communist ideology (informed by Canada's economic interests) was the driving force behind the delays and rejections of many of the applications submitted by Chileans for resettlement. ${ }^{3}$ Duggan (1994), Knowles (2007), and Simmons (1993) assert that the government's decision to intervene in the Chilean crisis was due to a defiant public that challenged the resettlement scheme. ${ }^{4}$ These studies provide useful information on the factors influencing the Canadian government's approach in Chile. However, historical accounts tend to over-simplify the complexity of this response, or provide very little insight into how government policies and practices were implemented to achieve its goal in limiting the number of Chileans entering Canada.

The only work written in English that pays close attention to, and offers a comprehensive examination of, the response of the Canadian government in Chile is Francis Peddie's Young, Well-Educated, and Adaptable, published late last year. Peddie presents a more complex and multilayered analysis of Canada's response. ${ }^{5}$ He points to the multiple forces at work that influenced it, including Canada's economic and national interests, relations with the United States, the Canadian ambassador's attitudes toward Allende and Pinochet, and the instrumental role played by Canadian civil society, especially church groups. Ultimately, Peddie asserts that the reaction of the Canadian government was "shaped [more] by ideological concerns and economic prerogatives," and less by ostensible humanitarian concerns. ${ }^{6}$

Peddie presents a full account of the different forces that affected the Canadian government's response, and thus provides a pivotal contribution to this area of study. Unfortunately, he provides very little analysis of how these different forces came together to control the entry of Chilean refugees to Canada. This deficiency might be due to the fact that his study, as he points out, is less concerned with "state actors and structural factors" than with how Chileans dealt with "the issues of admission and settlement."7 Peddie also places too much emphasis on Canada's relation with the United States as a determining factor of its response.

My research, which involved reading thousands of documents and exchanges between government officials, has found very little evidence to support this claim. Canadian government officials formulated and rationalized their response to the refugee crisis in Chile on many occasions, but relations between Canada and the United States did not appear to play any significant role. Similarly, Canada's decision to recognize the junta, which arguably had farreaching implications, paid very little attention to CanadaU.S. relations. Once the safety of Canadians in Chile was established, the decision to recognize the junta was based mainly on Canada's economic interests, while taking into account decisions made by other countries, especially in the Commonwealth and Latin America. This was clearly demonstrated in a memorandum to the minister of external affairs and the prime minister in late September 1973:

Re-establishing de jure diplomatic relations with Chile would evidently prove most helpful in negotiating, probably multilaterally and at the higher official level, a solution to this pressing matter. From a commercial point of view, recognition is becoming an urgent requirement. Before the coup, the EDC had insured the sale of six Twin Otters to the Chilean national airline LAN. These airplanes are now being assembled and a contract is to be signed with LAN. ITAC has informed us that the Chileans badly need these airplanes and will arrange for the signature of the contract immediately following the recognition ... Further withholding recognition ... could well start complicating our bilateral
(C) Author(s), 2015. This open-access work is licensed under a Creative Commons Attribution-NonCommercial 4.0 International license.
Cette oeuvre en libre accès fait l'object d'une licence Creative Commons Attribution-NonCommercial 4.0 International. 
relations. The two basic conditions for extending recognition have been fulfilled: as already mentioned the Junta firmly controls the national territory and it has pledged that it will honour Chile's international obligations which includes the debt to the members of the Paris Club. The military can also claim that their regime is enjoying reasonable support from large, moderate sectors of the population as the only alternative to chaos. Up to this date some 35 countries have recognized the Junta. ${ }^{8}$

The absence of any American influence is not surprising. Unlike his predecessors, Trudeau believed that Canada needed to focus less on pursuing ideological alliances with the United States, and more on developing its international economic interests. 9 This move coincided with the relative decline of U.S. hegemony in some parts of the world, as well as Trudeau's uneasy relationship with the U.S. administration during Nixon's term in office. ${ }^{10}$ Between 1968 and 1976, Canada showed leadership and independence on the world stage by seeking closer economic ties with countries in the Commonwealth, Asia, Africa, Europe, Latin America, and the Caribbean, including communist countries, while distancing itself from the United States and its ideological policies.

Focusing on the first four months of the crisis, the study is concerned both with the forces and relations of power that made it possible for the Canadian government to intervene and resettle Chileans, and with how these forces and relations were applied and assembled through legislation, policies, institutions, discourses, and other practices to create certain effects.

The first part discusses my theoretical and methodological approach, which relies on the work of Michel Foucault, Gilles Deleuze, and Félix Guattari on assemblage/ apparatus, as well as on Tania Li's analysis of practices of assemblage. The second part applies the practices proposed by Li to examine how the Canadian government assembled its response to the Chilean refugee crisis. The article concludes with a summary of its main contributions and potential future work in the area.

The article argues that "cultural racism," along with coveted trade agreements and the desire to halt communist and Quebec separatist contamination-in short, Canada's political and economic interests-initially overshadowed the human suffering inflicted by the Pinochet regime. Cultural racism, as Balibar points out, is employed to exclude cultures that do not possess Western liberal values, such as “individual' enterprise, social and political individualism."11

In a context of growing public protests, the Canadian government had to seriously commit to an action plan for resettlement. It justified this intervention on the grounds of security and humanitarian concerns. As a result of the screening processes of the Royal Canadian Mounted Police
(RCMP), which sought to exclude individuals with communist or Quebec separatist leanings, and health and immigration officials who implemented Canada's point system, a well-educated, young, and highly desirable immigrant group of Chileans was selected. ${ }^{12}$ That being said, Canada's assembled response was not straightforward, as it reflected contradictions and tensions between the stakeholders involved.

\section{Theoretical Perspective and Methodology}

In his influential Confession of the Flesh, Foucault elaborates on the concept of dispositive/apparatus, noting that it refers to the system of relations (of power) established between "a thoroughly heterogeneous ensemble consisting of discourses, institutions, architectural forms, regulatory decisions, laws, administrative measures, scientific statements, philosophical, moral and philanthropic propositions-in short, the said as much as the unsaid. Such are the elements of the Apparatus." ${ }^{13}$ Through these complex relations of power (whether repressive and negative, or positive and productive), the apparatus shapes conduct.

Foucault adds that the apparatus involves different connections and reconfigurations between heterogeneous elements. "[A] particular discourse can figure at one time as the programme of an institution," Foucault notes, "and at another it can function as a means of justifying or masking a practice which itself remains silent, or as a secondary re-interpretation of this practice, opening out for it a new field of rationality." ${ }^{14}$ It is an assemblage of different ways in which power is practised: "a formation which had as its major function at a given historical moment that of responding to an urgent need ... [that] has a dominant strategic function." 15

Deleuze and Guattari build on Foucault's work by introducing the concept of assemblage, agencement, which denotes "a contingent ensemble of diverse practices and things that is divided along the axes of territoriality and deterritorialisation. Furthermore, particular alignments of technical and administrative practices extract and give intelligibility to new spaces by decoding and encoding milieus. In short, particular assemblages of technology and politics not only create their spaces, but also give diverse values to the practices and actors thus connected to each other." Deleuze and Guattari call any multiplicity of interconnected techniques and actors "a continuous self-vibrating" plateau. ${ }^{16}$

Assemblage is concerned with rhizomatic expansion as well as disaggregated and heterogeneous elements. ${ }^{17}$ Slater argues that assemblage has the same effect as apparatus, but without Foucault's preoccupation with the notion of order. ${ }^{18}$

The concepts of assemblage have been utilized in studies to explore a whole range of issues. Slater, and Haggerty and
(C) Author(s), 2015. This open-access work is licensed under a Creative Commons Attribution-NonCommercial 4.0 International license.
Cette oeuvre en libre accès fait l'object d'une licence Creative Commons Attribution-NonCommercial 4.0 International. 
Ericson employ the terms mobility assemblage and surveillant assemblage respectively to explore issues of surveillance. Haggerty and Ericson argue that the surveillant assemblage ultimately aims to achieve certain finalities, whether economic profit, social control, and/or managing behaviour. ${ }^{19}$ Yet Slater insists that the surveillance and management of circulation is not driven by "an internal logic," but rather expands "to fit the space available." ${ }^{\circ}$ The inconsistency in these bodies of work on assemblage relates to the philosophical tradition underlying the work. Whereas Haggerty and Ericson seem to adopt it in relation to Foucault's concept of apparatus, Slater applies a strict Deleuzian reading.

With that said, Legg argues that it is possible to bring these two terms together. While he acknowledges that Deleuze uses the term to highlight dis-order, he argues that he "also portrayed assemblages as leading to order, striation, re-territorialisation, long-term effects and scaling as much as to dis-order, smoothing, de-territorialisation, short-term effects and de-scaling."21 In this study, I follow Legg's proposition of a shared understanding of apparatus/assemblage. I rely on Tania Li's methodological and theoretical framework adopted in her Practices of Assemblage and Community Forest Management, where she operationalizes the use of assemblage. She identifies six practices that are generic in any assemblage - forging alignments, rendering technology, authorizing knowledge, managing failures, engaging in anti-politics, and reassembling-thus blurring the philosophical difference between apparatus and assemblage. I loosely employ these generic attributes to shed light on "the way in which heterogeneous elements including 'discourses, institutions, architectural forms, philosophical, moral and philanthropic propositions' are assembled to address an 'urgent need' and invested with strategic purpose."22

The appeal of the concept of assemblage, as applied by $\mathrm{Li}$, lies in its practical yet complex analytical contribution. It problematizes the Canadian government's response to the Chilean refugee crisis by highlighting connections, contestations, and tensions between the stakeholders who forged the refugee resettlement, including state actors, Canadian civil society, non-governmental organizations (NGOs), and Chilean refugees. It provides insight into how the Chilean refugees and their resettlement were problematized-that is, diagnosed, framed, and disrupted in response to seen and unforeseen circumstances. Finally, it places government intervention (or the lack of it) within a political, economic, historical, and social context that produced "the actual and the possible." 23 It draws attention to how different forces came together at a particular conjuncture "only to disperse or realign." 24 Drawing on Li's proposed practices, I will consider the unique integration of the forces and relations of power at particular conjunctures in order to reveal the conditions that made the resettlement of the Chilean refugees possible.

In her Along the Archival Grain, Stoler maintains that engaging with the "archive as subject" rather than "source" opens up new avenues for analyzing the past where facts are produced by states in order to contain the reality of governance. ${ }^{25}$ My research project, which relies for the most part on archival material, examines the contradictions and silences in "factual" narratives, examining the conditions of production.

I accessed archival records on Chile at Library and Archives Canada (LAC), the Citizenship and Immigration Canada Library, and Carleton University library. The records, which date from the late 1970 s to early 1975, include letters, memorandums, and reports written by the Canadian ambassador in Santiago, ministers and their deputies, the prime minister, the Cabinet, and the bureaucracy relating to the crisis in Chile. Further, I surveyed reports written by human rights and advocacy groups, including church groups, university professors, unions, and other ordinary Canadians appealing for the resettlement of the Chilean refugees. I also scanned news articles and editorials appearing in Canadian media outlets and used secondary sources on the Chilean refugee crisis.

In reading these documents, I focused on how and why Chilean refugees were securitized and/or humanized. I paid particular attention to the ways different domestic and global forces and events, such as the Cold War, American policy in Latin America, U.S.-Canada relations, the Quebec Crisis, the rise of civil rights movements in Canada and the United States, and Canada's previous response to refugee crises abroad might have shaped this response. I also attended to how this response was implemented and presented publicly and privately; that is, what the government said, how it acted, and what rules it imposed in response to this refugee crisis. The data were analyzed by applying Li's practices of assemblage.

\section{Discussion: Assembling the Government Response to the Chilean Refugee Crisis}

The response of the Canadian government to the Chilean refugee crisis is an assemblage that emerged out of the struggle between actors to achieve their objectives at a particular conjuncture. These actors included government officials, such as the Canadian ambassador in Chile, the minister of immigration and the minister of foreign affairs and other advisors from the department, the RCMP, Immigration and Health and Foreign Affairs, the UNHCR, the New Democratic Party (NDP), Canadian churches, and other civil society groups. Each actor aspired to maintain or increase its power over Canada's economic and political
(C) Author(s), 2015. This open-access work is licensed under a Creative Commons Attribution-NonCommercial 4.0 International license.
Cette oeuvre en libre accès fait l'object d'une licence Creative Commons Attribution-NonCommercial 4.0 International. 
interests in Chile, preserving Canadian unity, ensuring the safety and security of Canadians domestically and abroad, controlling entry to Canada by selecting immigrants who would contribute to its political economy, and resettling Chileans in need of protection.

This response was ultimately a struggle between authorities' will to preserve the security apparatus and their desire to manage the aspirations of (free) citizens to uphold Canada's humanitarian tradition. Drawing on the practices identified by $\mathrm{Li}$, the following four sections map out and analyze how these elements were brought together, highlighting moments of fracture, contradiction, and failure.

\section{Forging Alignments}

Forging alignments, according to Li, refers to the ways in which certain links are assembled to meet the objectives of those "who aspire to govern conduct" and "those whose conduct is to be conducted." 26 For Rose, these links are essential to the logic of liberal government, because they simultaneously reinforce the "autonomy of certain "private' zones" and shape the conduct and "aspirations of free [autonomous] citizens." The autonomy of citizens, Rose points out, needs to "be allied with, and aligned with, such objectives as economic success, national population policy, conceptions of desirability of education and training and the like." 27 That said, the work of forging alignments is also fragile, because it requires the negotiation of conflicting demands and interests. ${ }^{28}$

Forging alignments between actors in this assemblage was not straightforward, as it underlined different aspirations, values, and interests. Upon winning the federal election in 1968, Pierre Elliot Trudeau clarified that promoting national unity and Canadian economic interests abroad were his priorities. ${ }^{29}$ Domestically, Trudeau was concerned with Quebec's bid for independence, and with the growing prominence of the Front de libération du Québec (FLQ), which he saw as a terrorist group in part because of its involvement in the kidnapping of the British trade commissioner and the Quebec minister of labour in October 1970. It was claimed that the FLQ had been trained by antiimperialist movements in Latin America, whose "terrorist" tactics it had ostensibly used. $3^{\circ}$

To deal with the challenge of the FLQ, the government entrusted the RCMP with monitoring and controlling the activities of Quebeckers domestically and abroad. The RCMP also worked closely with Canadian immigration officials abroad to ensure the selection of individuals who contributed to Canada's Western liberal democratic values and the exclusion of others who were perceived as threatening those values.

Meanwhile, Quebec had well-established ties to Latin America. These ties were largely due to surplus Catholic priests who left during the Quiet Revolution for the predominately Catholic Latin America, which was experiencing a shortage of priests. Quebec perceived the presence of these priests as "a reinforcement of its 'special status' as a 'Latin' region of North America," and as "projecting the French reality in the Americas." ${ }^{11}$ Further, the Comite de Solidarité Québec-Chili, which was established shortly after the coup, made an immediate connection between the struggle of Quebeckers and the Chilean people: "In Québec, we had the War Measures Act and Bill 19, followed by the imprisonment of union leaders. Our 'democracy' cites national security and essential services as its justification; the military junta invokes security and national reconstruction." 32 This connection, along with the religious and cultural association with Chile, was the basis for the "quick mobilization in Québec."33

While this connection forged an alignment between Quebec and refugees from Chile, it also presented fracture lines. It threatened the Canadian government's aspiration to control Quebec's independence, and to allow the entry of individuals who were perceived as unfit for its Western liberal values. The alignment of Chilean refugees in need of protection and the Canadian government was further compounded by Canada's economic interests. These interests were managed by Mitchell Sharp, the minister of external affairs, who "emerged as a business-like manager of Canadian foreign policy." 34 Sharp conceived relations between Latin America and Canada as centred solely on economic interests and ensured that diplomatic postings abroad reflected this priority. 35

As Chileans and other nationals were fleeing Pinochet's violence and persecution, the Canadian government was negotiating trade and debt-reduction agreements with Pinochet. Once Pinochet seized power, imports from and exports to Chile increased substantially. In fact, the Canadian Export Development Corporation Department even sold Pinochet military equipment, including de Havilland aircraft, for $\$ 5$ million. ${ }^{6}$ Canada also endorsed the InterAmerican Development Bank (IADB) in granting the Chilean government loans totalling \$100 million, when Nordic countries refused to approve similar loans. ${ }^{37}$

Canadian economic interests in Chile were preserved and coordinated by the Canadian ambassador to Chile, Andrew Ross, who later emerged in the eyes of the Canadian public as the architect of the government's decision not to immediately intervene in protecting Chileans, and hence as an unsympathetic figure. Ross's dislike of Allende and his supporters, and his unequivocal support of Pinochet, was clearly articulated in his letters to the office of External Affairs in Ottawa. These exchanges revealed that the Canadian government was less concerned with the fate
(C) Author(s), 2015. This open-access work is licensed under a Creative Commons Attribution-NonCommercial 4.0 International license.
Cette oeuvre en libre accès fait l'object d'une licence Creative Commons Attribution-NonCommercial 4.0 International. 
of Chileans, and more with the economic interests that might be capitalized on by Chile's change of government. ${ }^{38}$ Ross expressed his resistance to any resettlement initiative due to the Chilean refugees' "culture," and its implications for Canadian commercial relations with Chile. "It would be most unwise to officially deliver homilies on [the] virtues of democracy as we practice it under entirely different conditions ... [and] counter-productive in terms of our political and commercial relations with Chile," he wrote in a Telex to External Affairs. 39

That said, the ambassador delivered what the government wanted to hear. Ross was diligent in briefing the minister's office on the situation in Chile, including his intention to prevent people from entering the embassy. ${ }^{40}$ With the encouragement of the Ministry of External Affairs, Ross sought to secure Canadian interests, which incidentally involved closing the door on people in immediate need of protection.

The conditions that made it possible for Canada to maintain its economic interests in Chile, and to exclude Chileans from protection, were slowly being fractured, allowing more space for public discontent. Indefatigable priests and bishops who witnessed first-hand the atrocities committed by Pinochet during their service in Chile contested the narrative of the government. Upon returning to Canada, they exposed these atrocities, along with the Canadian government's attitudes toward Pinochet, to the broader Canadian public. ${ }^{41}$ These clergymen, whose churches had been involved in government resettlement schemes since the Second World War, also put intense pressure on the government to resettle Chileans. The testimonies of these clergymen were echoed and supported by Amnesty International's report published in December 1973, which exposed state repression, torture, and human rights violations.

Other segments of Canadian society, including unions, university professors and students, and human rights groups rallied behind church groups, thus forging a stronger alignment with the Chilean refugees. ${ }^{42}$ This organic mobilization was due not only to the intervention of church groups, but also to the socio-political environment in which the Chilean crisis occurred. Between the late 1960 s and early 1970s, anti-American sentiments were rising among Canadians who disapproved of the Vietnam War, anti-communist ideology, and U.S. imperialist policy in Latin America. Mainstream civil society groups, including academics and church groups, contested the designation of certain groups who resisted colonial and imperial powers as terrorists, when other European refugees from communist regimes were perceived as freedom fighters.

The NDP, which held the balance of power in the minority Liberal government, was also very critical of the government's response to the crisis in Chile. It was vocally opposed to the recognition of the junta. It also urged the government to recognize diplomatic asylum and expedite the resettlement of Chileans. Most notably, the NDP leaked confidential cables, written by the Canadian ambassador in Chile to the Department of External Affairs, to the media. In these cables Ross described the Chileans as "riff raff" and noted that Pinochet brought an end to the "political madness" of the Allende government. 43

The leaks seriously damaged the government's credibility on the issue of the Chilean refugees, exposing official indifference to human suffering. The minister of external affairs did not explicitly defend his ambassador's actions, which inadvertently implied that the ambassador acted alone. The government's decision to finally intervene aimed to address its failure to properly manage knowledge and accurately assess the growing role of civil society in refugee protection issues.

\section{Managing Failures and Contradictions: Framing the Arena of Intervention}

$\mathrm{Li}$ addresses managing failures to the "outcome of rectifiable deficiencies" and the means through which compromises are devised. Contradictions in this case are viewed as "superficial," but not "fundamental." Framing is particularly important in managing "the unruly array of forces and relations," and in producing an intervention with "optimal arrangements." The technical solutions authorized by the government to deal with failures "present simplified narratives of problem/solution that gloss over tensions to make the assemblage appear far more coherent than it is." 44

Despite the appeal of Canadian church groups in the first few weeks of the crisis, government authorities limited the number of refugees entering the embassy and publicly downplayed the crisis in Chile. Based on instructions from External Affairs, the ambassador in Chile applied a narrow interpretation of protection. Individuals were allowed entry into the embassy if they proved that their lives were in immediate and imminent danger. 45 The government was also careful in the ways it framed the refugee crisis in Chile to the public. A memorandum written to the minister of external affairs on 12 October 1973 suggested that the minister should refrain from using the term refugee or refuge, further explaining,

It has become evident that the use of the term "refugee" may cause problems because of the potential abuse by persons seeking admission to Canada of claims to refugee status ... It would be most desirable in statement or in response to questions in the House, therefore, to avoid use of the word "refugee" entirely when referring to the Chilean situation or to the fifteen who have
(C) Author(s), 2015. This open-access work is licensed under a Creative Commons Attribution-NonCommercial 4.0 International license.
Cette oeuvre en libre accès fait l'object d'une licence Creative Commons Attribution-NonCommercial 4.0 International. 
come forward to Canada. "Persons affected by the coupe," "those who took shelter," or some such phrase, would be an acceptable alternative. It might also be helpful to refer to "shelter" rather than "refuge." 46

With growing public pressure and the exposure of the diplomatic cables, the Canadian government had very little choice but to reveal an action plan. To deal with this crisis of confidence, the government deployed a senior official from External Affairs, and another from the Department of Manpower and Immigration, on 19 November 1973 to Chile and neighbouring countries to assess the needs of refugees. In reporting back to the government, the officials pointed out that the fear of death and detention was still high. They advised the government to adopt a humanitarian approach to meet the needs of vulnerable individuals. This approach, they pointed out, needed to take into account public expectations in light of Canada's humanitarian tradition, the risks and inconveniences that refugees might pose to Canadians and Canada's interests, and implications for immigration policy. 47

Stevenson notes that the report was "crucial in forging a new program to bring Chileans to Canada." 48 By adopting this program, the government opted to revise its attitudes to meet new conditions of formation that took into account the desires and aspirations of civil society. Nonetheless, the government imposed new technologies of control through rigid screening, which was presented as essential in eliminating threats to Canadians and their democratic institutions. That said, selection became the "site of contestation" among stakeholders.

The first special measure adopted by the government targeted the resettlement of 300 to 1,000 refugees and "oppressed persons," both Chilean and non-Chilean, inside and outside of Chile, by February 1974. The second offered a special protection operation to be completed by 2 January 1974 for a single group of fifty Chileans who were at risk of harm or long-term detention, and were not registered with the UNHCR. This humanitarian intervention, noted Andras, aimed to "meet genuine feeling and deep humanitarian concern which continue to be conveyed ... by many Canadians and in particular church leaders." He also pointed out that the provisions adopted toward the Chilean refugees would be "comparable to those applied to the past movements to Canada." 49

Unlike the Ugandan-Asian resettlement the previous year, which involved no security screenings, the instructions from the minister's office insisted that Chileans and other nationals considered for resettlement undergo strict security screenings to exclude "known terrorists and persons with serious non-political criminal records."5o
"Chilean refugees seeking landed immigrant status in Canada," added the minister in a telephone interview with the Toronto Star on 3 December 1973, "will be refused admission if their political beliefs lead to violence." ${ }_{1}$

The framing of the Chilean refugees as endangering the well-being of Canadians and their institutions was essential in justifying exclusionary practices. In a letter to the prime minister justifying the rigid security screening, Andras emphasized his responsibility to protect Canadians: "The decision to admit people to our embassy would not be an immigration decision but any problems that subsequently result would certainly become my responsibility ... [P]art of that responsibility is the protection of residents of Canada from the admission of persons who represent serious threats to security and order." 52

Andras also reiterated the public danger posed by Chileans: "[There will be] hell to pay in this country [over the decision to admit Chileans to Canada]," he declared. "Yes, there are Marxists among them, I suppose ... We think we've screened out anybody who really wants to import violent overthrow of the Canadian government." 53

The framing of the Chileans as dangerous justified the formulation and adoption of rigid security and immigration screenings. Thus once the Canadian ambassador was no longer credible in the public eye, the power to decide matters of life and death was handed over to the minister of immigration, the RCMP, and immigration and health officials. The legislation implemented by the minister of immigration, which was framed in terms of humanitarian concern with suffering and loss of life, aimed, along with immigration and health officials' screening processes, to select refugees who demonstrated an ability to integrate into Canadian society and the labour market, and not to burden Canada's welfare system or endanger public health. The Chilean refugee crisis became a technical, "anti-political" issue subject to immigration and security screenings.

\section{Anti-Political Practices and Authorized Knowledge}

I use the term anti-political in Li's sense. She uses it to refer to the ways in which political questions become a matter of technique when dismissing or limiting debate on "how and what to govern and the distributive effects of particular arrangements by reference to expertise." The government's assembled humanitarian response, which involved the discretionary power of the minister along with a series of legislative and other practices, was presented as having the neutral objective of remedying human suffering. The screening processes of immigration and health officials, and the RCMP, were treated as a technical means to achieve this humanitarian goal while protecting the safety and security of Canadians. The success of this assemblage was
(C) Author(s), 2015. This open-access work is licensed under a Creative Commons Attribution-NonCommercial 4.0 International license.
Cette oeuvre en libre accès fait l'object d'une licence Creative Commons Attribution-NonCommercial 4.0 International. 
determined by the authorization of knowledge, which for $\mathrm{Li}$ refers to "specifying the requisite body of knowledge; confirming enabling assumptions; containing critique." 54

Institutions are carriers of ideas and collective memories. ${ }^{55}$ These ideas and memories are essential in understanding RCMP activity in Chile. In 1946, Canada's prime minister, Mackenzie King, created the RCMP with the sole mission of preventing communist infiltration into Canada. ${ }^{56}$ By the early 1970 s the RCMP was also charged with closely monitoring FLQ activities. The RCMP enjoyed great discretionary power and autonomy, and operated with considerable secrecy and scant accountability to the public. It was only in the early 1980 s, following the publication of the McDonald report, which investigated the RCMP's alleged involvement in illegal activities in Canada, that the RCMP's power was scrutinized.

While RCMP activities in Canada were exposed and eventually scrutinized, the extent of its activities abroad, which largely affected refugees, was never explored. Where refugees were concerned, the RCMP had full power over life. "For all intents and purposes," Agamben notes, "the normal rule of law is suspended and ... the fact that atrocities may or may not be committed does not depend on law but rather on the civility and ethical sense of the police that act temporarily as sovereign." 57

The RCMP was in full command of the security screenings of Chileans. It based its decisions on information from foreign intelligence, including the CIA, which incidentally assisted Pinochet in toppling the Allende regime. ${ }^{58}$ From the RCMP's perspective, the Chilean refugees were exactly the kind of immigrants that Canada needed to avoid. They were the most dangerous, as they represented the combined threat of communism and Quebec separatism. They were also associated with and supported by unions, academics, students, and progressive church groups in Quebec-the same groups that the RCMP had been monitoring in Canada out of fear of communist or FLQ infiltration. Given the mission and history of the RCMP, it is not surprising that the security screenings of the RCMP were the primary reason for the delays in processing the applications of the Chilean refugees, and the high rate of rejection. Among the 2,321 applications received by 4 January 1974, only 109 persons received immigration visas. 59

Despite the relaxed immigration criteria, Chileans still needed to demonstrate their ability to integrate into Canadian society in accordance with Canada's point system. The point system was adopted in 1967 to deal with the growing need for technical and industrial economies, and to officially eliminate previous racist rules that gave preference to European immigrants. This system, which remains the primary instrument for immigrant selection, decided immigrant selection on the basis of family ties, language acquisition, job skills, and education. Individuals were awarded a maximum number of points in each category. The system, which was adopted in the name of liberalism, justice, diversity, and equal opportunity, along with the administrative measures dealing with immigration offices abroad, micromanaged immigrants' entry to Canada.

Although the adoption of the point system was framed as a departure from previous racist policy, it demonstrated a new form of racism. It employed "cultural racism" where certain cultures that promoted Western liberal and individualistic values were welcomed in Canada. "The cultures supposed implicitly superior," notes Balibar, "are said to be the cultures whose 'spirit of community' is constituted by individualism." ${ }^{\text {"60 }}$ As a result of the (somewhat relaxed) point system, the resettled Chileans who came to Canada were, as Andras commented, "young, well-educated and adaptable people who, with a little help, can be expected to add their contribution to the richness and variety of Canada." ${ }^{\prime 61}$

Whereas the RCMP sought to eradicate communist and Quebec separatist threats, immigration and health officials were eager to screen and select for adaptable immigrants who would contribute to Canada's economy and whose lives were at risk. These goals were not fully compatible with each other. The RCMP's concerns with securing Canada's political survival at times contradicted immigration offcials' humanitarian mission. Many Chileans who urgently needed immigration officials' humanitarian intervention were exactly the refugees that the RCMP was screening out. This inherit contradiction was fundamental in glossing over the Canadian government's aim of controlling the entry of Chileans.

\section{Reassembling}

Reassembling involves "grafting on new elements and reworking old ones" by employing new discourses to old ones and changing meanings and key terms. ${ }^{62}$ The assemblage of power created to control the Chilean refugees in this early period influenced the Canadian government's responses and attitudes to other refugee crises abroad.

This crisis revealed the emergence of civil society as a powerful actor in challenging the practices of the government in refugee crises abroad. Prior to this, civil society had very little influence on immigration and refugee policies and practices. ${ }^{63}$ Hanff asserts that the resettlement of the Chilean refugees marks a fundamental shift in the role that civil society plays in crucial foreign policy issues: "The Canadian government took this decision, not because its stability was threatened, but rather because the high profile of the activists and the visibility of the pressure threatened an image that Canadians and non-Canadians seem to have
(C) Author(s), 2015. This open-access work is licensed under a Creative Commons Attribution-NonCommercial 4.0 International license.
Cette oeuvre en libre accès fait l'object d'une licence Creative Commons Attribution-NonCommercial 4.0 International. 
about Canada. At its narrowest, this image could be defined in terms of Canada's so-called refuge-thinking tradition. In its broadest context, it is defined in terms of Canada's internationally responsible attitude." 64

For the first time, governing authorities needed to actively engage with civil society in order to manage expectations, especially when refugees did not conform to the governing authorities' desires. The growing role of civil society was reflected, for example, in the decision of the minister of manpower and immigration to conduct coast-to-coast public consultations on immigration issues in 1973. The assembled "partnership" between civil society groups and the government was framed as a humanitarian and nonpolitical response. Since then, refugee reception has been presented as a negotiated compromise, not as reflecting the sole vision of the government.

Further, in light of the Chilean and Ugandan-Asian resettlement, the government incorporated the "designated classes" provision into the 1976 Immigration Act. Canadian policy-makers believed that the Refugee Convention definition was not encompassing enough to include individuals who did not cross internationally recognized boundaries, and whose "collective situation placed them in a de facto refugee situation." 65 Under this category, persons who are able to successfully establish themselves in Canada are issued landed immigrant visas. "The sponsorship allocation statistics," Hathaway writes, "give the impression of a larger Canadian contribution to the relief of the international refugee burden than is actually the case." 66 The number of "refugees" sponsored under this category is included in the annual refugee quota allocated by the government when many are not refugees at all.

Moreover, while the government insisted that this provision aimed to provide flexible tools in responding to humanitarian needs, Hathaway points out that this designated class reflects not only economic but also political considerations. ${ }^{67}$ This issue was raised in a motion to amend the admissibility section 19 (e) of the 1976 Immigration Act. The amendment sought to ensure that there is "no distinction among refugees, fleeing rightist or leftist persecution."68 The minister of employment and immigration rejected the amendment on the basis of security concerns:

It is difficult to see how most provisions respecting subversion and national security could be reconciled with the proposed amendment. No political party is illegal in Canada, yet membership in a particular party abroad, where it is probably legal is often the principle evidence that a person is a security risk. With the amendment it would appear that the subversion/security provisions could apply only in the case of an overt act defined as an offence in Canadian law. This would be going too far in the case of refugees. It would effectively prevent the screening out of people, although refugees by definition, who were forced to leave their countries of citizenship or residence because of their adherence to parties with extremist policies, which would be just as dangerous in Canada as elsewhere. ${ }^{69}$

The minister's objection to the amendments proves that the security mechanisms enacted toward refugees are essential and justified, and intimately connected to the government's political goals.

\section{Conclusion}

The study aims to shed light on how the Canadian government assembled its response to the Chilean refugee crisis in the first few months of the coup, and the conditions that made the Chilean refugee resettlement possible. It argues that despite the Canadian government's humanitarian claims, fear and (in)security framed and defined its approach to refugee protection. Such fear and (in)security gave rise to a complex nexus of power that shaped the Chilean refugee resettlement.

The study contributes to scholarly literature in three ways. First, it adds to a theory and methodology of practice in the field of refugee studies. It adopts the concept of apparatus/ assemblage to practice, and thus highlights the complexity involved in responding to refugee crises. By applying practices of assemblage, the article exposes how different forces and relations of power are assembled and reassembled to control the entry of refugees. It also shows how exclusion from protection is managed through the articulation and re-articulation of knowledge and power, and functions through the circulation of fear and anxiety. This understanding is pivotal in understanding how current refugee policies and practices are shaped.

Second, the article challenges the assumption that Canada's response to the Chilean refugees was influenced by the United States. My research found very little evidence to support this claim. Thus, the article contributes to new knowledge by emphasizing the Canadian government's independence in managing its response to this crisis.

Third, the article highlights the strengths and limitations of civil society in challenging government practices. The limited success of civil society in this resettlement points to the power of the security apparatus in deciding which lives are worth living. Yet it also underlines the potential of civil society to resist this apparatus. Civil society capitalized on public spaces, such as universities and churches, and exposed knowledge that the government had tried to conceal; it was therefore able to galvanize support and challenge government practices. However, since the 1970 s this public voice has been slowly institutionalized by being
(C) Author(s), 2015. This open-access work is licensed under a Creative Commons Attribution-NonCommercial 4.0 International license.
Cette oeuvre en libre accès fait l'object d'une licence Creative Commons Attribution-NonCommercial 4.0 International. 
made a partner in decision-making. Hence government practices toward refugees have been presented as a compromise between competing public interests.

Future studies could explore further the tension between Canadian civil society and the security apparatus that seeks to impose the vision and desires of Canadian governing authorities. The question must be asked: Does this partnership hinder or facilitate refugee protection?

Suha Diab received her PhD in public policy and political economy from Carleton University in 2014. She is broadly interested in migration, security, and humanitarianism, especially policies and practices of inclusion/exclusion. The author may be contacted at suhadiab@hotmail.com.

\section{Notes}

1 Joan Simalchik, "The Material Culture of Chilean Exile: A Transnational Dialogue," Refuge 23 (2006): 95-105.

2 George Hanff, "Decision Making under Pressure: A Study of the Admittance of Chilean Refugees to Canada," North/ South 6 (1979): 116-35.

3 See Gerald E. Dirks, Canada's Refugee Policy: Indifference or Opportunism? (Montreal and Kingston: McGillQueen's University Press, 1979); Harold Troper, “Canada's Immigration Policy since 1945," International Journal 48 (1993): 255-81; Reginald Whitaker, Double Standard: The Secret History of Canadian Immigration (Toronto: Lester \& Orpen Dennys, 1987).

4 See John F. Duggan, "Live Again in Community: Hispanic Refugees and the Church," Refuge 13 (1994): 19-25; also Valerie Knowles, Strangers at Our Gates: Canadian Immigration and Immigration Policy, 1540-1990, 3rd ed. (Toronto: Dundurn, 2007); Alan B. Simmons, "Latin American Migration to Canada: New Linkages in the Hemispheric Migration and Refugee Flow System," International Journal 48 (1993): 282-309.

5 Francis Peddie, Young, Well-Educated and Adaptable: Chilean Exiles in Ontario and Quebec, 1973-2010 (Winnipeg: University of Manitoba Press, 2014).

6 Ibid., 12.

7 Ibid.

8 "Recognition of the New Regime in Chile," memorandum to the minister, 27 September 1973, Political Affairs-Independence and Recognition-Chile, vol. 1, RG 25, Library and Archives Canada (LAC).

9 Mitchell Sharp, Which Reminds Me ... A Memoir (Toronto: University of Toronto Press, 1994), 172.

10 James F. Rochlin, Discovering the Americas: The Evolution of Canadian Foreign Policy towards Latin America (Vancouver: University of British Columbia Press, 1994).

11 On "cultural racism," see Etienne Balibar, "Is There a 'NeoRacism'?," in Race, Nation, Class: Ambiguous Identities, ed.
Etienne Balibar and Immanuel Maurice Wallerstein (London: Verso, 1991), 25-6.

12 Ross to External Affairs, "Special Operation," 11 December 1973, file 20-15-Chile-30-49, vol. 1, Political Affairs-Political Asylum, RG 25, LAC. See also Tanya Basok and Alan Simmons. "Refugees in Canada: A Review of the Politics of Refugee Selection," in Global Refugee Crisis: British and Canadian Responses, ed. V. Robinson, 132-57 (London: Oxford University Press, 1993).

13 Michel Foucault, Power/Knowledge: Selected Interviews and Other Writings, 1972-1977 (New York: Pantheon, 1980), 194.

14 Cited in Didier Bigo, "Globalized (in)Security: The Field and the Ban-Opticon," in Illiberal Practices in Liberal Regimes: The (In)Security Games, ed. Didier Bigo and Tsoukala Anastassia (New York: Routledge, 2006), 33.

15 Foucault, Power/Knowledge, 196.

16 Aihwa Ong, "Ecologies of Expertise: Assembling Flows, Managing Citizenship," in Global Assemblages: Technology, Politics and Ethics as Anthropological Problems, ed. Aihwa Ong and Stephen J. Collier (Oxford: Blackwell, 2004), 338.

17 See Gilles Deleuze and Félix Guattari, A Thousand Plateaus: Capitalism and Schizophrenia, trans. Brian Massumi (Minneapolis, MN: University of Minnesota Press, 1987).

18 Mark B. Slater, "To Make Move and Let Stop: Mobility and the Assemblage of Circulation," Mobilities 8 (2013): 7-19.

19 Kevin D. Haggerty and Richard V. Ericson, "The Surveillant Assemblage," British Journal of Sociology 51 (2000): 605-22.

20 Slater, "To Make Move and Let Stop," 14.

21 Stephen Legg, "Assemblage/Apparatus: Using Deleuze and Foucault," Area 43 (2011): 129.

22 Tania M. Li, "Practices of Assemblage and Community Forest Management," Economy and Society 36 (2007): 264.

23 Colin McFarlane, "Assemblage and Critical Urban Praxis: Part One-Assemblage and Critical Urbanism," City 15 (2011): 204.

$24 \mathrm{Li}$, "Practices of Assemblage," 265.

25 Ann L. Stoler, Along the Archival Grain: Epistemic Anxieties and Colonial Common Sense (Princeton: Princeton University Press, 2009), 93.

$26 \mathrm{Li}$, "Practices of Assemblage," 265.

27 Nikolas Rose, Powers of Freedom: Reframing Political Thought (Cambridge: Cambridge University Press, 1999), 50.

28 Li, "Practices of Assemblage," 266.

29 David D. Dewitt, and John J. Kirton, Canada as a Principal Power: A Study in Foreign Policy and International Relations (Toronto: John Wiley, 1983).

30 Peter C. Dobell, Canada's Search for New Roles: Foreign Policy in the Trudeau Era (Toronto: Oxford University Press, 1972), 49.

31 Rochlin, Discovering the Americas, 11.
(C) Author(s), 2015. This open-access work is licensed under a Creative Commons Attribution-NonCommercial 4.0 International license.
Cette oeuvre en libre accès fait l'object d'une licence Creative Commons Attribution-NonCommercial 4.0 International. 
32 Cited in Brian J. Stevenson, Canada, Latin America, and the New Internationalism: A Foreign Policy Analysis, 19681999 (Montreal and Kingston: McGill-Queen's University Press, 2000), 192.

33 Ibid., 192-3.

34 Dobell, Canada's Search for New Roles, 49.

35 Sharp, Which Reminds Me, 172.

36 "Chile Report-Enterprise and Repression," MG28-I270-58, LAC.

37 "Summaries of Discussions at Meetings of the Board of Directors of IFC and the Executive Directors of the Bank and IDA," February 5 1974, World Bank Group-IBRD/IFC/ IDA-Relations with Member Countries-Chile, file 1-20, Volume 32, R200, LAC.

38 Ross described the killing in Chile as "abhorrent but understandable." See "Chile: Bloodletting," 20 September 1973, file 20-22-5-Chile-38-28, RG 25, LAC.

39 Ross to External Affairs, "Canada-Chile Relations," 1 November 1973, Telex, vol. 986, RG 76, LAC.

40 Ross also excelled on his yearly performance evaluation report until diplomatic exchanges between Ross and External Affairs were leaked to the media in November 1973. See A.D. Ross. Career. Employment Evaluations, 1972-1977, file 1, vol. 6, Chile, D-MG 31 E 67, Ross, Andrew, LAC.

41 Several archival documents describe church group visits to meet the ambassador to Chile and other government officials in Ottawa, who were urged to resettle more Chileans.

42 This is not to say that Canadian civil society was unified in this response. Many letters to the editor expressed concern about this resettlement.

43 Michael Lavoie, "Canadian Envoy's Cables Say Killings in Chile 'Abhorrent But Understandable,"' Toronto Star, 6 November 1973.

$44 \mathrm{Li}$, "Practices of Assemblage," 271.

45 "Chile-Refuge," 25 October 1973, file 20-15-Chile, Political Affairs-Political Affairs-Political Asylums-Chile, RG 25, LAC.

46 "The Situation in Chile Reference to 'Refugees,"' 12 October 1973, Memorandum for the Minister, vol. 9409, Political Affairs-International Security-Coup D'etat-Chile, RG 25, LAC.

47 "Report on Visit to Chile," 24 November 1973, file 20-15Chile, Political Affairs-Political Affairs-Political Asylums-Chile, RG 25, LAC.

48 Stevenson, Canada, Latin America, and the New Internationalism, 130.
49 "Memorandum to the Minister: Special Operation," 4 December 1973, vol. 9337, Political Affairs-Political Asylum-Chile, RG 25, LAC.

50 Ibid.

51 "Andras Says We Won't Admit Trouble-Making Chileans," Toronto Star, 3 December 1973.

52 "My Dear Prime Minister," 30 November 1973, file 20-15Chile, Political Affairs-Political Asylum-Chile, RG 25, LAC.

53 "Andras Says There Will Be Hell to Pay over Decision to Admit Chile Refugees," Toronto Star, 21 January 1974.

54 Li, "Practices of Assemblage," 265.

55 Vivien A. Schmidt, "Discursive Institutionalism: The Explanatory Power of Ideas and Discourses," Annual Review of Political Science 11 (2008): 303-26.

56 Freda Hawkins, Canada and Immigration: Public Policy and Public Concern, 2nd ed. (Montreal and Kingston: McGill-Queen's University Press, 1988).

57 Giorgio Agamben, Means without End: Notes on Politics, trans. Vincenzo Binetti and Cesare Casarino (Minneapolis, MN: University of Minnesota Press, 2000), 42.

58 "Transcript of Interview by Brian Steward of СвС with Solicitor-General," 10 January 1974, vol. 9337, Political Affairs-Political Asylums-Chile, RG 25, LAC.

5926 December 1974, vol. 9337, Political Affairs-Political Asylum-Chile, RG 25, LAC.

60 Balibar, "Is There a 'Neo-Racism'?," 25-6.

61 Church groups quickly realized and contested this selection bias. In an interview with the a Toronto researcher for the United Church of Canada noted, "In dealing with the plight of refugees the government "has been hiding behind the applications from middle class people."' See "Churches Ask Sharp to Take Chileans," Toronto Star, 27 December 1973.

$62 \mathrm{Li}$, "Practices of Assemblage," 265.

63 Louis Parai, "Canada's Immigration Policy, 1962-74," International Migration Review 9 (1975): 449-77.

64 Hanff, "Decision Making under Pressure," 129.

65 Michael C. Lanphier, "Canada's Response to Refugees," International Migration Review 15 (1981): 198-211, 117.

66 James C. Hathaway, "Selective Concern: An Overview of Refugee Law in Canada," McGill Law Journal 33 (1988): 698.

67 Ibid.

68 Cited in Rhonda Howard, "Contemporary Canadian Refugee Policy: A Critical Assessment," Canadian Public Policy 6 (1980): 371.

69 Ibid.
(C) Author(s), 2015. This open-access work is licensed under a Creative Commons Attribution-NonCommercial 4.0 International license.
Cette oeuvre en libre accès fait l'object d'une licence Creative Commons Attribution-NonCommercial 4.0 International. 
(C) Author(s), 2015. This open-access work is licensed under a Creative Commons Attribution-NonCommercial 4.0 International license.
Cette oeuvre en libre accès fait l'object d'une licence Creative Commons Attribution-NonCommercial 4.0 International. 


\title{
Invisible Lives and Hidden Realities of Undocumented Youth
}

\author{
FARIA KAMAL AND KYLE D. KILLIAN
}

\begin{abstract}
This qualitative study explored the lived experiences of undocumented youth and the mental health impacts of living in daily fear of detention and deportation. In-depth, semi-structured interviews were conducted to examine the repercussions of living without immigration status, and the descriptive data were analyzed using a grounded theory approach. Results indicate that lack of immigration status is associated with mental health issues, particularly anxiety. Absence of immigration status is implicated as a decisive social factor influencing individuals' mental and social well-being.
\end{abstract}

\section{Résumé}

Cette étude qualitative portait sur les expériences vécues des jeunes personnes sans papiers et les impacts en matière de santé mentale de vivre quotidiennement dans la peur d'être détenu ou déporté. Des entrevues en profondeur semi-structurées étaient effectuées afin d'examiner les répercussions de vivre sans statut d'immigrant, et les données descriptives étaient analysées selon une théorie à base empirique. Les résultats indiquent que l'absence de statut d'immigrant est associée à des problématiques de santé mentale, surtout l'anxiété. Le fait de ne pas avoir un statut d'immigrant est donc considéré comme un facteur social décisif qui influe sur le bien-être mental et social des individus.

\section{Introduction}

Tmmigration status, or lack thereof, is an important determinant of mental health and social well-being. ${ }^{1}$ Undocumented or non-status immigrants live in
Canada without full, permanent legal immigration status, such as individuals who have fallen completely out of status without recourse and individuals obtaining temporary work permits, student permits, permanent residency, or humanitarian and compassionate permits, but who do not have status, despite being formally engaged with the immigration and refugee system. Non-status persons confront a wide range of mental health issues, but as the result of restrictive public policies are rarely accorded the opportunity to access health care, education, and myriad other vital social services. ${ }^{2}$ Although the terms undocumented and non-status are used interchangeably in research to reference the same population, this article will use the term undocumented for the sake of consistency.

In Canada, conservative estimates hold that there are more than 500,000 undocumented immigrants, over 80,000 of whom reside within the Greater Toronto Area. ${ }^{3}$ Because the size of this population is so very large, it is imperative to explore the mental health concerns that may arise from living in daily fear of detention and deportation in an attempt to better formulate public health policies that address the needs of undocumented residents. Given that studies on undocumented adolescents have rarely been conducted in Canada, this study aimed to help bridge the gaps in literature and knowledge on how lack of immigration status affects youth. In particular, this study investigated what it means to be undocumented and how living without legal immigration status informs undocumented youths' sense of identity, general mental health, and social integration.

\section{Review of the Literature}

Scant literature explores the lives of undocumented residents in Canada and most countries of the Global North, which have, in recent decades, become home to significant numbers of undocumented migrants. ${ }^{4}$ This lack of research
(C) Author(s), 2015. This open-access work is licensed under a

Creative Commons Attribution-NonCommercial 4.0 International license.
Cette oeuvre en libre accès fait l'object d'une licence Creative Commons Attribution-NonCommercial 4.0 International. 
is attributed largely to the fact that undocumented migrants actively and quite consciously remain hidden from public view in order to avoid detection and deportation. 5 Although the inability of most researchers to access such populations remains the most pronounced reason that there are only the scantiest research data, several other factors may deter studies of undocumented residents. Historically, governments in the Global North, and their respective research institutions (including public universities), have been highly critical of funding any research projects involving "illegal" populations, whose presence within the host country is often denied outright or ignored by the government. ${ }^{6}$ Investigators from various disciplines contend that the lack of funds available for this research is politically motivated because the state, along with multinational corporations, has an invested economic interest in ensuring that undocumented populations remain outside the ambit of conventional scientific inquiry because such scrutiny could reflect poorly on state policy and ideologies.7 Such proponents further assert that government commissions such as the United States Select Commission on Immigration and Refugee Policy make erroneous statements about the nature of this population and why research with such populations is unfeasible and, ultimately, not eligible for government funding. ${ }^{8}$ For example, the U.S. Commission on Immigration and Refugee Policy made a public declaration against fieldwork with undocumented migrants, stating that the impacts of "illegal immigrants are basically unknown and unknowable" and thus research of this population would not be funded. 9 This, coupled with the fact that there is no way to have a strict randomized sample on a large clandestine population, makes fieldwork in the area particularly complex, time-consuming and challenging. Despite such obstacles, researchers have conducted research with this population, which will be reviewed below.

\section{Brief Overview of How People Become Undocumented}

Contrary to popular discourse, which paints undocumented peoples as covertly entering Canada through illicit or illegal means, almost all undocumented peoples enter Canada with some kind of legal status, including work permits and visas. ${ }^{10}$ However, they are often unable to live with status after these permits and visas expire, as Canada's immigration system systematically privileges specific types of immigrants over others, prioritizing well-educated, upper-middle class individuals. ${ }^{11}$ As a result, those individuals entering Canada through temporary work programs in service and labour industries or through travel visas are unable to garner enough points to qualify under Canada's Immigration Point System. ${ }^{12}$ Furthermore, refugees claimants are systematically denied status since over half are outright denied. ${ }^{13}$ Consequently, many individuals, after being denied legal status, make the difficult choice to stay in Canada as an undocumented migrant. Since the focus of this paper is on adolescents, it is necessary to make salient the fact that although adult immigrants choose to relocate to Canada for myriad economic and political reasons, children and youth do not have the same choice, as they usually immigrate because their parents have made the decision on their behalf. As such, youth do not possess the same level of autonomy and agency as their adult counterparts in decisions regarding migration.

\section{General Health of Undocumented Immigrants}

Congruent with research on other marginalized groups in society, undocumented immigrants have numerous health needs that are not met, especially mental health services, which are rarely, if ever, offered. ${ }^{14}$ Moreover, their needs are frequently ignored by mainstream health professionals, most of whom are not trained to respond to such concerns or are ill-equipped to do so, restricted by financial and institutional barriers. ${ }^{15}$ In general, health security-referring to the concept of personal safety, protection from health risks, and ability to access health care in a timely manner-for undocumented residents tends to be extremely precarious. ${ }^{16}$ This void is largely the result of public policies that excise undocumented peoples from accessing municipal, provincial, or federal resources, as access is directly contingent upon having legal status. ${ }^{17}$

Consequently, undocumented residents have higher rates of illness and hospitalization because their lack of health insurance coverage prevents them from receiving care when smaller health concerns arise. ${ }^{18}$ Furthermore, undocumented immigrants have higher incidences of being hospitalized for more serious, life-threatening concerns than conventional immigrants with legal status. ${ }^{19}$ This disparity is attributed to the fact that undocumented peoples are reticent to access vital services, such as health care, for fear of detention and deportation. ${ }^{20}$ In addition, health-care costs are a serious deterrent, since undocumented migrants are expected to pay out of pocket for all services. ${ }^{21}$ Another reason undocumented residents are unable to access health services and have higher rates of hospitalizations is the paucity of health providers who serve such populations. ${ }^{22}$ In addition, many undocumented immigrants face linguistic and cultural barriers that further deter them from accessing services. $^{23}$

Undocumented children and youth, in particular, bear the brunt of this lack of health security, since they are rarely afforded the opportunity to receive treatment for any illness, minor or major. Children born to undocumented parents receive negligible prenatal and postnatal care, suffer from higher incidences of health problems in infancy, and are
(C) Author(s), 2015. This open-access work is licensed under a Creative Commons Attribution-NonCommercial 4.0 International license.
Cette oeuvre en libre accès fait l'object d'une licence Creative Commons Attribution-NonCommercial 4.0 International. 
less likely to receive medical treatment than those born to immigrant parents with legal status. ${ }^{24}$ Although children of undocumented parents born in Canada are Canadian citizens and therefore endowed with all the rights that come with such a title, they are less likely to access health care because their parents fear that taking their child to a medical facility may expose their lack of immigration status and result in deportation. ${ }^{25}$ Additionally, youth who reside in Canada without formal legal status, similar to their parents, are unable to receive treatment or annual checkups, which are common for other children their age, and rarely visit a doctor, even in times of need. ${ }^{26}$ Given that undocumented families are encumbered with exorbitant financial costs when accessing health care, coupled with the palpable threat of detention or deportation when accessing services, undocumented youth lack meaningful health security in Canada.

\section{Employment and Financial Stressors}

For most individuals in society, financial and economic security is the direct corollary of procuring steady, wellpaid employment. This type of security is usually found within primary markets, which employ salaried professionals in the government or private sector who engage in nonmanual labour. ${ }^{27}$ Although undocumented immigrants participate in the workforce at higher rates than both legal immigrants and the general population, they are relegated to working permanently within the informal economy because they are unable to obtain employment in primary markets, since they do not have legal work authorization. ${ }^{28}$ The informal economy, as described by Portes, refers to the "sum total of income-earning activities that are unregulated by legal codes in an environment where similar activities are regulated. Informal activities are distinguished from criminal ones in that they encompass goods and services that are legal, but whose production and marketing is unregulated. ${ }^{29}$

Work within the informal economy is precarious, as there are no labour or environmental laws governing any practices, nor are there any benefits for workers, and as a result, exploitation is deeply ensconced within such industries.

Sectors with significant concentrations of undocumented workers include construction, agriculture, manufacturing, hotel, and service industries..$^{30}$ Such "under-the-table" wages are woefully insufficient for most individuals' and families' subsistence, and as a result, undocumented immigrants are the working poor, who maintain steady employment but whose wages total less than the poverty level of the host nation. ${ }^{31}$ Many undocumented youth enter the workforce to support their families and pay for education..$^{32}$ Like their parents, they are permanently relegated to low-wage jobs within the informal economy. The nature of working within the informal economy subjects adults and adolescents alike to greater health and safety risks because these settings are unregulated. ${ }^{33}$ Consequently, compromised physical health status and mental stress due to job-related risks are highly prevalent in undocumented populations. ${ }^{34}$ Although living without legal immigration status is itself implicated with significantly higher levels of stress in youth and adults, constant financial insecurity negatively affects undocumented youths' morale, sense of wellness, beliefs about the future, and sense of hope ${ }^{35}$ Youth and adolescents express a sense of general malaise when confronted with the grim reality that their only option for obtaining employment is in the informal economy and that this may remain their reality indefinitely, or at least until they procure legal status. ${ }^{36}$ Undergoing development in conditions where professional growth and related identity is severely constrained because of lack of documentation creates conditions conducive to hopelessness, depression, powerlessness, anxiety, and higher levels of stress. ${ }^{37}$ In other words, when employment and financial factors impel undocumented youth and adolescents to work in precarious jobs, and they feel there is no upward mobility because of a lack of status, their development may be truncated and their mental health negatively affected.

\section{Emotional Impact of Fear of Detention and Deportation}

\section{Social Impairment}

Social impairment refers to difficulties initiating and maintaining satisfying relationships and tends to affect functioning..$^{38}$ Such difficulties in relationships may be manifested through avoidance, irritability, and conflict with parents, siblings, or peers. 39 Undocumented youth often consciously avoid interacting with peers and initiating close friendships or relationships out of fear that others may find out and disclose their status. $4^{40}$ Such avoidance is not rooted in simple puerile insecurity or pathological complexes, but reflects youths' understanding of their social surroundings and the belief that disclosure of status would negatively impinge upon both their life and the lives of family members. ${ }^{41}$ Thus, lack of trust in relationships is more closely related to not having status and concomitant fears. This is of concern, given the fact that the ability to form and maintain stable friendships and forge romantic partnerships is typically witnessed in normally developing adolescents, and lack of trust-despite being unrelated to pathological complexes-may impede normal development in undocumented adolescents, since there are palpable disincentives to reveal personal information about oneself and form close ties with peers or romantic partners. ${ }^{42}$
(C) Author(s), 2015. This open-access work is licensed under a

Creative Commons Attribution-NonCommercial 4.0 International license.
Cette oeuvre en libre accès fait l'object d'une licence Creative Commons Attribution-NonCommercial 4.0 International. 
Many undocumented youths' patterns of conflict with their family members are borne out of a sense of exasperation, discontentment, and futility in changing their status. 43 Although adolescence is normally a period where parentchild relationships witness more intense confrontations and conflict, such strife is typically a function of the adolescent's growing cognitive and social abilities whereby their desire for greater freedoms causes friction with parents, undocumented youths' conflict with their parents are oftentimes associated with their lack of status and the ways in which immigration status itself restricts their personal freedom to obtain a driver's licence, gain legal employment, participate in extra-curricular activities, or frequent public spaces such as malls and movie theatres where security personnel and police are present, without fear or threat of detention and deportation. Such parent-child tensions often remain unresolved, as parents are unable to grant such freedoms on an individual level to their children, leaving such tensions and conflicts unresolved and an environment where frustration and futility may easily emerge.

Examining developmental patterns among undocumented youth shows atypical problems in developing and maintaining friendships and romantic partnerships, along with atypical problems in the parent-teen relationship, which typify social impairment. Although there is a relationship between social impairment and psychological disorder, these symptoms are not necessarily acute enough to warrant a diagnosis but are important stressors nonetheless. ${ }^{44}$

\section{Loneliness and Depression}

Undocumented youth often express a profound sense of loneliness, which stems from their belief that other youth simply do not understand what it means to live without immigration status and therefore feel that many of their relationships are characterized by lack of understanding and empathy. ${ }^{45}$ Consequently, many undocumented youth feel they are struggling alone. ${ }^{46}$ Such sentiments are further exacerbated by feelings of powerlessness and hopelessness, which are related to the lack of opportunity and understanding that they do not possess the agency required to alter their status. Such beliefs, thoughts, and emotions give rise to depression in undocumented youth populations. ${ }^{47}$ Furthermore, it is commonplace for such youth to yearn for privileges denied them because of their lack of status..$^{8}$ Most research in the field has chronicled how youth constantly desire a driver's licences, student visa, and work authorization. When such aspirations go unrealized, many youth become depressed that they are unable to engage in age-appropriate activities and feel left out. 49 Thus, loneliness and depression are recurrent themes in the lives of undocumented youth.

\section{Anxiety}

While living without status, many undocumented youth experience extended periods of anxiety and feel apprehensive about their unstable future. ${ }^{50}$ Incapable of predicting where they will be residing in a year (due to threat of deportation), youth experience high levels of anxiety, especially when planning education and employment. ${ }^{51}$ In particular, undocumented youth experience a variant of "persecutory anxiety," which results in an emotional state "whereby the host environment ... is experienced as hostile and persecutory" because of the threat and fear of imminent or distant deportation. ${ }^{52}$ Such anxiety is endemic to undocumented youth because they must contend daily with deportationrelated distress.

Almost all of the literature examining impacts of lack of immigration status on youth have been conducted in the United States and it is important to note that even there, such studies are few and far in between. This study seeks to investigate such impacts in Canada and investigate the ways in which adolescents are affected by their lack of immigration status. Because adolescence is a period of rapid cognitive, social, and emotional growth, in which identity is developed and consolidated, it is necessary to study whether undocumented youth exhibit atypical developmental patterns, as this would have significant mental health impacts on the family and individual unit as well as have implications for social and health policies. Further, this study specifically aims to examine the ways in which status affects stress, anxiety, loneliness, and general health security.

\section{Methods}

Qualitative designs are appropriate for exploring the lived realities of populations from their own distinct perspectives. ${ }^{3}$ As little research has been conducted in Canada on the mental well-being of undocumented youth, this study functions as a preliminary exploration of the ramifications of living in daily fear of detention and deportation. As such, a qualitative approach was adopted to accurately gauge what factors affected youths' and young adults' sense of mental well-being. It should be noted that non-status youth represent a particularly vulnerable population, and protecting confidentiality is a matter of personal safety and security. To ensure this, the researcher secured Research and Ethics Board approval at the university level and ethics approval at each of the social service organizations where recruitment took place, and all clearances were garnered with the understanding that names and addresses would not be collected at any stage of the research. For participants under 15 years of age, verbal consent was attained from parents.
(C) Author(s), 2015. This open-access work is licensed under a Creative Commons Attribution-NonCommercial 4.0 International license.
Cette oeuvre en libre accès fait l'object d'une licence Creative Commons Attribution-NonCommercial 4.0 International. 


\section{Sample}

To gain access to this population, community partnerships were forged between the researcher and three social service organizations in the Greater Toronto Area that work closely with undocumented youth. ${ }^{54}$ Although all three organizations service undocumented youth, none maintain formal statistics on services provided to this population. Since a strict randomized sample was not possible to find, a convenience sample was obtained through these three organizations. A sample of 47 undocumented youth was ultimately selected who resided in Canada without status anytime between the ages of 13-22, and were currently within the (same) age bracket of 13-22. Youth participating in the study varied in length of time they were undocumented, ranging from 11 months to 14 years. In an attempt to establish gender parity and explore whether there were any differences based on sex, 24 males and 23 females were selected (see table 1 for a summary of the sample's demographic characteristics).

\section{Recruitment}

Recruitment for this study was conducted by each of the three organizations internally, as they were privy to immigration information about their respective clients and had provided institutional ethical clearance for the study. On the basis of participant requirements set by the researcher whereby all individuals had to be 13-22 years of age and living without immigration status, each organization designated a staff member to select participants that fit these criteria. Each organization selected 15-20 individuals and provided the researcher with their contact information when the individual agreed to be part of the research and consented to being contacted by the researcher. Afterwards, the researcher contacted the participant individually and set up a time and location to conduct the interview.

\section{Procedure}

In-depth, semi-structured interviews were conducted by asking nine open-ended questions followed by questions that provided opportunities for participants to elaborate on their responses (see table 2 for the list of interview questions). For example, follow-up questions were asked when the interviewer felt the participant had not answered a question fully or when the participant raised issues that seemed relevant to the study. All interviews took place in individual sessions that ranged from one and a half to two hours in length. All interviews were digitally recorded with the permission of the participants and transcribed verbatim afterwards. The descriptive data were analyzed using a grounded theory approach. Through a method of constant comparison, recurring topics, keywords, and phrases within and across the interviews, coding categories
Table 1. Demographic characteristics of the sample

\begin{tabular}{|c|c|}
\hline Demographic variables & Number of participants \\
\hline \multicolumn{2}{|l|}{ Age } \\
\hline 13 & 1 \\
\hline 14 & 1 \\
\hline 15 & 12 \\
\hline 16 & 10 \\
\hline 17 & 13 \\
\hline 18 & 7 \\
\hline 19 & 1 \\
\hline 20 & 1 \\
\hline 21 & o \\
\hline 22 & 1 \\
\hline \multicolumn{2}{|l|}{ Gender distribution } \\
\hline Male & 24 \\
\hline Female & 23 \\
\hline \multicolumn{2}{|l|}{ Country of origin } \\
\hline Mexico & 16 \\
\hline Jamaica & 10 \\
\hline Philippines & 7 \\
\hline Sri Lanka & 5 \\
\hline Nicaragua & 4 \\
\hline Bangladesh & 2 \\
\hline Haiti & 2 \\
\hline Costa Rica & 1 \\
\hline \multicolumn{2}{|l|}{ Duration of stay in Canada } \\
\hline $0-2$ yrs & 9 \\
\hline $2-4$ yrs & 15 \\
\hline $4-6$ yrs & 19 \\
\hline $6-8 \mathrm{yrs}$ & 2 \\
\hline $8+y r s$ & 2 \\
\hline \multicolumn{2}{|l|}{ Work status } \\
\hline Working & 39 \\
\hline Not working & 8 \\
\hline \multicolumn{2}{|l|}{ Family income } \\
\hline$<10 K$ & 11 \\
\hline $10 \mathrm{~K}-19 \mathrm{~K}$ & 14 \\
\hline $20 \mathrm{~K}-29 \mathrm{~K}$ & 22 \\
\hline \multicolumn{2}{|l|}{ Education completed } \\
\hline Middle school & 47 \\
\hline High school & 4 \\
\hline \multicolumn{2}{|c|}{ English proficiency (self-reported) } \\
\hline Good & 45 \\
\hline Fair & 2 \\
\hline Poor & o \\
\hline
\end{tabular}

(C) Author(s), 2015. This open-access work is licensed under a

Creative Commons Attribution-NonCommercial 4.0 International license.
Cette oeuvre en libre accès fait l'object d'une licence Creative Commons Attribution-NonCommercial 4.0 International. 
Table 2. Interview questions

\begin{tabular}{ll}
\hline 1 & How would you describe yourself? \\
2 & What do you identify yourself as? How did you identify yourself before you moved to Canada and how would you identify yourself today? \\
3 & Does your immigration status - or lack thereof-affect you? Your family? Your community? \\
4 & What are your sources of motivation and support? (Examine familial, peer, and institutional levels.) \\
5 & What are the biggest stressors in your life? How do they make you feel? \\
6 & What could be done to alleviate the stress you feel? \\
7 & What do you immediately associate with the words detention and deportation? \\
8 & Do you think about detention or deportation daily? If so, how do you deal with the possibility of being detained or deported? \\
9 & What do you see as the biggest hurdle to gaining full immigration status? How do you tackle this issue?
\end{tabular}

and relationships among the data sources were mapped out through repeated sifting of the data. ${ }^{55}$ Subsequent stages of focused coding involved renaming and condensing codes and use of "family" or umbrella categories that brought together the underlying codes they represent. The codes and themes that emerged from the participants' narratives were analyzed by examining the participants' social location on the contextual variable of immigration status and how this location informed their experiences.

\section{Results}

Several themes were mentioned by all or almost all participants (see table 3 for prevalence of coded factors). All study participants reported experiencing emotional and psychological distress, including chronic stress, depression, loneliness, trauma, anxiety, hopelessness, and social impairment related to lack of immigration status. Although participants expressed these issues in different ways and to varying degrees, such themes were consistent across all 47 participants, irrespective of sex, age, education, ethnicity, and all other demographic variables. Distress was expressed within the participants' narratives as stemming from living in constant fear of deportation or detention and lack of individual control over the future and their own lives. Throughout the duration of the study, it was made salient that beyond the individual impacts on youth, the greatest impact of health security, or severe lack thereof, was on the family unit. Participants indicated that many family members suffered from similar symptoms and distress to those experienced by the youth in the study.

\section{Impact of Living without Status on Youth Identity}

\section{Formation and Consolidation}

Adolescence is a time of intensive social and personal development, one in which identity development and consolidation take centre stage, making it imperative to examine the effects of living without status on youth personal identity. ${ }^{56}$ In general terms, personal identity refers to an individual's mental representation of his or her own social, emotional, and cognitive characteristics and is best understood as a complex bio-psychosocial phenomenon, meaning that biological, psychological, and social/environmental factors are all implicated in identity creation and formation. 57 Undocumented youth develop within a social environment where their very presence is viewed as threatening (and thus, subject to detention and deportation), which has shown to interfere with conventional processes and mechanisms of identity formation in adolescence. Three themes were identified as negatively affecting undocumented youths' sense of identity: invisibility, consciousness of criminality, and undocumented consciousness.

\section{Invisibility}

One of the most frequent themes related to not being able to form a cohesive self-identity was that of invisibility-thoughts and feelings related to the belief that an individual's presence within the physical confines of a state is consciously ignored and erased. Invisibility impeded formulating a sense of self because participants believed that their very existence was socially and systematically invalidated, thus making it difficult to form an identity, given that societal institutions failed to even acknowledge their existence. As Participant A reported,

It's like, I don't even exist in Canada. If I don't exist then how can I be here talking to you, you know? It doesn't make sense to me ... I'm trying to figure out all this noise in my head but if I don't exist, then, does it even matter?

Another participant further elucidated,

The other day we had to do this assignment at school about what our interests are, what we want to become, what kind of person we are, all those type of stuff. Anyway, I'm doing this assignment ... and I'm thinking that it's all good to know this, but it doesn't matter for me. I can't take advantage of this knowledge [about myself]
(C) Author(s), 2015. This open-access work is licensed under a Creative Commons Attribution-NonCommercial 4.0 International license.
Cette oeuvre en libre accès fait l'object d'une licence Creative Commons Attribution-NonCommercial 4.0 International. 
Table 3. Prevalence of coded factors

\begin{tabular}{|c|c|c|}
\hline Primary category & Factors & $\begin{array}{r}\text { Number of } \\
\text { participants }\end{array}$ \\
\hline \multicolumn{3}{|l|}{ Identity formation/ } \\
\hline \multirow[t]{6}{*}{ consolidation } & & 47 \\
\hline & Invisibility & 41 \\
\hline & Consciousness of & \\
\hline & criminality & 36 \\
\hline & Undocumented & \\
\hline & consciousness & 47 \\
\hline \multirow[t]{11}{*}{ Stress and anxiety } & & 47 \\
\hline & Inability to control & \\
\hline & future & 46 \\
\hline & Fear of disclosure & \\
\hline & of immigration & \\
\hline & status & 47 \\
\hline & Inability to access & \\
\hline & vital services & 39 \\
\hline & Employment and & \\
\hline & financial stressors & 47 \\
\hline & Lack of information & 44 \\
\hline \multirow[t]{3}{*}{ Protective factors } & & 42 \\
\hline & Familial support & 38 \\
\hline & Sense of agency & 37 \\
\hline
\end{tabular}

because even after I figure out all this stuff, like what I want to do or interests or who I am-whatever that means-it's not like I'm going to get the chance to apply it. In the end, I can't get a job that represents who I am ... [because] I apparently don't exist in Canada ... it doesn't matter who I think I am or all that, the only thing in the end that really matters is if I have status or not ... and no amount of getting to know myself or filling out questionnaires during Civics class that are supposed to tell me about myself matters if you ain't got no status.

Thus, feelings of invisibility cause youth to view processes of development as being somewhat inconsequential when faced with structural and societal constraints that are the immediate corollary to living without status.

Furthermore, feeling of being made invisible is associated with social exclusion, which negatively affects youths' identity. Participant F conveys such sentiments with clarity:

My family came here [to Canada] years ago and I always hear all this talk about how this country's so multicultural and blah blah blah ... how Canada isn't, like, as racist as the U.S. That's not the Canada I live in. For seven years I've been living without status, and for seven years I feel like I don't belong ... like other people don't want me here ... that I'm not wanted. I used to feel really sad [about this] ... like an outsider in my own home ... I don't know, but sometimes I feel coming here and living without status raped me ... it raped me of my dignity, it raped me of my self-respect, it raped me of my rights ... it raped me of me.

From such vignettes, it is notable that undocumented youths' feelings of exclusion and marginalization within Canadian society impedes development of identity and leads to experiences in which their sense of identity is negated by their precarious immigration status. In other words, and as expressed by all 47 participants, identity formation and issues surrounding who they are are as individuals is directly informed by what they are in Canada: individuals made invisible who live as "second-class, maybe no class, people without rights," as stated by another participant. Thus, lack of immigration status impedes development of a coherent self-identity because of the constant precariousness of being undocumented and made invisible. This is particularly noteworthy, as feelings of invisibility are associated with distress, frustration, and depression in refugee populations, which may lead to disturbances in forming a coherent self-identity, since typical development does not include extended periods of depression and clinical distress. ${ }^{58}$ Feelings of invisibility increased with the length of time during which the individual lived in Canada without status. Those who resided without status for more than two years mentioned feelings of invisibility with greater frequency in their narratives than those who had been living without status for less than two years. However, this finding should be interpreted with caution, as feelings of invisibility may have been more frequently mentioned by participants not just as a function of duration of time living without status, but may also be due to age and awareness that is a corollary of development and more defined awareness about such issues.

\section{Consciousness of Criminality and Undocumented Consciousness}

Living within a country where the discourse about immigration, especially about immigrants without formal legal status, is often exclusionary and hostile, and creates an environment conducive to fear and insecurity. For undocumented immigrants, the very language surrounding their lives elides their presence within the host nation and is suffused with pejorative terms, such as illegal alien, parasite, wetback, and criminal, among others. Thus, growing up in such a social environment may make creating a secure sense of self-identity-one of the milestones of development in adolescence-challenging and fraught with difficulty. In particular, the "consciousness of criminality," referring to the stigma undocumented youth experience because they
(C) Author(s), 2015. This open-access work is licensed under a Creative Commons Attribution-NonCommercial 4.0 International license.
Cette oeuvre en libre accès fait l'object d'une licence Creative Commons Attribution-NonCommercial 4.0 International. 
live in Canada "illegally" and are denigrated, results in a denuded sense of self and negative feelings about identity.

This "consciousness of criminality" is disseminated most potently through media production and reproduction of undocumented individuals as criminals. These types of depictions affect undocumented youths' sense of identity because they are consistently exposed to such stories through television programs, news, articles, and other publications. Because they are portrayed as criminals, 36 of the 47 participants reported feelings of discomfort, stress and tension when asked about how their identity was affected by such media images. Participant D stated,

I hate how the media and these politicians make us to be. They always flash these crazy stories about illegal [immigrants] committing crimes and doing bad things and yeah, I know, some do, but they make us to be, like, that, we're all like that. The only time I ever see people like me on TV ... [is] when we're doing something wrong or [when] some newsperson ... is telling [viewers] how we're bad people ... and it gets to you sometimes. I know it's not true, but [it] still gets to me. It's 'cuz I know if I ever do anything, it won't be like [name omitted] did something bad, it's gonna be ... all these illegal immigrants are bad. So I feel [I] gotta be good so I don't mess it up for everyone else [who is in my situation].

Thus, when undocumented youth are forming their sense of identity, they are aware of the social milieu in which their development occurs and feel that they must conform and be the "good child" or "good citizen" in order to be accepted within society as an undocumented individual.

Further, this pressure to conform affects their identity because they are keenly aware that they are defined by their lack of immigration status before they are ever defined as an individual, which is referred to as the "undocumented consciousness." As one participant put it,

To be straight up, I don't think it matters [who I am] ... [because] they (society) don't care. When I go somewhere or do something, the first thing you need is proof of who you are ... like a health card or driver's licence. So it doesn't matter how nice I am ... if I treat people good, if I'm a good student ... people just see you as illegal if you don't have [legal immigration] papers.

Another participant also stated,

I'm not trying to say that personality and stuff and [who] you are doesn't matter at all or anything. I need to sleep at night and I wanna know that I've done right at the end of the day ... [but] when you have no status, that's more important ... it's what defines me. [Emphasis added]
From such statements, it becomes evident that media depictions and the links, no matter how subtle or explicit, between criminal and being undocumented influence youths' identities and that, ultimately, youth feel their identity is defined primarily by their lack of status, not by who they are as an individual.

\section{Stress and Anxiety}

All 47 participants reported experiencing heightened stress and anxiety related to their lack of immigration status. The stress and anxiety stemmed mainly from not being able to control their future, potential disclosure of immigration status, inability to access vital services, precarious employment and financial situations, and lack of information.

\section{Inability to Control One's Future}

All participants reported that much of their stress and anxiety could be attributed to the fact that their precarious immigration status prevents them from being able to control large parts of their lives. As Participant E stated,

Not knowing is stressing. I have a 94 average [in school] and other people [my age] are applying to university, but [I] can't count on that. I don't know if I'm even going to be in Canada next year or tomorrow. If it happens [that I get deported] then I lose everything ... No one ever plans to be deported, it just happens ... so nothing's set and no matter how well you prepare, things might not work out. It's frustrating dealing with that ... there's a lot of just throwing your hands up in the air. I don't know, sometimes it's too much and you feel tense and frustrated ... [and the] stress [of it] all hits hard.

With the immediate and future threat of detention and deportation, an individual's ability to plan and schedule activities is severely constrained and the resulting uncertainty of not knowing where you will be living and what you will be doing in the future are fertile grounds for stress and anxiety. Participant B aptly expresses this:

It seems strange, I know, to others who don't experience [living without status] but a lot of what you do, you do even when you know that everything you do might lead to nothing. You plan your month, education, job, anything ... but you know, you know in the back of your head that all that planning doesn't add up to much if you get deported ... and that's real, [deportation] could happen any moment ... and that's when you feel the panic ... when you know that you don't really know what's going to happen to you. Those are moments when I have this feeling of ... futility. I don't even know, it's so much, too much, stress having to think about [the] future.
(C) Author(s), 2015. This open-access work is licensed under a Creative Commons Attribution-NonCommercial 4.0 International license.
Cette oeuvre en libre accès fait l'object d'une licence Creative Commons Attribution-NonCommercial 4.0 International. 
The inability to control or manage the future and basic things such as country of residence, employment, and educational pursuits leads to reports of experiencing heightened levels of stress and trepidation. Because the threat of detention and deportation is endemic to undocumented populations, so too it appears is the stress that comes with uncertainty about the future.

\section{Fear of Disclosure of Immigration Status}

The fear that someone may discover an individual's lack of immigration status was mentioned by all 47 participants as one of the most significant sources of stress and anxiety, and reported as having affected all facets of their lives. Fear of disclosure was the main consideration when contemplating most life decisions, from the most mundane to the most momentous. Participant $\mathrm{G}$ explains,

The fear of getting discovered [by immigration authorities] is something you have to worry about. If I go to the grocery store ... ride the bus ... play basketball in the park, I gotta think about it before because my Mom worries a lot. She tells me to be real careful and think if it's safe to go [places]. If someone finds out or asks me for ID, it's over for all of us ... so I think about everything before I go [anywhere].

In addition, many decisions, especially about pursuing friendships and romantic relationships, are affected by this palpable fear that certain situations may leave individuals vulnerable to disclosure of immigration status. Participant L explains,

It's hard to admit it even to myself, but I look back at my relationship with my ex-boyfriend and I feel kinda bad, so guilty. I just couldn't let him in on everything in my life because [lack of status] doesn't affect only me, I have to think of my brothers and sisters and my parents ... I know I wasn't all there ... and should have told him more about my life, but I couldn't. If he knew [about my status], then he could've accidentally told someone who could've told someone and you don't know where that'll go. It's hard to have relationships and be best friends with people when you can't tell them such a big part of your life ... [because your] whole family's safety [is] on the line ... if anyone finds out.

Thus, fear of disclosure of immigration status acted as a social deterrent for the majority of participants when deciding to form or maintain close relationships with potential partners or friends. As Participant D expresses it,

The less people that know, the better. So yeah, sometimes you can't pursue [relationships] but that's how it is. It's better not to get into something than to realize [later that] it's going to get you deported because someone found out.

As such, it becomes increasingly noteworthy that fear of disclosure may lead undocumented youth to refrain from engaging in social relationships and influences all life decisions, whether it be to go to the grocery store or continue being involved with a life partner.

\section{Employment and Financial Stressors}

Undocumented youth are permanently relegated to working within the informal economy where wages and labour conditions are unregulated. They work in dangerous conditions without safety equipment or job protection, since they are not allowed to unionize. The lack of job security is stressful, as Participant $\mathrm{H}$ points out:

I need this job bad, but I don't know how long I'll have it. People [are] always getting fired ... and for three weeks, I haven't gotten paid ... I want to ask [my boss] for it but if I seem pushy, he [might] fire me. It's tiring having school and work ... and then you gotta worry about even seeing the paycheque. Keeping this job is trouble ... but not having it is worse. Everything seems like trouble these days ... I get headaches from thinking too much .... maybe from stress, who knows.

Furthermore, financial compensation in sectors employing undocumented youth is extremely low, and frequently minimum wage standards are not met. Because undocumented youth and their parents work in the informal economy, their socioeconomic status is quite poor. The vast majority of youth in the study reported family income to be less than $\$ 29,000$ a year, effectively placing them in poverty. All 47 participants reported financial problems as a major reason for their high level of stress, since there was often not enough money for food, clothes, rent, and other necessities. The financial burdens are exemplified in Participant $\mathrm{C}$ who states,

There ain't never enough money, never. It's annoying, you just get fed up with the same damn situation, over and over again. You can't even understand the stress I'm feeling all the time. No matter how many hours my parents work or we [siblings] work, it's not enough. My parents get angry and frustrated ... and can I even blame them? I'm tired of it, too.

Given the harsh reality of having to procure a precarious job with little assurance of safety or security, and inadequate compensation, financial and employment factors are prominent stressors and cause for anxiety amongst undocumented youth and their families.
(C) Author(s), 2015. This open-access work is licensed under a Creative Commons Attribution-NonCommercial 4.0 International license.
Cette oeuvre en libre accès fait l'object d'une licence Creative Commons Attribution-NonCommercial 4.0 International. 


\section{Protective Factors}

Undocumented youth in the study identified two main protective factors against the stressors associated with not having immigration status: familial support and sense of agency. Though adolescence is typically understood as a period riven with conflictual parent-child relations, 38 youth in the study reported that their families were a significant source of support. In particular, participants consistently mentioned that their families were often the only people they could openly discuss immigration and status problems with and feel safe and understood when expressing their fears and insecurities. In turn, many undocumented adolescents share a close relationship with their parents and/or siblings, and described how not having status required the family unit to be close and united in dealing with these difficulties outside the home. Most adolescents described how their families shared a close bond as a result of having to address status concerns collectively.

Another factor that facilitated a sense of well-being amongst undocumented youth was a personal sense of agency. A sense of agency is an individual's subjective understanding that she exercises some control over her life and can direct her life on the basis of her needs. Although all participants readily acknowledged feelings of helplessness and not being in control of their futures as the result of status barriers, 37 participants also mentioned experiencing a personal sense of agency and feeling they could positively affect their future by working hard, doing well in school, developing networks for work, forging healthy relationships, and working to be their "best" selves. This is particularly important, given that feelings of helplessness and lack of control over immigration status is pervasive in this population. As such, cultivating a personal sense of agency promotes hope and well-being for these adolescents' mental health.

Although much of the results emphasize that undocumented adolescents experience tremendous stressors related to not having status, most of which impede their sense of personal well-being, it is important to note that healthy relationships amongst family members act as an important support system. In addition, fostering a stronger sense of agency amongst undocumented adolescents acts as a protective factor and allows individuals to cope better with their challenges.

\section{Discussion}

The findings of this study indicate that there are significant associations between lack of health security and mental well-being and living as an undocumented youth. Results suggest that being undocumented should be viewed as a psychosocial condition characterized by stress and risk. As a result of the chronic, pervasive uncertainty and fear inherent in living without status, youth in the study exhibited symptoms of anxiety and stress associated with their lack of status. Although all the youth discussed Canada as their home in various ways, their narratives testify to feelings of social exclusion within such settings and Canadian society at large. Because undocumented youth are relegated to the margins of society as "illegals," mental health issues emerge from lack of social inclusion and the inherent stresses associated with living with the constant threat of detention and deportation.

\section{Limitations and Future Research Directions}

Several limitations of the current study need to be addressed. First, in the demographic and personal characteristics of the current sample, there is a selection bias insofar as all participants were recruited from social service and advocacy organizations, and were therefore receiving or had access to services and information. This is a particularly important sampling bias to note, as the vast majority of non-status youth do not have access to services. Consequently, future studies need to account for and creatively recruit non-status youth from non-service sector sites to gauge what the mental health outcomes are for this population where the majority of people will never access social services.

Although this study's findings demonstrate that undocumented youth exhibit symptoms of anxiety and stress, it is unclear whether they would meet diagnostic criteria for clinical disorders, as comprehensive diagnostic evaluations would have to be conducted to determine this. Further, future studies would need to compare rates of anxiety and stress amongst undocumented youth to other similar populations such as refugees or immigrants, to establish whether undocumented youth suffer from higher levels of anxiety, depression, and other mental health issues. This would require quantitative studies in this area, measuring differing rates of mental health issues on numerical scales. Also, despite the fact that this pilot study documented how long youth were living in the country without status, the results showed mixed or inconclusive findings with regard to establishing any association between duration of time living without status and mental health outcomes. However, given that experiences of pervasive stress tend to compound over time if situational stressors are not mitigated or neutralized, this is an important area of study. As such, future studies should explore whether there is an associated relationship between the amount of time an adolescent lives without status and worsening mental health outcomes. Cognizant of the fact that this is an investigational study examining mental well-being and health security in undocumented youth populations in Canada, more research needs to be
(C) Author(s), 2015. This open-access work is licensed under a

Creative Commons Attribution-NonCommercial 4.0 International license.
Cette oeuvre en libre accès fait l'object d'une licence Creative Commons Attribution-NonCommercial 4.0 International. 
conducted to replicate or repudiate this study's findings before any generalizations can be made.

\section{Policy Directions}

Exclusion and marginalization of undocumented peoples occur within a social and political context that privileges certain individuals' human rights and well-being over those of others. This type of framework creates a false dichotomy of "us" against "them," where the "other" is separated by rights and privileges that are systematically denied them. Undocumented youth and their families should not be forced to live in the shadows of fear and insecurity and should be granted formal immigration status to ensure health security.

Health policies should be devised in order to ensure that immigration status need not be a prerequisite to accessing essential services. Given the pervasive nature of the stress experienced by undocumented individuals, a Don't Ask, Don't Tell (DADT) policy should be adopted and implemented, as it has been in over 30 cities across the United States. This policy would prohibit health and essential service providers from inquiring into individuals' immigration status in order to provide them with a vital service and, in the event that providers inadvertently become aware of an individual's immigration status, they would be barred from disclosing this information to immigration authorities. The DADT policy would reduce the risk and fear of disclosure of immigration status that undocumented youth and their families associate with accessing vital services. By allaying such apprehension and fear, services would be provided on the basis of need, undocumented youth would not be excluded from care, and the result would be improved health security and mental well-being.

Faria Kamal is a fifth-year doctoral student in the School and Clinical Child Psychology Program at the University of Toronto. Her research focuses on migrants and mental health. The author may be reached at faria.kam@gmail.com.

Kyle D. Killian is a family therapist and core faculty in the Marriage and Family Therapy Program at Capella University. He has published articles and book chapters on newcomers and health, trauma and resilience, and self-care and vicarious resilience in helping professionals. The author of Interracial Couples, Intimacy \& Therapy (Columbia University Press, 2013), Dr. Killian is also a blogger at Psychology Today, and has developed measures of traumatic stress, critical thinking, cultural identity, vicarious resilience, and emotional intelligence. The author may be contacted at Kyle.Killian@capella .edu.

\section{Notes}

1 Lisa R. Fortuna, "Clinical Issues and Challenges in Treating Undocumented Immigrants," Psychiatric Times, 15 August 2013; Ilene Hyman, "Immigration and Health," Working Paper 01-05 (Ottawa: Health Canada, 2001); Laura Simich, "Hidden Meanings of Health Security: Migration Experiences and Systemic Barriers to Mental Well-Being among Undocumented Migrants in Canada," International Journal of Migration, Heath and Social Care 2, nos. 3-4 (2006): 16-27.

2 Roberto G. Gonzales, Carola Suarez-Orozco, and Maria C. Dedios-Sanguineti, "No Place to Belong: Contextualizing Concepts of Mental Health among Undocumented Immigrant Youth in the United States," American Behavioral Scientist 57, no. 8 (2013): 1174-99; Nazilla Khanlou, "Precarious Immigration Status: Exploring Impacts on Health" (paper presented at the 1oth International Metropolis Conference, Toronto, 17-21 October 2005).

3 Peter Nyers, "Access Not Fear: Non-Status Immigrants and City Services," unpublished, 2006.

4 Steffen Angenendt, "Irregular Migration as an International Problem," Research Paper No. 4 (German Institute for International and Security Affairs, 2008).

5 Carola Suarez-Orozco, Marcelo Suarez-Orozco, and Desiree B. Qin-Hilliard, The New Immigration: An Interdisciplinary Reader (New York: Routledge, 2005); Wayne A. Cornelius, "Interviewing Undocumented Immigrants: Methodological Reflections Based on Fieldwork in Mexico and the U.S.," International Migration Review 16, no. 2 (1982): 378-411.

6 Leo R. Chavez, Shadowed Lives: Undocumented Immigrants in American Society (Fort Worth, Tx: Harcourt Brace Jovanovich College, 1992).

7 Alejandro Portes, The Economic Sociology of Immigration: Essays on Networks, Ethnicity, and Entrepreneurship (New York: Russell Sage Foundation, 1998); Jeffrey S. Passel, The Size and Characteristics of the Unauthorized Migrant Population in the U.S. (Washington, DC: Pew Hispanic Center, 2006).

8 Carola Suarez-Orozco and Marcelo Suarez-Orozco, Transformations: Immigration, Family Life, and Achievement Motivation among Latino Adolescents (Stanford, CA: Stanford University Press, 1995).

9 Ibid., 9.

10 Ibid., 6.

11 Nandita Sharma, "Review of Torillas and Tomatoes: Transmigrant Mexican Harvesters in Canada," Canadian Journal of Sociology 31, no. 1 (2006): 143-4.

12 Michelle Lowry, "Creating Human Insecurity: The National Security Focus in Canada's Immigration System," Refuge 21 (2002): 28-39.

13 Ibid., 17.

14 Michael J. L. Kirby and Wilbert J. Keon, Out of the Shadow at Last: Transforming Mental Health, Mental Illness and
(C) Author(s), 2015. This open-access work is licensed under a Creative Commons Attribution-NonCommercial 4.0 International license.
Cette oeuvre en libre accès fait l'object d'une licence Creative Commons Attribution-NonCommercial 4.0 International. 
Addiction Services in Canada (Ottawa: Government of Canada, 2006).

15 Brian D. Gushulak and Douglas W. Macpherson, "Health Issues Associated with the Smuggling and Trafficking of Migrants," Journal of Immigrant Health 2, no. 2 (2000): $67-78$.

16 Laura Simich, "Status and Health Security: An Exploratory Study among Irregular Immigrants in Toronto," Canadian Journal of Public Health 98, no. 5 (2006): 369-73.

17 Jacqueline Oxman-Martinez, Jill Hanley, Lucyna Lach, Nazilla Khanlou, Swarna Weerasinghe, and Vijay Agnew, "Intersection of Canadian Policy Parameters Affecting Women with Precarious Immigration Status: A Baseline for Understanding Barriers to Health," Journal of Immigrant and Minority Health 7, no. 4 (2005): 247-58.

18 Samuel Law, Miles Hutton, and Diana Chan, "Clinical, Social, and Service Use Characteristics of Fuzhounese Undocumented Immigrant Patients," Psychiatric Services 54, no. 7 (2003): 1034-7.

19 Trine Myhrvold, "Undocumentedness, Human Rights and Nurses' Obligations: An Appeal," Discussion Paper No. 1, Oslo University College, 2004.

20 Paul Caulford and Yasmin Vali, "Providing Health Care to Medically Uninsured Immigrants and Refugees," Canadian Medical Association Journal 174 (2006): 1253-4.

21 Ibid., 26.

22 Ibid., 22.

23 Ibid., 1.

24 Ibid., 26.

25 Ibid., 26.

26 Ibid., 5 .

27 Chris R. Smith, David Knights, and Hugh Willmot, WhiteCollar Work: The Non-Manual Labour Process (New York: Macmillan, 1991).

28 Ibid., 12.

29 Portes, Economic Sociology of Immigration, 29.

30 Philip Kretsedemas and Ana Aparicio, Immigrants, Welfare Reform, and the Poverty of Policy (Westport, Ст: Praeger, 2004).

31 Ibid., 36.

32 Doreen J. Mattingly, "Working Men and Dependent Wives: Gender, Race, and the Regulation of Migration from Mexico," in Women Transforming Politics: An Alternative Reader, ed. C.J. Cohhen, K.B. Jones, and J.C. Tronto (New York: New York).

33 Ibid., 38.

34 Ibid., 17 .

35 Ibid., 8.

36 Ibid.

37 Carola Suarez-Orozco, Hirokazu Yoshikawa, Robert Teranishi, and Marcelo Suarez-Orozco, "Growing Up in the Shadows: The Developmental Implications of Unauthorized Status," Harvard Educational Review 81, no. 3 (2011): 438-72.
38 Hector R. Bird and Madelyn S. Gould, "The Use of Diagnostic Instruments and Global Measures of Functioning in Child Psychiatry Epidemiological Studies," in The Epidemiology of Child and Adolescent Psychopathology, ed. F. Verhulst and H. Koot (Oxford: Oxford University Press, 1995), 86.

39 Bridget O'shea, Matthew Hodes, Gwynneth Down, and John Bramley, "A School Based Mental Health Service for Refugee Children," Clinical Child Psychology and Psychiatry 5, no. 2 (2000): 189-201.

40 Lauren Ellis and Eric Chen, "Negotiating Identity Development among Undocumented Immigrant College Students: A Grounded Theory Study," Journal of Counselling Psychology 60, no. 2 (2013): 251-64.

41 Ibid., 46.

42 Laurence Steinberg and Amanda S. Morris, "Adolescent Development," Journal of Cognitive Education and Psychology 2, no. 1 (2001): 46.

43 Ibid., 43.

44 Adrian Angold, E. Jane Costello, Elizabeth M. Z. Farmer, Barbara J. Burns, and Alaatin Erkanli, "Impaired But Undiagnosed," Journal of the American Academy of Child and Adolescent Psychiatry 38 (1999): 129-37.

45 Ibid., 46.

46 Ibid.

47 Ibid., 43 .

48 Ibid.

49 Ibid.

50 Ibid.

51 Ibid.

52 Ibid.

53 Norman K. Denzin and Yvonna S. Lincoln, Introduction: Entering the Field of Qualitative Research (Thousand Oaks, CA: Sage Publications, 1994).

54 Two of the three organizations requested to not be identified in any published materials for concern that publicly acknowledging servicing undocumented peoples may result in the loss of federal or provincial program funding. As such, all organizational identifiers have been removed.

55 Juliet M. Corbin and Anselm Strauss, Basics of Qualitative Research (Newbury Park, CA: Sage Publications, 1998).

56 Dminitris C. Anagnostopoulos, Maria Vlassopoulos, and Helen Lazaratou, "Forced Migration, Adolescence, and Identity Formation," American Journal of Psychoanalysis 66, no. 3 (2006): 225-37.

57 Ibid., 63 .

58 Oksana Yakushko, Megan Watson, and Sarah Thompson, "Stress and Coping in the Lives of Recent Immigrants and Refugees: Considerations for Counseling," International Journal for the Advancement of Counselling 30, no. 3 (2008): 167-78.
(C) Author(s), 2015. This open-access work is licensed under a Creative Commons Attribution-NonCommercial 4.0 International license.
Cette oeuvre en libre accès fait l'object d'une licence Creative Commons Attribution-NonCommercial 4.0 International. 


\title{
Navigating Civil War through Youth Migration, Education, and Family Separation ${ }^{1}$
}

\author{
ADRIAN A. KHAN AND JENNIFER HYNDMAN
}

\section{Abstract}

Why did youth move from their trans-Himalayan villages at very young ages to attend school with the risk of prolonged family separation? An in-depth study of youth from rural trans-Himalayan villages who travelled to Kathmandu, capital of Nepal, to live and study at a (free) boarding school, funded by both national and international donors, provides a starting point to address this question. The "People's War" from 1996 to 2006 in Nepal contextualizes the study, given that the Maoist insurgency in the Himalayan hinterland aimed to recruit youth to the rebel cause. The study of youth from the trans-Himalayan region living at the boarding school as students was conducted between April and July 2014 in Kathmandu. The youth arrived at the school between the ages of four and ten years, and did not see their families for several years after their arrival, given the significant distances between their villages and the associated costs of travel. Drawing on scholarship in children's geographies, the narratives of these youth are employed to underscore their agency in these biographies of migration and better understand these difficult separations during political uncertainty and civil war.

\section{Résumé}

Qu'est-ce qui a motivé certaines jeunes personnes de quitter leurs villages trans-himalayens et de poursuivre leurs études dans le contexte d'une institution scolaire, avec le risque que cela comportait d'être séparé de leurs familles pour une période prolongée, et cela à un âge très précoce? Une étude en profondeur de jeunes personnes provenant de villages trans-himalayens ruraux, qui ont effectué le trajet jusqu'à la capitale Katmandu, afin d'y vivre et de faire leurs études à un pensionnat (gratuit) subventionné par des bénévoles nationaux ainsi qu'internationaux, constitue un point de départ pour aborder cette question. La "Guerre populaire» au Népal, qui a duré de 1996 jusqu'à 2006, fournit un contexte à l'étude, étant donné que l'insurrection maoïste dans l'arrière-pays himalayen avait pour but de recruter les jeunes à la cause des insurgés. Cette étude de jeunes personnes de la région trans-himalayenne, résidant au pensionnat en tant qu'étudiants, a été menée à Katmandu entre avril et juin 2014. Les jeunes, âgés de 4 à 10 ans à la date de leur arrivée à l'école, restaient sans voir leurs familles pendant plusieurs années après leur arrivée, en raison des distances considérables entre leurs villages et l'école, et les frais de voyage qui s'y associaient. En se basant sur les travaux universitaires en géographies des enfants, les récits de ces jeunes servent à mettre l'accent sur leur capacité d'action et d'initiative dans le contexte de ces biographies de migration, et à mieux comprendre la nature de ces séparations difficiles en période d'instabilité politique et de guerre civile.

\section{Introduction}

It was so peaceful lying in the fields for hours and stare at the hills and trees around me while the goats ate. Things changed a lot once the Maoists came. My parents were in constant fear that they would take me, so they sent me to Kathmandu to study and be safe.

$$
\text { -Wangdak, age seventeen, Lower Mustang }{ }^{2}
$$

$\mathrm{T}$ This article explores the antecedents of migration, education, and family separation in the context of civil war in Nepal from 1996 to 2006 and beyond. Maoist insurgents promised positive political and economic change
(C) Author(s), 2015. This open-access work is licensed under a Creative Commons Attribution-NonCommercial 4.0 International license.
Cette oeuvre en libre accès fait l'object d'une licence Creative Commons Attribution-NonCommercial 4.0 International. 
to many rural Himalayan families during the "People's War," ${ }^{3}$ but also aimed to recruit their children into the rebel movement to fight for this change. ${ }^{4}$ While relative poverty was also a reality for many of the households that sent children to Kathmandu, it was not the sole driver of the ruralurban migration to the capital city. Decisions to migrate were made within rural political environments ${ }^{5}$ that relied on Maoist indoctrination in educational settings. ${ }^{6}$ Protection from recruitment was a factor, but scarce economic and educational opportunities for youth also prevailed.?

The article documents stories told by relocated youth, and in so doing, extends children-centred scholarship, complementing rich and extensive research on youth in relation to the war, poverty, and distorted development of the rural trans-Himalayan hinterland, far from the Kathmandu Valley and capital city. We avoid the term displacement in this article, despite our analysis of migration as related to war, precisely because it seldom accounts for the highly intentional acts taken by families in the trans-Himalayan region to relocate one or more family members, albeit in restricted contexts of warfare and abduction.

After outlining the terminology and methodology for the article, the second section briefly reviews the extensive scholarship on conditions in the trans-Himalayan region that shaped decisions for people living there, including the conditions of civil war from 1996 to 2006, and beyond. The article also engages with the children's geographies literature and scholarship about youth in contexts of forced migration to foreground the narratives of youth interviewed for the study. Our aim is to provide a more "youth-full" account of the initial migration to Kathmandu and return to their villages after years of absence. By capturing the voices and knowledge of youth who moved to the capital, ostensibly for education, a more nuanced and inclusive knowledge can be generated. ${ }^{8}$ The body of scholarship foregrounding youth experiences and accounts of conflict, displacement, and refugee studies is relatively small, though more scholars are taking up this task. ${ }^{9}$

The choice of concepts is methodologically significant. We choose to use "youth" in the study, which is not a homogenized category, but one that is conceptualized and constructed differently across time, space, and societies, across the disparities of Global South and Global North, and within a country, like Nepal. To elaborate, "teenager" was a category created in the West in the 1950s, and later imported into Nepal through globalizing forces such as the spread of magazines and media. Some adults in Nepal consider "teenager" as a legitimate category, whereas some, predominantly from villages in the Himalayas, do not recognize a transitioning stage between childhood and adulthood. ${ }^{10}$
Shanu, drawing from the work of Liechty, ${ }^{11}$ acknowledges how media outlets such as teen magazines are geared towards youth interests and build a linkage between consumers and producers at global and local scales; this further reinforces the ways in which Global North discourses dominate the construction of childhood in Nepal. ${ }^{12}$ Hart makes a similar critique of "adolescence," acknowledging its Western roots as an "artefact of modernity," and yet he still chooses this as the best term for his edited book, Years of Conflict: Adolescence, Political Violence, and Displacement. ${ }^{13}$ Hart's book squarely addresses a discourse of fear generated by some demographers, journalists, and analysts of the "youth bulge" whereby a society, usually in the Global South or Middle East, has a large and potentially explosive segment of youth in its population, relative to other age cohorts. The assumption that youth are prone to violence and that a large youth population is potentially dangerous is problematic and engages a politics that is not our focus here, but it does draw attention to youth as a risky population. Hart also traces the links between children, youth, adolescents, and education in the civil war in Nepal in considerable detail. ${ }^{14}$

Furthermore, we select "youth" for this paper, acknowledging its range of meanings across contexts. While social and economic status and language differences between youth from the city and those from the rural Himalayan communities cannot be overlooked, we avoid creating any notion of urban youth as more "developed" or modern than their rural counterparts who have long been assumed to be the target of national development projects, the "developees." 15 In the context of Nepal, Onta-Bhatta notes that since "childhood is created, experienced and re-created continually, writing about the social construction of childhood must encompass the shifting contexts, the various actors involved, and the intertwined social, cultural and political processes." 16

Bista, drawing from the work of Snellinger, acknowledges that "amongst ethnic communities whose economic livelihoods are agriculturally based, there is no dichotomization between children and adults in which, under particular circumstances, one ceases to be a child in order to become an adult." ${ }^{17}$ Carney and Madsen explore how socialization and acculturation in Nepal influence the ways in which migrant children from rural backgrounds negotiate new roles and subject positions and identity formations within educational contexts. ${ }^{18}$ Furthermore, Childs et al. observe that for child migration from the trans-Himalayan regions of Nepal, particularly the Mustang region, "within-district migration is much more common in Mustang due to the presence of more schools and religious institutions. Nevertheless, parents in all study areas who send their children
(C) Author(s), 2015. This open-access work is licensed under a Creative Commons Attribution-NonCommercial 4.0 International license.
Cette oeuvre en libre accès fait l'object d'une licence Creative Commons Attribution-NonCommercial 4.0 International. 
to local boarding schools often envision this as a temporary solution, hoping to eventually secure a seat in a more prestigious school located outside the district or even outside Nepal ... Kathmandu is the most popular destination for external migrants, consistent with a high concentration of boarding schools and monasteries in the nation's capital."19 The youth respondents analyzed in this study illuminated how irregular and limited schooling prospects in their rural villages were a major factor in migration decisions. Of the twenty-two participants, thirteen never attended school during their time in the village. ${ }^{20}$

For students who had some schooling experiences in their villages, they were invariably put into lower grades than the ones from which they came once they arrived in Kathmandu, since they had no documentation to prove their school attendance, or citizenship documents to verify their age and identity. Many of the participants did not know their exact ages, since at the time of their birth, their age was not recorded. For example, as Poso states, "When I came to Kathmandu when I was six I was not given my birth certificate. I thought I was 16 but after returning to my village I found out that I was actually 18 " (Poso, age eighteen, Lower Dolpa). ${ }^{21}$ As a community development worker who was employed in the education sector in the Himalayan region noted, if numbers are used to depict age, they are counted as one year old when a child is born. Some villages consider the number thirteen as ominous, so it is skipped once a person reaches that age, and because of leap years in the Gregorian calendar overlapping with the Nepalese calendar system, sometimes a birthday is celebrated twice in one year. ${ }^{22}$

In addition, Clark-Kazak proposes that the concern with equating age only chronologically is that it strips age of social meanings and "overlooks the fact that chronological age is itself socially constructed-employed primarily as a 'marker' of human development in societies ordered by chronological time. In many other cultures, people do not know their chronological age."23 To approach age in a more nuanced and contextualized manner, Clark-Kazak draws on the work of multiple scholars to construct the concept of "social-age." 24 Social age ensures that "the social aspects and relationships related to age are adequately recognized and taken into account, we can employ the concept of 'social age' to indicate the socially constructed meanings applied to physical development and roles attributed to infants, children, young people, adults and elders, as well as their intra- and inter-generational relationships." 25 In transitions from "childhood" to "adulthood," Gill Valentine notes that the transitions are "complex and fluid ... these transitions are bound up with wider structures such as ... the family." Such transitions become more fraught once youth leave the family for education in Kathmandu. ${ }^{26}$ If they were "sent" by their parents, concepts of children's "choice" and decision-making are difficult to discern until they navigate their return to see their families. Nanda Shrestha contends that parents tend to be the ones who send their children away to the cities to engage with bikas (Nepali for upward social mobility, or "development"). ${ }^{27}$ Yet, in the context of the Maoist rebels' project, there was legitimate fear of youth recruitment. As Lawoti and Pahari note, "As the armed conflict progressed and the need for recruits intensified the CPN-M [Communist Party of Nepal-Maoist] increasingly took to kidnapping entire classes or schools of children," predominantly in rural areas. ${ }^{28}$ In foregrounding the words, encounters, and struggles of youth-especially the stories of Lhundup, one male youth who spoke at length about his emotional journeys alongside his travels to his village and back to Kathmandu-we aim to unsettle the more statecentric geopolitical research claims that poverty and war between a suppressive state and Maoist rebels simply caused youth relocation. ${ }^{29}$ While evidence shows that these factors did shape the context in which youth found themselves, youth are also protagonists and authors of their lives.

The particular youth represented in this study left their villages between the ages of four and ten. The meanings, age identities, and social expectations that accompany such youth vary from one society to another and over time, as the concept of "social age" above identifies. $3^{30}$ Employing the concept of youth is a decision to use a term often ignored and under-theorized by migration scholars and policy-makers. ${ }^{31}$

The study comprised three focus groups and twentytwo semi-structured interviews with youth enrolled at a boarding school in Kathmandu and those who had recently graduated from it. Interviews ranged from one hour to four hours in length, were recorded with a digital device, and then were transcribed. Three focus groups with different configurations of young people were held: one included male ${ }^{32}$ youth from the Himalayan region; another included only female youth from Himalayan villages, and the last included male youth from Himalayan and non-Himalayan backgrounds. While excerpts from a range of interviews are featured in this article, we highlight the testimony of one male respondent in particular, "Lhundup," who spoke at length and in depth about his migrations to Kathmandu and back to his village on several occasions. The lead author of this article established strong rapport with many of the participants over four prior years of volunteer work at the school, and so was well known to and trusted by research participants (see table 1 for data on gender and geographical region of participants).

A sentiment shared by many participants who migrated to Kathmandu and resided in the boarding school for
(C) Author(s), 2015. This open-access work is licensed under a

Creative Commons Attribution-NonCommercial 4.0 International license.
Cette oeuvre en libre accès fait l'object d'une licence Creative Commons Attribution-NonCommercial 4.0 International. 
Table 1. Gender and geographical region of origin among participants

\begin{tabular}{|c|c|c|c|}
\hline \multirow[b]{2}{*}{ Region } & \multirow{2}{*}{$\begin{array}{c}\text { Number of } \\
\text { participant(s) }\end{array}$} & \multicolumn{2}{|c|}{ Gender } \\
\hline & & Male & Female \\
\hline Humla & 3 & 2 & 1 \\
\hline $\begin{array}{c}\text { Mustang (Upper } \\
\text { Region) }\end{array}$ & 2 & 1 & 1 \\
\hline $\begin{array}{l}\text { Mustang (Lower } \\
\text { Region) }\end{array}$ & 2 & 2 & - \\
\hline $\begin{array}{c}\text { Dolpa (Upper } \\
\text { Region) }\end{array}$ & 4 & 2 & 2 \\
\hline $\begin{array}{c}\text { Dolpa (Lower } \\
\text { Region) }\end{array}$ & 6 & 4 & 2 \\
\hline Mugu & 1 & 1 & - \\
\hline Manang & 1 & 1 & - \\
\hline Mixed backgrounds & 2 & Humla-Jumla & $\begin{array}{c}\text { Upper Dolpa- } \\
\text { Upper } \\
\text { Mustang }\end{array}$ \\
\hline
\end{tabular}

prolonged periods was the tension between living in Kathmandu and wanting to be back in their villages. 33 At the beginning of one interview, Champo stated, "I do not want to start by sharing with the word firstly, and end with the word lastly, because my experience is more than just one beginning and one end ... Actually, sometimes there is an end before a beginning" (Champo, sixteen, Lower Dolpa). Champo's insight, similar to the rest of the participants' testimonies, reflects the fluidity of migration, villages, education, and family separation experiences. In order to gain access to and engage with youth testimonies, and to enter difficult discussions and sensitive conversations about civil war experiences, a comfortable and transparent space was created in which participants trusted they could share and also withdraw from the research at any time without repercussions. ${ }^{34}$ In this space, participants exchanged rich details about how they understood the reasons for their migration to Kathmandu, but also learned from it. For example Lhundup acknowledged,

This research project was definitely very useful. The process of working with you helped me to build my confidence with speaking and to draw attention to important details in my life. The most important thing this research has done is give me the ability to spread knowledge about Nepal and its Himalayan region's tradition, culture, past political conditions, living styles and religion. (Lhundup, nineteen, Upper Mustang)

Amrita noted,
We need more research like this that lets us express freely and feel comfortable doing so. Expressing our views is important but often when people ask us to express our views, the questions kind of already limits what you are going to say. (Amrita, sixteen, Lower Dolpa)

Holloway argues that children and youth voices "have something valuable to add to debates about their lives and we need to continue to insist on the importance of listening to them, even (perhaps especially) where their views challenge conventional academic and activist wisdom."35 Thus, the testimonies of youth help to bridge the realm of education and research by drawing upon different facets of children's lives to construct them as competent social actors within educational spaces, research spaces, and their own lived experiences. Our article expands the scholarship on children's geographies and in forced migration studies by focusing upon the lives of Himalayan youth migrating during a time of political unrest, but also by underscoring their agency, processes of identity construction and interpretation of their migration to the capital, separation from family, and education in Kathmandu.

The journeys that youth respondents undertook to get to Kathmandu span vast distances, often on foot, during a time when transportation was virtually non-existent and/ or affordable. As Stirr acknowledges, the far western parts of Nepal and the high mountains have long been neglected in infrastructural and economic development. ${ }^{36}$ This gap often resulted in long-term family separation. Shrestha, Carney and Madsen, and Basnett illuminate rural migration to cities like Kathmandu, while Childs et al. draw attention to particularities of migration from regions such as Mustang. ${ }^{37}$ Pertaining to migration in the Maoist context, Eck, Stirr, Kohrt et al., as well as Pettigrew and Adhikari illustrate the ways in which children were militarized during war in Nepal; they highlight the political ideologies and youth indoctrination around children's recruitment. ${ }^{38}$ Youth interviewed in Kathmandu draw on their recollections and on stories they have been told by family members at the time before their initial separation, upon their return to visit their villages, from their perspectives. 39 We dwell less on the technical questions, and try to elicit how and why the decisions were made by the youth affected. We probe the outcomes of their migration, education, and separation, as well as the feelings that youth harbour, and the strategies they use to manage their complicated intercultural and geographical situations. Many now struggle with the loss of their mother tongue, and familial estrangement upon leaving school and returning to their home villages for visits or to live permanently. The article analyzes youths' meanings of their migration, in some cases provided to them by their
(C) Author(s), 2015. This open-access work is licensed under a Creative Commons Attribution-NonCommercial 4.0 International license.
Cette oeuvre en libre accès fait l'object d'une licence Creative Commons Attribution-NonCommercial 4.0 International. 
parents more than a decade after reuniting with the youth, and traces the lived experience of separation and attendant feelings of rejection and abandonment. Some youth participants learned of their parents' fear that they might be recruited by the Maoists only years after they left home.

\section{On the Move}

From 1996 to 2006 and led by the Communist Party, the "People's War" was waged against the Nepali government, a royal parliamentary system. The uprising dragged on until 2006 and resulted in the deaths of thousands of Nepalese. Many youth were recruited as child soldiers by the Maoist rebels, especially in the rural trans-Himalayan region.40 Furthermore, "the year 1996 marked the launch of the 'People's War' against the authoritarian Nepali state. The rebel impetus behind the war was to fundamentally alter the 'historical relation of oppression' in the country." 41 According to Hachhethu, the political and ideological aims of the Maoist insurgency were to "overthrow the present polity based on multiparty parliamentary democracy and constitutional monarchy through armed revolution and its replacement with a new political system known as new people's democracy."42

The remoteness of the Himalayan regions played a crucial role in the Maoist insurgency. It "facilitated the possibility of initiating and developing guerrilla wars in different parts of the country by taking peasant revolution as the backbone, by centralizing activities in the rural areas and by relying on and uniting with the poor peasants." 43 Far from being a separate issue, the "People's War" was fuelled largely by poverty, unemployment, underdevelopment, exclusion, corruption, and bad governance, which largely oppressed rural populations. 44

During the Maoist insurgency the Maoists recruited children and youth as combatants. Often there was a strong element of force; media reports stated that "the Maoists have taken hostages, tortured 'scores of people' and have recruited children as combatants." 45 Testimonies from formal child soldiers featured in the work of Kohrt et al. found that children who were recruited and attempted to flee "had the poorest outcomes possibly because their support system in the armed group transformed into a threat. Children reported being hunted down by the armed group to force them back into recruitment." 46 During the conflict in Nepal, Amnesty International had "called upon the warning parties to sign a Human Rights Accord to the National Human Rights Commissions (NHRC), a mandate to monitor human rights." 47 However, Crane suggests that media discourse was skewed in favour of the government. ${ }^{8}$ Lawoti and Pahari echo this in relation to international organizations, stating that communication sources were fragmented and created a bias, perpetuating a "good"/"bad" binary between the government and the Maoists. 49

The framing of recruitment as "forced" diminishes any agency that youth may have had in making a decision to join the rebel forces. Pettigrew and Adhikari trace the story of a former child soldier, Lek Bahadur, recruited by the Maoists during the civil war. Bahadur spent many hours in the Maoists' company and was impressed by their commitment to rural Nepal. The Maoists were the only party who discussed politics with Lek Bahadur without guns. He hoped that joining them might create a better life for his family and for him. Years of war created a political space in which Nepalis craved peace. "'Forgetting fear' both acknowledged an emotional state and reflected a choice ... people like Lek Bahadur had also made a choice. After years of conflict, people desperately wanted peace and by choosing to forget they actively engaged with the peace process." 50 Despite the lack of disclosure about Lek Badur's approximate age, Tiwari notes, "Close to 100,00o rural youths failing high school examination every year have neither a job nor a school to go where they could be kept busy. These unemployed youths, 15 to 18 years in age, are joining the ranks of armed guerrillas. The Maoists, however, have problems of providing arms to these willing recruits." 51

The economic environment and lack of youth educational mobility extends part of the rationale for young people's involvement in radical movements. Zharkevich contends that the "Maoist movement in Nepal was self-consciously pedagogical, even if it was pursuing a goal opposite to that of formal schooling ... Arguably, in the context of war, and with a lack of opportunities for social mobility, a guerrilla movement can attract young people as an alternative provision for learning and a vehicle for social mobility."52 Zharkevich highlights a dimension that Tiwari ignores, namely the complex matrix of conditions-economic, political, and educational-present in the rural Himalayan regions. Poverty, civil unrest, and scarce educational opportunities created conditions ripe for recruitment by the Maoist insurgency.

\section{Education or Separation? Youth Narrate Their Migration to and from Kathmandu}

In exploring the scholarship in children's geographies, and to a lesser extent within the forced migration literature, we use the youth narratives to analyze their role in the family and in relation to their return to their village as young adults. In doing so, we destabilize tacit assumptions that families simply "sent" their children away to escape danger and poverty. Just as subaltern subjects have no place from which to speak ${ }^{53}$ and refugees are "speechless emissaries" denied a subject position, ${ }^{54}$ so too are children and youth often
(C) Author(s), 2015. This open-access work is licensed under a Creative Commons Attribution-NonCommercial 4.0 International license.
Cette oeuvre en libre accès fait l'object d'une licence Creative Commons Attribution-NonCommercial 4.0 International. 
seen merely as wards of their parents, rather than actors in their own right.55 The subfield of children's geographies emphasizes place and exploring the everyday spaces of children and youth. ${ }^{6}$ According to geographer Cindi Katz, children's geographies "encompasses notions of children as active producers of space, as geographical subjects, and as environmental agents, at the same time as it recognizes children's limited mobility." 57 Following Katz's lead, one way to expand the boundaries of research on children's geographies is by placing more emphasis upon Global South contexts and differences in the construction of children and youth across time and space, in addition to increased interdisciplinary collaboration..$^{8}$ The social dimension of time is also important in this situation, since it helps to contextualize how participants articulate emotions and understandings of the Maoist uprising and its relation to youth migration journeys away from their remote villages.

The rebel uprising and arrival of the "People's War," sometimes called the Maoist Revolution, were relevant factors for youth migration away from rural villages. Eighteen of the twenty-two participants openly referred to either direct or indirect contact with the Maoists. Relations with the Maoists were complicated: on the one hand, recruitment was an issue and potential threat, but on the other, the offer of better educational opportunities if one joined the movement also mitigated any singular assessment of the rebels.

In a rural context, Zharkevich notes that "Maoist district committee members would come to the school, speak with the director, and then go and speak to students, encourage them to form a Maoist Student Union and organize informal classes for the study of Maoist theory," with the intention of later recruiting interested students. 59 The insurgency was seen as a potential option or pathway for youth (especially in rural regions) who were limited in school, work, and other life opportunities. Zharkevich adds that "carrying books in backpacks, compulsory independent study for several hours per day, and learning the basics of Marxist social theory and propagating it to Nepali villagers were common practices among Maoist youth."6o As Eck reiterates, “The recruitment strategy focused on voluntary membership consolidated through the use of intensive indoctrination. The group's ideology was presented in mass meetings-attendance at which was largely mandatory for local villagers-which promoted the group's ideological propaganda."61 Thus propaganda and indoctrination "fuelled the 'ideology-led' Maoist rebellion, positioning schools as key battlefields in a brutal and inhuman conflict." 62

Findings from the study complement the accounts above. When Ghephel was about seven years old, he recalls an encounter with one of his friends who was returning from grazing the cows and sheep; his friend was dressed up in
Maoist clothes. Ghephel asked him why he was wearing such an outfit, and his friend told him that the Maoist army had come to his school, given it to him, and promised a good education. Ghephel's fear that he could die in the conflict prevented him from even thinking about joining the Maoists, though he did contemplate the option of education it afforded (Ghephel, age sixteen, Lower Mustang). ${ }^{63}$ Ghephel's story reveals both the educational opportunities offered by the Maoists, and how education becomes, as Pajuil states, "a site where agency and structure are in constant interplay producing contestations and conflicts,"64 but also how the Maoists were able to use rural schools as a space for recruitment without the use of violence. Education was seen by the Maoists as a key ingredient in liberating youth in the rural Himalayan villages from the autocratic rule $^{65}$ and deprivation that preceded their arrival. ${ }^{66}$

On the other hand, experiences of violence and forced recruitment also increased the spontaneity of migration decisions to Kathmandu as respondents reported. Temba recounted,

We are three siblings, one elder brother who is already married and one younger sister who is younger than me ... The Maoists came and took one child from every home in our village, most of the times boys. My parents knew I had a good chance of being taken so they sent me to Kathmandu to study. But the Maoists still took my sister. She trained for a few years and then escaped with a boy who they also captured. She married him and they came to Kathmandu for hiding. She got married when she was fourteen and had one divorce already. But as I know I think she went back to the village because she could not find proper work in Kathmandu. She doesn't contact me much out of fear that someone may track her. (Temba, age seventeen, Humla) ${ }^{67}$

Skamar recounted a similar story. When he was about four, the Maoists came to his village and his family's house. The Maoists set it on fire because his parents sent him out the back door out of fear that he might be recruited. Not having enough money for the entire family to migrate to Kathmandu, his parents first sent him to a distant relative and told him to stay there for safety and not to return. Later he travelled to Kathmandu. Skamar also mentioned his little brother, who was one year old at the time and did not leave the village; he recalls that during that period many young people migrated from his village and neighbouring regions (Skamar, age twenty, Lower Dolpa). ${ }^{68}$ Both Temba and Skamar narrate personal and familial fears of the Maoist insurgency-accentuating the importance of migration experiences as a child-specific phenomenon.

The testimony of Lhundup, a respondent in this study and graduate of the school, provided the most detailed
(C) Author(s), 2015. This open-access work is licensed under a Creative Commons Attribution-NonCommercial 4.0 International license.
Cette oeuvre en libre accès fait l'object d'une licence Creative Commons Attribution-NonCommercial 4.0 International. 
and instructive responses. In an interview, he remembers his father telling him at the time (2001) that he was going to take him to Kathmandu where he would get the chance to study in a boarding school. Lhundup was excited to see Kathmandu, but did not fully realize that boarding school would result in long-term family separation. A major tension many participants experienced from staying in a boarding school related to cultural integration. Since all students came from different Himalayan regions, they spoke regionally specific dialects of Tibetan and/or Nepali. In learning a common language at the school, seventeen participants acknowledged that they have lost the ability to communicate in their village dialect. They can communicate only in the Nepalese and English mediums used in Kathmandu. Thus as time passed and Lhundup began to lose his village dialect, he felt that he was placed in school because his family no longer cared for him.

Nevertheless, Lhundup, who migrated to Kathmandu in 2003 , had the rare opportunity over eleven years to visit his village twice in Upper Mustang. On his first return visit in 2007 , he was excited to visit his family. Upon arrival, however, he found that his father, an elder brother, and an elder sister were ambivalent towards him. A week later, his father told him that he had to return to Kathmandu since they (Lhundup's father, elder brother, and elder sister) were migrating to Lower Mustang for work. Lhundup felt agitated that he had spent so much time preparing to spend at least two months with his family, and they told him he had to leave after a week. After his return to Kathmandu his agitation turned into deep frustration, and eventually feelings of abandonment. In 2014, seven years later, after completing his secondary level of studies (class ten), Lhundup had the opportunity to visit his family once again. He was deeply conflicted about the visit and contemplated whether he really wanted to go. Eventually he did decide to visit. $\mathrm{He}$ recalled,

When I was returning I often had to use a tractor. Just think of how physically hard it is, with the dust and wind, for about six hours at a time for two days without sitting. In these moments I was really regretting going back and vowed that I never will. I was with some other villagers on the tractor, and when I told them my emotions, they said that tourists were coming to our village by spending lots of money, so I should be happy to have the opportunity to live there. But I was thinking, even I would like to go to other countries to visit, same like the tourist, but there is a difference with visiting a place and wanting to live there permanently. However, when I saw the [very poor] condition of my village and my family, my thoughts completely changed and it made me want to come back again. That day I came to a realization ... Whatever the situation in life, good or bad, events will happen that you cannot control. Whatever the outcome, it helps you to learn. I don't know what I will do in my future but I will try my best to keep and expand my relations with my village and family. (Lhundup, age nineteen, Upper Mustang) ${ }^{69}$

Lhundup's self-reflection and dialogue with his estranged family changed his feelings of abandonment to feelings of acceptance. Specifically, Lhundup came to terms with his family's apparent indifference toward him during his prior visit in 2007. Not until his visit in 2014 did Lhundup come to understand that his family wanted him to be safe from the Maoist insurgency and how the threat of rebel recruitment affected his life course. During his trip home in 2014, his father began to cry when Lhundup told him that putting the boy in a boarding school in 2001 had made him feel rejected from the family. His father told him then that the Maoists insisted that one child join the Maoist movement from each household, so out of fear that Lhundup would be recruited, his father decided that schooling in Kathmandu, far away from Upper Mustang, was the safest option.

His father had also made the difficult decision to send Lhundup's two younger sisters and two elder brothers to a school in India. Lhundup's youngest brother was also sent to a school in Lower Mustang to avoid recruitment. Only Lhundup's eldest sister and brother remained in Mustang, as they were much older than the other siblings and therefore were not at risk of being recruited by the Maoists. As Lhundup recalled, his father told him that each experience of placing his children in various boarding schools was hard and emotional. He apologized to Lhundup for the lack of emotions expressed when his son visited in 2007, and acknowledged that despite the official end of the Maoist revolution in 2006, there were still some small-scale Maoist activities throughout the Himalayas. His father sent him back to school in Kathmandu with the intention of protecting him, but without Lhundup understanding this. Despite his efforts, Lhundup still feels somewhat like an outsider in his home village because he cannot fluently speak his mother tongue, but he has been trying to relearn his village dialect. Furthermore, Lhundup is creating new spaces for cultural exchange by working with an international NGO to facilitate communication and bridging programs between villages in Mustang (and neighbouring Himalayan villages) with Himalayan youth living in Kathmandu and Pokhara.

Lhundup's efforts to facilitate community development projects predominantly in education and communication illustrate Ager and Strang's concepts of social bonds and social bridges. ${ }^{70}$ According to the authors, social bonds occur between and among members of families and coethnic, co-national, co-religious groups. Those who belong
(C) Author(s), 2015. This open-access work is licensed under a Creative Commons Attribution-NonCommercial 4.0 International license.
Cette oeuvre en libre accès fait l'object d'une licence Creative Commons Attribution-NonCommercial 4.0 International. 
to an ethnic enclave, for example, and share cultural practices and language would maintain social bonds. ${ }^{71}$ Those from Mustang with whom Lhundup works in Kathmandu and Pokhara share social bonds. Social bridges, in contrast, connect one distinct cultural or linguistic community with another, or with a host/dominant community. This represents a higher degree of social integration, which can facilitate wider community participation by all members and potentially better educational, employment, and economic opportunities..$^{2}$

Lhundup intends to use his networks and knowledge from boarding school in the capital-to create social bridges among different Himalayan groups, but also between these villages and the international non-governmental organizations working out of Kathmandu. For example, Lhundup is assisting with a pilot program in which Himalayan students use drama and digital media at non-Himalayan schools to address migration, gender discrimination, the acquisition of citizenship, and construction of identity. The program will run in partnership with local multiple NGOs and Tribuhvan University (the national university of Nepal). From Shrestha's perspective, the promise of bikas ${ }^{73}$ is both realized and unsettled by the experiences of the respondents in this study who are now much better educated than their other family members, but also alienated from them through years of separation 74

Almost all respondents interviewed experienced cultural dislocation from their home villages upon return, especially due to the loss of their mother tongue. Youth balance their feelings of abandonment and rejection with knowledge of their parents' fears about their recruitment and safety. Whether most youth will return to their Himalayan villages upon graduation remains an open question, despite relative peace in Nepal but also in the context of the recent earthquake. ${ }^{75}$

\section{Conclusion}

The meanings that Himalayan youth attach to their migration to the capital, separation from family, and education in Kathmandu are multiple and contested over time and across their own youthful lifespans. While youth recollect and understand that their families wanted to protect them from rebel recruitment during the period of the "People's War," they also experienced strong feelings of rejection, disappointment, and abandonment in some cases. The findings presented here have outlined some of the negative social outcomes and emotional turmoil recounted by youth affected by their relocation in the name of their "protection."

Youth should not simply be second-guessed or spoken for when they can be consulted or engaged in dialogue about major decisions affecting them. While parents may feel it is their role to shelter their dependents by taking action to protect them, academics have no reason to "voice over" youth accounts of their situation or assume that abrupt, if intentional relocation is different from displacement generated by civil war. Youth protagonists produce spaces for different kinds of knowledge that can complement more conventional research on conflict, displacement, and migration created at the scale of the state or the global economy.

Adrian A. Khan is a PhD student in geography at the University of Toronto, where he is also affiliated with the Centre for Diaspora and Transnational Studies and the Centre for Asian Studies. He completed his MA in Development Studies at York University, based on research with youth from the trans-Himalayan region of Nepal. He has spent many years as a volunteer and teacher with youth at schools in the Kathmandu Valley. The author may be contacted at adriankhan314@gmail.com.

Jennifer Hyndman is professor in social science and geography at York University, Toronto, where she is also affiliated with the Centre for Refugee Studies. Her research focuses on the geopolitics of forced migration in and from conflict zones and refugee camps to resettlement policy and outcomes in North America. She is the author of Dual Disasters: Humanitarian Aid after the 2004 Tsunami (2011), Managing Displacement: Refugees and the Politics of Humanitarianism (2000), and co-editor, Sites of Violence: Gender and Conflict Zones (2004). The author may be contacted at jhyndman@yorku.ca.

\section{Notes}

1 The authors would like to thank anonymous reviewers for their constructive comments and suggestions, as well as Terence Rudolph for his insights and assistance on the article.

2 Wangdak, personal interview, 2014.

3 Y. Basnett, "From Politicization of Grievances to Political Violence: An Analysis of the Maoist Movement in Nepal," London School of Economics (LSE) 78, no. 78 (2009): 1-33.

4 K.C. Tiwari, "Maoist Insurgency in Nepal: Internal Dimensions," South Asia Analysis Group 187, no. 1 (2001): 1-8.

5 J. Pettigrew and K. Adhikari, "Fear and Everyday Life in Rural Nepal," Dialectical Anthropology 33, nos. 3-4 (2009): 421.

6 B.A. Kohrt, J.D. Jordans, E. Perera, R. Karki, S. Koirala, and N. Upadhaya, "Social Ecology of Child Soldiers: Child, Family, and Community Determinants of Mental Health, Psychosocial Well-being, and Reintegration in Nepal," Transcultural Psychiatry 47, no. 5 (2010): 743.
(C) Author(s), 2015. This open-access work is licensed under a Creative Commons Attribution-NonCommercial 4.0 International license.
Cette oeuvre en libre accès fait l'object d'une licence Creative Commons Attribution-NonCommercial 4.0 International. 
7 See M. Lawoti and A.K. Pahari, The Maoist Insurgency in Nepal: Revolution in the Twenty-First Century (New York: Routledge, 2010).

8 D. Haraway, "Situated Knowledges," in Simians, Cyborgs, and Women: The Reinvention of Nature, 183-203 (New York: Routledge, 1991).

9 See, for example, J. Hart, "Introduction," in Years of Conflict: Adolescence, Political Violence and Displacement, ed. J. Hart, 1-22 (New York: Berghahn Books, 2008); D. Chatty, "Introduction: Deterritorialized Youth: Sahrawi and Afghan Refugees at the Margins of the Middle East," in Deterritorialized Youth: Sahrawi and Afghan Refugees at the Margins of the Middle East, ed. D. Chatty, 1-34 (New York: Berghahn Books, 2010); C.R. Clark-Kazak, Recounting Migration: Political Narratives of Congolese Young People in Uganda (Montreal and Kingston: McGillQueen's University Press, 2011).

10 N. Ansell, Children, Youth, and Development (New York: Routledge, 2005), 85.

11 See M. Liechty, Out Here in Kathmandu: Modernity on the Global Periphery (Kathmandu: Martin Chautari, 2010).

12 B.M. Shahu, review of Out Here in Kathmandu: Modernity on the Global Periphery, by Mark Lichechty, Dhaulagiri Journal of Sociology and Anthropology 6 (2012): 143-52.

13 Hart, "Introduction," 4.

14 J. Hart, "Conflict in Nepal and Its Impact on Children," Refugee Studies Centre, 2001, http://www.rsc.ox.ac.uk/ files/publications/other/dp-children-armed-conflictnepal.pdf.

15 See, for example, T. Jakimow, "Spoiling the Situation: Reflections on the Development and Research Field," Development in Practice 23, no. 1 (2013): 21-32; Stacy Leigh Pigg, "Inventing Social Categories through Place: Social Representations and Development in Nepal," Comparative Studies in Society and History 34, no. 3 (1992): 491-513.

16 L. Onta-Bhatta, "Childhood Constructed, Childhood Lived: Law and Social History in Nepal," Studies in Nepali History and Society 6, no. 2 (2001): 232.

17 A. Snellinger, "Shaping a Livable Present and Future: A Review of Youth Studies in Nepal," European Bulletin of Himalayan Research (EBHR) 42 (2013): 75.

18 S. Carney and U.A. Madsen, "A Place of One's Own: Schooling and the Formation of Identities in Modern Nepal," in Nation-Building, Identity and Citizenship Education (Dordrecht: Springer, 2009), 171.

19 G. Childs, S. Craig, C.M. Beall, and B. Basnyat, "Depopulating the Himalayan Highlands: Education and Outmigration from Ethnically Tibetan Communities of Nepa," Mountain Research and Development 34, no. 2 (2014): 85-94.

20 One student attended school for a month before deciding he did not like it and left. One student was expelled in preschool for not attending classes regularly. Three students attended once to twice a week until they migrated to Kathmandu. Four students did have "regular" schooling experiences (attended a minimum of four of six school days per week). Of those four students, the first attended two years of primary schooling (class one and class two) before he migrated from Lower Mustang; the second student from Upper Dolpa attended a boarding school in the headquarters of Dolpa (Dunai) for three years (primary class one to three); the third attended government-funded school for four years (primary class one to four) before she migrated from Upper Mustang; and the fourth student attended school for five years (primary class one to five) before he migrated from Lower Mugu.

21 Poso, personal interview, 2014.

22 Personal communication, 5 June 2014.

23 C. Clark-Kazak, "Towards a Working Definition and Application of Social Age in International Development Studies," Journal of Development Studies 45, no. 8 (2009): $1-18$.

24 Ibid.; see G. Elder, "Age Differentiation and the Life Course," Annual Review of Sociology 1 (1975): 165-90; H. Wulff, "Introducing Youth Culture in Its Own Right: The State of the Art and New Possibilities," in Youth Cultures: A Cross-cultural Perspective, ed. V. Amit-Talia and H. Wulff, 1-16 (London: Routledge, 1995); A. James, C. Jenks, and A. Prout, Theorizing Childhood (Cambridge: Polity, 1998); N. Lesko, Act Your Age! A Cultural Construction of Adolescence (London: Routledge, 2001).

25 Ibid.

26 G. Valentine, "Boundary Crossings: Transitions from Childhood to Adulthood," Children's Geographies 1, no. 1 (2003): 37-52.

27 N. Shrestha, "Becoming a Development Category," in Development: A Cultural Study Reader, ed. Susanne Schech and Jane Haggis, 103-14 (Oxford: Blackwell Publishers, 1995).

28 Lawoti and Pahari, "Maoist Insurgency in Nepal."

29 I. Zharkevich, "Learning in a Guerrilla Community of Practice: Literacy Practice, Situated Learning, and Youth in Nepal's Maoist Movement (1996-2006)," Digital Himalaya 42, no. 1 (2013): 104-32.

30 Clark-Kazak, "Towards a Working Definition and Application of Social Age."

31 O. Bakewell, "Research beyond the Categories: The Importance of Policy Irrelevant Research into Forced Migration," Journal of Refugee Studies 21, no. 4 (2008): 432-53.

32 A shortcoming of using "youth" as an organizing concept is that the English language does not have genderappropriate adjectives to qualify youth, so one must use biological designations of "male" and "female" instead.

33 J. Hyndman, "The Field as Here and Now, Not There and Then," Geographical Review 91, nos. 1-2 (2001): 262-72. 34 Ibid.

35 L.S. Holloway, "Changing Children's Geographies," Children's Geographies 12, no. 4 (2014): 382.
(C) Author(s), 2015. This open-access work is licensed under a Creative Commons Attribution-NonCommercial 4.0 International license.
Cette oeuvre en libre accès fait l'object d'une licence Creative Commons Attribution-NonCommercial 4.0 International. 
36 A. Stirr, "Changing the Sound of Nationalism in Nepal: Deudā Songs and the Far Western Region," South Asian Popular Culture 10, no. 3 (2012): 274.

37 See Shrestha, "Becoming a Development Category"; Carney and Madsen, "Place of One's Own"; Basnett, "From Politicization of Grievances to Political Violence"; Childs et al., "Depopulating the Himalayan Highlands."

38 K. Eck, "Coercion in Rebel Recruitment," Security Studies 23 (2014): 364-98; Stirr, "Changing the Sound of Nationalism in Nepal"; Kohrt et al., "Social Ecology of Child Soldiers"; Pettigrew and Adhikari, "Fear and Everyday Life in Rural Nepal."

39 Methodologically, neither the youth nor their families could be interviewed at or near the time this decision to migrate was made, since political tensions in relation the drafting of Nepal's constitution during the time of research restricted travel to trans-Himalayan regions.

40 Lawoti and Pahari, "Maoist Insurgency in Nepal," 3.

41 Basnett, "From Politicization of Grievances," 4.

42 K. Hachhethu, "Maoist Insurgency in Nepal: An Overview," in The Naxal Challenge: Causes, Linkages and Policy Option, ed. P.V. Ramana, 136-52 (New Delhi: Darling Kindersley (India) Pearson Education, 2008).

43 Ibid., 138.

44 Ibid., 139.

45 S.D. Crane, The Maoist Insurgency in Nepal: 1996-2001 (Carlisle: U.S. Army war College Strategic Studies Institute, 2002), 1-29.

46 Kohrt et al., "Social Ecology of Child Soldiers," 743.

47 Lawoti and Pahari, "Maoist Insurgency in Nepal," 230.

48 Crane, Maoist Insurgency in Nepal.

49 Lawoti, and Pahari, "Maoist Insurgency in Nepal," 218.

50 Pettigrew and Adhikari, "Fear and Everyday Life in Rural Nepal," 421.

51 Tiwari, "Maoist Insurgency in Nepal," 4.

52 Zharkevich, "Learning in a Guerrilla Community of Practice," 104-32.

53 G.C. Spivak, "Can the Subaltern Speak?," in Marxism and the Interpretation of Culture, ed. Nelson and Grossberg, 66-111 (Urbana: University of Illinois Press, 1988).

54 L. Malkki, "Speechless Emissaries: Refugees, Humanitarianism, and Dehistoricization," Cultural Anthropology 11, no. 3 (1996): 377-404.

55 J. Boyden, "Preface."

56 See, for example, S.L. Holloway and G. Valentine, "Children's Geographies and the New Social Studies of Childhood," in Children's Geographies: Playing, Living, Learning, ed. S.L. Holloway and G. Valentine, 1-26 (New York: Routledge, 2000); S.L. Holloway and H. Pimlott-Wilson, "Geographies of Children, Youth and Families: Defining
Achievements, Debating the Agenda," in Geographies of Children Youth and Families: An International Perspective, ed. L. Holt, 9-24 (Florence, KY: Routledge, 2011); N. Maine, "Refugee Youth Brokers Guiding Resettlement in Canada (MA thesis, York University, 2015).

57 C. Katz, "Children," in Dictionary of Human Geography, 5th ed., ed. D. Gregory, R. Johnston, G. Pratt, M. Watts, and S. Whatmore (Hoboken, NJ: Wiley-Blackwell, 2009), 8o-1.

58 Holloway, "Changing Children's Geographies," 386.

59 Zharkevich, "Learning in a Guerrilla Community," 114.

60 Ibid., 106.

61 See J. Becker, "Child Recruitment in Burma, Sri Lanka, and Nepal," in Child Soldiers in the Age of Fractured States, ed. Scott Gates and Simon Reich (Pittsburgh: University of Pittsburgh Press, 2009), 64; K. Eck, "Recruiting Rebels: Indoctrination and Political Education in Nepal," in The Maoist Insurgency in Nepal: Revolution in the 21st Century, ed. Mahendra Lawoti and Anup Pahari, 33-52 (London: Routledge, 2010).

62 Eck, "Coercion in Rebel Recruitment," 386.

63 Ghephel, personal interview, 2014.

64 M.N. Parajuli, "Schooling: The Way People See It," Journal of Education and Research 1 (2008): 31-40.

65 For more details on different Maoist political shifts within the civil war, see A. Adhikari, B. Gautam, S. Pudasaini, and B. Sharma, Impunity and Political Accountability in Nepal (Kathmandu: Asian Foundation, 2014). 1-120.

66 Hart, "Conflict in Nepal and Its Impact on Children."

67 Temba, personal interview, 2014.

68 Skamar, personal Interview, 2014.

69 Lhundup, personal Interview, 2014.

70 A. Ager and A. Strang, "Understanding Integration: A Conceptual Framework," Journal of Refugee Studies 21, no. 2 (2008): 166-91.

71 Ibid., 178.

72 Ibid.

73 In relation to (social) mobility, development, agency, and gender, see J. Brunson, "'Scooty Girls': Mobility and Intimacy at the Margins of Kathmandu," Ethnos 79, no. 5 (2014): 610-29.

74 Shrestha, "Becoming a Development Category."

75 The devastating earthquake in April 2015 has shaped some of the youths' aspirations to return to their villages, since the homes they were residing in, in Kathmandu, were severely damaged. If housing alternatives cannot be arranged in the city, some youth may return to their rural villages. The first author returned to Kathmandu in June to July 2015; this observation is based on several personal communications.
(C) Author(s), 2015. This open-access work is licensed under a Creative Commons Attribution-NonCommercial 4.0 International license.
Cette oeuvre en libre accès fait l'object d'une licence Creative Commons Attribution-NonCommercial 4.0 International. 


\title{
Leaving Care: Unaccompanied Asylum- Seeking Young Afghans Facing Return
}

\author{
KIM ROBINSON AND LUCY WILLIAMS ${ }^{1}$
}

\begin{abstract}
Unaccompanied asylum-seeking children in the United Kingdom approach adulthood knowing that they will be encouraged or even forced to return to their countries of birth. Drawing on a project that promoted voluntary return to Afghanistan, we use interviews with twelve young people, professionals working in the Home Office and in education, local authorities, and voluntary-sector agencies to describe a complex area of immigration policy. We show how the state's obligations as "corporate parent" clash with increasingly punitive migration controls and with growing political scrutiny of public spending. We propose education as a way to prepare young people for futures as global citizens in either country of settlement or of origin.
\end{abstract}

\section{Résumé}

Les enfants non accompagnés demandeurs d'asile au Royaume-Uni évoluent vers l'âge adulte sachant qu'ils vont être incités ou même forcés à retourner à leurs pays d'origine. En nous basant sur un projet qui encourageait le retour volontairte à l'Afghanistan, et à l'aide d'entrevues avec douze jeunes personnes, ainsi que des professionnels du ministère de lintérieur du Royaume-Uni (Home Office), des professionnels de l'éducation, des autorités locales, et des agences du secteur bénévole, nous dressons le portrait d'un domaine complexe de la politique en matière d'immigration. Nous montrons comment les devoirs de l'État dans son rôle de "parent institutionnel» se heurtent à des restrictions de plus en plus sévères sur la migration et à une attention politique intensifiée portée sur les dépenses publiques. Nous proposons l'éducation comme moyen de préparer les jeunes pour un avenir en tant que citoyens $d u$ monde, que ce soit dans les pays d'installation ou d'origine.

\section{Introduction and Context}

I n the United Kingdom, local authorities (LA), which include ports of arrival or asylum-screening centres, are responsible for the care of unaccompanied asylumseeking children (UASC) arriving in their area. Kent County Council (ксC), in the southeast corner of the United Kingdom, covers the Port of Dover, so is responsible for a relatively large percentage of the United Kingdom's asylumseeking children. The strategy document for Kent 2015-16 estimated that by March 2015, KCC would be caring for 365 UASC, representing 20 per cent of the overall care population. ${ }^{2}$ The increase in numbers of applications during the summer of 2015, however, has resulted in KCC now caring for over 720 unaccompanied children and having to open two new residential units to support new arrivals. ${ }^{3}$ State support for children in care in the United Kingdom can continue into adulthood, and the Children (Leaving Care) Act 2000 (CLCA) and the Children and Family Act (2014) protect careleavers. These young people can become classified as Appeal Rights Exhausted Care Leavers (ARECL) after reaching eighteen if their application to extend their temporary leave to remain in the United Kingdom (and subsequent appeals) fail. At this stage they risk detention and enforced return and, if a formal human rights assessment determines they have no further right to support in the United Kingdom, they can lose accommodation and support. For these young people, their status as adults refused protection trumps their claims as care-leavers and they face destitution, detention, and enforced return. Many are unwilling to return voluntarily and, even after their refugee cases have failed, actively
(C) Author(s), 2015. This open-access work is licensed under a

Creative Commons Attribution-NonCommercial 4.0 International license.
Cette oeuvre en libre accès fait l'object d'une licence Creative Commons Attribution-NonCommercial 4.0 International. 
seek fresh evidence and other means to prolong their stay in the United Kingdom. A significant proportion of UASC supported by KCC are from Afghanistan, a dangerous country undergoing political, social, and economic transition but one the UK government considers safe enough for migrants whose refugee or humanitarian claims have failed. This is despite evidence from the International Organisation for Migration (IOM) and others 4 and the widely reported comments of the Afghan minister for refugees and repatriation, Hussain Alami Balkhi, who (cited by the Home Office themselves) 5 stated a desire to renegotiate memorandums of understanding on returns with European countries to reflect the deterioration of security in Afghanistan.

The UAsC population in Kent, as in the rest of the United Kingdom, includes girls and young women, but they are far fewer than boys and young men. Girls are almost always placed in foster care, unlike boys who are fostered only if found to be under sixteen. Girls are also less likely to be returned. For reasons of political and professional sensitivity, data on UASC are hard to access, and published data do not disaggregate ARECL numbers from the general data on people supported under adult support provisions or returned to Afghanistan. There is a sharp demarcation between the treatment of asylum-seekers determined as either over or under eighteen and they have access to very different services. ${ }^{6}$ The abrupt change in immigration category from child to adult also means that it is difficult if not impossible to follow the progress of care-leavers into the adult system.

The United Kingdom's emphasis on return as a durable solution for UASC reaching adulthood is in line with Europe-wide policy, but forced return of young people remains unpalatable to the public and thus problematic for policy-makers. Return, or repatriation, is one of the UNHCR "durable solutions" to refugee movements, emphasizing voluntary movement and a return "home."7 For many young people, however, return to countries of birth does not equate to return to a "home," as many feel that their home is now their country of asylum. ${ }^{8}$ Returnees may have retained few ties, and family members may have been lost or killed, and the empirical evidence noted by Lemberg-Pedersen highlights "that family tracing in Afghanistan is all but impossible."9 Other young people will have been born outside Afghanistan in refugee camps in Iran or Pakistan. In addition, returnees may be mistrusted and alienated, ${ }^{10}$ and this further prejudices the futures of young people lacking valuable local connections and skills. Nevertheless, EU governments including the United Kingdom insist that return is the best option for these young people as, being judged without grounds for protection, they have been found ineligible to remain in the countries where they have grown up.
Returning young Afghans to Afghanistan was also seen by some of our interviewees to have a symbolic significance for the United Kingdom, as it demonstrates the government's power to effect repatriation. In the context the United Kingdom's military involvement in Afghanistan this was seen as important by some.

This article draws on an evaluation of a return initiative carried out by the authors ${ }^{11}$ that targeted over 100 ARECL. The Positive Futures Project intended to encourage ARECL young Afghans to volunteer for AVR by giving them a return package enhanced with extra training and skills that would be useful once back in Afghanistan. The project was designed by a partnership that included representatives from the LA, the Home Office Assisted Voluntary Return team, the Immigration, Compliance and Enforcement (ICE) team, as well as voluntary sector agencies and a local Further Education college. Project funding was through the Return and Reintegration Fund (RRF). Ultimately it was unsuccessful, as none of the targeted young people agreed to return and take up the training offered, but the project raises fundamental issues for projects encouraging return as a "durable solution" for former UAsc. It questions how UASC are educated and supported, how their connections to countries of origin are managed, how immigration cases should be handled, and most importantly how the needs of young people-for safety, belonging, and secure futurescan be assured. We argue that the marked unwillingness of this small group of young people to engage with efforts to encourage their return has important national and international implications. Service providers responsible for the care of UASC and policy-makers seeking durable solutions for young migrants without secure immigration status need to rethink their treatment of this vulnerable group.

\section{Legal Frameworks and Asylum Decision-making in the United Kingdom}

The processes by which young people are refused asylum and made ineligible for leaving care provisions have been well documented, ${ }^{12}$ and the Office of the Children's Commissioner's recent report explicitly examines two areas of problematic policy: the representation of UASC cases and their transition into adulthood. ${ }^{13}$ Warren and York reviewed the cases of twenty young people refused asylum and concluded that legal representation was often ineffective and inadequate. ${ }^{14}$ Gladwell and Elwyn summarize the issues facing unaccompanied asylum seeking Afghan children in the United Kingdom, ${ }^{15}$ and they identify the discretion in the system (to withdraw or continue support for example) and the specific issues affecting young people considered Appeal Rights Exhausted (ARE). These issues include their increasing vulnerability as support is cut, as
(C) Author(s), 2015. This open-access work is licensed under a Creative Commons Attribution-NonCommercial 4.0 International license.
Cette oeuvre en libre accès fait l'object d'une licence Creative Commons Attribution-NonCommercial 4.0 International. 
well as problems with age determination. The age of a child as determined on arrival will determine the services to which he or she is entitled and, ultimately, the date when he or she will become subject to removal. ${ }^{16}$ Appeals against removal can be based on ongoing legal judgements, such as the KA ruling in July 2012, ${ }^{17}$ which found a systemic breach of the duty to endeavour to trace parents. Such legal challenges raise new grounds for appeal, and "fresh claims" can always be submitted if there is a material change in a person's case, such as evidence from country of origin or changes in personal circumstance. For example, the safety of chartered removal flights to Afghanistan is being currently challenged..$^{18}$ Such disputes, shared and discussed among young people on social media, raise their hopes for the reassessment of cases. However, the increasing limitations on access to legal aid under the Legal Aid, Sentencing and Punishment of Offenders Act 2012 (LASPO), means that getting representation to restart cases and for judicial review has become increasingly difficult. In addition, changes to immigration rules in relation to article 8 of the ECHR-the Right of Private and Family Life-means that even starting a family in the United Kingdom may not be sufficient to prevent removal.

\section{Voluntary Return Schemes}

The UK government, in line with most receiving countries, emphasizes voluntary return schemes, and these, including AVR, which provides some material support for reintegration, are intended to allow migrants to return with some dignity. AVR schemes include an element of cash support as well as further support offered in-kind, in-country. This second element is intended to promote reintegration and a "sustainable return" that will discourage returnees from simply moving on to another country. "Pay-to-go" schemes such as AVR are run all over the world and are controversial to the extent that their "voluntary" nature can be disputed in cases in which migrants would prefer to stay but have little realistic alternative to return. ${ }^{19}$ The UK Home Office representatives we interviewed for the evaluation were categorical that the "voluntary" nature of its voluntary return programs is paramount, yet others of our informants saw voluntary return as a "least-worst" option for many migrants.

At the time of this project, AVR schemes in the United Kingdom were provided by Choices, a program run by the Refugee Action charity. Choices, whose services are closing on 31 December 2015, had a long record of providing impartial support for migrants considering return and had run services funded by the Home Office. Choices processed applications, provided pre-decision counselling and outreach schemes, and informed and assisted migrants considering return. They did not operate to targets, and their remit has always been to support decision-making rather to advocate any course of action. The successor to Choices as provider of voluntary return services has not yet been announced but is unlikely to be as independent or as supportive of its clients. AVR in the United Kingdom is no longer available to people in detention, and its absence again ratchets up the pressure on people facing detention, destitution, and deportation. The Home Office promotes voluntary departure schemes for migrants who may have overstayed and who wish to regularize their situation and potentially return to the United Kingdom later. Such schemes are clearly inappropriate for refugees who fear persecution in their countries of origin, and offering them to former asylum-seekers was construed by some informants as testament to the culture of disbelief that surrounds asylum claims and claimants.

\section{"Return" in an Afghan Context}

Gladwell and Elwyn consider the mechanisms involved in return and discuss why the young people in their study were so reluctant to take up offers of AVR. ${ }^{20}$ Their participants feared returning to a dangerous and unfamiliar environment where they felt they would have little chance of a future. Young people interviewed were not interested in the money or the support offered as part of AVR, and some saw absconding as an option, preferring to live below the state's radar without support to avoid enforced return. This desperate option was regarded as tenable by some, as they saw the United Kingdom as basically a safe country, even for people without rights to remain, unlike the alternative of Afghanistan.

Forced return is usually preceded by detention, and Gladwell and Elwyn describe how, when one young person was detained and/or returned, friends and acquaintances were more likely to drop out of the system. ${ }^{21} \mathrm{~A}$ clear picture emerges that young care-leavers do not want to return and will fight to stay in the United Kingdom. Many cannot imagine a future in Afghanistan, and the continuing state of unrest evidenced from multiple sources, including Facebook and social media, makes return a frightening prospect. Young people may have loose social networks that connect them back to countries of origin and to migrant communities, ${ }^{22}$ but they are still likely to be considered as outsiders in Afghanistan. Returning empty-handed is a further problem, especially for young men whose families may have invested heavily in getting them out of the country in the first place. Generalized insecurity and poverty in Afghanistan are also reported as problems for young people who have grown up in safety and relative affluence; their perceived Westernization may also cause them problems. Gladwell and Elwyn refer to assumptions that returnees
(C) Author(s), 2015. This open-access work is licensed under a Creative Commons Attribution-NonCommercial 4.0 International license.
Cette oeuvre en libre accès fait l'object d'une licence Creative Commons Attribution-NonCommercial 4.0 International. 
are wealthy (and therefore worth kidnapping), involved with foreign agencies, and/or ideologically aligned with the West. ${ }^{23}$ Schuster and Majidi's research identifies three factors that inhibit sustainable return once removed to Afghanistan:24 deep economic loss, lack of transnational ties, and shame of failure, compounded by community suspicions of "contamination."

There are few educational opportunities open to returnees in Afghanistan, and finding employment in Kabul is difficult without family connections and/or advanced skills. Literacy in Dari and Pashtu was also important, and an informant in Kabul stated that "a returnee has to be above and beyond a young person who has been to high school and college here."25 The long-term outcomes for returnees post-deportation are likely to include psychological damage, and it is clear that many returnees leave Afghanistan to seek safety elsewhere. ${ }^{26}$

Along with Morocco and Iraq, Afghanistan was identified in 2011 as the target of an EU-level drive to find durable solutions through the return of UASC. The European Return Platform for Unaccompanied Minors (ERPUM) aimed to develop reception centres in countries of origin and emphasized family reunification and tracing to reconnect children with their families and communities. It has been argued, however, that part of its failure "stems from normative questions concerning the illiberality of deportation powers as such" 27 and that the forced return of children remains a sensitive and controversial area of law. The ERPUM projects (I and II) were funded at the Eu level and aimed to "develop new methods for organizing family reunification and return for unaccompanied minors that need to return after receiving a final rejection of their asylum application."28 Thus ERPUM and the Positive Futures project, while at very different scales, had similar goals - to repatriate young asylum-seekers whose claims for protection had been judged unfounded. ERPUM failed because of bureaucratic difficulties and because of the political sensitivities of EU governments returning children. The Afghan Ministry for Refugees and Repatriation was unwilling to offer much support for the project, partly as the result of limited funding for accepting children whose safety they could not guarantee. The Positive Futures project discussed here failed directly because the young people refused to engage with and could not trust AVR without assurances of security and without adequate family tracing. Two elements-legal and bureaucratic barriers in sending and receiving countries-combined with the active objection to return by asylum-seekers and their advocates are likely to affect all future projects.

\section{The Positive Futures Project}

Positive Futures was initiated because of the growing number of ARECL young people in Kent. The project recognized the group's need for pre-return skills and training, not least as some ARECL have had little education in the United Kingdom. It had two elements: preparation for training and the training itself. Crucially, the terms of project funding and the participation of the Home Office meant that potential trainees had to apply for AVR before becoming eligible for the training course. The original evaluation plan intended to involve the young people in ongoing discussions about the project-how they felt about it, their situation in the United Kingdom, and their proposed return to Afghanistan. As it turned out, the project was over almost before it began as, although great efforts were made to engage ARECL, through their case workers, open days, and a week of preproject study skills, none of the nine Afghan young men who attended these sessions agreed to sign up for AVR and join the Positive Futures project. During the whole evaluation (the pilot and the main project) we spoke to twelve ARECL young people, eight caseworkers working directly with the ARECL, and twelve members of the steering group, including representatives of the Home Office, Immigration Enforcement, project staff, and four experts with experience working with ARECL. The data collection design was approved by the University of Kent Ethics Committee, and the full evaluation has been published online. ${ }^{29}$

Throughout our interactions with these young unaccompanied refugees we struggled to avoid the traps created by the administrative categories devised by immigration status and tried to focus on the young people as individuals. Arriving as unaccompanied children, they lack a family to contextualize their experience. Focusing on their lives as UASC, or ARECL, therefore, risks essentializing them and underestimating their individuality and their local and international connections. This research sought to present the views of people whose voices are rarely heard and whose experience represents a reality that mainstream society does not want to acknowledge. We were able to engage in a reflexive process to develop an understanding of individual experiences that gave meaning to their social reality. Nevertheless, there are ongoing concerns about the role of researchers and humanitarian advocates working with asylum-seekers and refugees, which include the possibility of colluding with practices that work against the human rights of informants. $3^{30}$ Research on deportation and removal could fall into this trap.

As stated above, this research is based on the experience of a small number of young people, as is common in projects seeking to engage potential returnees. We had no access to a larger data set, and young people without secure leave to remain are generally acknowledged to be hard to reach. ${ }^{31}$ We situate the experience of a small number of young people within a wider research field that has resonance
(C) Author(s), 2015. This open-access work is licensed under a

Creative Commons Attribution-NonCommercial 4.0 International license.
Cette oeuvre en libre accès fait l'object d'une licence Creative Commons Attribution-NonCommercial 4.0 International. 
for policy-makers internationally who struggle to support former UASC facing return to countries of origin. We aim to faithfully reflect the views of this small group of young people as expressed to us in a setting in which confidentiality was assured and where participants understood that we were impartial and unconnected to Social Services, the Home Office, or any other official agency.

\section{Lessons from the Project: A Lack of Educational Opportunities}

These UASC had had varied educational opportunities in the United Kingdom, as their routes into education were affected by many factors - not least their age assessment on arrival. Children placed in foster care are likely to receive more support and encouragement to study than those assessed as over sixteen and housed in semi-independent accommodation. These older children were, at the time, over the age for compulsory schooling so may not have been offered mainstream education. The local area is over 89 per cent white $^{32}$ and schools are inexperienced at working with children with additional languages; they are reluctant to take on teenagers new to the UK school system. Many UASC in Kent have received education from a voluntary organisation funded by the LA that provides twenty hours of teaching per week in English, everyday maths, British culture, and some vocational skills. This is unlikely to meet the needs of the UASC, who arrive with little education and are unprepared to join mainstream schooling. Education provision is just one way that support for UASC differs across the United Kingdom, as in other British LAs, education post-sixteen has been more comprehensive. 33

Several of the young people interested in joining the project were functionally illiterate in their own language so were at a serious disadvantage when learning English or vocational skills. That said, they were enthusiastic about having a chance to study at a Further Education ( $\mathrm{FE}$ ) college. Our conversations and the reports written for the evaluation by the trainer and the keyworker show how the young people were very positive about participating and they were eager to learn. The poor mental health status of these young people, however, should not be overlooked. Worry and anxiety undermined their learning and shortened their attention span. One stated, "We are slowly going mad." They told us they could not sleep at night and were tired during class. Sleep disturbance was, in part, due to fear for the future and of night-time raids by the ICE teams but also may relate to pre-migration and flight experiences.

Education is valued highly in Afghanistan, and we heard that nothing short of a degree would allow a young person to return with dignity and a good chance of a livelihood. Indeed Schuster and Majidi state, "Where those deported are seen as shamed or contaminated, access to such networks may be withdrawn. Without networks to offer support and employment opportunities, integration into a community is almost impossible." 34

The young people we spoke to were motivated in part by the project's promise of some respite from reporting and from being detained and forcibly removed. One said, "The good thing that they say to us is that you don't need to go sign and that Immigration and the Police can't touch you because you are going to this course-that is exciting. We can walk free, we can go out free. We don't have to worry too much like we used to be. But we are still thinking-what's it going to be after three months? Same again — but at least we can breathe for three months."

\section{Lessons from the Project: AVR and Young Care- Leavers from Afghanistan}

The young people we spoke to were clear that return was not an option for them, and they stressed that the original reasons they left their homes still remain. They were also clear that they had often been told by their caseworkers about AVR and that they had discounted it. "We know about it! If you want to go back you can go but we don't want to-we come here from 2009 and we know about this stuff-we got a problem how can we go back?"

The Home Office's preferred option for ARECL remains, however, AVR. The alternatives-forced return or voluntary departure (by which migrants leave without support packages) - are both undesirable and in the case of forced return, expensive and traumatic for all involved. Our interviews with ICE made it clear that forced return is complex and involves locating and detaining young people. Enforcement raids are potentially public and traumatic events. The Home Office has a clear interest in keeping in touch with the young people so that they can note the progress of cases as well as keep their information systems up to date. A key indicator of the success of the Positive Futures project, from the Home Office's point of view, was that engagement encouraged young people who had not been reporting to re-present themselves and thus to place themselves back within the state's purview.

AVR is a contested subject, and we heard views from stakeholders ranging from those who saw it as a positive option to those who opposed it as a form of quasi non-voluntary removal. There was a majority view, however, that AVR is unlikely to be an attractive option for this group of young people because of their age and their sincere fear of return. This reluctance to volunteer to return was reinforced by their continuing hopefulness that they would be able to legitimize their stay in the United Kingdom. Some we spoke to felt that age and gender mattered and a masculine
(C) Author(s), 2015. This open-access work is licensed under a Creative Commons Attribution-NonCommercial 4.0 International license.
Cette oeuvre en libre accès fait l'object d'une licence Creative Commons Attribution-NonCommercial 4.0 International. 
attitude to risk meant that, in their situation, "You'd take your chance" rather than accept voluntary return. Another informant considered that conditions in the United Kingdom, although not easy, were so much better than those in Afghanistan, that no amount of pressure or incentive would be enough.

\section{Lessons from the Project: AVR and Incentive to Return}

The project was not an incentive for any of the ARECL to apply for AVR. What was offered-training and the highest rate of financial reintegration support-did not outweigh their fears. When they met the Choices team at the end of the preliminary week, the young people, who had not fully understood that they must commit to return to receive the training, left the program, and those we were able to speak to were angry and very disappointed in how things had turned out. We were told,

We were thinking we can go to college, we can do anything, we can learn, but then they said we must sign and go back. I know that ... I've been in detention, I know that every single day about this thing, they can give some money and you can go back to Afghanistan to live there-what am I going to do with that money if I haven't got family? If I go somewhere and they see me I've got money, they lift from me, and get money from me, they might kill me as well. I've got problems as well, I've got problem with that people as well-if they find me out, they are not give me a chance. It's not right.

His friend continued, "Those people, they are not going to listen to you, they are going to shoot you. It's not like England!"

This and other data collection exercises ${ }^{35}$ has shown that while their lives are very hard in the United Kingdom-being disqualified from education and employment and threatened with detention, homelessness, and destitu$\operatorname{tion}^{36}$-it is still a great deal better than what they expect to find in Afghanistan. As the report on a uk Border Agency and Foreign and Commonwealth Office workshop acknowledges, the "push factors" at the disposal of the Home Office are rarely enough to change a young person's mind:

Push factors include: the prospect of detention and enforced removal (although there are differing views as to how much this prospect influences decisions); the lack of options or opportunities in the UK; the tightening of immigration laws (including moves to further limit legitimate migration); destitution-sometimes triggering the need to resort to unlawful activity in order to survive; and a mismatch of reality with optimistic, or even misguided, expectations of life in the UK prior to arrival ... However, compelling factors such as destitution can limit the individual's ability to engage with long-term considerations and planning for return. ${ }^{37}$

Our discussions with experts within and outside the steering group indicates skepticism about the appropriateness of AVR for ARECLS. Some service providers involved in this project felt that AVR should be presented to young asylumseekers as soon as they arrived in the United Kingdom, while others were reluctant to bring up the subject for fear of implying a lack of confidence in the young person's asylum claim and their right to be in the United Kingdom. Finding the right time to raise the delicate issue of returning "home" is difficult. Our conversations with young people illustrated that while they were clear about AVR as an option, they had not realized how tightly enmeshed it was within the project. This failure of communication led directly to the collapse of the project, as while members of the steering group were clear that openness and honesty with the young people was paramount, the centrality of AVR had been downplayed. Within the general skepticism about the appropriateness of voluntary return for this group, we heard the view that former asylum-seekers will take up AVR only once they had reached a point when return feels desirable or inevitable. These young people have not reached this point and are genuinely afraid of what is waiting for them in Afghanistan and still hoping for leave to remain at "home" in the United Kingdom.

There were discussions about the levels of support offered to returning migrants and of the ratio of cash to paymentin-kind. We heard that few migrants return because of the financial incentive and that Afghanistan is not short of tradespeople or training programs. We were told by an expert, "Vocational training is not enough, there are loads of training-providers in Afghanistan. Lots of people know how to do these things who have networks and contacts and don't have the disadvantages that returnees have-it's helpful to the extent that any training is helpful but not the critical factor that will change things unless it was linked to completely reliable and verified job-creation servicesthat's the only way it would have made a difference."

\section{Conclusions: Returning Young Unaccompanied Asylum-Seekers}

We have described some of the reasons, common to many receiving countries, why projects seeking to return young unaccompanied people to countries of origin voluntarily, fail. Without wishing to promote the option of return, we recognize that some young people's best interests would be served by a genuinely informed and sensitively arranged return, to at least "test the water" in their countries of origin.
(C) Author(s), 2015. This open-access work is licensed under a Creative Commons Attribution-NonCommercial 4.0 International license.
Cette oeuvre en libre accès fait l'object d'une licence Creative Commons Attribution-NonCommercial 4.0 International. 
The final section of this paper thus considers what the Positive Futures project taught us about how such an option could be designed.

\section{Comprehensive Training and a Bigger Project}

The young people involved in this project made it clear that return was not an option for them. The majority of the steering group, however, felt that return was in the best interest of the child and that developing pre-return packages had some value. While it was inappropriate for this group of young people, we feel that some young people, from countries that are safe and developing, could benefit from prereturn training packages. There are therefore some general lessons to draw from this project.

Several steering group members felt that the length of time allotted to the project was too short. Insufficient time was allotted to gain the trust of the young people, to find out about their needs, to build links in countries of origin, and to accustom them to the situation that they would face there. The terms of the funding and Home Office's concerns that a longer course might act as a pull factor for more asylum claimants limited the project, but there was a common feeling that the lead-in time was too short and the training too superficial to be valued by the young people. In the case of the Afghan young people, however, they challenged the idea that any kind of training could be sufficient to persuade them to return.

During the evolution of the project, from an idea before 2012 to a funding application in 2013, the project became less ambitious. The originators of the project attempted to engage agencies working in Afghanistan to explore what the options for returnees might be. They consulted the IOM, who have significant links in Afghanistan and who provide support for returning migrants, on the sorts of skills that were likely to be useful on return. They built links with organizations such as Afghan Action and the Afghan Professionals' Network. A more extended program could have allowed the young people to think, talk over their options, and settle into preparatory study without having to commit to return. After this introduction, they could choose a course of study that would suit them and give them a realistic chance of work on return. Staff at the FE college spoke of how the young people were uncomfortable in the classroom; they arrived late, found it hard to concentrate, and were excited but suspicious of their unfamiliar surroundings. Staff felt that e-learning techniques, including Skype, could have allowed them to access learning in an environment where they felt comfortable. They could have overcome their nervousness and fear of being "trapped" at the course while building skills and familiarity with the college. This approach would also have been more cost effective and a "softer introduction" to learning for young people living chaotic lives.

In the current political climate, a comprehensive course of study is unlikely to be politically acceptable, but we argue that the fears that prevent funding - that such a course is a "pull factor" and that investment should not be made in people ineligible for support in the country-are not insurmountable. We find no evidence to support the belief that a course would act as a pull factor, and, given the cost and political sensitivity of detention, forced removal, and destitution, interventions supporting return could be justified on financial grounds and certainly on ethical grounds.

\section{A "Cultural" Approach to Supporting UASC and Young People}

Introducing voluntary return to young people when they are facing the loss of their support from social services is too late. We heard from the young people themselves and many other parties that they were too scared and too angry to accept return and AVR at this late stage.

An alternative approach could be to introduce the option of return much earlier in care planning. Training and support for social workers who have to balance the tension between care and immigration matters is critical here $3^{8}$ Careful and sensitive handling is needed to ensure that AVR is presented as genuinely voluntary and a positive choice. Such an approach could run alongside the provision of good and equitable educational opportunities in mainstream UK schools leading to British qualifications. Education could include mother-tongue classes, which would support learning generally and help young people develop a sense of pride in their own heritage. It could encourage a sense of belonging and biculturalism that would allow them space to think positively about returning to Afghanistan.

For the young people we spoke to, Afghanistan is not "home"; home is where they have grown up, and they know nothing about their country of birth. Most of them have few if any connections to draw on, and those who do are unlikely to admit to them for fear they will be used to force them back. Connections and social networks in Afghanistan could be promoted from the United Kingdom, and family-tracing services could be used proactively and independently of immigration processes to develop the few links these young people have. Such a cultural approach is in line with Elaine Chase's findings ${ }^{39}$ and the "Life projects" approach discussed by Matthews. ${ }^{40}$ This approach, connected to Article 3 of the UNCRC and developed by the Council of Europe ${ }^{41}$ aims to promote the best interest of the child and the future prospects of all concerned with their welfare and protection. Matthews writes, "The Committee of Ministers envisages life projects ... as being implemented
(C) Author(s), 2015. This open-access work is licensed under a

Creative Commons Attribution-NonCommercial 4.0 International license.
Cette oeuvre en libre accès fait l'object d'une licence Creative Commons Attribution-NonCommercial 4.0 International. 
either in the host country or in the host country and in the country of origin or in the country of origin or, in the specific case of family reunion, in a third country in which the parents are lawfully settled." 42

Equipping young persons with cultural skills appropriate to a future in the United Kingdom as well as in their country of origin surely has great potential for supporting them to be truly contributing citizens wherever their lives take them.

\section{Changing the Political Climate}

Funding for ARECL remains contentious. Local authorities are financially responsible for providing care (subject to a human rights assessment), while the Home Office's role is as an enforcement agent. The resulting tension over financial liability needs to be resolved if more holistic approaches to the care and support of ARECL are to be achieved. We find it disturbing that a group of young people who have already experienced disruption, loss, and disadvantage in their short lives should be treated as a burden rather than as potential contributing members of society, whether in the United Kingdom or in Afghanistan. Writing ten years ago, Blitz, Sales, and Marzano argued, "Domestic interest based arguments, rather than those founded on the protection of human rights, appear to be driving the policy-making agenda. Thus returns are portrayed as a means of relieving the burden on Britain's social services, and as a means of placating a public opinion and media that has become increasingly hostile to immigrants and asylum seekers." 43

This observation has become only more striking in the intervening years. While we argue that not enough has been invested in the care and education of UAsc before they reach eighteen, we find it unethical and counterintuitive not to support their transition into adulthood, either through allowing them to work or through meaningful education or training programs. Our reflections on the Positive Futures project highlight some of the complexities experienced by Afghan ARECL. The project attempted to tackle one area of this complexity through an innovative approach, but the project failed, we would argue, because of the political climate in the United Kingdom and beyond. Afghan careleavers are well aware that asylum decision-making is not equivalent across Europe, and we heard examples of young people leaving the United Kingdom clandestinely and gaining refugee status elsewhere. Even in this small sample within one local authority, these young people have had an inconsistent experience, with fostered children better able to access mainstream education than those supported in independent housing.

Government policy on migration controls still privileges neo-classical models of "push and pull" to explain and understand the motivations of migrants and refugees, despite academic research that now generally accepts pushpull theories as outdated and unhelpful in predicting migration decision-making. ${ }^{44}$ Conversations with steering group members made it clear that the project design was driven largely by funding streams that insisted on a strong "push"obligatory application for AVR before Phase Two, combined with a weak "pull"- enough to get the ARECL into the classroom but not enough to encourage new asylum-seekers into the country. This project failed, as have other projects, because it did not recognize that young people seeking safety in the United Kingdom are active agents who will strive for their own best interests, which they perceived to be served by remaining in their UK home, not in countries of origin. 45

Kim Robinson is a lecturer in social work. She has been a social work practitioner and manager in community health and refugee services for over twenty-five years in Australia and in the United Kingdom. Her research interests include the application of critical theory perspectives, particularly post-structuralism and feminism, to inform social work practice and education. She is also writing on domestic violence and refugees, and unaccompanied asylum-seekers leaving care. After working in the United Kingdom for the past thirteen years she has returned to Australia as lecturer in social work at Deakin University. The author may be contacted at kim.robinson@deakin.edu.au.

Lucy Williams is a visiting senior research fellow, University of Kent, and independent researcher. She has a longterm research interest in the health and social well-being of migrants, particularly those who are facing destitution, detention, and deportation. The author may be contacted at l.a.williams@kent.ac.uk.

\section{Notes}

1 Equal authorship.

2 Jill De Paolis, "Kent's Looked-After Children and Care Leavers Strategy," draft March 2015, http://www.kent.gov. uk/__data/assets/pdf_file/oo13/32251/Looked-after-Children-and-Care-Leavers-Strategy.pdf.

3 "Kent Sees 'Unprecedented' Increase in Lone AsylumSeeker Children," BBC, 3 September 2015, http://www.bbc. co.uk/news/uk-england-kent-34139364.

4 Liza Schuster, "Afghan Perspectives on erpum," in The Deportation of Unaccompanied Minors from the EU: Family Tracing and Government Accountability in the European Return Platform for Unaccompanied Minors (ERPUM) Project, workshop report 3 May, ed. Martin Lember-Pedersen,
(C) Author(s), 2015. This open-access work is licensed under a Creative Commons Attribution-NonCommercial 4.0 International license.
Cette oeuvre en libre accès fait l'object d'une licence Creative Commons Attribution-NonCommercial 4.0 International. 
Liza Schuster, Rebecca Stern, Matthew J. Gibney, and Jennifer Allsopp, 13-15 (Oxford: Refugee Studies Centre, Oxford Department of International Development, University of Oxford, 2013).

5 Home Office, Country Information and GuidanceAfghanistan: Security and Humanitarian Situation, version 2 (London: Home Office, 2015), https://www.gov.uk/ government/uploads/system/uploads/attachment_data/ file/455129/CIG_AFG_security_situation_August_2015.pdf.

6 Heaven Crawley, Child First, Migrant Second: Ensuring That Every Child Matters (London: Immigration Law Practitioners Association, 2006).

7 UNHCR, "Durable Solutions," http://www.unhcr.org/ pages/49c3646cf8.html.

8 Matthew J. Gibney, "Ethical Reflections on ERPUM," in Lember-Pedersen et al., Deportation of Unaccompanied Minors from the EU, 23-8.

9 Martin Leberg-Pedersen, "The Evolution of the ERPUM Project," in Lember-Pedersen et al., Deportation of Unaccompanied Minors from the EU, 4.

10 Elaine Chase, Future Citizens of the World? The Contested Futures of Independent Young Migrants in Europe (Oxford: Refugee Studies Centre, Oxford Department of International Development, 2013); Nathalie Peutz, "Embarking on an Anthropology of Removal," Current Anthropology 47, no. 2 (April 2006): 217-41; Liza Schuster and Nassim Majidi, "Deportation Stigma and Re-migration," Journal of Ethnic and Migration Studies 41, no. 4 (2015): 635-52.

11 Kim Robinson and Lucy Williams, Positive Futures: A Pilot Project to Develop and Test a Model to Assist Appeal Rights Exhausted Care Leavers to Consider Assisted Voluntary Return, 2014, South East England Councils, http:// www.secouncils.gov.uk/wp-content/uploads/2012/o4/ Positive-Futures-Evaluation-Report-Final-18-Aug.pdf.

12 Jim Wade, "Preparation and Transition Planning for Unaccompanied Asylum-Seeking Young People: A Review of Evidence in England," Children and Youth Services Review 33 (2011): 2424-30; Francis Wright, "Social Work Practice with Unaccompanied Asylum-Seeking Young People Facing Removal," British Journal of Social Work 44, no. 4 (2014): 1027-44.

13 Adrian Matthews, "What's Going to Happen Tomorrow?" Unaccompanied Children Refused Asylum (London: Office of the Children's Commissioner, 2014).

14 Richard Warren and Sheona York, How Children Become "Failed Asylum Seekers": Research Report on the Experiences of Young Unaccompanied Asylum-Seekers in Kent from 2006 to 2013, and How "Corrective Remedies" Have Failed Them (Canterbury: Kent Law Clinic, University of Kent, 2014).

15 Catherine Gladwell and Hannah Elwyn, Broken Futures: Young Afghan Asylum Seekers in the UK and in Their Country of Origin, Research Paper No. 246 (Geneva: UNHCR Policy Development and Evaluation Service, 2012), http:// www.unhcr.org/5098d2679.html.
16 Katia Bianchini, "Unaccompanied Asylum-Seeker Children: Flawed Processes and Protection Gaps in the UK," Forced Migration Review 37 (2011): 52-3.

17 KA (Afghanistan) \& Ors v Secretary of State for the Home Department [2012] EWCA Civ 1014 (25 July 2012), http:// www.bailii.org/ew/cases/EwCA/Civ/2012/1014.html.

18 http://www.politics.co.uk/blogs/2015/o4/22/afghandeportations-cancelled-at-last-minute-ahead-of-possib. "Duncan Lewis Solicitors Obtain Unprecedented Generic Injunction from the Court of Appeal in Relation to Removals to Afghanistan," 24 August 2015, http://www. duncanlewis.co.uk/news/Duncan_Lewis_Solicitors_ obtain_unprecedented_generic_injunction_from_the Court_of_Appeal_in_relation_to_removals_to_Afghanistan._\%2824_August_2015\%29.html.

19 David Turton and Peter Marsden, "Taking Refugees for a Ride? The Politics of Refugee Return to Afghanistan," Afghanistan Research and Evaluation Unit, Issues Paper Series European Commission Humanitarian Aid Office, 2002; Richard Black, Michael Collyer, and Will Somerville, Pay-to-Go Schemes and Other Noncoercive Return Programs: Is Scale Possible? (Washington DC: Migration Policy Institute, 2011).

20 Gladwell and Elwyn, Broken Futures.

21 Ibid.

22 Karen Wells, "The Strength of Weak Ties: The Social Networks of Young Separated Asylum Seekers and Refugees in London," Children's Geographies 9, nos. 3-4 (2011): 319-29.

23 Gladwell and Elwyn, Broken Futures.

24 Liza Schuster and Nassim Majidi, "What Happens PostDeportation? The Experience of Deported Afghans," Migration Studies 1, no. 2 (2013): 221-40; Schuster and Majidi, "Deportation Stigma and Re-migration," Journal of Ethnic and Migration Studies 41, no. 4 (2015): 635-52.

25 Gladwell and Elwyn, Broken Futures, s. 6.7.

26 Schuster and Majidi, "Deportation Stigma and Re-migration"; Schuster, "Afghan Perspectives on ERPUM."

27 Martin Lemberg-Pedersen, "The Rise and Fall of the ERPUM Pilot: Tracing the European Policy Drive to Deport Unaccompanied Minors," Refugee Studies Centre Working Paper Series No. 108, April 2015.

28 ERPUM (2014): 6, cited in ibid., 7.

29 Robinson and Williams, Positive Futures.

30 Heike Drotbohm and Ines Hasselberg "Deportation, Anxiety, Justice: New Ethnographic Perspectives," Journal of Ethnic and Migration Studies 41, no. 4 (2015): 551-62; Susann Huschke, "Giving Back: Activist Research with Undocumented Migrants in Berlin," Medical Anthropology 34, no. 1 (2015): 54-69.

31 Alice Bloch, Nando Sigona, and Roger Zetter, Sans Papiers: The Social and Economic Lives of Young Undocumented Migrants (London: Pluto, 2014).

32 "Equality and Diversity," Kent County Council, http:// www.kent.gov.uk/about-the-council/information-
(C) Author(s), 2015. This open-access work is licensed under a Creative Commons Attribution-NonCommercial 4.0 International license.
Cette oeuvre en libre accès fait l'object d'une licence Creative Commons Attribution-NonCommercial 4.0 International. 
and-data/Facts-and-figures-about-Kent/equalityand-diversity-data.

33 Matthews, "What's Going to Happen Tomorrow?"

34 Schuster and Majidi, "What Happens Post-Deportation?," 231.

35 Ibid.; Gladwell and Elwyn, Broken Futures; Matthews, "What's Going to Happen Tomorrow?"

36 Lucy Williams, "From Immigration Detention to Destitution," Criminal Justice Matters 99, no. 1 (2015): 12-13.

37 Steven Hall, Assisted Voluntary Returns: Working Together for Greater Effectiveness (WP1193), conference report 4-6 July 2012, https://www.wiltonpark.org.uk/conference/ wp1193/.

38 Kim Robinson, "Voices from the Front Line: Social Work with Refugees and Asylum Seekers in Australia and the uk," British Journal of Social Work 44, no. 6 (2013): 1602-20.

39 Elaine Chase, "Security and Subjective Wellbeing: The Experiences of Unaccompanied Young People Seeking Asylum in the UK," Sociology of Health \& Illness 35, no. 6 (2013): 858-72.
40 Matthews, "What's Going to Happen Tomorrow?" 82-8.

41 Council of Europe, "Recommendation CM/Rec (2007)9 of the Committee of Ministers to Member States on Life Projects for Unaccompanied Migrant Minors," https:// wcd.coe.int/ViewDoc.jsp?id=1164769.

42 Ibid., 83, emphasis in the original.

43 Brad Blitz, Rosemary Sales, and Lisa Marzano, "NonVoluntary Return? The Politics of Return to Afghanistan," Political Studies 53, no. 1 (2005): 196.

44 Stephen Castles, "Twenty-First-Century Migration as a Challenge to Sociology," Journal of Ethnic and Migration Studies 33, no. 3 (2007): 351-71; Stephen Castles and Mark J. Miller, The Age of Migration: International Population Movements in the Modern World, 4th ed. (London: Macmillan, 2009).

45 We acknowledge the valuable comments of the three anonymous reviewers of this text.
(C) Author(s), 2015. This open-access work is licensed under a

Creative Commons Attribution-NonCommercial 4.0 International license.
Cette oeuvre en libre accès fait l'object d'une licence Creative Commons Attribution-NonCommercial 4.0 International. 


\title{
Book Reviews
}

\author{
Adjudicating Refugee and Asylum Status: The Role of Witness, Expertise and Testimony \\ $\sim$ \\ Edited by Benjamin N. Lawrance and Galya Ruffer \\ New York: Cambridge University Press, 2015
}

A djudicating Refugee and Asylum Status is an excellent collection that explores how, in industrialized countries, the personal narratives of asylumseekers are scrutinized and in some instances replaced by an expanding array of expertise deployed to establish the credibility of asylum claims. The ten chapters were drawn from an international conference in 2012, and the authors comprise a diverse array of academics and practitioners reflecting a wide disciplinary field.

The volume examines the discursive production of refugees through what the editors describe as the "asylum dialectic" (5). They define this concept broadly in terms of the "performance of legal process as the dialectical relationship between asylum adjudicators and expert witnesses" (6). Through detailed and fascinating case studies, examples, and personal reflections, it considers how the credibility of refugee claimants is increasingly determined on the basis of a "productive interdependence" (6) between adjudicators and the experts that inform their judgments. These interdependencies do not necessarily establish the "hard facts" of refugee claims but focus on more intimate and indirect betrayals, traces and confirmations of identity, presence, and experience. Importantly, this book approaches such expertise not simply as judicial progress or technical enlightenment, but as reflective of a global political order that is less concerned with the protection of the rights of those who have fled their countries and more intent on proving (or disproving) testimonies of suffering and persecution. The book therefore offers a critique of the increasing use of technologies of suspicion in refugee status determinations, as well as the arbitrariness of its deployment and the inaccuracy of some of its claims. The book covers both well-established and emergent forms of expertise that appear in asylum adjudications. It provides useful insight into the dynamics of country of origin expertise (or COI), linguistic, medical, and psychological assessments, as well as potential of biometrics and genetics. Each chapter offers expanded case studies, detailed discussion, as well as thoughtful reflection on the roles and responsibilities of experts. The richness of these different perspectives contributes greatly towards strengthening both the interest and analytical value of this unique collection.

Following a thought-provoking and comprehensive introduction, the substantive section of the book is divided thematically into two parts. Part I explores how tensions that arise from social and cultural misunderstanding play out in asylum adjudications, highlighting the role of experts in both reconciling and aggravating them. "Reconstructing Babel," by Einhorn and Berthold, includes revealing insight into an experienced United States immigration judge's efforts to make sense of the narratives of asylumseekers in a legal context that offers little formal clarity or guidance. This exposes a strong personal and professional commitment that is frequently missing from less nuanced critiques of asylum adjudication processes. The chapter by Kam, which follows, is a fascinating account of the emergence of language analysis as a technique for uncovering the "true identity" of asylum-seekers in Europe. This particularly detailed piece exposes multiple reasons to question the authoritative claims of language analysis as a reliable determinant of national origin. Two disturbing studies that follow examine testimonies of rape survivors and the potentially ambiguous, haphazard, and ultimately flawed role of experts in establishing their credibility follow. The piece by Ruffer considers how the notion of rape is configured in asylum contexts in narrow terms of political persecution, set in contrast to the broader experience of rape as a pervasive consequence of gender identity for many victims. Marton's chapter expands on this exploration of rape victims as vulnerable to further abuse and trauma by the adjudication,
(C) Author(s), 2015. This open-access work is licensed under a

Creative Commons Attribution-NonCommercial 4.0 International license.
Cette oeuvre en libre accès fait l'object d'une licence Creative Commons Attribution-NonCommercial 4.0 International. 
and the role of experts in either addressing or worsening this situation. Good's chapter concludes this section on cultural misunderstanding by highlighting the increasingly prominent role that country of origin information plays in judicial decision-making in asylum cases. In this instance, Good contrasts the notions of ethnographically derived forms of cor knowledge and legal evidence, highlighting some of the tensions that arise between them.

Part II examines the increasingly prominent role of medical expertise in the adjudication of asylum-seekers. The chapter by Ardalan, "Expert as Aid and Impediment," explores, from the perspective of an attorney who represents asylum-seekers, how expert testimonies are not always consistent, further undermining the credibility of claimants in ways that may be unfair, unintended, and arbitrary. This chapter highlights the need for close collaboration between experts and attorneys, to avoid the risks of such misunderstanding. The report by Chelidze et al. considers survivors of torture and the forms of expert psychiatric care that they receive, or don't receive, as the case may be. It describes the approach of a medical human rights clinic run by students in New York City, which provides forensic evaluation to survivors of torture and persecution that include a range of medical and psychological interventions. The chapter by Smith et al., "Incredible Until Proven Credible," focuses on the role of experts where asylum claims are adjudicated on the basis of mistrust. It highlights how the testimonies of mental health experts are produced in ways that may vary considerably, suggesting widespread inconsistency and limitations of certainty of opinion. Contrary to the intentions of adjudicators, mental health practitioners may be limited in their contributions towards uncovering deception by asylum-seekers and its causes, or identifying the precise cause of individual trauma or distress. Furthermore, mental health assessments may be conducted in environments where asylum-seekers are subject to the ordinary effects of time on memory, poor translations, fear of the process, or the embellishment of facts out of desperation or at the suggestion of both well-meaning and mischievous third parties. Whilst these factors may erode the chances of a successful claim, their careful exploration skilled clinicians may also enhance refugee credibility. The chapter highlights in particular the burden of proof that is placed on African asylum-seekers to demonstrate their credibility and how their efforts to confront it may produce the opposite effect. The chapter by Tutton et al. explores growing state interest in forensic biomedicine as a tool for determining the national identity and geographic origins of asylum-seekers. Noting that some claims of accuracy of genetic testing for ancestry and isotope-testing for this purpose are still open to question, the authors examine government experiments to expand this technology in refugee adjudications. The discussion focuses on a pilot project conducted between 2010 and 2011 in the United Kingdom, which the authors argue contributed towards "a vicious circle of criminalization and victimization of asylum seekers," advancing the replacement of testimonies of asylum-seekers with highly impersonal methods of genetic and biological markers of ineligibility. The final chapter, by Lawrance, develops out of a comparison between two similar cases of migrant struggles to maintain access to health care in European countries, under the threat of forced return to their respective countries of origin. The outcomes were very different, and the author uses this to explore the important role of human rights protection in health-related claims.

The strength of this important collection lies in the range of professional perspectives that it reflects-often candid, self-critical, and modest in their struggles to establish truth, credibility, and state of mind. For the most part, this is not a story of heroes and villains, but one of collective dedication to an imperfect system and frustration at the limits of ensuring fair asylum procedures and outcomes. Overall it does a superb job of linking the discursive shift in state representations of refugees-from rights-bearing subjects to purveyors of deception-to the roles and functions of experts in responding to this shift. Regrettably, despite its practitioner-oriented focus and intentions, Adjudicating Refugee and Asylum Status offers few clear practical solutions, beyond fairly general calls for more collaboration and increased sensitivity to the complex predicaments of asylum-seekers. This is not necessarily a shortcoming of the book, but perhaps reinforces the intractability of some of the problems that it seeks to highlight.

Graeme Rodgers is technical advisor, research, at the International Rescue Committee in New York. Trained as an anthropologist, he has conducted extensive research on refugees and internal displacement in both urban and rural settings, mostly in Africa. His work focuses on refugee resettlement in the United States. The author may be reached at graeme.rodgers@gmail.com.
(C) Author(s), 2015. This open-access work is licensed under a Creative Commons Attribution-NonCommercial 4.0 International license.
Cette oeuvre en libre accès fait l'object d'une licence Creative Commons Attribution-NonCommercial 4.0 International. 


\section{Migrant Women of Johannesburg: Life in an In-Between City \\ Caroline Wanjiku Kihato \\ Johannesburg: Wits University Press, 2013}

C aroline Kihato's ethnography of migrant women in Johannesburg provides the reader with productive disruptions. It disrupts our thinking about African cities. It disrupts binaries of insider/outsider, legal/illegal, formal/informal that shape the migrant experience. It shakes the foundations of recent scholarship on urban governance, and it requires the reader to re-examine the complexities of the margins, where migrant urban lives and livelihoods in Johannesburg-like the city itself-are in a constant state of becoming. The visual methods the author employs contribute not only to our understanding of women's public and private lives; they also bring attention to photography as a "method of analysis and theorization of the city" (117). A number of salient themes emerge strongly from Kihato's carefully rendered work. In combination they shed light on the city from "below" and highlight the migrant experience of entanglement, liminality, and mobility from a reflexive point of departure.

\section{Reflexivity}

The journey from self (home) to research (field) involves a journey into the contact zone ${ }^{1}$ where the researcher negotiates the self and the "other." The contact zone is "a social space where cultures meet, clash, and grapple with each other, often in contexts of highly asymmetrical relations of power." The boundary between "field" and "home" in Kihato's work is a productively blurred one. This borderland is the site of a subject/object performance where science tells us the researcher must be detached from bias while searching for truth. In practice, however, we never fully disengage from the self as we step into the street and move toward the subject in the field. Rather, we operate within a dynamic contact zone situated somewhere between field and home. It is in these interstices where contact shapes how we see, who we see, and what possibilities for knowledge transfer and production emerge. Kihato's reflexive position provides a constructive point of departure.

The preface to Migrant Women of Johannesburg takes us into this contact zone by reflecting on a question that was asked of her by a fellow Kenyan who was sheltering from xenophobic attacks in Johannesburg in May 2008. The simple question "Where do you come from?" is used to frame the experiences of the migrant women she so carefully explores, but it also signals a moment of deep reflection about belonging, place, and identity that permeates the methods, analysis, and contribution of the research underpinning her work. Kihato draws on the intellectual wallpaper lining her memories of childhood home in Kenya, asking her to trace her own migrant journey. The narratives of migrant women such as Fazila, Jean, Rosine, Namwene, and many others who provide the book's empirical backbone seem to inhabit a perpetual state of flux, somewhere "in-between." While this liminal state evokes feelings of "sympathy, compassion and kindness" (110) in response to the vulnerability of living lives at the margins, the author demonstrates that such thinking blinds us to the power and resilience of migrant communities.

\section{Liminality}

The productive nature of the liminal state is further explored in the chapter evocatively entitled "Between Pharaoh's Army and the Red Sea." In-betweenness characterizes not only the lives of those women that Kihato explores; it is also a state in which the author finds herself as a migrant, having come to Johannesburg at the dawn of South Africa's democracy with hopes of a brighter future. Through deeply rooted participant observation, and the application of visual methods throughout four years of ethnographic fieldwork, Kihato skilfully employs feminist approaches that push at the boundaries of our notion of liminality. She demonstrates how the lives of cross-border migrant women defy binary logics. Such defiance is illustrated in chapter 2 where a legal "notice" is served to informal trader Hannah for her contravention of Johannesburg's informal trading by-law. The failures of the state to capture and control the mobility of traders like her are exhibited in the incomplete details on the notice. Hannah's ability to productively engage her marginality is complicated by the state's inability to trace her "structural-legal invisibility" (33). Hannah's story is typical of migrant women who live somewhere between legitimacy and illegality. That is not to say that liminality provides a fluid medium through which migrant women may transition easily. As she notes, "Johannesburg is a liminal space ... [where migrant women] are caught in its vortex, unable to move onto other destinations because they lack the material means to do so" (69).
(C) Author(s), 2015. This open-access work is licensed under a

Creative Commons Attribution-NonCommercial 4.0 International license.
Cette oeuvre en libre accès fait l'object d'une licence Creative Commons Attribution-NonCommercial 4.0 International. 


\section{Entanglement}

While Johannesburg may indeed be a liminal city, it nonetheless is situated at the heart of African cross-border migrants' desires, drawing so many into its centrifuge as the narratives attest. Within the vortices of the city, migrant women's lives are thus entangled in legal and socially embedded mobilities. Seen in this light, Kihato demonstrates how the liminal city is generative and a "gateway rather than a ghetto" (129), where entanglements transform migrants' social status while they also illustrate migrant women's tactical relationship to the city. The relationship that migrant women of Johannesburg have with the city is intertwined with the politics of survival against pressures imposed by culture, laws, and incidents of violence upon which Kihato reflects in three vignettes emerging from xenophobia in South Africa in 2008. Drawing upon-and extendingSen's $s^{3}$ "capabilities approach," Kihato illustrates how migrants' capabilities are limited by their liminality and their socially embedded mobility. Beyond a social-capital thesis, the author underscores the political nature of mobility, and the ways that mobility forms the foundation of the migrant experience.

\section{Mobility}

Seen through the prism of the "new mobilities paradigm,"4 the mobile lives of cross-border migrants disrupt the formerly static nature of the social sciences. Kihato's work may be understood as a response to Sheller and Urry's challenge to re-examine relationships between materiality and mobility. If we understand mobility as an "entanglement of movement, representation and practice," 5 then the narratives of Kihato's migrant women add new dimension to the relationship between material and mobile lives. The migrant women in her book exemplify mobility not only through their physical movement from "Home" (where they come from) to their adopted "home" in Johannesburg as a rite of passage, but also social mobility where social status is meant to be transformed through cross-border migration, and demonstrated materially through remittances and gifts, and symbolically through photographic evidence of their success in a new city.

The sum of migrant women's stories in Migrant Women of Johannesburg disrupts conventional views of the African city and its governance from "above" and allows a view of the city from "below" that speaks to "how urban dwellers navigate the city, access urban resources, and related to the state and others" (124). Using their own vocabularies, voices, and eyes through visual methodologies, Kihato demonstrates that migrant communities have agency that is realized in liminal spaces, through entangled relationships to people and place, in the context of highly politicized and mediated mobile lives.

\section{Notes}

1 M.L. Pratt, "Arts of the Contact Zone," Profession 91 (1991): 33-40.

2 Ibid., 34.

3 A. Sen, Development as Freedom (New York: Anchor, 1999).

4 M. Sheller and J. Urry, "The New Mobilities Paradigm," Environment and Planning A 38 (2006): 207-26.

5 T. Cresswell, "Toward a Politics of Mobility," in African Cities Reader: Mobilities and Fixtures, ed. Ntone Edjabe and Edgar Pieterse (Cape Town: Chimurenga and the African Centre for Cities, 2011), 160.

Bradley Rink is a human geographer, focusing his research and teaching at the University of the Western Cape (South Africa) on mobility-including migration-and urban placemaking. He is interested in the social aspects of moving in and through cities of the Global South, and the particular mobility strategies, moorings, and challenges that emerge. The author may be contacted at brink@uwc.ac.za.

\title{
Belonging: The Social Dynamics of Fitting In as Experienced by Hmong Refugees in Germany and Texas
}

\author{
n \\ Faith G. Nibbs \\ Durham, NC: Carolina Academic Press, 2014
}

$\mathrm{W}$ henever refugees and immigrants arrive in new places, there are pertinent questions about how they will adjust to living in their new society. These processes have been studied in terms of "integration, assimilation, and acculturation"-terms that have been critiqued as unidirectional and not as central to arrivals' experiences, such as the term belonging. In Belonging: The Social Dynamics of Fitting In as Experienced by Hmong
(C) Author(s), 2015. This open-access work is licensed under a Creative Commons Attribution-NonCommercial 4.0 International license.
Cette oeuvre en libre accès fait l'object d'une licence Creative Commons Attribution-NonCommercial 4.0 International. 
Refugees in Germany and Texas, based on her anthropology doctoral dissertation, Faith G. Nibbs explores Hmong refugees' "belonging" vis-à-vis mainstream society in their new countries, Hmong in their new locales, and Hmong throughout the diaspora.

Through ethnographic methods (with her English and German skills and help of Hmong translators), Nibbs has given us insight into the varied and complex nature of "belonging" through her exploration of social, political, cultural, economic, and historical contexts of Hmong refugee resettlement in Gammertingen, Schwaben, Germany (GG) and Dallas-Fort Worth, Texas, USA (DFW). Both locations had relatively small numbers of Hmong refugees during her study period-approximately 5 families in GG and 250 families in DFW.

To explore "belonging" vis-à-vis the new society, Nibbs illustrated interconnected processes by which resettlement program structures applied pressure on refugees, so they were "being made" into people who could fit into the new society; and whereby refugees' own agency engaged them in "making it" as people who made a place for themselves in the new location.

Nibbs explored the different structural events at national, state, and local levels to understand the societal forces of refugees "being made" into new citizens. Germany had an integrated program that connected people with local citizens, and provided one year of financial support so that people could learn the language before having to find employment. In contrast, Texas found locals who initially helped the refugees find apartments and jobs, with the goal that they be economically self-sufficient as quickly as possible (if not within two weeks). Years later, Nibbs described how refugees in both communities were economically selfsufficient, with all families having a wage-earner and the vast majority of families owning their own homes.

On the other side of these mainstream processes were refugees' actions of "making it." Nibbs asserted that people's "ingenuity and agency" shaped their lives, as they reacted to local situations and local resources, and as they utilized mainstream resources and resources within their own local ethnic group to be successful. This was the other half of "being made" - this was refugees' actions towards "making it."

Beyond economic status as a measure of "belonging," Nibbs looked into people's participation in the larger society. She discovered that people became citizens for security, so they could not be expelled, could travel without restriction, and could vote (although they did not run for office or participate in political processes). They did not become citizens in order to become Germans, or become Texans. Both GG and DFw Hmong expressed how their being Hmong was separate from their resident country; they had been Hmong in Laos, and now they were Hmong in Germany and Hmong in Texas.

To explore "belonging" in their local Hmong communities, Nibbs recounted the communities' interactions with each other and with new Hmong arrivals and then compared their similar and yet disparate experiences. For Hmong in both locations, the cultural values of kinship, maintaining face, and reciprocity were important dynamics as people adjusted and created new relationships that translated into their belonging with their local Hmong community. The role of religion was significant, as animist Hmong became Christian in order to fit in with other Hmong, not in order to fit in with their mainstream neighbours. In conclusion, people in each locale had created their own version of Hmong culture, so she asserts they "became" German Hmong or Texas Hmong, while still being Hmong in Germany and Hmong in Texas.

To explore "belonging" in the diasporic Hmong community, Nibbs investigated Hmong people's social connections with each other in the diaspora that occurred via modern technology and face to face, facilitated by modern transportation. The Internet allowed people to interact around important issues, such as videos that represented their shared history, discussions about changing cultural traditions (particularly funerals, weddings, and New Year's), and formations of Hmong political alliances and actions, and it facilitated their ability to find Hmong marriage partners. She described how these technologies illustrated as well as dictated (on the basis of differential power bases) to dispersed peoples elements of the diasporic identity. And she asserted that the diasporic identity was dynamically shaped by local people who contributed their sense of identify in return.

As a family physician working with Hmong in St. Paul, Minnesota, I appreciated Nibbs's in-depth examination of intertwined processes, but I was disappointed in two aspects. While she wrote that she hoped her findings would help policy-makers and professionals create "culturally sensitive" programs for refugees, she did not spell out the practical applications as she did the contributions to the literature. While her aim was to describe "belonging" and identity from Hmong people's experiences, she did not expand upon their personal emotional experiences or explore psychological and mental-health aspects of resettlement and the belonging processes. She quoted people saying they were Hmong "in their heart," by their "values," dress, language, food, rituals, and how they "raise their children." It would have been gratifying to me if she had expanded upon these aspects of identity and included emotional dimensions of "belonging" to her ethnography.
(C) Author(s), 2015. This open-access work is licensed under a Creative Commons Attribution-NonCommercial 4.0 International license.
Cette oeuvre en libre accès fait l'object d'une licence Creative Commons Attribution-NonCommercial 4.0 International. 
In conclusion, Dr. Nibbs has made several contributions to the anthropological and refugee studies literature on important questions of refugee resettlement, by exploring relevant and inter-related issues that influence refugees' "belonging" in relation to their new larger society, their own local ethnic group, and their diasporic ethnic group members, which readers will find insightful.
Kathleen A. Culhane-Pera is associate medical director and co-director of Community-Based Research at West Side Community Health Services, St. Paul, Minnesota. She is a family physician and medical anthropologist who has worked with Hmong in Minnesota since 1983 and in Thailand since 1989. She is co-editor of Healing by Heart: Clinical and Ethical Case Stories of Hmong Families and Western Clinicians. The author may be contacted at kathiecp@yahoo.com.

\title{
The Law of Refugee Status, 2nd edition
}

\author{
$\sim$ \\ James C. Hathaway and Michelle Foster \\ Cambridge: Cambridge University Press, 2014
}

$\mathrm{R}$ efugee law is unique. It is practised by few (those who do, tend to specialize), understood by fewer, yet is the constant subject of lawmakers as a means to manage and reflect public opinion.

Since refugee law is an international instrument that is moulded and shaped by individual signatory countries, it tends to develop in many directions, sometimes rationally and sometimes not. This makes a comprehensive, principled understanding quite difficult.

This is where The Law of Refugee Status, second edition, steps in to try to make sense of the development of the law since the first edition more than twenty years ago.

The first edition of this book, published in 1991, has been cited often. It built a clear understanding of refugee law over the last twenty years. It is a staple on the bookshelf of legal professionals in this area.

Overall, Hathaway and Foster have done an excellent job of updating and providing a substantially revised tool for those who practise, adjudicate, and legislate in refugee law. Ironically, I see many of my colleagues still citing the first edition, as if by deeply ingrained habit.

Where this text really shines is the clarity of making sense of otherwise complex concepts. For example-alienage-the chapter-starts with the sentence: "Only a person outside her own state can qualify as a Convention Refugee." That pretty much says it, and you can dig into the details from there, but you have a solid grasp of the concept right from the start.

Each chapter draws on the interpretations of international tribunals, such as the UN committee against torture and the Un Human Rights committee, regional tribunals such as the European Court of Human Rights, and the national courts of more than twenty countries. The book draws heavily on Canada, Australia, the United Kingdom, the United States, and Germany for guidance. This is truly an international perspective.

When the first edition has been cited with approval by various courts and tribunals, that is noted in the second edition. When courts and legislators have made advances, the second edition shows where and why.

I have practised refugee law in Canada since shortly after the first edition was published and have taught in this field for nine years. Despite my client-centred perspective, ultimately all refugee decisions must be sound and principled to all stakeholders. This book strives to describe the principles as interpreted around the world as its context. They show what is sound and principled.

Here is how the book is broken down.

First, the introduction. It is important and worth a careful read. It reminds us that this area of law derives from an international treaty that has been adopted by its signatory countries. It is not a law of convenience for signatory countries. These are rights that must be respected. It is a treaty that must, in law, be interpreted in good faith, in a manner that promotes its effectiveness, within a current social reality and contemporary legal context. That's the law of international treaty interpretation and application. Sometimes this is overlooked by courts and legislators.

Second, like in the first edition, the refugee definition is broken down into the constituent elements, and each gets its own chapter.

The five basic parts of the refugee definition from the first edition-alienage, well-founded fear, persecution, nexus, and cessation/exclusion-are now expanded into seven: alienage, well-founded fear, serious harm, state protection, nexus, cessation, and exclusion.

The first five describe who is included in the definition, and the last two say who is excluded. Each element has its
(C) Author(s), 2015. This open-access work is licensed under a Creative Commons Attribution-NonCommercial 4.0 International license.
Cette oeuvre en libre accès fait l'object d'une licence Creative Commons Attribution-NonCommercial 4.0 International. 
own in-depth chapter to provide a wealth of interpretive guidance.

Like with many texts that purport to provide a thorough treatment, you really put the details to the test only when you are required to apply the law to the facts before you. I have recently had the chance to put two of the chapters to the test because of recent profound changes in Canadian refugee law.

The change is to an element of refugee law called cessation. This means that once you no longer need refugee protection, it will cease. The legal test for cessation is that one either acts to show one no longer needs protection or one's country has now changed in ways that make it safe to return. While the basic legal tests are the same, now these tests are being applied to people who have also acquired permanent resident status in Canada.

In effect, when you no longer need refugee status, you are deemed to no longer need permanent resident status either. Quite simply, this does not appear to occur in any other refugee signatory country. The norm was that once permanent status is granted, there was no need to revisit the need for refugee protection. No other permanent residents in Canada have to constantly account for the basis of the original basis of the grant of permanent residence, but now refugees do.

What at first appeared rational, becomes, upon examination, a shell game. The only way I could begin to sort this out was to look at the big picture-and along came the second edition. This issue is covered exhaustively in chapters 6 and 7; I read and re-read them.
Chapter 6 revealed that this is an unprecedented change. Chapter 7 revealed that the change itself is unprincipled. These chapters together provided the tools to give guidance and structure in my submissions to the necessary tribunals in Canada. Frankly, no one understands the how or the why of these changes-not the refugee tribunal, not the courts, not my colleagues. Lawyers for the government are forced to justify it all by saying it is the will of Parliament (rationale not apparently required).

What this exercise in legal interpretation demonstrated for me is that refugee law is in constant flux in its application and interpretation-despite long-standing core principles and more than sixty years of application throughout the world.

When an unanswered question arises, the essential principles must be revisited.

This text is as worthy a place to start with the tough questions as with the easy ones.

In 1989, during his second year at Osgoode Hall Law School, Douglas Cannon was given the following advice from one of his professors: "Law is hard work, stressful, rewarding, frustrating, and, if you are lucky, you will be well paid. Only one of those features will keep you from burning out in five to seven years." Douglas has now been practising, teaching, and learning about immigration and refugee law for more than twenty years in Vancouver-because it is rewarding. The authormay be contacted at DCannon@elgincannon.com.

\section{Survival Migration: Failed Governance and the Crisis of Displacement Alexander Betts Ithaca: Cornell University Press, 2013}

\section{Humanitarian Crises and Migration: Causes, Consequences and Responses Edited by Susan F. Martin, Sanjula Weerasinghe, and Abbie Taylor New York: Routledge, 2014}

\section{Crisis and Migration: Critical Perspectives \\ Edited by Anna Lindley \\ New York: Routledge, 2014}

\section{Introduction}

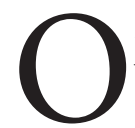
n 12 and 13 October 2015, as the world's attention was focused on the refugee crisis unfolding on Europe's borders, a meeting was convened in Geneva to consider how the world should respond to the growing instances of cross-border displacement resulting from disasters and the effects of climate change. This latest meeting of the Nansen Initiative heard compelling evidence of the scale of this form of displacement: 184 million people displaced by disaster per year between 2008 and 2014. That's one person every second. The meeting also produced some encouraging results: 111 states endorsed the recommendations on how to ensure protection for these displaced persons.
(C) Author(s), 2015. This open-access work is licensed under a

Creative Commons Attribution-NonCommercial 4.0 International license.
Cette oeuvre en libre accès fait l'object d'une licence Creative Commons Attribution-NonCommercial 4.0 International. 
The Geneva meetings marked a potentially important step in global discussions on how to address gaps in the global response to the millions of people every year who are displaced by natural disasters, such as floods, earthquakes, and droughts. While these forms of displacement are not new, it is argued that they are becoming more frequent and significant as a result of the effects of climate change. While the Office of the United Nations High Commissioner for Refugees (UNHCR) has had a policy on responding to displacement in the context of natural disasters since 2008, it is clear that neither the mandate nor the scale of this form of displacement can be fully addressed within the global refugee regime. As the UNHCR struggles to respond to the needs of some 60 million displaced persons in the world today - the highest level since the end of the Second World War-some estimates place the number of people displaced as a result of climate change as closer to 250 million by 2050.

In response to the scale of the challenge, the significance of current protection gaps, and the limitations of addressing this issue within current institutional frameworks, the Nansen Initiative was launched by Switzerland and Norway in 2012. It is a state-led process to produce a consensus among states on the standards by which future responses should be guided. The result could be a new set of global norms that may have a lasting impact on the rights of the displaced for many years to come.

\section{New Research on Crisis Migration}

It is within the context of this global policy process that we can more fully appreciate the timeliness of three recent books by respected scholars in the field of refugee and forced migration studies. Survival Migration by Alexander Betts draws on six case studies to understand if, when, and how states "stretch" the spirit of the global refugee regime to offer protection to individuals who flee to their countries for reasons that do not meet the standards established by the 1951 Convention relating to the Status of Refugees. Humanitarian Crises and Migration, edited by Susan Martin, Sanjula Weerasinghe, and Abbie Taylor, includes seventeen chapters from prominent scholars that examine the range of contexts in which mobility and immobility are associated with humanitarian crises and the diversity of populations affected. Crisis and Migration, edited by Anna Lindley, draws on a range of compelling case studies to problematize the assumption that human mobility constitutes a crisis, arguing for the need to treat both "crisis" and "migration" as complex processes rather than singular events. While they are not the first works to critically engage with the relationship between phenomena such as climate change and forced migration, these three books provide an important foundation for future research on these issues and raise challenging questions. Given the pace of policy discussions on these issues, it is important for the research community to engage with the questions raised by these recent books in a critical and meaningful way.

\section{Survival Migration}

Survival Migration makes at least two important contributions to these discussions. First, the book proposes the category of "survival migration," defined as individuals who are "outside their country of origin because of an existential threat for which they have no access to a domestic remedy or resolution" (4-5). By considering the core purpose of refugee protection, and following a reflection of new drivers of displacement such as environmental change, food insecurity, and state fragility, the book highlights "the range of people who have a human rights-based entitlement not to be returned to their country of origin, irrespective of whether they are refugees and of whether that right derives from international refugee law or international human rights law" (25). The book then usefully engages with potential critiques of this new approach, such as the risks associated with the proliferation of labels, the emphasis on those who cross international borders, and the semantics of the term survival. The treatment of these concepts and questions within a single chapter makes for a compelling argument-both within the context of the book and within wider debates about the limits of established refugee definitions.

The more significant contribution of the book, however, is its engagement with the limits of the current contours of the global refugee regime and its ability to "stretch" to ensure protection for new categories of forced migrants. Through the rich and detailed case studies of the responses of South Africa, Botswana, Angola, Tanzania, Kenya, and Yemen to "survival migrants," the book argues that regimes do not stretch to accommodate new categories of forced migrants because of the articulation of global norms. Instead, the book argues that regimes stretch, or do not stretch, largely as a result of national politics and the perceived interests of local elites. While we have known for some time that politics affects the quantity and quality of asylum afforded by states, Survival Migration moves this area of research forward by presenting a framework for identifying the range of domestic and international factors involved, thereby providing a basis for future comparative research on the implications of similar interests and processes in different states.

Implicit in Betts's argument, however, is a sense that the current regime can adapt to new forms of displacement and that "if the processes that shape implementation can be understood, then they can be influenced" (176). This suggests that responses to new forms of migration can more usefully begin by understanding how inclusion and
(C) Author(s), 2015. This open-access work is licensed under a

Creative Commons Attribution-NonCommercial 4.0 International license.
Cette oeuvre en libre accès fait l'object d'une licence Creative Commons Attribution-NonCommercial 4.0 International. 
adaptation have been possible in recent cases, and if similar preconditions can be encouraged elsewhere.

\section{Humanitarian Crises and Migration}

While the role of politics and interests in conditioning responses is echoed in Humanitarian Crises and Migration, the book's conclusions are less optimistic in the ability of current arrangements to adapt and the sufficiency of existing institutions. While the book outlines the range of norms and institutions that exist to respond to different forms of "crisis migration," the final chapter of the book concludes that "in some areas, existing governance structures adequately address the humanitarian challenge" while "in other areas, there are gaps that need to be filled" (363). Many of these gaps are to be found in the broader range of populations included in the analysis of the book, compared to Survival Migration. While "survival migrants" are those individuals who fled across an international border, Martin, Weerasinghe, and Taylor include in their analysis the needs of those who are displaced (both within states and across borders) as a result of crises, those who move in anticipation of a crisis, and populations who are trapped and are unable to move. This breadth of focus-on those who move both across borders and within countries, along with those who are not able to move-is analytically ambitious but effectively addressed by the first two chapters of the book.

The central focus of the book is to understand the relationship between migration and humanitarian crises, which the book defines as situations "in which there is a widespread threat to life, physical safety, health or basic subsistence that is beyond the coping capacity of individuals and communities in which they reside" (5). As the book then argues, this understanding challenges the forced-voluntary dichotomy that has been central to many of the policy and analytical efforts to characterize and classify instances of migration. In considering the applicability of this dichotomy to many recent instances of migration that have fallen outside existing frameworks, the book proposes the concept of "crisis migration" as a "deliberately broad" concept that seeks to engage with the "commonalities and differences in all movements across various crisis situations and the associated protection needs" of the populations concerned (11). In this way, the book describes "crisis migrants" as "all those who move and those who become trapped and are in need of relocation in the context of humanitarian crises" (12).

The book then proposes a framework for responding to the protection needs of related populations. At first, the framework seems overly ambitious, especially in light of Betts's characterization of the central role of interests in affording and denying protection. The rigour of the framework, however, becomes more apparent through the fifteen subsequent chapters. Indeed, the core of the volume comprises rich and detailed chapters by recognized experts on instances and forms of displacement. Jane McAdam's chapter provides a strong foundation for the book through its consideration of the challenges and opportunities presented by evolutions in international law and policy on new forms of displacement in recent years. Elizabeth Ferris's chapter on Haiti illustrates the challenges associated with overlapping drivers of displacement and immobility through intersecting humanitarian crises. Anna Lindley's chapter on Somalia problematizes the popular account of climate change and displacement by highlighting the role of state capacity and political conflict in mitigating such forces. Chapters by Roger Zetter and James Morrisey and by Koko Warner and Tamer Afifi draw on the most current research on environmental change and displacement to consider the limits of our current understandings of causation and the efficacy of responses to both mitigate displacement and respect the rights of those who are displaced. Richard Black and Michael Collyer's chapter on "trapped" populations presents a compelling critique of the assumptions of causation and mobility that have triggered most recent responses. And these are the contributions of but six of the chapters. Much is to be learned from a close reading of all chapters and the contribution they make to the overall argument of the book. In this way, one of the few gaps in an otherwise comprehensive text is the absence of a concluding chapter that revisits the case studies and reinforces the volume's central argument through their contributions.

Ultimately, the book identifies three categories of individuals with different protection needs. The first category comprises "individuals whose governments are willing and able to provide protection" (19). While some forms of external support may be necessary, the challenge here largely relates to ensuring that international standards are upheld in domestic contexts. The second category includes "individuals in situations where governments are willing but unable to provide adequate protection" (19). In these instances, the challenge involves generating the international support and assistance necessary to implement programs to enable the state to protect its citizens, and developing a common set of international standards to identify what those standards should be. Much more challenging is the third category, when "governments are unwilling to provide protection to their citizens or non-nationals on their territory" (20). While the book highlights many of the normative and institutional tools available to responding to these more challenging situations-ranging from the work of the un's Inter-Agency Standing Committee, the Responsibility to Protect, and, ultimately, the involvement of the UN Security Council-these situations remain the most problematic
(C) Author(s), 2015. This open-access work is licensed under a Creative Commons Attribution-NonCommercial 4.0 International license.
Cette oeuvre en libre accès fait l'object d'une licence Creative Commons Attribution-NonCommercial 4.0 International. 
because of the limited enforceability of these norms and the inconsistency of these institutions. Just as Betts highlights how the interests of local elites often determines the ability of a global regime to adapt in local contexts, the text highlights how greater agreement is required on how these global norms and institutions can and should be enacted in an effort to mobilize international action.

\section{Crisis and Migration}

The inherently political nature of these global norms and institutions, however, raises much broader questions about the distribution of power in the international system, and which actors are able to evoke existing norms and identify instances that warrant intervention, especially against the wishes of states that are the target of intervention. This is equally true in debates on the implementation of the norm of the Responsibility to Protect as it is in instances where states in the Global North may design and implement programs to contain forced migration in the Global South. Similar interests have arguably contributed to the fact that 86 per cent of the world's refugees are to be found in their regions of origin, and have motivated the kinds of restrictive responses to demands for entry currently unfolding in Europe. In such contexts, it becomes especially important to understand which actors have the legitimate authority to label situations as a "crisis" and implement particular responses.

As suggested by its title, Crisis and Migration: Critical Perspectives raises these questions and provides a set of analytical tools to more fully unpack the interests and motivations behind the deployment of certain labels and categorizations. The book challenges the assumption that instances of migration are inherently a crisis by taking "a critical look" at how crisis and migration are articulated "as lived experiences and as political constructs" (1). In this way the book mirrors critical thinking on the securitization of asylum by highlighting how the imprecise use of the term crisis permits a range of restrictive processes, many of which are justified as short-term responses to moments of crisis but become part of a more routine and regular pattern of behaviour by a range of actors. The explanation of this logic in the introductory chapter is especially helpful. The remainder of the book employs this critical approach to highlight the many assumptions, interests, and forces that have contributed to the construction of various "crises." Some of these interests have deep historical roots, such as colonial interests, while others are more contemporary, such as the downplaying of the situations in Somalia and Mexico by Northern states.

The volume then helpfully applies these lessons to a reconsideration of responses we have traditionally seen to identified instances of "crisis migration." Katy Long's chapter draws on border closures between Turkey and northern Iraq (1991), Macedonia and Kosovo (1999), and Kenya and Somalia (2007-11) to identify the interests implicated in the characterization of these situations in a way that justified restrictive responses. As "products of politically manufactured crisis" (170), Long argues that these cases highlight how the interests of certain actors produced these experiences and how we need to more fully consider how international responses to these instances can "prompt or permit action and the ways in which such exceptional crises are legitimized" (170). Likewise, Tania Kaiser's examination of the experience of Sudanese Acholi refugees in Uganda challenges our understanding of the meaning of "crisis" as it is "understood and experienced by different social actors" (199). By tracing responses to prolonged displacement over fifteen years and the role of social networks in mediating and marshalling these responses, Kaiser's chapter challenges many assumptions about the displacement experience, highlighting the "possibility of transformational effects" (199) and urging future research to challenge current categorizations while working to bring the individual and shared experiences of the displaced more fully and rigorously into our analysis.

Overall, the book makes an invaluable contribution to the literature by illustrating the interests that have motivated a range of actors to deploy the terms and categories of "crisis" and "migration" in particular ways, at particular moments, for particular reasons. This conclusion should not only encourage us to ask more probing questions of the interests inherent in current debates on a global response to "new" forms of migration, but also encourage researchers themselves to be more critically self-aware of the assumptions inherent in the terms we use.

\section{Foundations for Future Research}

It is in this way that we can appreciate the distinct contributions of each text for future research on the causes, consequences, and possible responses to forms of displacement that are now gaining prominence on the international policy agenda. More specifically, they raise at least three questions for future research.

First, what are the challenges and benefits of broadening our understanding of new categories of those in need of international protection? Given the deep historical roots of many contemporary situations, as highlighted by Lindley's volume, can we delineate between "survival migration," "crisis migration," and those who feel compelled to move more generally as a result of structural inequalities and the forces of globalization and global inequalities? To what extent can we continue to challenge the distinction between those who are forced to flee and those who choose to move?
(C) Author(s), 2015. This open-access work is licensed under a Creative Commons Attribution-NonCommercial 4.0 International license.
Cette oeuvre en libre accès fait l'object d'une licence Creative Commons Attribution-NonCommercial 4.0 International. 
Second, how can a more detailed and nuanced understanding of the interests of actors at the global and local levels contribute to our understanding of the range of possible responses? All three works shed important light on the role that politics and interests play in conditioning responses. While this has been an important element of research on the functioning of the global refugee regime in recent years, our engagement with recent discussions on new forms and categories of displacement can be usefully informed by a critical understanding of the diverse interests of the wide range of actors involved. This may be especially important in the discussion of new categories of individuals deemed to be in need of international protection and the types of responses that are to be encouraged.

Third, and more fundamentally, these works help us ask important questions about the evolution and continued coherence of the global refugee regime. To what extent does the notion of a single global regime for refugees remain analytically coherent or politically relevant? Do recent discussions undermine the claims to legitimacy of the regime, formalized by states in the aftermath of the Second World War, or represent another effort by states to dilute the significance and legitimacy of this regime?
These are but three questions provoked by a reading of the works by Betts, Martin, Weerasinghe, and Taylor, and Lindley. These are fundamental questions to be asked of the discipline of refugee and forced migration studies, and questions that go to the heart of ongoing global policy discussions. Recently 111 states agreed to new principles on the protection of individuals displaced across borders as a result of natural disasters and the effects of climate change. While this may seem at first like an encouraging development, recent research should encourage and enable us to engage more fully and critically with deeper questions about what this can and should mean for the rights and well-being of the millions of people who may be affected.

James Milner is associate professor, Department of Political Science, Carleton University, Ottawa. His research concentrates on the politics of the global refugee regime, global refugee policy, protracted refugee situations, and the politics of asylum in Africa. The author may be contacted at James.Milner@carleton .ca.
(C) Author(s), 2015. This open-access work is licensed under a

Creative Commons Attribution-NonCommercial 4.0 International license.
Cette oeuvre en libre accès fait l'object d'une licence Creative Commons Attribution-NonCommercial 4.0 International. 
(C) Author(s), 2015. This open-access work is licensed under a Creative Commons Attribution-NonCommercial 4.0 International license.
Cette oeuvre en libre accès fait l'object d'une licence Creative Commons Attribution-NonCommercial 4.0 International. 